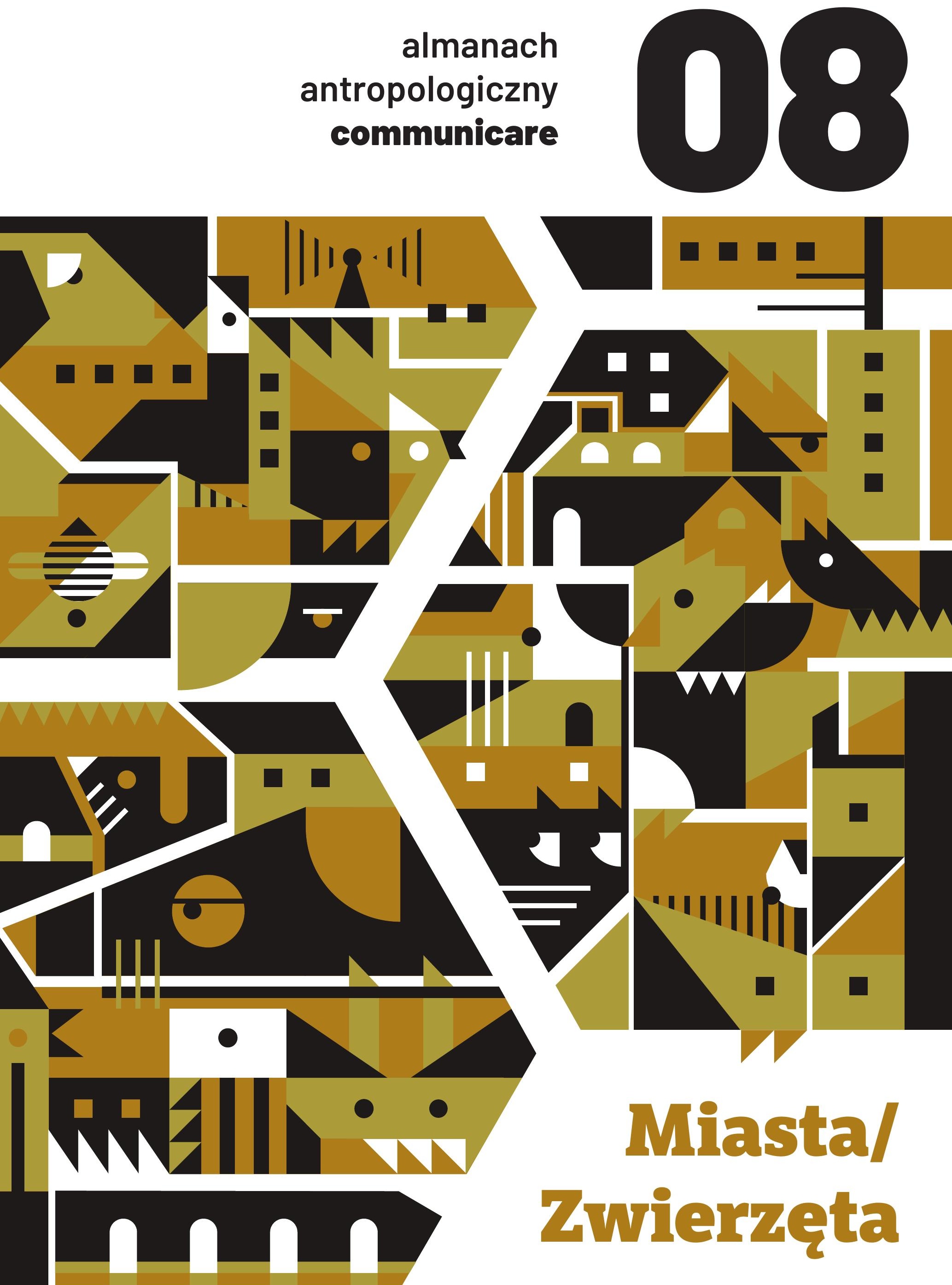




\section{Komitet redakcyjny}

Wojciech Dudzik

Grzegorz Godlewski

Agnieszka Karpowicz

Iwona Kurz

Włodzimierz Karol Pessel

Paweł Rodak

Poprzednie tomy „Almanachu Antropologicznego. Communicare”, przygotowane w serii opracowanej w Instytucie Kultury Polskiej Uniwersytetu Warszawskiego, zainicjowanej przez Andrzeja Mencwela:

t. 1: Internet

t. 2: Oralność/Piśmienność

t. 3: Słowo/Obraz

t. 4: Twórczość słowna / Literatura.

Performance, tekst, hipertekst

t. 5: Szkoła/Pismo

t. 6: Aktorka/Emancypacje

t. 7: Miasta/Awangardy 
almanach

antropologiczny communicare
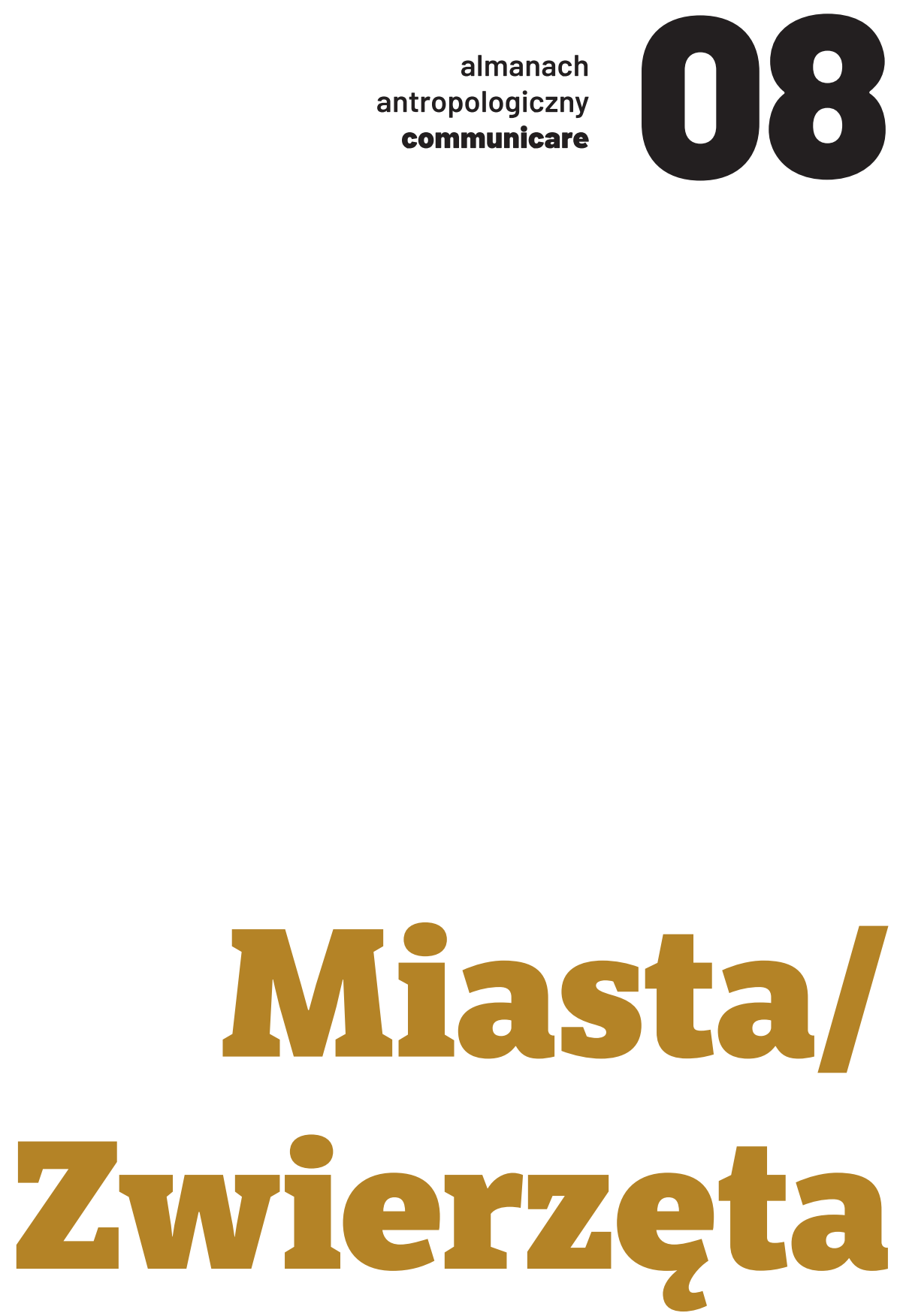

REDAKCJA TOMU

Anna Jaroszuk Igor Piotrowski Karolina Wróbel-Bardzik 


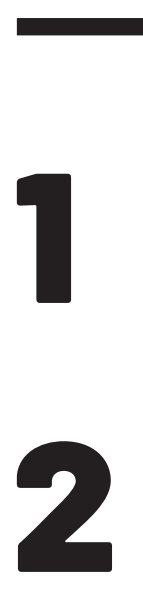

\section{Wstęp}

Anna Jaroszuk, Karolina Wróbel-Bardzik Miasta/Zwierzęta

\section{Z historii i teorii problemu}

Jennifer Wolch Anima urbis, przeł. Justyna Włodarczyk

Peter Atkins Zwierzęce nieczystości i utrapienia

w dziewiętnastowiecznym Londynie, przeł. Justyna Schollenberger

\section{Rozpoznania}

Karolina Wróbel-Bardzik Dystans i oddzielenie. Konie oraz zwierzęta hodowlane w Warszawie na przełomie XIX i XX wieku

Justyna Włodarczyk Parki są dla ludzi? Psy w przestrzeni miejskiej w USA, Wielkiej Brytanii i Polsce

\section{Analizy i interpretacje}

Aleksander Wójtowicz Gawron, czyli intruz w mieście

Anna Jaroszuk „Plaga i niewinne stworzenia” - psy w przestrzeni publicznej Warszawy na przełomie XIX i XX wieku

Joanna Gellner Zauważone! - zmiana stosunku do koni w Krakowie na przełomie XIX i XX wieku

Stephanie Weismann Odorogenne zwierzęta w międzywojennym

Lublinie, przeł. Sara Herczyńska

Michalina Augusiak Słoń a sprawa miejska. Ogród zoologiczny

w Warszawie i konflikty wokółnowoczesnej sfery publicznej (1872-1914)

Monika Żółkoś Owad i metropolia. Walki świerszczy w obserwacji uczestniczącej Hugh Rafflesa

Igor Piotrowski Osy zaraz po wojnie. Owady na miejskim marginesie:

realizm i widzialna obecność

Karolina Wróbel-Bardzik „Była to śmierć olbrzymia i liczna”.

Zwierzęta oraz bombardowanie Warszawy w czasie kampanii wrześniowej 1939 roku

\section{Recenzje i omówienia}

Justyna Schollenberger Niebezpieczne związki - Tora Holmberg

o miejskich zwierzętach

Sara Herczyńska Mleko, tężec i słoń Jumbo. Kanadyjskie zwierzęta miejskie

Zofia Jakubowicz-Prokop Polityki nie-ludzkiego miasta. The City Is More

Than Human Fredericka L. Browna 



\section{Anna Jaroszuk \\ Karolina Wróbel-Bardzik}

Miasta/Zwierzęta

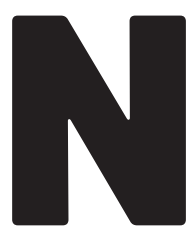

iniejszy tom Miasta/Zwierzęta stanowi próbę szerszego wprowadzenia w obręb polskiej humanistyki problematyki miejskich studiów nad zwierzętami i geografii zwierząt, rozwijanych coraz intensywniej w ciągu ostatnich kilkunastu lat w różnych ośrodkach, między innymi w Stanach Zjednoczonych, Wielkiej Brytanii i Kanadzie. Autorki i autorzy podjęli się opracowania tematu, który dotąd zarówno w polskich badaniach miejskich, jak i w studiach dotyczących relacji ludzko-zwierzęcych (human-animal studies) nie był podejmowany. W polskim obiegu akademickim wciąż brakuje publikacji, które prezentowałyby narzędzia tych nurtów badawczych oraz ich główne kierunki rozwoju, dlatego tom ten ma za zadanie przynajmniej częściowe wypełnienie owej luki. Wydaje się to tym istotniejsze, że obecność zwierząt w miastach stała się w ostatnich latach w Polsce przedmiotem ożywionych dyskusji pozakademickich, decyzji władz miejskich, przeobrażeń przestrzennych oraz ewoluujących praktyk społecznych. Ukazuje się również coraz więcej książek popularyzujących ten temat, przede wszystkim w perspektywie ustaleń nauk przyrodniczych ${ }^{1}$.

Publikacja składa się z czterech działów: Z historii i teorii problemu, Rozpoznania, Analizy i interpretacje oraz Recenzje i omówienia. Dział pierwszy zawiera przekłady kanonicznych już dla miejskich studiów nad zwierzętami i geografii zwierząt tekstów anglojęzycznych. Tłumaczenie tekstu Jennifer Wolch Anima urbis - autorstwa Justyny Włodarczyk, polskiej badaczki uznanej w środowisku międzynarodowym - przybliży polskiemu czytelnikowi nurt badań, jakim jest geografia zwierząt. Wolch przedstawia historię dziedziny oraz jej główne założenia, wskazując na możliwe kierunki rozwoju tego typu prac badawczych, które mogą się ogniskować wokół takich zagadnień jak: miejsca i przestrzenie zwierząt, zmiany praktyk miejskich związanych ze zwierzętami, negocjacje dotyczące obecności zwierząt w mieście, znaczenie urbanizacji, zarządzeń administracyjnych i aktywizmu lokalnego dla życia zwierząt.

Z kolei przekład artykułu Petera Atkinsa (z książki pod jego redakcją Animal Cities. Beastly Urban Histories) - autorstwa Justyny Schollenberger - stanowi przykład, jak można narzędzia miejskich studiów nad zwierzętami stosować w odniesieniu do materii historycznej. Jest to również jeden z kluczowych tekstów diagnozujących przemianę, jaka zaszła w dziewiętnastowiecznych miastach europejskich w stosunku do obecności w nich zwierząt. Atkins, przywołując liczne dokumenty i konteksty, opisuje procesy definiowania odzwierzęcego brudu i nieczystości oraz ich zwalczania poprzez budowę kanalizacji i usunięcie między innymi tak zwanych 
zwierząt hodowlanych z miasta na przykładzie dziewiętnastowiecznego Londynu. Pozycja ta może uchodzić za klasyczną w historycznych studiach miejskich nad zwierzętami².

Należy podkreślić, że w odniesieniu do przykładów zarówno zagranicznych, jak i rodzimych - polskich - autorzy i autorki kolejnych studiów przypadku w dziale Rozpoznania oraz Analizy i interpretacje posługują się narzędziami przedstawionymi w pierwszej części tomu. Inspirując się pracami głównie anglojęzycznymi, wydobywają specyfikę lokalnych - krakowskich, lubelskich, warszawskich czy wileńskich - zjawisk miejskich związanych ze zwierzętami. Przedmiotem tych analiz są praktyki, regulacje prawne, instytucje, rozwiązania architektoniczne i urbanistyczne, a także dyskursy i wyobrażenia decydujące o tym, które zwierzęta współtworzą miasta i w jaki sposób, oraz kształtujące relacje i interakcje między ludzkimi i nie-ludzkimi aktorami życia miejskiego. Badacze i badaczki poświęcają więc uwagę poszczególnym gatunkom i ich konkretnym przedstawicielom zarówno jako cielesnym, czującym i nierzadko mającym sprawczość istotom, jak i jako figurom symbolicznym oraz dyskursywnym. W zebranych studiach powracają również pytania o definicje miejskości, przede wszystkim w euroamerykańskim kręgu kulturowym w ciągu ostatnich dwustu lat, a zwłaszcza o to, jak koncepcje i sposoby organizacji miast w kontekście relacji ludzko-zwierzęcych zmieniły się pod wpływem przemian modernizacyjnych zapoczątkowanych w Europie i Stanach Zjednoczonych w XIX wieku.

Aleksander Wójtowicz z Uniwersytetu Marii Curie-Skłodowskiej ukazuje dzieje gawrona na ziemiach polskich - w tym w Lublinie i Wilnie - który do dziś znajduje się na granicy różnych kategorii służących do opisywania świata natury. W tym celu badacz analizuje zarówno literackie i językowe przykłady przywoływania tego ptaka, jak i historyczne pisma ornitologów polskich, w ciekawy sposób zestawiając dyskursywne i symboliczne losy gawrona z ewolucją jego zwyczajów gniazdowania. Podkreśla przy tym, jak ważne dla tej ptasiej populacji było i jest do dziś zwycięstwo idei higieniczno-estetycznych, które przesądziły o kształcie zmodernizowanych, nowoczesnych miast.

Stephanie Weismann z Uniwersytetu Wiedeńskiego w artykule Odorogenne zwierzęta w międzywojennym Lublinie bada, jak zwierzęta kształtowały sferę sensualną i afektywną miasta. Podążając za rozpoznaniami Petera Atkinsa dotyczącymi procesów przyczyniających się do rugowania zwierząt hodowlanych z miasta, sytuowanych po stronie tego, co wiejskie, analizuje dyskursy na temat nowoczesnego miasta w Europie Środkowo-Wschodniej na przykładzie Lublina w okresie Drugiej Rzeczypospolitej. O miejscu koni w Krakowie przełomu XIX i XX wieku pisze z kolei Joanna Gellner z Muzeum Historycznego Krakowa. Autorka podkreśla ich ogromną rolę w modernizacji miasta i w szczegółach opisuje to, w jakich warunkach musiały w trakcie tych przemian pracować. Docieka, kto i dlaczego zainteresował się losem krakowskich koni, wskazując jeszcze na inną niż higieniści siłę kształtującą nowoczesne miasta - towarzystwa opieki nad zwierzętami. Podobne zagadnienia na gruncie warszawskim w odniesieniu do koni oraz innych zwierząt hodowlanych podejmuje Karolina Wróbel-Bardzik, natomiast Anna Jaroszuk rekonstruuje interakcje między ludźmi i psami w przestrzeni publicznej Warszawy na przełomie XIX i XX wieku.

Michalina Augusiak śledzi dyskurs towarzyszący powstaniu i funkcjonowaniu nowoczesnego ogrodu zoologicznego w Warszawie w latach 20. XX wieku, wpisując te debaty w kontekst peryferyjnego usytuowania Polski na mapie dziewiętnastowiecznych i dwudziestowiecznych imperializmów, cywilizacyjnych tęsknot i kolonialnych kompleksów, ale również rywalizacji pomiędzy zaborcami. O współczesnym stosunku do obecności psów w przestrzeni miast amerykańskich, brytyjskich i polskich na przykładzie parków dla tych zwierząt pisze zaś Justyna Włodarczyk. W swoim studium porównawczym badaczka pokazuje, jak organizacja psich parków może odzwierciedlać inne, na przykład klasowe, napięcia społeczne. Z kolei Karolina Wróbel-Bardzik w tekście poświęconym bombardowanej Warszawie w czasie II wojny światowej przygląda się temu, jak stan wyjątkowy wpływał na relacje ludzi i zwierząt oraz kondycję tych ostatnich.

W prezentowanym tomie zebrano możliwie jak najwięcej odniesień do badań prowadzonych w dziedzinach miejskich studiów nad zwierzętami i geografii zwierząt w innych krajach. Do rozszerzenia wiedzy o tych nurtach badawczych przyczynią się niewątpliwie recenzje autorstwa Sary Herczyńskiej, Justyny Schollenberger oraz Zofii Jakubowicz-Prokop zamieszczone w ostatnim dziale publikacji. Teksty te przedstawiają trzy różne konteksty oraz ośrodki 
badawcze (w Kanadzie, Szwecji oraz Stanach Zjednoczonych - w Seattle), w bardzo niewielkim stopniu znane w Polsce. Tym ciekawsza wydaje się podjęta przez Justynę Schollenberger próba odniesienia pytań stawianych przez Torę Holmberg w książce Urban Animals. Crowding in Zoocities do warunków polskich. Autorka recenzji wskazuje również na paradoksalny brak odwołań w książce do zwierzęcego punktu widzenia, co - wbrew szlachetnym, nieantropocentrycznym intencjom badaczki - prowadzi do ich nieobecności czy uprzedmiotowienia.

Na uwagę zasługuje także to, że kontekst wykraczający poza euroamerykański krąg kulturowy staje się przedmiotem analizy w ramach przedstawianych studiów przypadku. Zadania takiego podejmuje się Monika Żółkoś z Uniwersytetu Gdańskiego w artykule Owad i metropolia. Walki świerszczy w obserwacji uczestniczącej Hugh Rafflesa. Badaczka, opisując widowiska i walki z udziałem zwierząt w Chinach, ukazuje względność kulturowych klasyfikacji świata zwierzęcego. Owady w mieście stały się również przedmiotem zainteresowania Igora Piotrowskiego w tekście Osy zaraz po wojnie traktującym o sposobach konceptualizacji ludzkiego doświadczania owadów wyrażonych w tekstach różnych rodzajów i gatunków (głównie na przykładzie Warszawy wieków XIX, XX i XXI).

Autorki i autorzy w odmienny sposób opowiadają o interakcjach międzygatunkowych w miastach, ale każdorazowo odsyłają do konkretnych zjawisk kulturowych. Nie tyle dokonują radykalnego przedefiniowania relacji ludzko-zwierzęcych, ile ukazują wzajemne zależności, złożoność oraz dynamikę ich przemian w przestrzeniach miejskich. W publikacji z jednej strony istotne jest odniesienie do różnorodnych kontekstów kulturowych, z drugiej - wydobycie lokalnej specyfiki przedstawianych zjawisk oraz jak najszersza prezentacja polskiej perspektywy uwzględniającej różne ośrodki miejskie. Mamy nadzieję, że tom przyczyni się do poszerzenia wiedzy na temat historycznej i współczesnej obecności zwierząt w miastach oraz relacji ludzko-zwierzęcych w tego typu przestrzeniach, a także teorii łączących badania miejskie i studia nad zwierzętami. Publikacja stanowić może również inspirację do namysłu nad kształtem stosunków między ludźmi i zwierzętami w miastach przyszłości oraz nad sposobami ich organizowania, zwłaszcza w kontekście dziedzictwa dziewiętnastowiecznych i dwudziestowiecznych ruchów modernizacyjnych.

\section{PRZYPISY}

1 Zob. m.in. M. Schilthuizen, Ewolucja w miejskiej dżungli, przeł. J. Wołk-Łaniewski, Łodź 2019; N. Johnson, Sekrety roślin i zwierzat w miejskiej dżungli, przeł. K. Markiewicz, Białystok 2017; A. Szaraniec, Warszawa dzika, Warszawa 2019.

2 W dziedzinie historycznych studiów miejskich nad zwierzetami równie ważna pozycja, która ukazała się niedawno, jest: C. Wischermann, A. Steinbrecher, P. Howell (red.), Animal History in the Modern City. Exploring Liminality, London 2018. 


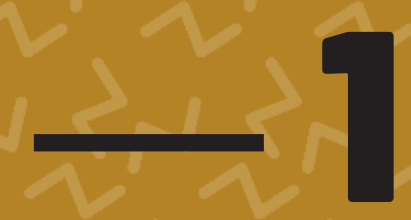

\section{$Z$ historii i teorii problemu}




\section{Jennifer Wolch}

\section{Anima urbis*}

\section{Wstęp}

Wiosną 2002 roku w Bibliotece Huntingtona w Los Angeles została zorganizowana konferencja pod tytułem Los Angeles: koszmar czy raj? Dzień, w którym się odbyła, był tak błękitny, spokojny i uroczy, że odpowiedź na zawarte w tytule pytanie zdawała się jednoznaczna, zwłaszcza wśród uczestników - naukowców, zamożnych przedstawicieli klasy średniej. Jednak po kilku godzinach ton spotkania przestał być beztroski, a konwersacja skierowała się w stronę zagadnienia: „Do kogo należy natura w mieście?”. Dyskusja skoncentrowała się na tym, w jaki sposób rasa i klasa społeczna determinują dostęp do parków miejskich. Mimo wybuchu intersubiektywnej wrażliwości tylko Lewis MacAdams - który nie zajmuje się akademickimi studiami miejskimi, ale jest poetą walczącym o odnowę rzeki Los Angeles - odważył się wspomnieć, że być może stworzenia czworonożne, beznożne i skrzydlate również potrzebują miejsca w mieście. Po raz kolejny koncepcja miasta jako środowiska naturalnego wyłącznie człowieka wygrała z bardziej inkluzywną wizją metropolii.

Jak sugerował MacAdams, w miastach roi się od ożywionych, czujących istot, które mają nogi, skrzydła, czułki i ogony - konkretnie, od zwierząt. Jednak mimo że podstawowym celem geografii jest wyjaśnianie relacji między społeczeństwem ludzkim a przyrodą, zwierzęta rzadko pojawiają się w miejskich badaniach geograficznych. Postrzegamy je jedynie jako części ekosystemów miejskich, surowce, które napędzają rozwój wielkich miast przemysłowych, albo symbole miejskiej kultury popularnej. Odzwierciedlając szersze trendy w geografii człowieka, zwłaszcza w ciągu ostatnich dwudziestu pięciu lat, geografia miasta w znacznej mierze ignorowała zwierzęta jako temat poważnej refleksji naukowej.

Od niedawna jednak niektórzy geografowie zaczęli brać pod uwagę zwierzęta, i to w sposób, który podkreśla ich podmiotowość, sprawczość, a także ich wartość użytkową oraz symboliczną. Przyczyny wyłonienia się tego nowego nurtu są różnorodne - częściowo jest to efekt rosnącej świadomości ich niedoli, zwłaszcza tak zwanych zwierząt mięsnych [food animals], hodowanych w warunkach przemysłowych, oraz zwierząt zagrożonych utratą naturalnych siedlisk i zanieczyszczeniem środowiska, jak również niedawnych odkryć w dziedzinie biotechnologii, 
które przybliżają możliwość powszechnego wykorzystania zwierząt jako części zamiennych ciała [człowieka]. Dodatkowo nowe podejścia do etyki i teorii społecznej zacierają granicę między człowiekiem a zwierzęciem, ujawniają, w jaki sposób więzi i konflikty na linii człowiek-zwierzę kształtują [ludzkie] zdrowie oraz praktyki codzienne; ujęcia te kontekstualizują także większą rolę zwierząt w nowoczesności - jako mimetycznego odzwierciedlenia relacji kultura-natura oraz samego kapitału przemysłowego ${ }^{1}$.

W artykule tym chciałabym poświęcić uwagę kwestii zwierząt w mieście. Moim celem jest zachęcenie geografów do włączenia świata zwierzęcego w badania nad urbanizacją oraz zasugerowanie, że wyobrażenie sobie anima urbis - oddechu, życia, duszy i ducha miasta jako ucieleśnionych w jego życiu zwierzęcym - może być ważne nie tylko ze względów intelektualnych, lecz także z powodów ekologicznych i moralnych. [...]

\section{Trendy w geografii zwierząt w XX wieku}

Moda na geografię zwierząt jako subdyscyplinę pojawiała się okresowo w XX wieku; jednak dopiero pod sam koniec stulecia zainteresowanie zwierzętami oraz badaniami im poświęconymi wyraźnie wzrosło. W pierwszej połowie XX wieku geografowie skupiali się na nich albo z perspektywy zoogeograficznej zorientowanej na przestrzeń, wzory i relacje przestrzenne, albo z punktu widzenia kulturowej geografii zwierząt, zwracając uwagę na miejsca, regiony i krajobrazy. Ich motywacja miała w znacznej mierze charakter środowiskowy. Oba te podejścia straciły na popularności i przestały się liczyć pod koniec pierwszej połowy XX wieku, gdy badania zoogeograficzne zostały przejęte przez działy biologii, a tradycyjna ekologia kulturowa znalazła się pod ostrzałem i została wyparta przez bardziej społeczne podejścia teoretyczne. W latach 70. XX wieku terminu „geografia zwierząt” nie można było odnaleźć w opracowaniach geograficznych. Mimo to pod wpływem ruchów społecznych dotyczących zwierząt, środowiska oraz prądów intelektualnych, które zwróciły uwagę naukowców na grupy marginalizowane - w tym zwierzęta - przed końcem stulecia stały się one po raz kolejny przedmiotem badań geograficznych.

$[\ldots]$

W pierwszej połowie XX wieku geografia zwierząt była aktywną, choć niewielką częścią dyscypliny. W jej ramach można było wyraźnie wyodrębnić dwa podejścia, które odzwierciedlały coraz szerszy rozdźwięk między geografią fizyczną a geografią człowieka: zoogeografię, skupiającą się głównie na przestrzennym rozmieszczeniu gatunków zwierząt, zakorzenioną w geografii fizycznej, zoologii i ekologii; oraz zorientowaną kulturowo geografię zwierząt, która koncentrowała się na procesach udomowienia i była związana z geografią człowieka oraz naukami społecznymi.

\section{[...]}

W latach 90. XX wieku zainteresowanie zwierzętami zostało rozbudzone na nowo. Zaczęto prowadzić nowe badania w zakresie zoogeografii² zainspirowane nowymi koncepcjami systemów informacji geograficznej (GIS) oraz teledetekcji, jak również odkryciami z zakresu geomorfologii. Co więcej - i jest to główny przedmiot zainteresowania w tym artykule - styczność geografii człowieka z teorią społeczną, kulturoznawstwem, niektórymi naukami przyrodniczymi oraz etyką środowiskową zaowocowała nowymi przedsięwzięciami badawczymi w obrębie kulturowej geografii zwierząt. Także książka Yi-Fu Tuana Dominance and Affection [Dominacja i czułość] ${ }^{3}$, która ujawniła relacje władzy związane z trzymaniem zwierząt domowych oraz podobieństwo tych stosunków do innych form dominacji, skierowała uwagę niektórych geografów na zwierzęta. W ostatniej dekadzie XX wieku opublikowano kilka tematycznych numerów czasopism oraz zredagowano parę tomów na ten temat ${ }^{4}$. Tego rodzaju wysiłki zapoczątkowały falę badań, które ponownie zaczęto określać mianem geografii zwierząt.

Co pobudziło ponowne zainteresowanie kulturową geografią zwierząt? Jednego z czynników należy szukać w szerszym kontekście społecznym: rozwój silnych ruchów ekologicznych w latach 70. i 80. XX wieku zaowocował powstaniem wielu nowych organizacji działających na rzecz zwierząt, takich jak PETA (Ludzie na rzecz Etycznego Traktowania Zwierząt), Front Wyzwolenia Zwierząt, Fund for Animals i Greenpeace. Najbardziej radykalne z tych grup odrzucały 
dominację ludzi nad planetą i zwierzętami oraz zarysowywały wyraźne paralele: między rasizmem, seksizmem i „szowinizmem gatunkowym” [speciesism]; między niewolnictwem, opresją postkolonialną i niewolą zwierząt; między Holokaustem, przemysłową hodowlą zwierząt i laboratoriami przeprowadzającymi eksperymenty na zwierzętach.

Obok kontekstu społecznego i aktywizmu związanego ze zwierzętami i środowiskiem naturalnym ważnym czynnikiem było zainteresowanie zwierzętami wyrażone w latach 80 . XX wieku przez teoretyków społecznych, w znacznej mierze pod wpływem nowych koncepcji wypracowanych przez feminizm, postmodernizm i poststrukturalizm, teorię postkolonialną i krytyczną teorię rasy. Jednym z efektów było ponowne przemyślenie aspektów kulturowych i ich wagi („zwrot kulturowy”). Nagle takie filmy jak Babe - świnka z klasą czy Uciekające kurczaki zaczęły jawić się jako ważne reprezentacje - a także krytyka relacji człowiek-zwierzę, a nie tylko hollywoodzkie, łatwe w odbiorze produkcje. Kolejnym rezultatem było poszerzenie koncepcji podmiotowości osobowej. Teoretycy społeczni zwracali uwagę na rozszerzanie definicji podmiotu oraz uwzględnianie podmiotowości mnogich, mieszanych i dynamicznych. Koncepcja klasycznego podmiotu uniwersalnego została odrzucona, dzięki czemu powstała przestrzeń, w której można było wziąć pod uwagę

Czerpiq̨c z nowych koncepcji kultury, natury i podmiotowości, geografowie zwierzq̨ rozpoczęli badania nad ich rolq w społecznej konstrukcji kultury, tożsamości indywidualnej, jak również zbiorowej, nad granica człowiek-zwierzę i jej niestabilnościq̨ oraz nad samą zwierzęcą tożsamościq i sprawczością. podmiotowość zwierzęcą

Ta możliwość została wzmocniona badaniami z zakresu psychologii kognitywnej, etologii, ekologii krajobrazu, biologii konserwatorskiej, które ujawniły złożoność zwierzęcych umysłów i zachowań; nagle okazało się, że nie tylko ludzie i zwierzęta człekokształtne charakteryzują się skomplikowanymi umiejętnościami kognitywnymi, jak również zachowaniami kulturowymi ${ }^{6}$. Inżynieria genetyczna, klonowanie i ksenotransplantacje jednocześnie kwestionowały granice między maszynami, zwierzętami oraz ludźmi, urzeczywistniając wizję świata „cyborgów”. Oba rodzaje badań podważały utrzymujący się długo stereotyp „głupich zwierząt”, który służył podtrzymaniu ludzkiej tożsamości i pozycji na szczycie tego, co postrzegano jako hierarchię istot. Razem z „nową” historią środowiskową - praktykowaną przez Donalda Worstera8 i Williama Cronona ${ }^{9}$, którzy przekonująco nakłaniali do włączenia natury w próby zrozumienia urbanizacjiprądy te doprowadziły do powstania nowych koncepcji sprawczej przyrody.

Pod koniec XX wieku geografowie z różnych środowisk intelektualnych, razem z aktywistami, teoretykami społecznymi i historykami środowiskowymi, zaczęli opowiadać się za potrzebą uznania podmiotowości zwierząt, a także wyjścia poza ogólniki w paradygmacie natura-społeczeństwo i przyjrzeniem się bliżej interakcjom ludzko-zwierzęcym po to, by odnowić geograficzne rozumienie świata.

\section{Zwierzęta w mieście}

Przekonanie, że miasta są wyłączną domeną ludzi, jest powszechne, zwłaszcza w środowisku akademickim. Chociaż istnieje silna tradycja badań z zakresu miejskiej geografii politycznej, społecznej i gospodarczej, praktycznie nie ma miejskiej ekologii kulturowej czy biogeografii, od których można by wyprowadzić badania relacji ludzko-zwierzęcych w mieście. 
Przykładowo, szkoła chicagowska ignorowała zwierzęta (oraz rośliny) mimo przywłaszczenia sobie otwarcie ekologicznego języka.

Dostrzeżenie przyrody i zwierząt w mieście ma jednak niezaprzeczalną wagę. Jak przekonuje Daniel Botkin: „Jeśli nie przyznamy, że miasto pozostaje częścią środowiska i jest z niego stworzone, z dzikiej natury wilka i łosia, to ta natura, o której myślimy, że jest naturalna, nie będzie mogła przetrwać, a nawet nasze dalsze przetrwanie na planecie stanie pod znakiem zapytania"10. To rozpoznanie zainspirowało niedawne badania dotyczące geografii zwierząt skupione właśnie na mieście. Próby ożywienia tego typu badań miejskich w ciągu ostatniej dekady zwracały uwagę na to, w jaki sposób zwierzęta kształtują tożsamość i podmiotowość, na ich rolę i formowanie krajobrazu miejskiego oraz ewolucję i dylematy, które pojawiają się, kiedy pozwolimy, by zwierzęta miały wpływ na to, jak myślimy o mieście.

\section{Tożsamość i podmiotowość miejska}

Film Medal dla miss (2000) w zabawny sposób sparodiował słynną wystawę psów rasowych Westminster organizowaną w nowojorskiej hali Madison Square Garden. Każdy, kto widział ten film albo samą wystawę, nie zaprzeczy, że niektóre zwierzęta są blisko związane ze stereotypowymi tożsamościami miejskimi: podmiejska biała biedota, miejskie pary gejowskie, eleganckie i neurotyczne pary DINK (podwójna pensja, zero dzieci), tak jak inne z wiejskimi chłopakami, którzy lubią rozprawiać o psach myśliwskich ${ }^{11}$. Co więcej, w filmie psy wzięły sprawy w - jak można powiedzieć - swoje łapy, wkradając się w łaski swoich treserów oraz „opierając" się ludzkiej dominacji przez - w jednym przypadku - ugryzienie sędziego!

Czerpiąc z nowych koncepcji kultury, natury i podmiotowości, geografowie zwierząt rozpoczęli badania nad ich rolą w społecznej konstrukcji kultury, tożsamości indywidualnej, jak również zbiorowej, nad granicą człowiek-zwierzę i jej niestabilnością oraz nad samą zwierzęcą tożsamością i sprawczością ${ }^{12}$. Tylko kilku z nich podjęło kwestie tożsamości i podmiotowości w kontekście miejskim, jednak te nieliczne prace ujawniają, że obszar ten wymaga dalszego zgłębienia. Pod wpływem teorii postkolonialnej oraz krytycznej teorii rasy, które podkreśliły zależności między rasą, płcią kulturową i przedstawieniami „zwierzęcości”, geografowie zwierząt starali się zrozumieć ich rolę w kształtowaniu różnorodnych tożsamości przyjmowanych przez mieszkańców miast bądź im przypisywanych. Mogą one mieć związek z okresami historycznymi, miejscami geograficznymi lub wspólnotami wyobrażonymi, takimi jak narody, a także tożsamościami rasowymi/etnicznymi, kulturowymi lub genderowymi. Chociaż rozróżnienie między człowiekiem i zwierzęciem jest powszechnie zrozumiałe, granica ta przesuwa się w czasie i przestrzeni. Wynikiem jest dynamicznie zmieniający się, ale właściwy konkretnemu miejscu asamblaż zwierząt, wartościowanych i wykorzystywanych według usankcjonowanych kodów, które są coraz częściej kwestionowane w warunkach globalizacji i kształtowania miast na świecie.

Przykładowo, Kay Anderson ${ }^{13}$ przeprowadziła kulturową krytykę miejskiego zoo w Adelaide, analizując je jako instytucję, która tworzy różne ludzkie strategie udomawiania, mitologizowania i estetyzowania świata zwierząt i jednocześnie ugruntowuje tożsamość narodową mieszkańców tego miasta. Przez konstruowanie natury i zwierząt praktyki w zoo wzmacniały i legitymizowały australijską tożsamość kolonialną, naturalizowały władzę kolonialną i ucisk stosowany wobec rdzennych mieszkańców oraz umacniały genderowe i rasowe podstawy granicy człowiek-zwierzę. Badając wyodrębnienie się typowo miejskiej tożsamości w wiktoriańskiej Anglii, Chris Philo ${ }^{14}$ argumentował, że zwierzęta odgrywały ważną rolę w rozdzieleniu miejskich i wiejskich standardów przyzwoitości, obyczajności publicznej, akceptowalnych zachowań seksualnych, a także norm współczucia. Konstruowanie nowego miejskiego porządku - i odróżnienie go od wiejskich stereotypów - wymagało usunięcia z miast targów zwierząt rzeźnych i ubojni, takich jak Smithfield w Londynie. Zmuszały one cywilizowanych mieszkańców miast do bycia świadkami seksualnych zachowań zwierząt w drodze na targ, wystawiały ich delikatne zmysły na przemoc występującą w handlu zwierzętami i w rzeźni, stwarzały ryzyko zepsucia moralnego związanego z obcowaniem z poganiaczami bydła, którzy byli postrzegani przez reformatorów z klasy średniej jako skłonni do pijaństwa i ekscesów 
seksualnych. W efekcie targi mięsa i rzeźnie zostały z miast usunięte, co wzmocniło tożsamości miejskie jako zdefiniowane w opozycji do obszarów wiejskich, zamieszkanych przez zezwierzęconych ludzi i zwierzęta.

Opracowanie Philipa Howella ${ }^{15}$ na temat kradzieży psów w wiktoriańskim Londynie przedstawia zarówno te zwierzęta, jak i kobiety z klasy średniej jako ofiary patriarchalnego społeczeństwa, skazane na niewolę w domu i narażone na kontakt z mężczyznami z klasy niższej, z brudnym światem handlu i niebezpieczeństw czyhających w najbiedniejszych dzielnicach miasta. Odwołując się do satyrycznego tekstu Virginii Woolf o kradzieży psa Elizabeth Barrett, napisanego z punktu widzenia samego psa, Howell zarysowuje polityczną geografię kradzieży tych czworonogów, która charakteryzowała się antagonizmami klasowymi, wykorzystywaniem bogatych przez biednych i silnym zakorzenieniem w procesach „udomowienia” - tak psów, jak kobiet, ograniczanych wiktoriańskimi ideałami kobiecości, uległością wobec władzy mężczyzn i przynależnością do mieszczańskiego zacisza domowego. Relacje genderowe i zwierzęta są również tematem przewodnim analizy Van Stipriaana i Kearnsa ${ }^{16}$ dotyczącej billboardów jako ważnego czynnika środowiska zbudowanego [built environment], który kształtuje rozumienie płci i lokalnej kultury miejskiej. Badacze opisują sprawę kontrowersyjnej kampanii Królewskiego Nowozelandzkiego Towarzystwa Zapobiegania Okrucieństwu wobec Zwierząt promującej sterylizację zwierząt domowych. Billboardy w Auckland przedstawiały psa ubranego w kobiecą perukę, seksowne okulary, spódniczkę z falbankami i szpilki, umalowanego szminką i palącego papierosa, a towarzyszący rysunkowi slogan nawoływał: „Stop seksualizacji suk” [ang. De-sex your bitch]. Van Stipriaan i Kearns argumentują, że kampania i kontrowersje z nią związane destabilizowały relacje człowiek-zwierzę i podkreślały genderowe aspekty prezentacji zwierząt w kulturze popularnej - tym samym sugerując, że w mieście nie tylko są one obecne cieleśnie, lecz także odgrywają istotne role symboliczne w formowaniu kultury lokalnej.

Za podstawę mając teorię postkolonialną i krytyczną teorię rasy, inni badacze brali pod uwagę zwierzęta, aby zrozumieć dynamikę relacji rasowych w kulturowo różnorodnych miastach świata w warunkach globalizacji ${ }^{17}$. Dzisiaj, kiedy międzynarodowe migracje fizycznie zbliżają ludzi z różnych kultur, „nieprzystające do danego miejsca” [out-of-place] praktyki związane za zwierzętami mogą zostać odczytane jako transgresywne przekraczanie granic gatunkowych. Badając podejście do zwierząt kobiet mieszkających w dużym amerykańskim mieście i pochodzących z różnych grup rasowych/etnicznych oraz rozmaitych tradycji kulturowych, Marcie Griffith razem z zespołem badaczy ${ }^{18}$ odkryła wśród Filipinek tolerancję wobec jedzenia psiego mięsa. Zdawała się ona odzwierciedlać ich własne doświadczenie jako grupy zmarginalizowanej w społeczeństwie amerykańskim oraz wrażliwość na dyskryminację na podstawie kultury i koloru skóry. Respondentki pochodzenia filipińskiego obawiały się potępić grupy, których praktyki związane ze zwierzętami - choć dla nich obce i wzbudzające odrazę - były zakorzenione w innej kulturze, zamiast potępienia przyjmując postawę relatywizmu kulturowego.

Praktyki dotyczące zwierząt i jednocześnie powiązane z rasą/etnicznością mogą odzwierciedlać lub reprodukować miejskie układy rasowe. Pytane o swoje podejście do zwierząt, afroamerykańskie mieszkanki centrów miast często dzieliły świat zwierzęcy na trzy segmenty: ,jedzenie”, „domowi ulubieńcy” oraz „dzikie zwierzęta”. Zwierzęta zakwalifikowane do kategorii „jedzenie” były niezbędne do przeżycia, a ludzie musieli zdystansować się wobec ich przykrego losu. Domowi ulubieńcy i dzikie zwierzęta wymagały współczucia - ludzie powinni pomagać dzikim zwierzętom w trudnej sytuacji, tak samo jak powinni pomagać innym ludziom niezależnie od ich koloru skóry, co wskazywało na solidarność ze zwierzętami jako braćmi ze względu na marginalizację ${ }^{19}$.

Zwierzęta mogą również stać się łącznikiem z dawną tożsamością, tym samym łagodząc szok wywołany przez nowe, miejskie środowisko; mogą także odegrać rolę w procesie asymilacji. Dla imigrantek pochodzenia latynoamerykańskiego hodowla zwierząt takich jak kury w miejskich ogródkach była początkowo sposobem na podtrzymanie związku z wiejskim krajobrazem, który opuściły. Jednak z czasem kultura domowych ulubieńców i łącząca się z nią asymilacja stały się dominującą formą interakcji ze zwierzętami ${ }^{20}$. Kiedy zwierzęta dawniej trzymane w oborze czy ogródku są zapraszane do domu, tradycyjne granice między nimi a ludźmi zostają zachwiane. 
A co z podmiotowością zwierząt? Sarah Whatmore i Lorraine Thorne ${ }^{21}$, zainspirowane w pewnej mierze teorią aktora-sieci, postulowały, by wziąć pod uwagę sprawczość zwierząt. Podobnie jak Tim Ingold ${ }^{22}$ autorki sugerowały, że zwierzęta są „obcymi ludźmi” podobnymi do marginalizowanych grup ludzkich. W zbliżony sposób Philo ${ }^{23}$ proponował, by postrzegać zwierzęta jako przypominające zmarginalizowane, wykluczone społecznie osoby [...].

Jednak ani Whatmore, ani Thorne, ani Philo, ani też inni geografowie zwierząt nie analizowali sposobu myślenia i zachowań zwierząt po to, by lepiej zrozumieć ich podmiotowość i to, jak postrzegają ludzi. Jedynym wyjątkiem był „eksperyment myślowy” przeprowadzony przez Andreę Gulla ${ }^{24}$, który dogłębnie przestudiował literaturę naukową dotyczącą środowiska życia i zachowań pumy, aby ocenić, jak zwierzęta te odbierają ludzi. Czy rzeczywiście - jak sugerował jeden z ekspertów - postrzegają one dziecko jako małą świnkę do zjedzenia? Jak, i czy w ogóle, zmienił się stosunek pumy do człowieka w obliczu urbanizacji wkraczającej w środowisko tych zwierząt?

Ta strategia - polegająca na konceptualizacji tego, co zwierzęta myślą czy czują - jest obarczona różnymi trudnościami (wrócę do nich później w tym artykule), do których można zaliczyć brak wystarczającej wiedzy naukowej oraz pokusę nadmiernej antropomorfizacji. Jednak prace tego typu próbują również przekroczyć sferę spekulacji, by prowadzić do nawiązania relacji ze zwierzętami na ich zasadach, aby lepiej zrozumieć zwierzęce interakcje z ludźmi, zwłaszcza w kontekście przemian tych stosunków pod presją urbanizacji.

\section{Zwierzęta i tworzenie miejskich przestrzeni}

Zwierzęta grają kluczową rolę w tworzeniu miejsc i krajobrazów. To spostrzeżenie zostało dobitnie uwypuklone, kiedy w okresie prezydentury Billa Clintona praktycznie cały metropolitalny obszar Seattle został uznany za siedlisko krytyczne [critical habitat] łososia. Wprowadzenie stanu wyjątkowego wzbudziło wiele kontrowersji, ale również ujawniło, że łososie są symbolem, głównym elementem w kreowaniu tożsamości północnego zachodu USA, w szczególności miasta Seattle. Chodziło częściowo o kwestie ekonomiczne - wizerunek ryby przyciąga rzesze turystów, którzy przybywają z różnych stron, by wydawać tam swoje dolary. Niektórzy z nich nawet wędkują. W wielu dzielnicach i domach w mieście mieszkańcy sami pracowali nad przywracaniem strumieni, a także miejsc tarła do stanu pierwotnego, starając się choćby w małej skali - sprawić, by miasto było bezpieczne dla łososi. Nie powinno więc dziwić, iż w związku z rozporządzeniem administracji Clintona przedstawiciele władz miasta stwierdzili, że „wzrost ekonomiczny równa się ratowaniu łososia”, a mieszkańcy tłumnie demonstrowali, trzymając transparenty z napisami: „Co dobre dla łososi, dobre i dla ludzi”

Tego rodzaju zdarzenia oraz akademickie dyskusje dotyczące społecznej konstrukcji krajobrazu i miejsc skierowały uwagę geografów w stronę zwierząt i sieci, w które są one włączone, mając wpływ na kształt konkretnych miejsc, regionów i krajobrazów. Pojawiająca się w akademickich badaniach - prowadzonych przede wszystkim przez „nowych” geografów kulturowych ${ }^{26}$ - koncepcja, że zwierzęta mogą odgrywać istotną rolę w tworzeniu miejsc, była związana z rozpoznaniem, iż natura, kultura i podmiotowość są ucieleśnione w krajobrazie. Ci awangardowi badacze korzystali z narzędzi poststrukturalizmu, teorii dyskursu i dekonstrukcji, aby postrzegać krajobraz nie jako wytwór realistycznej „natury” czy enigmatycznej „grupy kulturowej”, ale jako „tekst” skomponowany ze znaków i symboli, których hegemoniczne odczytanie zarówno odtwarza, jak i reprodukuje te relacje władzy, wiedzy i dyskursu, jakie pierwotnie je stworzyły. Jednocześnie promowali oni alternatywne odczytania krajobrazu przez ludzi marginalizowanych/wykorzystywanych ze względu na płeć, rasę, klasę społeczną i orientację seksualną (kategorie, które często są „naturalizowane” i „animalizowane” przez patriarchalne czy kolonialne władze) ${ }^{27}$.

Takie inicjatywy miały jednak za punkt wyjścia wewnętrznie sprzeczne założenie - tworząc dyskursywną przestrzeń dla zwierząt, krytykowano koncepcję niedyskursywnej i zewnętrznej przyrody, której częścią mogłyby być zwierzęta lub w której mogłyby być aktywne. Dla wielu ekologów zaangażowanych politycznie, teoretyków praw zwierząt, ekofeministek i aktywistów takie poglądy zdawały się kwestionować żywotność świata ${ }^{28}$. Co więcej, denaturalizowanie natury 
i traktowanie miejsc geograficznych jako produktów kulturowych neguje sprawstwo przyrody, a zwłaszcza zwierząt. To „wykreślanie” [writing out] natury stało się katalizatorem ożywionych debat z „nowymi” historykami środowiska, takimi jak Worster i Cronon, którzy próbowali wykazać sprawczość natury ${ }^{29}$. Ta debata z kolei przyczyniła się do przemyślenia roli zwierząt w tworzeniu miejsc, regionów i krajobrazów ${ }^{30}$.

W kontekście miejskim badania skupiły się na znaczeniach związanych z oglądaniem zwierząt w miejscach publicznych (konkretnie w ogrodach zoologicznych); na tym, w jaki sposób (nie)obecność zwierząt prowadzi do specyficznego postrzegania dzielnic w mieście, na tworzeniu miejsc poświęconych wyłącznie zwierzętom w wyniku działań społecznych i prób odtworzenia siedlisk oraz na dynamice obrzeży miast, gdzie ludzie i zwierzęta dzielą się przestrzenią. Na przykład Anderson, pisząc: „[...] jeśli zoo jest «przestrzenią», ogród zoologiczny w Adelaide jest «miejscem»", stawiała ogólną tezę, że miejskie ogrody zoologiczne są kluczowymi miejscami w kulturowej konstrukcji natury, natomiast dziewiętnastowieczne zoo w Adelaide propagowało kolonialne i narodowe tożsamości przez konstrukcję krajobrazu. Podobnie Philo ${ }^{31}$ i Howell ${ }^{32}$ eksplorowali dziewiętnastowieczny Londyn, skupiając się na miejscach (nie)obecności zwierząt i na tym, jak ich interakcje z ludźmi mogą kreować szczególne krajobrazy miejskie i przyczyniać się do tworzenia symboliki krajobrazu.

Bardziej współczesne przykłady ukazują złożoność przestrzennych hierarchii ludzko-zwierzęcych w mieście i niejednoznaczność stosunku jego ludzkich mieszkańców do przejawów natury oraz cywilizacji w konkretnej przestrzeni. Na przykład Andrea Gaynor ${ }^{33}$ omawiała próby wykluczenia przez władze miasta Perth zwierząt gospodarskich, takich jak kurczaki, kozy i świnie (niegdyś popularnych w australijskich przydomowych ogródkach), z obszarów o zabudowie mieszkaniowej. Wykorzystując plany zagospodarowania przestrzennego, urzędnicy miejscy starali się zwiększyć higieniczność miasta, by przyciągnąć zamożniejszych mieszkańców i zmienić stosunek do tego miejsca. W trakcie ponownego ustalania porządku przestrzennego uprzywilejowano jedynie zwierzęta należące do konsumpcyjnego stylu życia klasy średniej zachęcano do trzymania domowych ulubieńców - kosztem relacji typowych dla klasy pracującej, koncentrujących się wokół produkcji (hodowanie zwierząt zarówno w celu wymiany gotówkowej, jak i dostarczenia pożywienia). Tymi działaniami zarządzający miastem wywołali konflikty i przyczynili się do utraty tożsamości przez wielu mieszkańców niezamożnych dzielnic, odmieniając charakter ich okolicy.

W innym badaniu dotyczącym tego, dlaczego niektóre zwierzęta są uznawane za niepożądane na obszarach miejskich, Huw Griffiths, Ingrid Poulter i David Sibley ${ }^{34}$ potraktowali koty wolno żyjące [feral] w mieście Hull jako zmarginalizowaną grupę społeczną mieszkającą w granicach miasta. Badali przy tym reakcje ludzi na nie w kontekście ludzkich koncepcji właściwej organizacji przestrzeni miejskiej. Analiza ujawniła, że niektórzy mieszkańcy odbierali miejsca związane z kotami wolno żyjącymi jako niepokojące i budzące odrazę, podczas gdy inni widzieli je jako bezpieczne schronienie zagrożonej dzikiej natury. Reakcje ludzi na skupiska kotów wolno żyjących pozostawały w związku z ich społecznymi wyobrażeniami na temat środowiska zbudowanego. Postrzegali oni przestrzenie tych zwierząt jako niezgodne z charakterem miasta lub odwrotnie - jako akceptowalne elementy krajobrazu miejskiego - i wzmacniali wyobrażenia kotów wolno żyjących jako faktycznie dzikich lub jako udomowionych „uciekinierów”, przyczyniając się do powstawania miejskich konfliktów społecznych.

Społeczna aktywność lokalna może prowadzić do stworzenia nowych, bardziej sformalizowanych przestrzeni miejskich projektowanych z myślą o zwierzętach i więzi na linii człowiek-zwierzę. Przykładem na to jest miejski ruch parków dla psów w USA. Mimo początkowych kontrowersji, jakie wywoływały wybiegi dla psów, są one obecnie standardową częścią systemu parków miejskich - pierwsze powstawały w wyniku wzmożonych wysiłków aktywistów. Jennifer Wolch i Stacy Rowe ${ }^{35}$ udokumentowały, w jaki sposób zdegradowany miejski park został przejęty z rąk narkomanów i prostytutek przez nieformalną grupę właścicieli psów, którzy zainwestowali w jego renowację i poprawę bezpieczeństwa, wykorzystując obecność dużych, biegających (wbrew przepisom) luzem psów, aby ograniczać mniej pożądane formy użytkowania tego terenu. Paradoksalnie, kiedy park stał się bardziej atrakcyjny, okoliczni mieszkańcy zgłaszali chęć korzystania z tej przestrzeni, ale przeciwstawiali się swobodnie biegającym czworonogom, przedstawiając konflikt interesów jako psy kontra dzieci „psy kontra dzieci”. Właścicielom psów 
udało się częściowo wygrać, normalizując ich pozycję jako pełnoprawnych członków amerykańskich rodzin i społeczności miejskich. Przywołany park jest w tej chwili miejscem zarówno dla ludzi, jak i dla zwierząt, pozostając przestrzenią działań oddolnych realizowanych w sferze zarządzania parkami oraz terenami rekreacyjnymi.

Wywodzące się z ekologii miejskiej próby przywracania siedlisk dzikich zwierząt, sprowadzenia ich z powrotem do miasta również ujawniają rozbieżne koncepcje dotyczące zwierząt i dzikości w mieście oraz kwestii, co tego typu działania mogą oznaczać dla dominacji człowieka. [...]

Złożoność ludzko-zwierzęcych hierarchii przestrzennych jest najlepiej widoczna na obszarach granicznych między miastem a terenami dzikimi w regionach metropolitalnych. Tam w planach zagospodarowania przestrzennego często wyznaczane są odpowiednie obszary dla ludzi i zwierząt, jednak podziały tak jasne na papierze okazują się znacznie bardziej skomplikowane $\mathrm{w}$ praktyce. Jak pisze Mike Davis: „Na mapach i planach zagospodarowania przestrzennego [...] granica między «zagospodarowanym» i «niezagospodarowanym» jest nakreślona jako linia prosta. Na papierze wyraźne granice oddzielają również parki, rezerwaty i oficjalnie chronione obszary dzikie. W rzeczywistości przenikanie się obszarów miejskich i dzikich jest znacznie bardziej złożo-

Jeśli sprawiedliwość społeczna i środowiskowa zostanie w końcu rozszerzona, tak by obejmowała również sprawiedliwość dla zwierzq̨t, pojawiq się pytania, jak dalece radykalną demokracje miejska jesteśmy sobie w stanie wyobrazić lub z jaką możemy poradzić sobie w praktyce.

ne"36. Nawet założenie, że

urbanizacja na obrzeżach miast jest odwrotnie proporcjonalna do działań służących zachowaniu bioróżnorodności, pozostaje często błędne, ponieważ tereny te nierzadko charakteryzują się zaskakującą różnorodnością zarówno rodzimych, jak i egzotycznych zwierząt oraz roślin, a niektóre gatunki rozwijają się doskonale w mozaice środowiskowej granic metropolii - przynajmniej przez jakiś czas, dopóki nie rozmnożą się tak bardzo, by zostać zaliczone do kategorii „szkodników”.

Davis śledzi historię interakcji ludzi z dzikimi zwierzętami w południowej Kalifornii, charakteryzując je jako „niekończący się łańcuch rzezi i wymierania” ${ }^{37}$, w którym brutalne dziewiętnastowieczne praktyki ranczerskie, polowanie i rybołówstwo w celach zarobkowych oraz ciągłe „ograniczanie” liczby drapieżników doprowadziły do zniszczenia większości naturalnych zasobów i dziedzictwa regionu na skutek urbanizacji. Zwierzęta były szczególnie ważnym elementem mechanizmu napędzającego rozwój gospodarczy Kalifornii w okresie gorączki złota; liczne pogłowie bydła spowodowało wówczas katastrofę ekologiczną - znaczną erozję, inwazję egzotycznych gatunków oraz wypieranie rodzimych gatunków zwierząt preriowych. Łowiectwo komercyjne, mające zaspokoić potrzeby miejskich rynków, zostało w końcu ukrócone nie tylko ze względu na to, że liczba przedstawicieli wytrzebianych gatunków drastycznie się zmniejszyła, lecz także z powodu stawianych przez elity żądań ochrony zwierząt dla osób uprawiających myślistwo rekreacyjnie. To z kolei doprowadziło do stworzenia obejmującego cały stan programu zarządzania zwierzyną łowną, którego elementem były również próby ograniczenia liczby drapieżników na nowo zagospodarowanych obszarach obrzeży miast, oficjalnie przeznaczonych dla ludzi.

[...] W szerszej perspektywie geografowie badali także, w jaki sposób konflikty dotyczące relacji ludzie-zwierzęta [...] łączą się z gwałtownym rozwojem miast i w efekcie kształtują całe obszary metropolitalne poprzez plany ochrony gatunków oraz inne tego typu inicjatywy. W południowej Kalifornii, gdzie w latach 1982-1997 ponad 160000 hektarów ziemi zostało zajętych 
przez rozrastające się miasta, Thomas Feldman i Andrew Jonas ${ }^{38}$ wykorzystali teorię reżimu wzrostu miejskiego, aby zrozumieć ewolucję konfliktów dotyczących wykorzystania ziemi i podejmowania decyzji przez właścicieli nieruchomości, organizacje ekologiczne, władze lokalne i koalicje na rzecz rozwoju miejskiego w hrabstwie Riverside. Badania, inspirowane ustawą o ochronie zagrożonych gatunków ${ }^{39}$, zaowocowały praktycznym ćwiczeniem z planowania regionalnego na szeroką skalę - dzięki temu niektóre obszary hrabstwa oznaczono jako tereny przeznaczone pod zabudowę, a inne jako środowiska chronione. Stephanie Pincetl ${ }^{40}$ opisała zaś, jak konkretne lokalne reżimy wzrostu odpowiadają wytycznym ustawy o ochronie zagrożonych gatunków, przyczyniając się do tworzenia zintegrowanych planów zagospodarowania przestrzennego, transportu i ochrony siedlisk, co z kolei skłania właścicieli gruntów do potajemnego zabijania przedstawicieli zagrożonych gatunków. Wszystkie te badania zarysowują, w jaki sposób relacje z niektórymi zwierzętami, skodyfikowane prawnie, zostają wpisane w dynamikę urbanizacji w systemie kapitalistycznym, kształtując zasięg metropolii, wzory relacji ludzie-dzikie zwierzęta oraz szanse na przetrwanie nie-ludzkich mieszkańców.

\section{Zwierzęta jako kompas moralny miasta}

W 2002 roku w Kalifornii głośnym echem odbiła się sensacyjna historia kobiety, mieszkanki budynku wielorodzinnego w San Francisco, postawionej przed sądem z powodu „morderstwa” sąsiadki, popełnionego przez psa oskarżonej - przedstawiciela rasy dog kanaryjski o (poniekąd proroczym) imieniu „Bane”41. Ta dziwaczna, typowo kalifornijska historia obfitowała w szokujące odniesienia do świata nielegalnych walk psów, Bractwa Aryjskiego i seksu międzygatunkowego. Oczywiście zwierzęta w średniowieczu stawały przed sądem za popełnione przez siebie przestępstwa ${ }^{42}$, a Bane został już ukarany śmiercią (chociaż nigdy przed sądem nie stanął); jednak był to pierwszy przypadek od dawna, kiedy człowiek został bezpośrednio pociągnięty do odpowiedzialności za szał zabijania, w który wpadło jego zwierzę ${ }^{43}$. Jest jasne, że moralny kompas relacji ludzi oraz zwierząt w mieście ulega przesunięciom i - tak jak wiele innych aspektów życia w nim - podlega ciągłym negocjacjom.

Literatura dotycząca etyki środowiskowej, głębokiej ekologii i praw zwierząt z końca XX wieku przyniosła dużą polaryzację, jeśli chodzi o podmiotowość zwierząt, ich status moralny oraz to, w jaki sposób ludzie powinni odnosić się do świata nie-ludzkiego ${ }^{44}$. Zdaje się jednak, że z tych tarć wyłoniła się jeszcze bardziej postmodernistyczna etyka środowiskowa, która skłania do traktowania nie-ludzkiej podmiotowości poważnie, podkreśla niepełność i usytuowanie wiedzy, współzależność istot żywych i środowiska naturalnego oraz natury i kultury. Takie podejście otwiera więcej kontekstualnych dróg prowadzących do podejmowania etycznych wyborów ${ }^{45}$.

Podążając za tymi debatami, niektórzy geografowie zwierząt zadawali pytania, jakie jest miejsce zwierząt w krajobrazie moralnym, kiedy zacznie się kwestionować ludzką dominację oraz przekonanie o braku podmiotowości i sprawczości zwierząt. Zastanawiając się nad tymi pytaniami, badali kwestię prawa dostępu zwierząt do pożywienia ${ }^{46}$; etyczne perspektywy spożywania mięsa ${ }^{47}$; etykę ruchów na rzecz ochrony zwierzą ${ }^{48}$; rolę zwierząt w tworzeniu „moralnych geografii" [moral geographies] konkretnych miejsc i regionów ${ }^{49}$; konflikty między perspektywą praw zwierząt i etyką, która wyłania się ze zrozumienia tego, że sama struktura gospodarki kapitalistycznej jest powodem ich cierpienia ${ }^{50}$, oraz bardziej ogólne paradygmaty myślenia o geograficznie usytuowanych interakcjach człowiek-zwierzę ${ }^{51}$.

Nurt ten jednak dopiero zaczął się rozwijać - stosunkowo niedawno zaczęliśmy myśleć o wyborach moralnych, których dokonujemy, tworząc miasta i mieszkając w nich, oraz o tym, co te wybory oznaczają dla zwierząt. Dzieje się tak mimo wielu problemów moralnych charakteryzujących życie w miastach: eutanazji zwierząt domowych; eksterminacji tych, które nie zostały uznane za gatunki zagrożone; destrukcji środowisk będącej wynikiem rozrostu obszaru miejskiego; zanieczyszczenia miejskich dróg wodnych i zawłaszczania ekosystemów, aby realizować miejskie style życia, oparte na konsumpcji. Jeśli przyznamy zwierzętom podmiotowość, sprawczość i - być może - nawet zdolność do tworzenia kultury, w jaki sposób będziemy decydować o ich prawie do przeżycia w mieście? Do jakich przestrzeni miejskich powinien nas skierować wewnętrzny kompas moralny - do domów, firm, na ulice, do parków i otwartych 
przestrzeni, restauracji i supermarketów? Konsekwencje wypracowania naszego moralnego spojrzenia w miejskich przestrzeniach są ogromne. Przykładowo, prawo federalne ustala standardy czystości wody dla wszystkich dróg wodnych, ale są to standardy zaprojektowane dla ludzi, a co jest tolerowane przez człowieka, niekoniecznie będzie tolerowane przez - chociażby - żaby. Czy to oznacza, że amerykańska Agencja Ochrony Przyrody powinna wyznaczać standardy czystości wody odpowiednie dla płazów? Odpowiedź najprawdopodobniej brzmi: tak co pociąga za sobą potrzebę szeroko zakrojonych badań i, koniec końców, regulacji prawnych.

Jeśli sprawiedliwość społeczna i środowiskowa zostanie w końcu rozszerzona, tak by obejmowała również sprawiedliwość dla zwierząt, pojawią się pytania, jak dalece radykalną demokrację miejską jesteśmy sobie w stanie wyobrazić lub z jaką możemy poradzić sobie w praktyce. W badaniach ankietowych z 2002 roku zapytano mieszkańców dużego, różnorodnego regionu metropolitalnego o ich tolerancję wobec kilku kontrowersyjnych praktyk związanych ze zwierzętami, takich jak walki kogutów, spożywanie psiego mięsa, rodeo itp.52 Okazało się, że tolerancja - jedna z miar etycznych stanowisk respondentów - była dość niska, ale różniła się znacznie między różnymi grupami rasowymi/etnicznymi, co z kolei wskazuje, że ustalenie jednorodnych norm etycznych dotyczących interakcji ludzi i zwierząt jest bardzo trudne, nawet w mieście, które charakteryzuje duża wymiana kulturowych norm i wartości ${ }^{53}$. Do tej pory nie zastanawiano się nad tym, w jaki sposób zwierzęta mogą być uwzględniane w trakcie podejmowania takich decyzji.

W moich własnych badaniach - biorąc pod uwagę moralność, zwierzęta i miasta - próbowałam konceptualizować sposoby rozgrywania granicy człowiek-zwierzę przez etyczne praktyki planowania miasta i życia w mieście. Ważną kwestią jest tutaj podmiotowość zwierząt: kiedy porzucimy sztywną granicę, która powoduje, że podmiot-człowiek znajduje się po jednej stronie, a przedmiot-zwierzę po drugiej, stajemy się zobligowani, by włączyć zwierzęta w swój namysł etyczny oraz w codzienne praktyki. Chociaż wyzwania związane z wykonaniem tego zadania, zwłaszcza na poziomie ekonomii politycznej, są ogromne, przed nami jest jeszcze trudniejszy zestaw pytań. Czego chcą zwierzęta? Czy kiedykolwiek możemy to wiedzieć? Klasyczny argument przeciwko możliwości udzielenia odpowiedzi na to pytanie został przedstawiony przez filozofa Thomasa Nagela ${ }^{54}$, który zapytał: jak to jest być nietoperzem? Nagel uznał, że nie jest możliwe, by człowiek się tego dowiedział. Ale czy rzeczywiście nie da się „myśleć jak nietoperz”? Najprawdopodobniej nigdy nie poznamy jego najskrytszych pragnień. Zwykle bardzo trudno przychodzi nam zrozumienie najskrytszych pragnień ludzi, zwłaszcza tych, którzy różnią się od nas fundamentalnie, na przykład płcią kulturową. Być może ludzie nie są więc zdolni dosłownie „myśleć jak nietoperz”; mimo to zamiast nihilistycznego relatywizmu czy wyparcia różnic między ludźmi i zwierzętami odpowiedzią może być dostrzeżenie, że ludzie oraz zwierzęta są wplątani w społeczne relacje i sieci (zarówno ludzkie, jak i nie-ludzkie), od których zależy ich społeczny dobrostan.

To spostrzeżenie pozwala nam uznać zarówno pokrewieństwa, jak i różnice, bo tożsamości są przecież definiowane przez to, jak bardzo jesteśmy od siebie inni, ale także w jaki sposób jesteśmy powiązani z innymi. Ludzie powinni poznać, choćby częściowo, zwierzęta, z którymi współistnieją, aby podtrzymywać sieci połączeń oraz etykę szacunku i wzajemności, opieki i przyjaźni. Oczywistym wyzwaniem jest wymyślenie, w jaki sposób sentymenty te można przekuć na praktykę i rzeczywiście projektować miasta w sposób, który wyraża to, że zwierzęta są ważne; w skrócie: w jaki sposób przekształcić metropolis w zoopolis - miejsce mieszkania ludzi i zwierząt.

\section{Re-animując miasto}

Obecnie geografia przoduje w badaniu historycznych i kulturowych konstrukcji relacji ludzi i nie-ludzi, genderowych i rasowych wymiarów tych stosunków, a także ich ekonomicznego uwikłania. Mimo to, jeśli chodzi o relacje ludzi i zwierząt w mieście, jest jeszcze dużo pracy do wykonania, jeśli rzeczywiście chcemy re-animować [re-animate] miasto zarówno w teorii, jak i w praktyce.

Jak jednak osiągnąć ten cel? Jednym z możliwych punktów wyjścia jest poziom teoretyczny, z naciskiem na przemyślenie teorii miejskiej i destabilizację jej antropocentrycznych tradycji, stworzenie nowej ekologii politycznej ludzi i zwierząt w mieście. Celem tego rodzaju teorii jest 
zbliżenie różnorodnych dyskursów, od teorii społecznej do ekologii dzikich zwierząt, i zachęcanie do empirycznych badań z wykorzystaniem szerokiego zestawu metod. Na zestaw ten powinny się składać nie tylko metody, które są już używane przez geografów miasta, lecz także nowe sposoby rozumienia wzorów oraz zachowań zwierząt, pochodzące z etnografii ${ }^{55}$ i historii miejskiej ${ }^{56}$, jak również z badań zoogeograficznych rozwijających się dzięki nowym technologiom oraz próbom scalenia geografii człowieka i geografii fizycznej (na przykład wykorzystujących systemy informacji geograficznej GIS i teledetekcji, geografii czasu) ${ }^{57}$. Taki plan badawczy miałby pomóc w osiągnięciu czterech głównych celów ${ }^{58}$.

\section{- Zrozumienie urbanizacji z perspektywy jej znaczenia dla życia zwierzęcego.}

Geografowie miasta (między innymi) wypracowali bogatą literaturę teoretyczną na temat urbanizacji, wykorzystującą między innymi ekonomię polityczną ${ }^{59}$, teorię postmodernistyczną ${ }^{60}$, analizę reżimów miejskich ${ }^{61}$, badania nad segregacją rasową, płciową oraz segregacją mieszkaniową ${ }^{62}$, badania dysproporcji podatkowych ${ }^{63}$ i krytyczną teorię rasy ${ }^{64}$. Mimo to przyroda miejska rzadko pojawia się w tego rodzaju pracach, a dotychczasowe badania w dziedzinie miejskiej geografii zwierząt nie wypełniły jeszcze luki między makroskalą - badaniami rozwoju miast, planowania ochrony środowisk i gatunków zagrożonych - a badaniami w mikroskali, dotyczącymi roli konkretnych gatunków (zwierząt gospodarskich, drapieżnych i towarzyszących) w rozwoju miejskim $^{65}$. Koncepcje zaczerpnięte z nowej historii środowiskowej, analizy zwierzęcych łańcuchów towarowych [commodity chain analysis], opisanie lokalnych relacji natura-państwo i kulturoznawcze badania ruchów mających na celu ochronę przestrzeni miejskiej dla zwierząt mogłyby pomóc rozszerzyć plan badań dotyczących urbanizacji tak, by obejmowały również rolę zwierząt.

- Prześledzenie, w jaki sposób i dlaczego podejścia do zwierząt i praktyki z nimi związane oraz wzory interakcji ludzi i zwierząt zmieniają się w czasie i przestrzeni.

Wiemy bardzo mało na temat ewolucji takich interakcji, ale badania relacji ludzi i zwierząt obecnie rozwijają się dynamicznie, a geografowie zwierząt - co odnotowano powyżej - przyczyniają się do tego analizami, jak zwierzęta i przedstawienia zwierząt kształtują tożsamość miejską i tożsamość jednostkową, jak współwywołują konflikty społeczne, jaki mają udział w stygmatyzacji rasowej pewnych populacji miejskich, na przykład imigrantów ${ }^{66}$. Dalsze analizy mogłyby być znacznie szerzej zakrojone; mogłyby też dotyczyć większych obszarów i dłuższych okresów, łącząc analizy interakcji ludzi i zwierząt z ewolucją naturokultur w mieście, sieciami aktorów miejskich skupionymi wokół produktów pochodzenia zwierzęcego oraz wpływem globalizacji, i zmieniać przy tym stosunek do środowiska miejskiego.

- Zbadanie, w jaki sposób ekologia zwierząt jest tworzona przez dyskurs nauki, dyskurs społeczny i siły ekonomii politycznej.

Możliwości współegzystowania zwierząt w mieście są silnie kształtowane przez dyskursy mające związek z ekologią jako dziedziną nauki, zagadnieniem dobrostanu i prawami zwierząt, ochroną środowiska i prawami własności w mieście. Geografowie zwierząt przyczynili się do lepszego zrozumienia tej dynamiki ${ }^{67}$, ale wiele jeszcze można osiągnąć, dokładnie analizując założenia miejskiej biogeografii z perspektywy nauk społecznych i feminizmu. Można na przykład badać politykę kluczowych planów i studiów miejskich dotyczących bioróżnorodności, a także wypracować bardziej złożoną polityczną ekologię miasta, która bierze pod uwagę rolę dyskursu w kształtowaniu ochrony środowiska i odtwarzaniu siedlisk, zarządzaniu populacjami dzikich zwierząt itp.

- Zrozumienie, w jaki sposób relacje ludzi i zwierząt są w praktyce kształtowane przez plany administracyjne, aktywizm lokalny i sprawczość zwierząt.

Większość badań nad zarządzaniem terenami miejskimi i praktykami planowania miejskiego (nawet tych, które mają na celu zarządzanie środowiskiem naturalnym) rzadko bierze 
pod uwagę zwierzęta, z wyjątkiem przedstawicieli zagrożonych gatunków ${ }^{68}$. A zatem, jak pokazuje Lorraine Thorne ${ }^{69}$, dzikie zwierzęta nabierają wartości dzięki swojej śmierci i wymieraniu. Podobnie planowanie miejskie oraz ekologia krajobrazu zwykle nie są zgrane z potrzebami i pragnieniami zwierząt mieszkających w miastach. Coraz częściej powstają jednak nowe ruchy społeczne, których celem jest działanie na rzecz zwierząt miejskich i przyrody - stworzenie dosłownej oraz dyskursywnej przestrzeni dla zwierząt w mieście ${ }^{70}$. Rzadkością są badania, w których podejmuje się próbę wyobrażenia sobie miasta z punktu widzenia zwierzęcia ${ }^{71}$. Problemowi temu można by zaradzić dzięki badaniom etnograficznym dotyczącym zwierząt w mieście.

Przykładem, jak takie ożywcze, transgatunkowe podejście do zrozumienia miasta i urbanizacji może wpływać na praktykę, jest przemyślenie tego, jaką rolę rzeka Los Angeles odgrywa w kształtowaniu gospodarczego, politycznego, społecznego i naturalnego środowiska. Próba odpowiedzi na pytania o funkcję tej jednej rzeki kieruje naszą uwagę w stronę zwierząt.

Urbanizacja Los Angeles i jej podstawy gospodarcze były początkowo zależne od rzeki Los Angeles, jej wód i naturalnych zasobów. Rzeka przyciągała ryby i inne dzikie zwierzęta - w niektórych okresach stawała się siedliskiem tak dużej liczby wędrownych ptaków, że niebo nad nią ciemniało w ciągu dnia ${ }^{72}$. Jaką rolę i dla kogo odgrywały te zwierzęta w tworzeniu gospodarczego bogactwa regionu? W jaki sposób machina gospodarczego rozwoju miasta i stanu wpływała na kolejne decyzje dotyczące rzeki - czy celem było jedynie wykorzystanie jej jako wygodnego miejsca do spuszczania ścieków?

Zwierzęta żyjące dzięki rzece w końcu zniknęły w wyniku komercyjnych polowań; industrializacja oraz wzrost liczebny populacji spowodowały jej zanieczyszczenie; budowa infrastruktury ułatwiającej transport zniszczyła rosnące na brzegu drzewa; nabrzeża zostały uregulowane, wyprostowane i uzbrojone przez Korpus Inżynieryjny Armii USA, co radykalnie zmieniło charakter rzeki, która obecnie należy do najbardziej zdenaturalizowanych w Stanach $^{73}$. Jakie podejścia do natury i dzikich zwierząt dominowały w okresie, kiedy zdecydowano o uregulowaniu koryta rzeki? Dlaczego ideologia „kontroli natury” przeważała na tym obszarze? ${ }^{74}$ Jakie kulturowe i polityczne przesunięcia doprowadziły do tego, że pod koniec XX wieku wizerunek rzeki Los Angeles stał się ponownie tak ważny ${ }^{75}$ i obecnie często jest postrzegana jako duchowe serce miasta?

Dzisiaj odnowa środowiska rzeki przerodziła się w misję przywrócenia przyrody miastu, które najbardziej słynie z niekontrolowanego rozwoju zabudowy miejskiej oraz z zanieczyszczenia środowiska, a także w misję zbliżenia ludzi pochodzących z różnych środowisk społecznych i o różnym pochodzeniu rasowym w miejscu, które znane jest z konfliktów klasowych i napięć społecznych. Przykładowo, innowacyjne metody planowania miejskiego - mające na celu przeciwdziałanie dalszemu zanieczyszczaniu rzeki oraz wspierające powrót pstrąga stalowogłowego - wykształcono w wyniku współoddziaływania na środowisko miejskie dyskursów naukowych, ruchów społecznych i sił ekonomii politycznej. Stosowanie niektórych ze stworzonych przez hydrologów i ekologów praktyk planowania jest obecnie wymogiem; jednak wymogi te są często kwestionowane przez samorządy lokalne, które boją się ich wpływu na rozwój stanowiący cel deweloperów i firm budowlanych. Jakie dysputy naukowe doprowadziły do wypracowania takich rozwiązań oraz w jaki sposób czynniki polityczne i wysiłki aktywistów wpłynęły na standardy planowania przestrzennego, które obecnie obowiązują, regulując całkowity maksymalny dzienny poziom zanieczyszczeń wpuszczanych do rzeki oraz wód przybrzeżnych? W jaki sposób wizerunki zwierząt - zwłaszcza charyzmatycznych zwierząt wodnych [charismatic marine wildlife] - są wykorzystywane, aby promować odnowę środowiska rzeki i poprawę jakości wody w nadbrzeżnych obszarach oceanu w wyniku planowania miejskiego?

Wprowadzono kompleksowe plany zagospodarowania przestrzennego, które mają na celu odnowienie środowiska rzecznego przez budowę zbiorników retencyjnych, systemów nawodnienia, ścieżek rowerowych i szlaków dla pieszych, a także stworzenie zielonej wstęgi parków i otwartych przestrzeni. Wiele planów nie jest narzuconych przez władze stanowe, ale przygotowanych przez organizacje pozarządowe działające na poziomie krajowym i regionalnym, a także organizacje ochrony przyrody, które mają różne koncepcje i różne wizje dotyczące miejsca zwierząt w tkance miejskiej. Jak wyłania się struktura organizacji pozarządowych i działających na rzecz ochrony przyrody i jaka jest ich rola w zarządzaniu przestrzenią miejską? Czy stały się swoistym gabinetem 
cieni dla aparatu władzy, czy może trzecią władzą? W jaki sposób organizacje aktywistów i grupy lokalne są zaangażowane w próby stworzenia miejsc dla zwierząt wzdłuż rzeki?

Wraz z pozyskiwaniem funduszy na przedsięwzięcia związane z rzeką pojawiają się możliwości odnowy środowiska, a także ekonomicznej rewitalizacji biednych dzielnic w jej pobliżu oraz rekreacji dla spragnionych parków mieszkańców metropolii. Wykształciła się dynamicznie działająca sieć lokalnych organizacji, każda ze swoimi pomysłami na to, co zaplanować, i z inną polityką reprezentacji. Czy zbudowane zostaną boiska do piłki nożnej dla mieszkańców pochodzenia latynoskiego? Ścieżki dla anglosaskich mieszkańców, którzy lubią obserwować ptaki? Skatepark dla dzieci? Deptak dla umięśnionych macho, którzy mogliby się po nim przechadzać ze swoimi pitbullami? Kawiarnie dla singli? Parki dla psów? Jakiego rodzaju przyroda miejska i ekologia rzeki wyłonią się w końcu z takiej dynamiki ekologii politycznej?

Zwierzęta (nawet duże drapieżniki) na pewno pojawią się ponownie w ewoluującym zielonym korytarzu o tej skali i zaznaczą swoją sprawczość. Jakiego rodzaju miejsce zostanie dla nich stworzone? Wielu mieszkańców wspiera koegzystencję w teorii, a strumień ludzi (zwłaszcza dzieci), którzy już odwiedzają rzekę (z której nie usunięto jeszcze betonu), robi wrażenie. Jednak praktyka może okazać się odmienna. Czy ludzie będą w stanie - i czy będą chcieli - koegzystować ze zwierzętami związanymi z rzeką? Czy obawa przed przestępczością, żądania dostępu oraz pastoralne wyobrażenia krajobrazu doprowadzą do powstania rzeki jasnych świateł, dużego ruchu i uproszczonej wegetacji? Sprawiłoby to, że obszar byłby nie do zniesienia dla nieśmiałych, nocnych, lubiących samotność zwierząt lub takich, które potrzebują różnorodnej roślinności. Jeśli tak się stanie, kto przemówi w imieniu tych zwierząt? Czy może zwierzęta, które wrócą do rzeki, będą zmuszone wykształcić nowe podmiotowości, nowe sposoby interakcji z ludźmi i środowiskiem zbudowanym?

Związany z Los Angeles poeta Lewis MacAdams pojawił się na początku tego artykułu i wracam do jego postaci na koniec, aby przytoczyć przywołaną przez niego piękną opowieść o tym, jak Korpus Inżynieryjny Armii USA starał się przywrócić do stanu pierwotnego jeden z odcinków rzeki. Ponieważ zabezpieczenia przeciwpowodziowe są w dalszym ciągu wymagane, „odnowiony” odcinek rzeki nie zastąpił starego, uregulowanego kanału, ale został poprowadzony równolegle do niego - jest to więc, skrótowo rzecz ujmując, sztuczna natura, chwyt czysto estetyczny, a nie funkcjonalny element krajobrazu. Jednak wierzby i sitowie wróciły, tak samo jak ważki i przynajmniej niektóre ptaki. Czy ludziom będzie zależało na tym, żeby rzeka rzeczywiście była z powrotem „prawdziwa”? Czy wystarczy im, by obecność czworonożnych, skrzydlatych i beznożnych zwierząt - powrót anima urbis - była miarą re-animacji miasta?

Przełożyła Justyna Włodarczyk

\section{PRZYPISY}

1 Zob. J. Emel, J. Wolch, Witnessing the Animal Moment, w: też same, Animal Geographies: Place, Politics and Identity in the Nature-Culture Borderlands, London 1998, s. 1-26; M.J. Watts, Enclosure, w: Ch. Philo, Ch. Wilbert (red.), Animal Spaces, Beastly Places: New Geographies of Human-Animal Relations, London-New York 2000, s. 292-304.

2 Zob. D.R. Butler, Zoogeomorphology: Animals as Geomorphic Agents, Cambridge-New York 1995; B.A. Bryan, A Generic Method for Identifying Regional Koala Habitat Using GIS, "Australian Geographical Studies" 1997 nr 35, s. 125-139; L.D. Baer, D.R. Butler, Space-Time Modeling of Grizzly Bears, "The Geographical Review" 2000, nr 90, s. 206-221; T.W. Gillespie, Remote Sensing of Animals, „Progress in Physical Geography” 2001, nr 25 , s. 355-362.

3 Y.-F. Tuan, Dominance and Affection: The Making of Pets, New Haven, CT 1984.

4 "Environment and Planning D: Society and Space" 1995, nr 13: J. Wolch, J. Emel (red.), Bringing the Animals Back in, s. 631-760; też same, Animal Geographies..., dz. cyt.; Ch. Philo, J. Wolch, Through the Geographical Looking Glass: Space, Place, and Human-Animal Relations, "Society and Animals" 1998, nr 6, s. 103-118; Ch. Philo, Ch. Wilbert (red.), Animal Spaces, Beastly Places..., dz. cyt.

5 S. Baker, Picturing the Beast: Animals, Identity, and Representation, Manchester, NY 1993, s. 26.

6 M. Bekoff, J.A. Byers, Animal Play: Evolutionary, Comparative, and Ecological Perspectives, Cambridge-New York 1998; D. Fossey, Gorillas in the Mist, Boston 1983; B. Galdikas, Reflections of Eden: My Years with the Orangutans of Borneo, Boston 1995; D.R. Griffin, Animal Minds, Chicago 1992; J. Goodall, The Chimpanzees of Gombe: Patterns of Behavior, Cambridge, MA 1986; C. Moss, Elephant Memories, New York 1988; E. S. Morton, J. Page, Animal Talk, New York 1992; F. de Waal, Chimpanzee Politics, New York 1982. 
7 D. Haraway, Simians, Cyborgs and Women, New York 1991; J. Sheehan, M. Sosna (red.), The Boundaries of Humanity: Humans, Animals, Machines, Berkeley, CA 1991; P. Taylor, S. Halfon, P. Edwards (red.), Changing Life: Genomes, Ecologies, Bodies, Commodities, Minneapolis 1997.

8 D. Worster, Nature's Economy: A History of Ecological Ideas, wyd. 2, Cambridge-New York 1994.

9 W. Cronon, Changes in the Land: Indians, Colonists, and the Ecology of New England, New York 1983; tenże, Nature's Metropolis, Chicago 1991

10 D. Botkin, Discordant Harmonies: A New Ecology for the Twenty-first Century, New York 1990, s. 167

11 Wymienione przez Wolch tożsamości są oczywiście charakterystyczne dla kontekstu amerykańskiego z końca XX wieku. DINK to akronim od sformułowania Double Income, No Kids, które odnosi się do dobrze sytuowanych par bez dzieci, w których obydwoje partnerzy pracują zarobkowo. Wiejscy chłopcy to w ory ginale good ol' boys, termin, który można odnieść do amerykańskich entuzjastów polowań, zwykle słabo wykształconych mieszkańców zacofanych ekonomicznie rejonów USA [przyp. tłum.].

12 K. Anderson, A Walk on the Wild Side: A Critical Geography of Domestication, "Progress in Human Geography” 1997, nr 21, s. 463-485; tenże, The Beast Within': Race, Humanity, and Animality, Environment and Planning D: Society and Space" 2000, nr 18, s. 301-320; J.R. Ryan, 'Hunting with the Camera': Photography, Wildlife and Colonialism in Africa, w: Ch. Philo, Ch. Wilbert (red.), Animal Spaces, Beastly Places..., dz. cyt., s. 203-221; J. Emel, Are You Man Enough, Big and Bad Enough? Ecofeminism and Wolf Eradication in the USA "Environment and Planning D: Society and Space" 1995, nr 13, s. 707-734; C. Wilbert, Anti-This-Against-That: Resistances Along a Human-Non-Human Axis, w: J.P. Sharp i in. (red.), Entanglements of Power: Geographies of Domination/Resistance, London-New York 2000, s. 238-255; M. Woods, Fantastic Mr Fox? Representing Animals in the Hunting Debate, w: Ch. Philo, Ch. Wilbert (red.), Animal Spaces, Beastly Places..., dz. cyt., s. 182-202.

13 K. Anderson, Culture and Nature at the Adelaide Zoo: At the Frontiers of 'Human' Geography, "Transactions of the Institute of British Geographers" 1995, nr 20 NS, s. 275-294.

14 Ch. Philo, Animals, Geography and the City: Notes on Inclusions and Exclusions, "Environment and Planning D: Society and Space" 1995, nr 13, s. 655-681.

15 P. Howell, Flush and the Banditti: Dogstealing in Victorian London, w: Ch. Philo, Ch. Wilbert (red.), Animal Spaces, Beastly Places..., dz. cyt., s. 35-55.

16 B. Van Stipriaan, R.A. Kearns, Bitching about a Billboard: Advertising, Gender and Canine (Re)presentations, niepublikowany rękopis, Department of Geography, University of Auckland 2002

17 G. Elder, J. Wolch, J. Emel, La Practique Sauvage: Race, Place, and the Human-Animal Divide, w: J. Wolch, J. Emel (red.), Animal Geographies..., dz. cyt., s. 72-90.

18 M. Griffith, J. Wolch, U. Lassiter, Animal Practices and the Racialization of Filipinas in Los Angeles, "Society and Animals" 2002, nr 10, s. 221-248.

19 J. Wolch, A. Brownlow, U. Lassiter, Constructing the Animal Worlds of Inner-City Los Angeles, w: Ch. Philo, Ch. Wilbert (red.), Animal Spaces, Beastly Places..., dz. cyt., s. 71-97.

20 J. Wolch, U. Lassiter, From Barnyard to Backyard to Bed: Attitudes Toward Animals Among Latinas in Los Angeles, w: G. Hise, W. Deverell (red.), Land of Sunshine: An Environmental History of Metropolitan Los Angeles, Pittsburgh 2002

21 S. Whatmore, L. Thorne, Wild(er)ness: Reconfiguring the Geographies of Wildlife, "Transactions of the Institute of British Geographers" 1998, nr 23(4), s. 435-454.

22 T. Ingold, Culture and the Perception of the Environment, w: D. Parkin, E. Croll (red.), Bush Base, Forest Farm: Culture, Environment and Development, London 1992, s. 39-56. [Zob. też T. Ingold, Kultura i postrzeganie środowiska, przeł. G. Pożarlik, w: M. Kempny, E. Nowicka (red.), Badanie kultury. Elementy teorii antropologicznej, Warszawa 2003 - przyp. red. pol.].

23 Ch. Philo, Animals, Geography..., dz. cyt.

24 A. Gullo, U. Lassiter, J. Wolch, The Cougar's Tale, w: J. Wolch, J. Emel (red.), Animal Geographies... dz. cyt., s. 139-161.

25 S.H. Verhovek, An Expensive Fish, "New York Times", 16.03.1999, sekcja A, s. 14.

26 Zob. D. Cosgrove, S. Daniels (red.), The Iconography of Landscape, Cambridge 1988; P. Jackson, Maps of Meaning: An Introduction to Cultural Geography, London 1988; T.J. Barnes, J.S. Duncan, Introduction, w: ciż (red.), Writing Worlds: Discourse, Text and Metaphor in the Representation of Landscape, New York 1992 s. 1-17; M. Price, M. Lewis, The Reinvention of Cultural Geography, "Annals, Association of American Geographers" 1993, nr 83, s. 1-17.

27 Por. K. Anderson, The Racialization of Difference: Enlarging the Story Field, "The Professional Geographer" 2002, nr 54, s. 25-30; M. Davis, Ecology of Fear, New York 1998.

28 Zob. G. Gaard (red.), Ecofeminism: Women, Animals, Nature, Philadelphia, PA 1993.

29 D. Demeritt, The Nature of Metaphors in Cultural Geography: Geography and Environmental History " Progress in Human Geography" 1994, nr 12, s. 163-185.

30 F.M. Ufkes, Lean and Mean: US Meat-packing in an Era of Agro-Industrial Restructuring, „Environment and Planning D: Society and Space" 1995, nr 13, s. 683-706; R. Yarwood, N. Evans, New Places of 'Old Spots': The Changing Geographies of Domestic Livestock Animals, "Society and Animals" 1998, nr 6, s. 137-166; ciż, Taking 
Stock of Farm Animals and Rurality, w: Ch. Philo, Ch. Wilbert (red.), Animal Spaces, Beastly Places..., dz. cyt. s. 98-114; J. Proctor, The Spotted Owl and the Contested Moral Landscape of the Pacific Northwest, w: J. Wolch, J. Emel (red.), Animal Geographies..., dz. cyt., s. 191-217; D. Matless, Versions of Animal-Human: Broadland, c. 1945-1970, w: Ch. Philo, Ch. Wilbert (red.), Animal Spaces, Beastly Places..., dz. cyt., s. 115-140; A. Brownlow, A Wolf in the Garden: Ideology and Change in the Adirondack Landscape, w: Ch. Philo, Ch. Wilbert (red.), Animal Spaces, Beastly Places..., dz. cyt., s. 141-158.

31 Ch. Philo, Animals, Geography..., dz. cyt.

32 P. Howell, Flush and the Banditti..., dz. cyt.

33 A. Gaynor, Regulation, Resistance and the Residential Area: The Keeping of Productive Animals in Twentieth-Century Perth, Western Australia, "Urban Policy and Research" 1999, nr 17, s. 7-16.

34 H. Griffiths, I. Poulter, D. Sibley, Feral Cats in the City, w: Ch. Philo, Ch. Wilbert (red.), Animal Spaces, Beastly Places..., dz. cyt., s. 56-70.

35 J. Wolch, S. Rowe, Companions in the Park, "Landscape” 1992, nr 31, s. 16-33.

36 M. Davis, Ecology of Fear, dz. cyt., s. 204

37 Tamże, s. 208

38 T.D. Feldman, A.E.G. Jonas, Sage Scrub Revolution? Property Rights, Political Fragmentation, and Conservation Planning in Southern California Under the Federal Endangered Species Act, "Annals, Association of American Geographers" 2001, nr 90(2), s. 256-292.

39 Chodzi o Endangered Species Act z 1973 roku [przyp. red. pol.].

40 S. Pincetl, The Preservation of Nature at the Urban Fringe, w: J. Wolch, M. Pastor jr, P. Dreier (red.), Up Against the Sprawl? Public Policy and the Making of Southern California, Minneapolis 2002.

41 Ang. zguba, zmora [przyp. tłum.].

42 E.P. Evans, The Criminal Prosecution and Capital Punishment of Animals, London 1906

43 S. Berry, The Importance of Seeming Human, „Los Angeles Times Magazine”, 2.06.2002, s. 20, 21.

44 Ch. Stone, Should Trees Have Standing? Toward Legal Rights for Natural Objects, Los Altos, CA 1974 R. Nash, The Rights of Nature: A History of Environmental Ethics, Madison, WI 1989; J.B. Callicott, In Defense of the Land Ethic: Essays in Environmental Philosophy, Albany, NY 1989; B. Devall, G. Sessions, Deep Ecology: Living as if Nature Mattered, Layton, UT 1985; A. Salleh, Class, Race, and Gender Discourse in the Ecofeminist/ Deep Ecology Debate, „Environmental Ethics” 1993, nr 15, s. 225-244; P. Singer, Animal Liberation, New York 1975 [wyd. pol.: Wyzwolenie zwierzat, przeł. A. Alichniewicz, A. Szczęsna, Warszawa 2004]; T. Regan, The Case for Animal Rights, Berkeley, CA 1983;

45 Zob. V. Plumwood, Feminism and the Mastery of Nature, London 1993; M. Oelschlaeger, Postmodern Environmental Ethics, New York 1995.

46 J.L. Wescoat jr, The 'Right of Thirst' for Animals in Islamic Law: a Comparative Approach, „Environment and Planning D: Society and Space" 1995, nr 13, s. 637-654.

47 P. Robbins, Shrines and Butchers: Animals as Deities, Capital, and Meat in Contemporary North India, w: J. Wolch, J. Emel (red.), Animal Geographies..., dz. cyt., s. 218-240.

48 L. Thorne, Kangaroos: the Non-Issue, „Society and Animals" 1998, nr 6, s. 167-182.

49 J. Proctor, The Spotted Owl..., dz. cyt

50 M.J. Watts, Enclosure, dz. cyt

51 W.S. Lynn, Animals, Ethics and Geography, w: J. Wolch, J. Emel (red.), Animal Geographies..., dz. cyt., s. 280-2 97.

52 J. Wolch, M. Griffith, U. Lassiter, J. Zhang, Attitudes Toward Marine Wildlife Among Residents of Southern California's Urban Coastal Zone, Los Angeles, CA 2001.

53 Tego rodzaju konflikt miał miejsce w 2002 roku, kiedy przed mistrzostwami świata w piłce nożne w Seulu odbyły się międzynarodowe protesty przeciw jedzeniu psiego mięsa, co wywołało napięcia między działaczami na rzecz praw zwierzat a Amerykanami koreańskiego pochodzenia w USA. Zob. J. Feffer, The Politics of Eating Dog, "Toronto Star", 5.06.2002.

54 T. Nagel, Jak to jest być nietoperzem?, w: tegoż Pytania ostateczne, przeł. A. Romaniuk, Warszawa 1997

55 E.M. Thomas, The Hidden Life of Dogs, Boston 1993.

56 T. Vuorisalo, R. Lahtinen, H. Laaksonen, Urban Biodiversity in Local Newspapers: a Historical Perspective "Biodiversity and Conservation" 2002, nr 10, s. 1739-1756.

57 B.A. Bryant, A Generic Method for Identifying Regional Koala Habitat Using GIS, "Australian Geographica Studies" 1997, nr 35, s. 125-139.; T.W. Gillespie, Remote Sensing..., dz. cyt.; L.D. Baer, D.R. Butler, Space-Time Modeling..., dz. cyt.

58 Por. J. Wolch, Zoöpolis, „Capitalism Nature Socialism” 1996, nr 7, s. 21-48. 
59 M. Davis, Ecology of Fear, dz. cyt.

60 M. Dear (red.), From Chicago to LA, Thousand Oaks, CA 2002.

61 A.E.G. Jonas, D. Wilson (red.), The Urban Growth Machine: Critical Perspectives Two Decades Later, Albany, NY 1999.

62 S. Hanson, G. Pratt, Gender, Work, and Space, New York 1995; E. Wyly, D.J. Hammel, Capital's Metropolis: Chicago and the Transformation of American Housing Policy, "Geografiska Annaler, Series B, Human Geography" 2000, nr 82B(4), s. 181-206.

63 P. Joassart-Marcelli, J. Musso, J. Wolch, Federal Expenditures, Intrametropolitan Poverty and Fiscal Disparities in Southern California Cities, w: J. Wolch, M. Pastor jr, P. Dreier (red.), Up Against the Sprawl?..., dz. cyt.

64 L. Pulido, Rethinking Environmental Racism: White Privilege and Urban Development in Southern California, "Annals, Association of American Geographers" 2000, nr 90(1), s. 12-40.

65 J. Wolch, Zoöpolis, dz. cyt.; M. Davis, Ecology of Fear, dz. cyt.; A. Gullo, U. Lassiter, J. Wolch, The Cougar's Tale, dz. cyt.; A. Gaynor, Regulation, Resistance..., dz. cyt.

66 Por. Ch. Philo, Animals, Geography..., dz. cyt.; H. Griffiths, I. Poulter, D. Sibley, Feral Cats..., dz. cyt.; M. Griffith, J. Wolch, U. Lassiter, Animal Practices and the Racialization..., dz. cyt.; B. Van Stipriaan, R.A. Kearns, Bitching about a Billboard..., dz. cyt.

67 Por. P. Waley, What's a River Without Fish? Symbol, Space and Ecosystem in the Waterways of Japan w: Ch. Philo, Ch. Wilbert (red.), Animal Spaces, Beastly Places..., dz. cyt., s. 159-181; S. Michel, Golden Eagles and the Environmental Politics of Care, w: J. Wolch, J. Emel (red.), Animal Geographies..., dz. cyt., s. 162-190.

68 Por. T.D. Feldman, A.E.G. Jonas, Sage Scrub Revolution?..., dz. cyt.

69 L. Thorne, Kangaroos..., dz. cyt.

70 Kilka miast w USA zmieniło już swoje regulacje, usuwając terminy "właściciel zwierzęcia domowego" [pet owner] i "zwierzę domowe" [pet] i zastępując je określeniami „opiekun zwierzęcia” [animal guardian] oraz "zwierzę towarzyszące" [companion animal], aby zdestabilizować tradycję prawną traktowania zwierząt jako przedmiotów.

71 Wyjątkiem są badania Alana Becka: The Ecology of Stray Dogs: A Study of Free-Ranging Urban Animals, Baltimore, MD 1973; oraz Elizabeth M. Thomas, The Hidden Life..., dz. cyt.

72 B. Gumprecht, The Los Angeles River: Its Life, Death, and Possible Rebirth, Baltimore, MD 1999.

73 W.L. Graf, Damage Control: Restoring the Physical Integrity of America's Rivers, "Annals, Association of American Geographers" 2002, nr 91, s. 1-27.

74 J.McPhee, The Control of Nature, New York 1989.

75 D.R. Browne, R. Keil, Planning Ecology: the Discourse of Environmental Policy Making in Los Angeles, "Organization and Environment" 2000, nr 13, s. 158-205. 


\section{Peter Atkins}

\section{Zwierzęce nieczystości i utrapienia w dziewiętnastowiecznym Londynie}

\section{Brud, nieczystości i natura}

Mary Douglas w znany już powszechnie sposób określiła brud jako „coś nie na swoim miejscu” lub, ściślej, jako coś „obrzydliwie lub niedopuszczalnie nie na swoim miejscu”. Bardziej jednak niż chorobotwórczym potencjałem żyjących w brudzie mikroorganizmów zainteresowana była skutkami nieczystości społecznej, ponieważ „osoba nieczysta zawsze jest po złej stronie” ${ }^{\text {. }}$ Według niej więc brud uwidaczniał marginesy tego, co społecznie akceptowalne ${ }^{3}$. Domyślna jest tu ontologia relacyjna, zmieniająca się w zależności od czasu i przestrzeni - twój brud może być dla mnie niewidoczny - dlatego więc w większości literatury nawiązującej do koncepcji Douglas zakłada się milcząco, że poglądy na temat brudu lub nieczystości oraz decyzje dotyczące tego, jak sobie z nimi radzić, są najwyżej tymczasowymi stabilizacjami politycznymi, nieuchronnie uwikłanymi w sieci zależności ${ }^{4}$ Będę argumentował, że jedna z takich stabilizacji - entuzjazm dla kanalizacji z połowy XIX wieku - stanowiła przełom w sposobach pojmowania brudu i nieczystości, który wpłynął na to, do jakiego stopnia zwierzęta były włączone w główny projekt nowoczesnego urbanizmu.

$[\ldots]$

\section{Wstrętny brud i smród}

Począwszy od XVIII wieku, nowoczesne społeczeństwa miejskie ${ }^{5}$ doświadczyły kilku zmian ontologicznych, jeśli chodzi o stosunek do brudu. Na samym początku był on akceptowany jako przedłużenie trybu życia właściwego wsi, skąd wywodziła się większość przyjezdnych. Później budził lęk i był eliminowany z zapałem powodowanym względami sanitarnymi, choć ostatecznie gorliwość ta osłabła, do tego nawet stopnia, że-jak można dowodzić w pierwszej połowie XX wieku w odniesieniu do pożywienia brud nie był już tak ważną kwestią i przestał być postrzegany jako zagrożenie w taki sam sposób jak wcześniej ${ }^{6}$. Dzisiaj nasze poglądy znów się zmieniły, tak dalece, że posługujemy się kategorią „dobrego brudu”, istotnego dla 
rozwoju naszego układu odpornościowego. Zbiorowa percepcja ulegała więc wraz z upływem czasu wielu zmianom. [...] Poglądy dotyczące miejskich „zapachobrazów” [smellscapes] także ewoluowały. Późnoosiemnastowieczne i wczesnodziewiętnastowieczne miasta były wówczas odbierane jako notorycznie brudne i śmierdzące ${ }^{7}$. Częściowo wynikało to z rozwoju romantycznych wizji wiejskich krajobrazów, które - przez porównanie - sprawiały, że brud i nieporządek przestrzeni miejskich wydawał się bardziej widoczny i naganny ${ }^{8}$.

Ówczesne relacje pełne są opisów brudnych ulic, zagraconych domostw i skażonych rzek, a jakość powietrza była zła z powodu opalanych węglem domowych palenisk oraz emisji zanieczyszczeń przemysłowych. Alain Corbin pokazuje, że koncepcja niebezpiecznych odorów nie była niczym nowym, jednak we wczesnej fazie urbanizacji miazmatyczna teoria chorób zyskiwała na popularności jako „zdroworozsądkowe" wytłumaczenie współzależności pomiędzy występowaniem chorób a coraz bardziej brudnym i nieuporządkowanym środowiskiem ${ }^{9}$. Pod koniec XVIII wieku pytania dotyczące epidemii doprowadziły do rozważań na temat istoty zarażeń; początkowo w związku z klimatem, później jednak coraz częściej w odniesieniu do odorów i roznoszących zarazki gazów wydostających się z odpływów, cmentarzy, rzeźni oraz miejskich ulic pokrytych końskimi odchodami. $\mathrm{Na}$

Obecność zwierzq̨t nie wynikała więc z przypadkowego niedopatrzenia obywateli, którzy w pewnym momencie mieliby wreszcie się opamiętać i odkryć prawdziwą istotę urbanizmu. Można raczej dowodzić konstytutywnej roli zwierząt dla określonego etapu rozwoju miasta. przełomie XVIII i XIX wieku zagadnienie zdrowia publicznego było dyskutowane przy wykorzystaniu analiz geografii brudu, pojawiły się też wtedy pierwsze oznaki mentalności interwencyjnej.

Według Petera Stallybrassa i Allona White’a to przede wszystkim zmysł węchu zaangażował przyszłych reformatorów społecznych; obawiano się bowiem wszechogarniającej i niewidocznej obecności zapachu, którą trudno było nadzorować ${ }^{10}$. W związku z tym do lat 30. XIX wieku zwierzęce i ludzkie nieczystości stały się kwestią skupiającą coraz więcej uwagi.

Nagromadzone nieczystości, które wcześniej były postrzegane jako nieprzyjemny, ale nieunikniony element życia w mieście, teraz zdawały się świadczyć o występnym, a nawet morderczym lekceważeniu życia. W ekskrementach nie widziano już po prostu produktów ubocznych procesów życiowych, ale ożywiony i wrogi brud, który - gdyby tylko dać mu szansę - zaatakowałby samo ciało ${ }^{11}$.

Nadzór sanitarny w pewnym sensie odpowiadał na egzystencjalny miejski lęk rozpoznany na początku XIX stulecia, który narodził się wraz ze zrozumieniem, że miasta są jednocześnie twórcze i przerażająco destruktywne ${ }^{12}$. Tymczasem rosnąca odraza do zwierzęcych odchodów i wydzielin nie wynikała raczej z obawy przed tym, co niezwykłe lub nieznane. Dwa miliony londyńskich nosów były przyzwyczajone do ich wszechobecności, a strach przed nimi stawał się kształtującym tożsamość dążeniem rozwijającej się klasy średniej. Niebezpieczny miazmat lub wyimaginowana brudna i roznosząca zarazki chmura gazu, która jakoby wydobywała się z zanieczyszczonej ziemi, były w tyleż niepokojący, co satysfakcjonujący sposób niematerialne. Wszyscy wiedzieli, że gdzieś się znajdują, unoszą się nad najbrudniejszymi częściami miasta, ale nikt nigdy ich nie widział ani nie zmierzył ${ }^{13}$. Były niewidzialne, nieuchwytne, a jednak zabójcze ${ }^{14}$.

Miazmatyczna teoria chorób dostarczała wiarygodnej ramy wyjaśniania, pozwalającej na powiązanie choroby zarówno z ludzkimi, jak i zwierzęcymi nieczystościami, a to w umysłach wielu ludzi wywołało „kryzys fekalny”15. Możemy uchwycić sens tego zjawiska, przytaczając 
kilka cytatów z najważniejszego wówczas podręcznika do medycyny, czyli Dictionary of Practical Medicine Jamesa Coplanda. Autor kładł nacisk na „zwierzęce wyziewy”, przez które rozumiał wszystkie wonie związane ze zwierzętami oraz odpadkami zwierzęcego pochodzenia:

Niektóre [...] przyczyny choroby, nie mniej istotne, a przede wszystkim miazmaty bagienne oraz szkodliwe zwierzęce wyziewy, działają bezpośrednio na organiczne nerwy płuc i na samą krew poprzez metodę absorpcji16.

W latach 40. XIX wieku świadomość społeczna została podniesiona dzięki fali oficjalnych raportów, takich jak Report on the Sanitary Condition of the Labouring Population of Great Britain z 1842 roku [Raport o stanie zdrowia pracującej ludności Wielkiej Brytanii] autorstwa Edwina Chadwicka ${ }^{17}$. To właśnie w takich rządowych sprawozdaniach możemy przeczytać bardzo szczegółowe opisy ekskrementów i innych zwierzęcych pozostałości, włączając w to gnijące zwłoki, części ciała i krew, które uważane były za jedne z najbardziej odrażających elementów ulicznych śmieci. [...] Podtrzymywanie stanu zszokowania było z pewnością kluczowe dla wypracowania politycznego konsensusu umożliwiającego interwencję oraz ugruntowania pewności, by wypróbowywać rozwiązania kosztowne i dotąd nietestowane na dużą skalę. [...]

W swoich opisach zwierzęcych odchodów Chadwick i inni miazmatycy zdają się nieomal rywalizować ze sobą o wywołanie jak największego obrzydzenia u czytelnika - to oni ożywili debatę publiczną, która skupiła dość energii, by przetrwać stulecie. Niezależnie od prawdziwych przyczyn - a uwagę, oczywiście, przekierowano ostatecznie na teorię zarazków i takich nosicieli czynników chorobotwórczych jak muchy - zwierzęce brud i zapachy nigdy potem nie były już akceptowane w mieście. Nawet pozornie niezbędny koń pod koniec XIX wieku został poddany rygorystycznej kontroli ze względu na odchody, jakie pozostawiał na ulicy. [...]

Od tego momentu zwierzęta coraz rzadziej uznawane były za prawowitych mieszkańców miasta, a usuwanie ich i związanych z nimi uciążliwości z przestrzeni miejskiej wykorzystywano jednocześnie jako sposób na nadzorowanie i dyscyplinowanie ich właścicieli oraz na kontrolowanie środowiska stwarzającego zagrożenie. Ponieważ nieczystości w drugiej połowie XIX wieku coraz częściej należały do sfery liminalnej - brudnej, odrażającej i odległej-stawiano patrole na granicach tych społecznie konstruowanych wyobrażeń o tym, co jest akceptowalne ${ }^{18}$. To, co mogło być dozwolone w mieście, łączyło się z kwestią czystości cielesnej, a zwierzęta coraz bardziej utożsamiane były z dwoma podstawowymi wyczuwalnymi wykroczeniami: smrodem i widocznym brudem, takim jak odchody. [...]

\section{Nie na miejscu czy konstytutywne dla „urb-an-imalizmu"?}

Jak zauważył kiedyś Fernand Braudel, „wszystkie wielkie okresy wzrostu znajdują wyraz w eksplozji miast"19. Tak było też pod koniec XVIII i na początku XIX wieku, kiedy brytyjska rewolucja przemysłowa i ekspansja handlowa wywołały niespotykanie szybką i pod wieloma względami chaotyczną urbanizację. Istniejące instytucje władz lokalnych nie potrafiły sobie poradzić ze zorientowanym na zysk barbarzyństwem kapitalizmu przemysłowego ani ze spekulacyjną anarchią towarzyszącą mieszkalnemu i komercyjnemu zagospodarowywaniu terenów. W tym czasie „miasta szoku” [shock cities] nie były traktowane przychylnie; w powszechnym odbiorze kojarzyły się z pejzażem skąpanym w światłocieniu, w którym wszelki kolor przykryty był mgłą lub spływał do ścieków wraz z tak licznymi zanieczyszczeniami.

Brud, odpadki i im podobne miały swoje miejsce w XVIII i na początku XIX wieku. Nie były mile widziane, niemniej akceptowano je, a nawet ceniono w wąskim rozumieniu tego słowa. W mieście niemal wszystko posiadało wartość użytkową oraz wartość wynikającą z możliwości ponownego użycia. Dobrobyt i praca były przynajmniej częściowo związane z jak najpełniejszym wykorzystaniem odpadków ${ }^{20}$, i nawet gnijące zwłoki dryfujące Tamizą okazały się wartościowe w oczach przewoźnika z powieści Nasz wspólny przyjaciel ${ }^{21}$. Gaffer Hexam utrzymywał się z odzyskiwania i sprzedawania dryfujących śmieci, był jednak wyłącznie małym trybikiem w machinie recyklingu, która wyciskała ostatnią kroplę wartości z tego, co uznano za zbędne. Najbardziej zajmujących opisów tego świata dostarczają szczegółowe reportaże 
Henry'ego Mayhew o osobach tworzących w 1851 roku armię kanalarzy, nocnych robotników wywożących nieczystości i śmieciarzy przeczesujących kanały oraz rzeczny muł². Mayhew sprawił, że stali się oni znaną społecznością w rozumieniu Raymonda Williamsa - z samych obrzeży społeczeństwa zostali przez literaturę powołani do życia²3.

Przedmiotom bezpowrotnie zepsutym pozwalano ostatecznie wypaść z miejskiego cyklu powtórnego użycia, ale odpadki organiczne, pod postacią substancji odżywczych, mogły w nim krążyć w nieskończoność. [...]

Zwierzęcy mieszkańcy nowych i gwałtownie zmieniających się miejskich światów z XVIII i XIX wieku wiedli mglistą, liminalną egzystencję. Miasta te, niczym mityczne ogry, żywiły się potem mięsem swych koni oraz mięsem i krwią innych zwierząt gospodarskich. Było zupełnie tak, jakby odchody tych stworzeń wsiąkały w ulice i użyźniały rozwój miast, a ich ból był częścią energii układu nerwowego miejskiego życia. Jednym z paradoksalnych skutków fundamentalnego znaczenia zwierząt było to, że „wieś” nadal trwała w „mieście” i dopiero regulacyjne narzucenie koncepcji, co składa się na „dobre miasto”, sprawiło, że „wielkie oddzielenie” [great separation] miasta i wsi mogło najpierw pojawić się jako myśl, a potem zostać wdrożone:

Choć wiktorianie często lamentowali nad utratą wiejskości, nam miasto wiktoriańskie wydałoby się dziwaczną mieszanką miejskości i scenerii zagrody, z miejskimi domami przeplatanymi stajniami, chlewami i jatkami, gdzie owce i krowy walczyły o miejsce z ruchem konnym, a świnie i kurczaki mieszkały tuż obok ludzkich domostw. Tak więc miasto rozumiane jako artefakt symbolizowało społeczność wiejską przechodzącą gwałtowne i niekontrolowane przemiany ${ }^{24}$

Parafrazując cytowaną często uwagę Davida Harveya, można powiedzieć nie tylko to, że w Londynie w roku 1840 nie było nic nienaturalnego, lecz także nawet to, że stanowił on apogeum możliwości działającego i produkującego pożywienie „urb-an-imalizmu” [urb-an-imal], a więc określonego typu zurbanizowanej natury ${ }^{25}$.

Obecność zwierząt nie wynikała więc z przypadkowego niedopatrzenia obywateli, którzy w pewnym momencie mieliby wreszcie się opamiętać i odkryć prawdziwą istotę urbanizmu. Można raczej dowodzić konstytutywnej roli zwierząt dla określonego etapu rozwoju miasta. Ułatwiały one ten rozwój, napędzały go, zapewniały też kluczową, stałą łączność z równolegle funkcjonującą ekonomią wiejską. Ogromny rozwój miast w wieku XIX oraz proces ich ewolucji od tych, w których poruszano się pieszo, opierał się bowiem na transporcie konnym: omnibusach i tramwajach, dorożkach i prywatnych wierzchowcach. Tramwaje elektryczne z lat 90. XIX wieku oraz pojazdy mechaniczne z połowy kolejnej dekady wspólnie utorowały drogę do nowego typu miasta, pozbawionego już zwierzęcego potu i zapachów, które dotychczas - co traktowano jako oczywistość - pełniły funkcję smaru oliwiącego tryby życia codziennego. Zmiana ta jednak następowała stopniowo i zajęła kilka dekad.

W 1840 roku dla wszystkich zainteresowanych było jasne, że ogromne ilości zwierzęcego łajna i ludzkich ścieków, wytwarzane przez szybko rozwijające się miasta, albo trzeba było wykorzystać, albo należało się ich pozbyć. Dopuszczanie do gromadzenia nieczystości w dzielnicach mieszkalnych było już nie do zaakceptowania. To właśnie w tym roku Justus von Liebig przedstawił teorię mineralną odżywiania się roślin, która głosiła, że żyzność gleby w krajach Europy Zachodniej powoli spada wskutek pozyskiwania z niej środków odżywczych bez jednoczesnego ich uzupełniania w systemach intensywnej uprawy roli ${ }^{26}$. Marks określił ten proces mianem „pęknięcia metabolicznego” w relacjach pomiędzy ludźmi i ich środowiskiem ${ }^{27}$. Liebig sugerował, że zarówno odchody zwierzęce, jak i ludzkie ścieki powinny zostać wykorzystane do przywracania równowagi w składzie chemicznym gleby tam, gdzie zachodziłaby taka konieczność ${ }^{28}$. W ślad za jego publikacją w Wielkiej Brytanii, Ameryce, Szwecji, Francji i Niemczech w ciągu kilku lat zaczęły pojawiać się książki traktujące o „oborniku”, popularyzujące twierdzenie Liebiga o znaczeniu gnoju dla przyszłej żyzności ziemi i produktywności rolnictwa ${ }^{29}$.

[...]

Aż do lat 60. XIX wieku i później istniała więc koncepcja życia użyźnionego, ponownie ożywionego, odrodzonego z odpadków ${ }^{30}$. Jak pisał Graeme Davison, stała się ona organiczną 
metaforą dla życia jako takiego, a dyskurs recyklingu utrzymany w tym tonie jest oczywiście dobrze znany i nam na początku XXI wieku¹3. Odrzuca on negatywne skojarzenia z nieczystościami i wychwala możliwość stworzenia obiegu odnawialnych zasobów. W odniesieniu do zaopatrzenia w żywność łatwo było zrozumieć, jakie możliwości dawało ponowne wykorzystanie odpadków, takich jak odchody zwierząt oraz części ich ciał, ponieważ nie ulegało wątpliwości, że ich energia i siła musiały w jakimś stopniu przekładać się na żyzność gleby. To właśnie stało się kluczowym ogniwem łączącym miasto ze wsią: recyklingowanie odpadków pochodzących z takich miast jak Londyn i Paryż w ogrodach oraz gospodarstwach produkujących na ich potrzeby, znajdujących się w zasięgu transportu konnego.

Ostatecznie tej fazie urbanizmu opartego na zwierzętach, trwającej mniej więcej od połowy XVIII do końca XIX wieku, cios zadały brud i odór. Nieuchronnie kojarzono je z żyjącymi w miastach zwierzętami: zarówno końmi zaprzęgowymi, jak i producentami żywności, takimi jak krowy mleczne oraz świnie. Były również efektem lokalizowania w miastach wielu cuchnących fabryk przetwarzających produkty uboczne pochodzenia zwierzęcego: krew, tłuszcz, kości. Wszystko to stanowiło wyzwanie dla ruchu higienicznego, zwłaszcza od lat 40. XIX wieku i później. Jak zauważyła Michelle Allen, to właśnie szczegółowa i zarazem szeroka definicja brudu w tym okresie dała początek równie szczegółowej oraz pojemnej definicji czystości. Brud wiktoriański stworzył, można by rzec, reformę sanitarną; to znaczy ten konkretny sposób, w jaki wiktorianie wyobrażali sobie brud, przyczynił się do powstania wyobrażenia czystości, które wykrystalizowało się wraz z reformą sanitarną [...]. Reforma sanitarna była więc w niepowtarzalny sposób dostosowana zarówno do rzeczywistych warunków, jak i do metaforycznych znaczeń narosłych wokół brudu w XIX wieku².

\section{Rolnictwo miejskie}

Kiedy w 1987 roku po raz pierwszy odwiedziłem Indie, ze zdziwieniem odnotowałem skupiska mlecznych bawołów blisko centrum Madrasu (obecnie Ćennaj), utrzymywanych w warunkach przypominających te, które panują w osadach na najodleglejszej wsi. Od tego czasu w Indiach rozwinęły się planowanie urbanistyczne i regulacje dotyczące żywności, ale istnieją inne kraje w Afryce i Azji, gdzie produkcja świeżej żywności pochodzenia zwierzęcego jest w mieście nie tylko tolerowana, lecz także aktywnie wspierana. Ruch na rzecz rolnictwa miejskiego wpisuje się w taki sposób myślenia o rozwoju, który opowiada się za większą samowystarczalnością żywieniową mieszkańców miast; dostępne są liczne badania sugerujące, że uprawa na poboczach dróg oraz trzymanie bydła na niezajmowanych działkach może w dużym stopniu przyczynić się do rozwiązania problemu ubóstwa oraz dodatkowo znieść koszty transportu pożywienia, które trzeba sprowadzać z daleka. Obecnie około 800 mln ludzi na świecie zaangażowanych jest w miejską i podmiejską produkcję żywności, z czego 200 mln wytwarza ją na potrzeby rynku³3. Na Kubie 80 procent produkcji ogrodniczej pochodzi z miejskich upraw.

Nie próbuję tu wykazywać, że zachodzą istotne podobieństwa między miastami wiktoriańskimi a miastami współczesnego Trzeciego Świata. Jednak niezgodność między „miejskim” a „rolniczym” w epoce nowoczesnej zaczęła wydawać się tak fundamentalna, że należałoby przypomnieć sobie, iż są możliwe inne modele urbanizacji, w ramach których trzymanie zwierząt nie jest zakazane. W szczególności istnieje wiele hybrydycznych form natury i społeczeństwa wartych głębszego zbadania, na co w tym rozdziale brakuje miejsca ${ }^{34}$.

W szczytowym okresie produkcji żywności pochodzenia zwierzęcego w miastach Wielkiej Brytanii, czyli w połowie XIX wieku, ówcześni komentatorzy wyrażali się o tym fenomenie z mieszaniną oburzenia i rozbawienia. Gniew odnajdziemy w opisie obór w Whitechapel, w środku londyńskiego East Endu, autorstwa Thomasa Beamesa. Sugerował on, że „mało co jest od nich większą zmorą" oraz że

zwierzęta karmione niewłaściwym pożywieniem dają mleko ledwie nadające się do wykorzystania, a ich szopy potwornie cuchną; nie minęło dużo czasu, od kiedy obrzydzenie opinii publicznej wzbudziło doniesienie o krowach 
trzymanych [...] w Whitechapel w podziemnych szopach, gdzie od dawna nie widziały światła dziennego. Było to prawie tak okropne jak utrapienie z [...] dzielnicy Berwick Street, gdzie w oborze otoczonej ze wszystkich stron budynkami, i to nie tylko na parterze, ale nawet na pierwszym piętrze, żyje dużo krów i świń. Podobne mleczarnie usytuowane w zamkniętych budynkach z całą pewnością powinny zostać usunięte ${ }^{35}$.

George Sims w bardziej satyrycznym tonie przywoływał sprawę sądową z Londynu, gdzie

jakiś czas temu pewnemu mężczyźnie postawiono zarzut znieważenia żony i podczas przesłuchania sądowego ustalono, że małżeńska kłótnia dotyczyła osła, który spał pod łóżkiem. Sędzia był, rzecz jasna, zaskoczony. Nie chciał uwierzyć, że coś takiego mogło się zdarzyć. Jego zdumienie podzielała niewątpliwie publiczność. Obecność osła w mieszkaniu straganiarza i jego rodziny nie jest jednak w żadnym razie czymś rzadkim i całkiem niedawno pewien gorliwy inspektor sanitarny odkrył piwnicę zamieszkaną przez mężczyznę, jego żonę, trójkę dzieci i cztery świnie ${ }^{36}$.

W pewnym sensie to, czy podobne historie były prawdziwe czy zmyślone, nie miało żadnego znaczenia. W czasie gdy Sims spisywał swoje relacje, opinia publiczna dawno już doszła do wniosku, że żywe zwierzęta hodowlane i miasta nie tworzą zgranego duetu. Historycy ekonomii wskazują jednak, że skala tego typu produkcji miejskiej nadal była całkiem duża. [...]

Ekonomiczne uzasadnienie tej miejskiej działalności wynikało: po pierwsze, z wyjątkowej podatności mleka na zepsucie, co powodowało, że często docierało ono do miasta niezdatne do spożycia po transporcie koleją z odległych gospodarstw; po drugie, z procederu fałszowania go poprzez rozrzedzanie wodą, który był tak rozpowszechniony, że konsumenci darzyli dostawców z sąsiedztwa większym zaufaniem niż anonimowych wiejskich producentów; po trzecie, wielu miejskich hodowców krów przybyło ze wsi, więc handel mlekiem stanowił dla nich zarówno możliwość podtrzymywania umiejętności nabytych na wsi, jak i sposób na wejście w obcy pod innymi względami system ekonomiczny metropolii. W przypadku Londynu byli to głównie Walijczycy, pochodzący przede wszystkim z takich hrabstw jak Cardiganshire ${ }^{37}$. Wydaje się, że trzymanie zwierząt w mieście było dla nich po prostu jednym z aspektów miejskiego stylu życia i wpisywało się w kontekst kulturowy, na który składały się także: wzajemne wsparcie, niedzielne nabożeństwa i w wielu przypadkach język walijski ${ }^{38}$.

Żyjące w Londynie krowy dające mleko były zwierzętami bardzo wartościowymi, o wysokiej wydajności mlecznej, przynoszącymi wystarczający zysk, by uzasadnić wydatki na paszę i ogólne koszty utrzymania w mieście. Na ogół nie hodowano ich długo i gdy tylko zaczynało brakować im mleka, były tuczone i sprzedawane rzeźnikowi. Aby obniżyć koszty hodowli, niektórzy ich właściciele kupowali zużyte ziarno z browarów i gorzelni ${ }^{39}$. Te „wywarowe” lub „zlewkowe mleczarnie” były popularne także w Ameryce, jednak spotykały się tam z o wiele większą krytyką niż w Wielkiej Brytanii. John Mullaly opisał jedną z nich z Sixteenth Street w Nowym Jorku - mieszczącą się pomiędzy Tenth Avenue a południowym odcinkiem rzeki Hudson - która wzbudziła obrzydzenie u większości jego czytelników. Rozgłos, jaki nadał sprawie, doprowadził do zakazania „zlewkowych mleczarni” w Nowym Jorku w 1873 roku:

Budynki i teren są własnością pana Johnsona, właściciela sąsiedniej gorzelni, z której dostarcza bydłu wywar gorzelniany lub zlewki. Znajdują się tam, ściśle mówiąc, trzy obory umieszczone równolegle względem siebie od drogi do rzeki. [...] Budynki są długie na sto pięćdziesiąt do dwustu metrów, a każdy pomieści od sześciuset do siedmiuset krów. Ich wygląd zewnętrzny zniechęca, a fetor daje się niekiedy wyczuć z odległości półtora kilometra; ale widok zewnętrzny, choć odrażający, nie może dać pojęcia o tym, jak wygląda wnętrze. Krowy ustawione są w kolejnych rzędach, po czternaście, piętnaście w rzędzie, i są oddzielone od siebie drewnianymi przegrodami sięgającymi najwyżej ich łopatek. Przed każdym rzędem stoi koryto ze zlewkami, 
a do jednej z belek, które tuż nad nim tworzą obramowanie, krowy przytroczone są za pomocą sznura zawiązanego wokół ich karków. Nieszczęsne zwierzęta tak są ustawione, by niemal nieustannie znajdować się przed korytem, z wyjątkiem chwil, gdy się położą; a nawet ta pozycja, zamiast umożliwić odpoczynek, przynosi im tylko nową torturę, ponieważ parter tych obór zazwyczaj przesączony jest zwierzęcymi odchodami. Nie trzeba chyba dodawać, że obory utrzymywane w takim stanie nie mogą być dobre dla zdrowia, a atmosfera, która je przenika, sama w sobie wystarczyłaby, by skazić mleko i uczynić je niezdatnym do użytku [...]. Zlewki są silną używką, więc ich wpływ na organizm i zdrowie zwierząt jest bardzo podobny do wpływu napojów alkoholowych na organizm ludzki. W ciągu dnia każda krowa wypija około stu litrów młóta, zatem całkowite jego spożycie w oborach wynosi około dwustu tysięcy litrów. Ilość mleka uzyskiwanego na tej paszy waha się od sześciu do 30 litrów dziennie, to jest co dwadzieścia cztery godziny. Krowy dojone są dwa razy dziennie, raz o trzeciej nad ranem, drugi raz o drugiej lub trzeciej po południu ${ }^{40}$.

$[\ldots]$

Istotne są tu dwa przykłady kształtowania się wiedzy. Po pierwsze, w połowie XIX wieku producenci mleka wierzyli, że ciepłe obory pozwalają na zmaksymalizowanie udoju. W konsekwencji budynki te często były kiepsko wentylowane. Zwykle łączyły się z tym: słabe oświetlenie, źle funkcjonujące oczyszczanie i odpływ ścieków oraz brak dostępu do czystej wody. Niszczejące obory, na które w 1850 roku wszędzie można było się natknąć, stanowiły doskonałe środowisko dla przenoszonych drogą kropelkową chorób bydła, a nagromadzone odchody zwierzęce stały się pierwszorzędnym celem dla higienicznej mentalności. [...].

Drugi kierunek rozwoju wiedzy miał charakter entomologiczny. Opierał się na lepszym zrozumieniu ekologii muchy domowej oraz - przede wszystkim - jej związków z końskimi odchodami. Prace Dawn Day Biehler dotyczące miast amerykańskich wskazują, że tam entomologia zaczęła wywierać wpływ na sanitarne imaginarium w ostatnim roku czy dwóch ostatnich latach XIX wieku ${ }^{41}$. Nastąpiło to po wybuchu epidemii tyfusu w 1895 roku w Waszyngtonie, kiedy chorobę powiązano ze stojącymi na zewnątrz domostw szaletami, w których mnożyły się muchy. Pierwsza dekada nowego stulecia była okresem kształtującego się przekonania o zagrożeniu muchami, opartego przede wszystkim na dostrzeżonym związku pomiędzy tymi owadami potraktowanymi jako nosiciele czynników chorobotwórczych a biegunką niemowlęcą, którą, jak sądzono, wywoływało spożywanie przez dzieci zakażonego mleka. Ten budzący wiele emocji związek spowodował w Wielkiej Brytanii rozpoczęcie badań, a w efekcie w wielu oficjalnych i akademickich publikacjach zidentyfikowano muchy jako zagrożenie ${ }^{42}$.

Kiedy weźmiemy pod uwagę wzrost populacji koni miejskich po obu stronach Atlantyku w drugiej połowie XIX wieku, wyda się prawdopodobne, że ich odchody rzeczywiście przyczyniły się do rozmnożenia się muchy domowej i do zwiększenia przepływów bakteriologicznych ${ }^{43}$. Z innych prac wiemy z kolei, że w tamtym okresie wiele kobiet z klasy średniej rezygnowało z karmienia piersią i podawało niemowlętom mleko krowie z butelki. Te specjalne pojemniki, często wyposażone w długą, gumową rurkę, która łatwo mogła zostać zanieczyszczona przez muchy lub brud, były trudne do sterylizacji. Muchy stanowiły więc tylko jeden z wielu czynników, jakie zagrażały wówczas dzieciom ${ }^{44}$.

Rozwój tych dwóch koncepcji w kontekście popularnych poglądów na temat miejskiego rolnictwa stanowi przykład, jak duże znaczenie miały ustalone systemy przekonań oraz ich kolizja z nowymi dziedzinami nauki, które w tym czasie powstawały. W latach 80. i 90. XIX wieku teoria zarazkowa chorób oraz bakteriologiczne prace Roberta Kocha, Louisa Pasteura i innych wprowadzały zupełnie nowe sposoby rozumienia zarówno zagrożeń, jakie niósł ze sobą brud, jak i natury czynników chorobotwórczych. Na początku były to jednak koncepcje często wyśmiewane lub ignorowane. W przypadku obór najważniejsze było zdanie lokalnych służb sanitarnych dotyczące bakterii w mleku, a także ich gotowość, by domagać się odpowiednich działań od miejscowych władz. Niewątpliwie ważny był nacisk wywierany przez lokalnych aktorów, choć mało mamy świadectw na ten temat. The Metropolis Management Amendment Act [Ustawa 
o naprawie zarządzania metropolią, 1862] dostarczył władzom sanitarnym w Londynie podstaw do uruchomienia systemu wydawania licencji, który pozwalał na zamykanie poszczególnych placówek lub na narzucanie rygorystycznych warunków odnowienia licencji podczas corocznych drobiazgowych posiedzeń ${ }^{45}$. W rzeczywistości jednak tylko w zamożnych dzielnicach na West Endzie było dość woli politycznej, by urzeczywistniać ducha tych postanowień, natomiast w innych częściach Londynu nieprzyjemne zapachy i inne związane z nimi uciążliwości uprzykrzały życie jeszcze przez dekady. Reszta kraju musiała czekać aż do wprowadzenia w 1878 roku Contagious Diseases (Animals) Act - ustawy o zakaźnych chorobach (odzwierzęcych), która legła u podstaw regulacji ogólnopaństwowych. Znalazła ona rozwinięcie w serii rozporządzeń dotyczących mleczarni, obór i sklepów sprzedających mleko (1879, 1885, 1886, 1899), stopniowo zaciskających pętlę wokół miejskiego przemysłu mleczarskiego. Wzrosła liczba inspekcji, zgłaszano też więcej zastrzeżeń w trakcie sesji, gdy przydzielano licencje. Wszystko to zmusiło hodowców krów do wprowadzania kosztownych zmian i w swoich budynkach gospodarczych, i w metodach chowu. Ponieważ marże w handlu mlekiem były już i tak niskie, wielu producentów zostało ostatecznie wypchniętych z miasta lub nawet z rynku.

$[\ldots]$

$\longrightarrow$ "Wielkie oddzielenie"

Mrok niezrozumienia i niechęci otaczający „miasto bakteriologiczne” z połowy XIX wieku częściowo brał się z tego, iż nikt nie sądził, że dostępne są jakiekolwiek proste rozwiązania ${ }^{46}$. Edwin Chadwick, pełniący funkcję nieoficjalnej maskotki ruchu higienicznego, przekonał się o tym, gdy w roku 1854 jego kariera legła w gruzach wskutek oporu politycznego oraz prywatnych antypatii w kilku dzielnicach Londynu; dopiero kilka lat później, w 1858 roku, Wielki Smród ${ }^{47}$ otworzył możliwość wybudowania kompleksowego systemu kanalizacji w Londynie. Jednak największa trudność tkwiła być może w umysłach zwykłych ludzi: trzeba było ich przekonać, że środowiskowa wersja ochrony zdrowia publicznego, jaką im proponowano, warta była swojej ceny. Aby stało się to możliwe, należało - by użyć stwierdzenia Richarda L. Schoenwalda - „wytrenować miejskiego człowieka”48. Innymi słowy, konieczne było, by społeczeństwo dokonało ogromnego skoku mentalnego w zakresie osobistej dyscypliny niezbędnej do życia w nowoczesnych miastach. Catherine Gallagher nadaje temu przełomowi pewną wagę metafizyczną, którą „ciężko jest nam dzisiaj uchwycić” ${ }^{49}$.

Rozwój tego rodzaju przemian kulturowych ukazywać można między innymi w sztuce. W latach 30. i 40. XIX wieku środowisko miejskie było postrzegane jako do tego stopnia wstrętne, że stało to się jednym z wątków takich powieści jak Oliver Twist czy Samotnia ${ }^{50}$. To właśnie w nich została wykorzystana paradoksalna „atrakcyjność tego, co odpychające”, o której później pisał sam Charles Dickens ${ }^{51}$. Badacze literatury wskazują na to, że pisarze odzwierciedlali powszechną postawę ostrożności wobec środowiska, jaka utrzymywała się przez parę dekad, od lat 30. do 50. XIX wieku. Janice Carlisle potwierdza jednak, że literacka świadomość społeczna w końcu zaczęła się zmieniać52 . Dławiący smród piwnicy w Davenport z powieści Mary Barton Elizabeth Gaskell czy odór z Yeast Charlesa Kingsleya - dzieł opublikowanych w 1848 roku - zniknęły w utworach z lat 60. XIX wieku ${ }^{53}$. Do tego czasu udało się częściowo przejąć kontrolę nad nieczystościami i mogły nawet być one postrzegane jako potencjalne źródło dochodu, jak w Naszym wspólnym przyjacielu ${ }^{54}$. Co ciekawe, jak zauważył David Trotter, również malarze zaczęli usuwać wszelkie oznaki brudu, śmieci czy nieczystości ze swoich obrazów, wyrażając tym samym podzielany społecznie pogląd na właściwy temat nowoczesności ${ }^{55}$.

$[\ldots]$

Z chwilą, gdy myśl sanitarna się przyjęła, rozpoczął się stopniowy proces przechodzenia od tego, co John Simon nazwał „kloacznym miastem”, do miasta skanalizowanego ${ }^{56}$. W rzeczywistości zaczął się wraz z powołaniem w roku 1847 Metropolitan Sewers Commission [Metropolitalnej Komisji do spraw Kanalizacji] i towarzyszyło mu wiele kontrowersji. Trzy najważniejsze z nich dotyczyły następujących kwestii: czy rury kanalizacyjne są lepsze od kanałów zbudowanych z cegły, jaka jest optymalna średnica rur oraz czy kanały powinny być spłukiwane wodą ${ }^{57}$. W 1848 roku długość sieci kanalizacyjnej ułożonej z rur w całym kraju wynosiła zaledwie 167 
kilometrów, ale do roku 1854 wzrosła do 4184 kilometrów ${ }^{58}$. Mimo że w tym roku kariera Chadwicka oficjalnie się zakończyła, to właśnie jego koncepcja zyskała popularnośćs9. Na ironię zakrawa fakt, że to jeden z krytyków Chadwicka, Joseph Bazalgette, został ostatecznie odpowiedzialny $\mathrm{w}$ Londynie za wybudowanie - z sukcesem - zintegrowanych sieci kanalizacyjnych, ukształtowanych zgodnie z kolosalnym rozgałęzionym schematem inżynieriipodziemnej,ukończonych w 1875 roku $^{60}$. Umożliwiło to powstanie nowego typu usieciowionego urbanizmu, skomplikowanego pod względem organizacyjnym i drogiego w utrzymaniu ${ }^{61}$. Stał się on re-formowaną „naturą metropolitalną", która zastąpiła wcześniejsze, organiczne koncepcje ${ }^{62}$.

Kanalizacja była pierwszą siecią technologiczną, która ostatecznie została „nieodłączną częścią miasta”, a także „pośrednikiem umożliwiającym urzeczywistnianie się wiecznego procesu przemiany Natury w Miasto" ${ }^{3}$. Powstanie miasta skanalizowanego było równoznaczne z „agresywną modernizacją podziemnej przestrzeni”, wymagającej zarówno ściślejszej scentralizowanej kontroli, jak i spojrzenia biopolitycznego ${ }^{64}$. Intelektualne zaangażowanie w tym właśnie kierunku kosztem kilku innych opierało się na utylitarnej kalkulacji zanurzonej w wielkim skoku wiary: „Chadwick i jego współpracownicy odrzucili jako nieistotne kwestie zatrudnienia, pensji oraz wyżywienia, a skupili się na wodzie i brudzie, co doprowadziło do prawdopodobnie najważniejszej «technicznej poprawki» W historii”65.

Możliwe, że to właśnie tutaj zmaterializowała się wizja procesów obiegu metabolicznego, którego funkcjonowanie przedstawiano wcześniej wyłącznie nieformalnie ${ }^{66}$. Stało się to możliwe dzięki ulepszonej technologii rur, dzięki ciągłemu przepływowi wody pod ciśnieniem oraz dzięki czystej sile woli higienistów, rzucających publiczne światło na prywatną do tej pory kwestię wypróżniania. Wyłonienie się nowego sposobu poznawania miasta niosło ze sobą wiele konsekwencji. Jak pokazała Pamela K. Gilbert, planowanie kanalizacji grawitacyjnej oparte było na drobiazgowych i dokładnych badaniach topograficznych, tak więc mapowanie i odkrycie przestrzeni miejskiej zostało, przynajmniej częściowo, osiągnięte dzięki zainteresowaniu się brudem $^{67}$. W Londynie wybrano skalę kartograficzną, w której 1,5 metra odpowiadało 1,5 kilometra, i była to największa skala użyta do tej pory - do wykonania tego zadania zatrudniono 250 wojskowych mierniczych ${ }^{68}$.

Matthew Gandy słusznie postrzega kanały jako „jedne z najbardziej misternych i złożonych

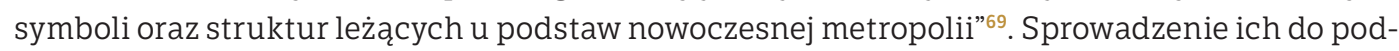
ziemi, do „miejskiego niesamowitego” [urban uncanny], było powiązane z niepokojami dotyczącymi przemieszczania i utraty orientacji. Kanały znalazły się na jednej z najostrzejszych granic pomiędzy środowiskiem a społeczeństwem. Były przestrzenią upodlenia i w powszechnej opinii umożliwiły zbiorową amnezję obejmującą cielesne odpadki ${ }^{70}$. Kanalizacja ma więc dla żyjącego na powierzchni społeczeństwa głównego nurtu charakter dialektyczny ${ }^{71}$ :

Podziemie wzbudza fascynację nie tylko dlatego, że zawiera wszystko to, co zakazane, ale też dlatego, że mieści to w sobie pod postacią niewyobrażalnie bogatego, choć nieokreślonego i odurzającego naparu z innych czasów, miejsc i sposobów bycia w świecie, a również dlatego, że wywar ten ukazuje kruchość jedności głoszonej przez świat na górze ${ }^{72}$. 
Skanalizowane miasto ugruntowało w krajobrazie ideologię radzenia sobie z nieuporządkowaną naturą ${ }^{73}$. Jednak w żadnym razie nie było to proste konstruowanie społeczne idei, reprezentacji oraz przestrzeni. Jak już widzieliśmy, materialność brudu trudno było skonceptualizować, a jego obecność wiążąca się z ryzykiem wymykała się poznaniu w swojej złożoności. Przede wszystkim technologie oraz funkcjonowanie kanalizacji były napastliwie kwestionowane, do tego nawet stopnia, że jej realizacje różniły się w zależności od miasta. Poprzez poskramianie i kontrolowanie wytworzono wiele nowych natur oraz subnatur ${ }^{74}$, które odpryskiwały w trakcie kolejnych uderzeń nowoczesności. Choć były to tylko odpryski i fragmenty natury podległej, nadal naturą pozostawały. Wysiłki, jakie podejmowało społeczeństwo wiktoriańskie, by sprzątać i oczyszczać, nigdy nie odpowiadały pokładanym w nich nadziejom, a w miastach nadal roiło się od życia nie-ludzkiego, tworzonego również przez naturę reintrodukowaną w warunkach kontrolowanych, na przykład w postaci parków miejskich, rosnących na poboczach dróg drzew, zoo i zwierząt towarzyszących ${ }^{75}$. To wszystko składało się na „permanentny i nieredukowalny pluralizm" natur w rozumieniu wprowadzonym przez Zygmunta Baumana ${ }^{76}$

Raymond Williams postrzegał proces urbanizacji jako kluczowy element przekształcania natury poprzez relacje społeczne, co David Harvey następnie rozwinął, ukazując, że relacje społeczne są ustanawiane i reprodukowane w wyniku przekształceń ekologicznych zachodzących w mieście ${ }^{77}$. Znaczenia natury są oczywiście złożone, ale - jak się wydaje - kanalizacja stanowiła punkt węzłowy ponownego wyobrażania sobie i re-formowania znaczeń, które złożyły się na nasze nowoczesne sposoby myślenia o tym, czym jest lub czym powinno być miasto. Miasta pozbawione kanalizacji coraz częściej oceniano jako gorsze lub też podawano w wątpliwość ich status miasta prawdziwego.

Oczywiście to nie wtedy rozpoczął się podział na naturę i kulturę, jednak okres od połowy do końca XIX wieku stanowi w tym kontekście moment przełomowy ${ }^{78}$. Noel Castree pisze o hybrydzie: socjonaturze ${ }^{79}$. Jego teza częściowo ma charakter filozoficzny, ponieważ argumentuje on, że możliwe stało się wypracowanie takich relacyjnych sposobów namysłu, które obejmowałyby elementy zarówno środowiska, jak i społeczeństwa uwikłane w sieci łączące aktorów. Odsuwając na bok popularne w żargonie naukowym sformułowania, takie jak aktor-sieć czy asamblaże ${ }^{80}$, zauważyć należy imponujący rozmach podobnych stanowisk posthumanistycznych. W innym miejscu Castree głosi jednak, że temat hybryd kultury i natury zyskał popularność wśród naukowców i szerokiej publiczności w odpowiedzi na rosnącą świadomość, iż wpływ nowoczesności - z powodu zanieczyszczeń, emisji gazów cieplarnianych czy spadku bioróżnorodności - jest szkodliwy do tego stopnia, że zagraża przyszłości naszej planety. Ponowne odkrywanie powiązań między społeczeństwem i naturą oraz wytwarzanie nowych wersji utraconych lub wyniszczonych natur stało się więc głównym tematem zajmującym entuzjastów ekologii.

W naszej wersji tej historii tematy te zostały znów cofnięte do XIX wieku. Skoro w ostatnich latach to postmodernizm upoważnił nas do przemyślenia i umacniania różnicy oraz hybrydyczności, co można powiedzieć o wczesnych dekadach nowoczesnych sposobów myślenia o zagrożeniach środowiskowych? Zanieczyszczone i zdegradowane środowiska były elementem zarówno miast wiktoriańskich, jak i ich okolic, jednak wywoływały wtedy zupełnie inną reakcję. Skupiano się na wyodrębnieniu namysłu o naturze, by następnie produkować i reprodukować go na takie sposoby, które mogły zostać dostosowane do panujących ówcześnie wzorców ideologicznych. W tym sensie „wielkie oddzielenie” zapoczątkowane w latach 30. i 40. XIX wieku było lustrzanym odbiciem dzisiejszego ruchu na rzecz ekomiast.

Rozwijanie tego argumentu wymaga nieco ostrożności. Możemy przywracać uregulowane biegi rzek do ich „naturalnego” stanu oraz usuwać zabezpieczenia brzegu morskiego, aby odtworzyć naturalną równowagę pomiędzy erozją i depozycją, jednak nikt się nie domaga, by miejskie ulice znów pokryte były końskim łajnem lub aby w centrach miast otwierano rzeźnie. Niektóre ze zjawisk organicznego premodernizmu zostały trwale usunięte, a duża część współczesnego ruchu na rzecz ekologizacji miast jest w swojej ideologii i praktyce równie kontrolowana oraz kontrolująca jak wiktoriański ruch higieniczny.

„Wielkie oddzielenie” nie było zachodzącą z dnia na dzień rewolucją, lecz stanowiło powolny proces, który w zależności od miasta miał różne tempo i charakteryzował się innym stopniem kompletności zmian. W przypadku Londynu potrzeba było kilku dekad, licząc od lat 40. XIX wieku, by przełom reprezentowany przez budowę kanalizacji ugruntował się w umysłach 
ludzi i krajobrazie. Zwierzęce odchody zaczęły tracić na wartości w drugiej połowie XIX wieku, wynikało to jednak tak ze słabnącego popytu, jak ze wzrostu liczby koni. Wreszcie w pierwszej dekadzie XX wieku dominacja transportu konnego w miastach została znacznie osłabiona przez wprowadzenie silnika spalinowego. Przedsiębiorstwa zajmujące się produkcją zwierzęcą zaczęły ulegać poważnym naciskom o bezpośredniej lub pośredniej motywacji sanitarnej; możemy powiedzieć, że już przed I wojną światową zarówno zwierzęta, które wykorzystywano do produkcji żywności, jak i rozmaite zakłady przetwarzające produkty uboczne pochodzenia zwierzęcego przestano traktować w sensie lokalizacji jako „miejskie”.

„Wielkie oddzielenie” oznaczało zmaterializowanie się ontologicznego rozłamu, który powstał w XVIII wieku, ale przeistoczył się z postaci zalążkowej dopiero na początku wieku XIX przy wtórze jednej z najpotężniejszych melodii: pieśni higieny. Jej niezwykła moc sprawiła, że naród dał się przekonać do inwestowania ogromnych sum w teorię medyczno-środowiskową, która - prawdę mówiąc - nie miała dobrze ugruntowanego uzasadnienia epidemiologicznego. Mimo to zarówno przyczyniła się do fizycznej przemiany przestrzeni miejskiej, jak i wywołała prawdziwe tsunami intelektualnego entuzjazmu, porównywalnego z paroma zaledwie podobnymi przypadkami w historii. Tak oto narodziły się nowe kierunki myślenia o środowisku, a w kontekście szerzej zakrojonego planu opanowania natury oddzielenie zwierząt od kultury miejskiej wydaje się niemal sprawą poboczną.

Przełożyła Justyna Schollenberger

\section{PRZYPISY}

1 J. Culler, Junk and Rubbish: a Semiotic Approach, „Diacritics” 1985, nr 15(3), s. 4

2 M. Douglas, Czystość i zmaza, przeł. M. Bucholc, Warszawa 2007, s. 148.

3 Jak zauważa Ben Campkin, kłóci się to ze strukturalistycznym uniwersalizmem Douglas. B. Campkin Degradation and Regeneration: Theories of Dirt and the Contemporary City, w: B. Campkin, R. Cox (red.), Dirt: New Geographies of Cleanliness and Contamination, London 2007

4 Zakładam, że brud i nieczystości są względem siebie synonimiczne, choć Douglas traktowała je oddzielnie. N. Gregson, M. Crang, Materiality and Waste: Inorganic Vitality in a Networked World, "Environment and Planning" 2010, nr A 42, s. 1026-1032.

5 W całym artykule autor odnosi się przede wszystkim do Europy Zachodniej [przyp. red. pol.].

6 P. Atkins, Liquid Materialities: A History of Milk, Science and the Law, Farnham 2010

7 L. Brown, Fables of Modernity: Literature and Culture in the English Eighteenth Century, Ithaca, NY 2001; S. Gee, Making Waste: Leftovers and the Eighteenth-Century Imagination, Princeton, NJ 2010.

8 M. Gold, A History of Nature, w: D. Massey, J. Allen (red.), Geography Matters!, Cambridge 1984, s. 12-33.

9 A. Corbin, We władzy wstrętu. Społeczna historia poznania przez węch: od odrazy do snu ekologicznego, przeł. A. Siemek, Warszawa 1998.

10 P. Stallybrass, A. White, The Politics and Poetics of Transgression, Ithaca, NY 1986.

11 P.K. Gilbert, Medical Mapping: the Thames, the Body, and Our Mutual Friend, w: W.A. Cohen, R. Johnson (red.), Filth: Dirt, Disgust and Modern Life, Minneapolis 2005, s. 79

12 Więcej na temat niepokoju pisze David Trotter, The New Historicism and the Psychopathology of Everyday Modern Life, w: W.A. Cohen, R. Johnson (red.), Filth: Dirt, Disgust..., dz. cyt.

13 C. Hannaway, Environment and Miasmata, w: W.F. Bynum, R. Porter (red.), Companion Encyclopedia of the History of Medicine, London 1993.

14 D.S. Barnes, Confronting Sensory Crisis in the Great Stinks of London and Paris, w: W.A. Cohen, R. Johnson (red.), Filth: Dirt, Disgust..., dz. cyt.

15 Ch. Hamlin, Public Health and Social Justice in the Age of Chadwick: Britain, 1800-1854, Cambridge 1998 S. Halliday, The Great Stink of London: Sir Joseph Bazalgette and the Cleansing of the Victorian Capital, Strand 1999; D. Barnes, The Great Stink of Paris and the Nineteenth-Century Struggle Against Filth and Germs, Baltimore 2006; D. Inglis, Sewers and Sensibilities: the Bourgeois Faecal Experience in the Nineteenth-Century City, w: A. Cowan, J. Steward (red.), The City and the Senses: Urban Culture since 1500, Aldershot 2007.

16 J. Copland, A Dictionary of Practical Medicine, t. 1, Boston 1834-1856, s. 23.

17 E. Chadwick, Report on the Sanitary Conditions of the Laboring Population of Great Britain, London 1843.

18 R.E. Lougy, Filth, Liminality, and Abjection in Charles Dickens' 'Bleak House', "ELH” 2002, nr 69, s. 473-500. 
19 F. Braudel, Kultura materialna, gospodarka i kapitalizm XV-XVIII wiek, t. 1, przeł. M. Ochab, P. Graff, Warszawa 1992, s. 399.

20 M. Thompson, Rubbish Theory: The Creation and Destruction of Value, Oxford 1979

21 K. Dickens, Nasz wspólny przyjaciel, przeł. T.J. Dehnel, Warszawa 1971.

22 H. Mayhew, London Labour and the London Poor, t. 2, London 1851. Co ciekawe, David Pike dostrzega w śmieciarzach przewrotne wyzwanie rzucone głównemu nurtowi społeczeństwa, tak bardzo na bakier byli z gwałtownie racjonalizującym się, nowoczesnym miastem. Por. D.L. Pike, Subterranean Cities: The World Beneath Paris and London, 1800-1945, Ithaca, NY 2005, s. 57. Zob. także J. Scanlan, In Deadly Time: the Lasting on of Waste in Mayhew's London, "Time and Society" 2007, nr 16, s. 205-222.

23 R. Williams, The Country and the City, London 1973

24 A.S. Wohl, Endangered Lives: Public Health in Victorian Britain, London 1983.

25 D. Harvey, Justice, Nature and the Geography of Difference, Cambridge, MA 1996

26 J. von Liebig, Organic Chemistry in Its Applications to Agriculture and Physiology, London 1840.

27 J.B. Foster, Marx's Theory of Metabolic Rift: Classical Foundations for Environmental Sociology, "American Journal of Sociology" 1999, nr 105, s. 366-405

28 E. Mårald, Everything Circulates: Agricultural Chemistry and Recycling Theories in the Second Half of the Nineteenth Century, "Environment and History” 2002, nr 8, s. 65-84; tegoż, Our Finest Gold: Agrarian Perspectives on Urban Technology from the Mid 19th Century to Present-Day Ecocyclical Society, "Progress in Industrial Ecology" 2006, nr 3, s. 393-407.

29 S.L. Dana, A Muck Manual for Farmers, Lowell 1842; F. Falkner, The Muck Manual, London 1843; A. Müller, Gödselboken eller grunderna för gödselämnenas behandling i städer och på landet, Stockholm 1860.

30 Por. W.A. Cohen, R. Johnson (red.), Filth: Dirt, Disgust..., dz. cyt. Według Dany Simmons „w tym okresie ekskrementy stały sie głównym tematem dla francuskiej odmiany antykapitalizmu". D. Simmons, Waste Not, Want Not: Excrement and Economy in Nineteenth-Century France, "Representations" 2006, nr 96, s. 75

31 G. Davison, The City as a Natural System: Theories of Urban Society in Early Nineteenth-Century Britain w: D. Fraser, A. Sutcliffe (red.), The Pursuit of Urban History, London 1983.

32 M. Allen, Cleansing the City: Sanitary Geographies in Victorian London, Athens, OH 2008, s. 15.

33 A. Waters-Bayer, Living with Livestock in Town "Urban Agriculture Magazine" 2000, nr 1; A. Santandreu, G. Castro, F. Ronca, Urban Pig Fin Irregular Settlements in Uruguay, "Urban Agriculture Magazine" 2000, nr 2, s. 29-31; Food and Agriculture Organization, Growing Greener Cities Rome, FAO 2010.

34 Więcej na ten temat zob. P. Atkins, The Intra-Urban Milk Supply of London, Circa 1790-1914, "Transactions of the Institute of British Geographers" 1977, nowa seria 2, s. 383-399; tegoż, The Milk Trade of London, c. 1790-1914, niepublikowana rozprawa doktorska, University of Cambridge 1978; tegoż, Is it Urban? The Relationship Between Food Production and Urban Space in Britain, 1800-1950, w: M. Hietala, T. Vahtikar (red.), The Landscapes of Food: The Food Relationship of Town and Country in Modern Times, Helsinki 2003.

35 T. Beames, The Rookeries of London, London 1852, s. 213.

36 G.R Sims, How the Poor Live, London 1883, s. 42

37 Obecnie Ceredigion [przyp. red. pol.].

38 G. Francis-Jones, Cows, Cardis and Cockneys, Talybont 1984; E. Jones, The Early Nineteenth Century oraz Flow and Ebb, w: tenże (red.), The Welsh in London, 1500-1900, Cardiff 2001.

39 W. Youatt, Cattle: Their Breeds, Management and Diseases, London 1834, s. 255; E. Ballard, Report in Respect of the Inquiry as to Effluvium-Nuisances Arising in Connexion with Various Manufacturing and Other Branches of Industry, Part I, Sixth Annual Report of the Local Government Board. 1876-77. Supplement Containing the Report of the Medical Officer for 1876, London 1882, s. 134, 135; P. Mathias, Agriculture and the Brewing and Distilling Industries in the Eighteenth Century, "Economic History Review” 1952, nr 5, s. 249-257.

40 J. Mullaly, The Milk Trade in New York and Vicinity, New York 1853, s. 43-46.

41 D.D. Biehler, Flies, Manure, and Window Screens: Medical Entomology and Environmental Reform in Early Twentieth-Century US Cities, „Journal of Historical Geography” 2010, nr 36, s. 68-78.

42 W.H. Hamer, Flies and Vermin: Report by the Medical Officer Presenting Reports by Dr Hamer, Medical Officer (General Purposes) on Nuisance from Flies and on the Seasonal Prevalence of Vermin in Common Lodging Houses, London 1910; J. Niven, Summer Diarrhoea and Enteric Fever, "Proceedings of the Royal Society of Medicine (Epidemiological Section)" 1910, nr 3; Ch.G. Hewitt, The House-fly, Musca Domestica Linn: Its Structure, Habits, Development, Relation to Disease and Control, Cambridge 1914.

43 N. Morgan, Infant Mortality, Flies and Horses in Later-Nineteenth-Century Towns: a Case Study of Preston "Continuity and Change" 2002, nr 17, s. 97-132.

44 D. Dwork, War is Good for Babies and Other Young Children, London 1987, s. 45-49; P. Atkins, White Poison: the Health Consequences of Milk Consumption, "Social History of Medicine" 1992, nr 5, s. 207-227.

45 P. Atkins, The Intra-Urban Milk Supply..., dz. cyt., s. 383-399. 
46 Termin "miasto bakteriologiczne" zaproponował Matthew Gandy. Por. M. Gandy, The Bacteriological City and Its Discontents, „Historical Geography” 2006, nr 34, s. 14-25; tenże, Urban Nature and the Ecological Imaginary, w: N. Heynen, M. Kaika, E. Swyngedouw, In the Nature of Cities, London 2006.

47 Chodzi o katastrofe ekologiczna, do której doszło w Londynie w miesiącach letnich 1858 roku. Utrzy mujące się upały doprowadziły do dużego obniżenia poziomu wody w Tamizie, wskutek czego zostały odsłonięte znajdujące się tam nieczystości pochodzące z przestarzałego systemu kanalizacyjnego. Pod wpływem wysokich temperatur smród wydzielany przez rozkładające się ścieki stał się nie do wytrzymania i sparaliżował życie miasta. Wydarzenie to przekonało ostatecznie władze Londynu do całkowitej przebudowy kanalizacji [przyp. red. pol.].

48 R.L. Schoenwald, Training Urban Man: a Hypothesis About the Sanitary Movement, w: H.J. Dyos, M. Wolff (red.), The Victorian City: Images and Realities, London 1973.

49 C. Gallagher, The Bio-economics of Our Mutual Friend, w: M. Feher (red.), Fragments for a History of the Human Body, Part Three, New York 1989, s. 359.

50 Ch. Dickens, Oliver Twist, przeł. K. Surówka, Kraków 2005; tenże, Samotnia, przeł. T.J. Dehnel, Warszawa 1975.

51 J. Forster, The Life of Charles Dickens, London 1872-1874; P. Collins, Dickens and London, w: H.J. Dyos, M. Wolff (red.), The Victorian City..., dz. cyt., s. 537

52 J. Carlisle, Common Scents: Comparative Encounters in High-Victorian Fiction, Oxford 2004, s. 15

53 E. Gaskell, Mary Barton, przeł. K. Tarnowska, Warszawa 1958; Ch. Kingsley, Yeast: A Problem, London 1849.

54 Ch. Dickens, Nasz wspólny przyjaciel, dz. cyt.

55 D. Trotter, Cooking with Mud: The Idea of Mess in Nineteenth-Century Art and Fiction, Oxford 2000, s. 324, 325

56 A.S. Wohl, Endangered Lives: Public Health in Victorian Britain, London 1983, s. 89

57 Ch. Hamlin, Edwin Chadwick and the Engineers, 1842-1854: Systems and Antisystems in the Pipe-And-Brick Sewers War, "Technology and Culture" 1992, nr 33, s. 680-709; tenże, Public Health and Social Justice in the Age of Chadwick: Britain, 1800-1854, Cambridge 1998.

58 W Paryżu długość sieci kanalizacyjnej wynosiła 65 kilometrów w roku 1850, 210 w 1850, a 560 w 1870. Por. R.H. Williams, Notes on the Underground: an Essay on Technology, Society, and the Imagination, Cambridge 2008.

59 S.E. Finer, The Life and Times of Sir Edwin Chadwick, London 1952, s. 451.

60 A.F. Green, The Problem of London's Drainage, "Geography" 1956, nr 41; S. Halliday, The Great Stink of London..., dz. cyt. Por. także G. Knaebel, Historical Origins and Development of a Sewerage System in a German City: Bielefeld, 1850-1904, w: J.A. Tarr, G. Dupuy (red.), Technology and the Rise of the Networked City in Europe and America, Philadelphia 1988; J.A. Tarr, Sewerage and the Development of the Networked City in the United States, 1850-1930, w: J.A. Tarr, G. Dupuy (red.), Technology and the Rise..., dz. cyt.

61 S. Graham, S. Marvin, Splintering Urbanism: Networked Infrastructures, Technological Mobilities and the Urban Condition, London 2001.

62 M. Gandy, Rethinking Urban Metabolism: Water, Space and the Modern City, "City" 2004, nr 8, s. 363-379.

63 M. Kaïka, E. Swyngedouw, Fetishizing the Modern City: the Phantasmagoria of Urban Technological Networks, „International Journal of Urban and Regional Research" 2000, nr 24, s. 1.

64 M. Allen, Cleansing the City..., dz. cyt., s. 42

65 Ch. Hamlin, Public Health..., dz. cyt., s. 13. Chadwick w trakcie wprowadzania prawa biedoty (Poor Law) nabrał pewności, że nędza nie była przyczyną zarazy. Nawrócił się na nowe wyznanie ruchu higienicznego w 1838 roku.

66 E. Swyngedouw, Circulations and Metabolisms: (Hybrid) Natures and (Cyborg) Cities, "Science as Culture" 2006, nr 15, s. 114.

67 P.K. Gilbert, Medical Mapping..., dz. cyt., s. 79

68 P. Dobraszczyk, Mapping Sewer Spaces in Mid-Victorian London, w: B. Campkin, R. Cox (red.), Dirt: New Geographies Dirt..., dz. cyt.

69 M. Gandy, The Paris Sewers and the Rationalization of Urban Space, "Transactions of the Institute of British Geographers" 1999, nowa seria 24, s. 24

70 G. Hawkins, Down the Drain: Shit and the Politics of Disturbance, w: G. Hawkins, S. Muecke (red.), Culture and Waste: The Creation and Destruction of Value, Lanham, MD 2003.

71 D. Donald, "Beastly Sights": the Treatment of Animals as a Moral Theme in Representations of London c. 1820-1850, w: taż (red.), The Metropolis and Its Image: Constructing Identities for London, c. 1750-1950, Cambridge 1999.

72 D.L. Pike, Subterranean Cities..., dz. cyt., s. 97.

73 S. Oliver, The Thames Embankment and the Disciplining of Nature in Modernity, "Geographical Journal" 2000 , nr 166, s. 227-238. 
74 Zob. m.in. E. Rybicka, Biopolis - przyroda i miasto, „Teksty Drugie” 2018, nr 2, s. 70 i n.

75 N. Green, The Spectacle of Nature: Landscape and Bourgeois Culture in Nineteenth-Century France, Manchester 1990; M. Gandy, Urban Nature..., dz. cyt.

76 Z. Bauman, Czy istnieje postmodernistyczna socjologia?, przeł. B. Baran, Współczesne teorie socjologiczne, t. 2, wybór i oprac. A. Jasińska-Kania, L.M. Nijakowski, J. Szacki, M. Ziółkowski, Warszawa 2006, s. 795

77 D. Harvey, Justice, Nature and the Geography of Difference, Cambridge 1996, s. 94.

78 James Winter wskazuje, że w XIX wieku wskutek wycofania się przemysłu i odpływu ludności tereny wiejskie nabierały coraz bardziej prowincjonalnego charakteru i coraz cześciej powracano na nich do rolnictwa. J. Winter, Secure from Rash Assault: Sustaining the Victorian Environment, Berkeley 1999.

79 N. Castree, Geographies of Nature in the Making, w: K. Anderson, M. Domosh, S. Pile, N. Thrift (red.), Handbook of Cultural Geography, London 2003; tegoż, Nature, London 2005. Zob. także: S. Whatmore, Hybrid Geographies: Natures, Cultures, Spaces, London 2002; S. Hinchliffe, Geographies of Nature: Societies, Environments, Ecologies, London 2007. [W polskojęzycznej literaturze przedmiotu terminem "socjonatura" posługuje się m.in. Ewa Rewers, Humanistyki wobec koncepcji „kulturynatury”, „Teksty Drugie” 2017, nr 1, s. 171 - przyp. red. pol.].

80 Por. m.in. B. Latour, Splatając na nowo to, co społeczne, przeł. A. Derra, K. Abriszewski, Kraków 2010 (przyp. red. pol.) 



\section{Karolina Wróbel-Bardzik}

\section{Dystans i oddzielenie. Konie oraz zwierzęta hodowlane w Warszawie na przełomie XIX i XX wieku}

on jaki jest, każdy widzi” - stwierdził Benedykt Chmielow-
ski, autor Nowych Aten, uznawanych za jedną z pierwszych
polskich encyklopedii. Zdanie to weszło do użycia w języ-
ku polskim na określenie czegoś oczywistego, o czym nie warto dyskutować. Funkcjonuje ono jako powiedzenie, odnosi się do konia jako gatunku jednorodnego, ujmowanego w kategoriach ogólnych. Z perspektywy studiów nad zwierzętami konie mają jednak indywidualne charaktery zależne nie tylko od konkretnej rasy - na ich usposobienie wpływają różnorodne doświadczenia, odmienne interakcje międzygatunkowe oraz sposoby traktowania ich przez ludzi. Nie bez znaczenia są także warunki panujące w stajniach, rodzaj wykonywanej przez nie pracy, choroby i lokalne epizootie czy działania służące ochronie zwierząt. Warto także zauważyć, że wśród teoretycznych i metodologicznych wyzwań, przed jakimi stają badacze animal studies, niewątpliwie ważne pozostaje zagadnienie dotyczące tego, czy zwierzęta „mają historię", skoro uznaje się, że nie są obdarzone świadomością procesu historycznego i periodyzacji dziejów. Ich życie było jednak dalece warunkowane przemianami społeczno-gospodarczymi, które rozstrzygały o ich losach lub też odwrotnie - one same wpływały na kształtowanie biegu zdarzeń, pełniły sprawczą rolę w relacji z ludźmi ${ }^{1}$.

Szczególnie interesująca wydaje się miejska historia koni, a także zwierząt hodowlanych od połowy XIX do początku XX wieku, kiedy to najpierw obserwować można znaczny wzrost ich liczby w wielu miastach europejskich, a na przełomie wieków z kolei ich stopniowe znikanie. Proces ten opisują liczne publikacje naukowe, które koncentrują się wokół funkcji zwierząt w ówczesnych dyskusjach o modernizacji i higienizacji, ich negatywnej waloryzacji w mieście, gdy zaczynają sygnować tak zwane zapóźnienie cywilizacyjne oraz być postrzegane jako tam niechciane. W tym przypadku zwierzęta odgrywają istotną rolę, stają się barometrem zmian ich obecność lub nieobecność wyznacza status i poziom rozwoju miejskiego.

W polskiej literaturze naukowej brakuje jednak opracowań problematyzujących rolę i miejsce zwierząt w miastach z perspektywy wiedzy o przeszłości. Zjawisko to omówione zostanie więc na przykładzie Warszawy. Ramę odniesienia wyznaczają natomiast teksty badaczy rekonstruujących zmiany na podstawie wielkich stolic europejskich, Londynu czy Paryża. To ostatnie miasto stanowi zresztą kontekst porównawczy dla Warszawy w prasie z końca XIX i początku XX wieku. Zasadnicze procesy zaobserwowane przez historyków w dużym stopniu są zbieżne z tymi w polskim kręgu kulturowym mimo oczywistych dystynkcji uwzględniających specyfikę miasta 
środkowoeuropejskiego. Należałoby również wskazać na różnice w polskich miastach w okresie pozaborowym - Polska nie była bowiem jednolita pod względem kulturowym, inaczej przebiegały także miejskie procesy modernizacyjne ${ }^{2}$. Rytm zmian mogł być zatem odmienny, ale w węzłowych punktach daje się mimo to zauważyć elementy wspólne.

\section{Zwierzęta w dziewiętnastowiecznej Warszawie}

Do przestrzeni zwierząt gospodarskich w dziewiętnastowiecznym mieście zaliczyć można stajnie, obory, krowiarnie, chlewnie czy rzeźnie. Te ostatnie w Warszawie były usytuowane między innymi na Rybakach, Solcu i Pradze przy ulicy Krowiej. Podmiejskie natomiast na Powązkach, Grochowie, Pelcowiźnie i Ochocie. W mieście znajdowały się także pastwiska, o czym możemy przeczytać chociażby we wspomnieniach Józefa Galewskiego z końca XIX wieku. W sugestywny sposób opisywał on teren położony wzdłuż ulicy Karowej, nieopodal Krakowskiego Przedmieścia: „W tej posesji było jak na głuchej prowincji lub na wsi: drzewa, trawa, nawet i źródło. Krowy się tam pasły niczym na polu. Istna wiejska sielanka! Chodziło się tam co dzień po prawdziwe mleko od prawdziwej krowy lub na świeże powietrze”3. Choć obraz ten przywołuje scenerię charakterystyczną dla wiejskiego podwórza, należałoby powiedzieć, że paradoksalnie - jest ona także jak najbardziej miejska. Éric Baratay, francuski historyk, podejmujący próbę oddania w swoich publikacjach punktu widzenia zwierząt, zauważa, że doświadczenie krów w XIX wieku w Europie wyznaczał rozwój przemysłu mleczarskiego i konwersja mleczna, oznaczająca zwiększenie produkcyjności zwierząt, oraz trwające mniej więcej do okresu międzywojennego zamknięcie ich w miejskich oborach. Intensywna urbanizacja i wzrost liczby ludności sprawiały, że miasta były „epicentrami zapotrzebowania na mleko”. Z kolei Peter Atkins stwierdza, że w XIX wieku podział na wieś i miasto nie był dość jednoznaczny, podobnie jak koncepcja tego, co stanowi o istocie miejskości, w związku z czym zwierzęta i produkowane przez nie zanieczyszczenia były stałym elementem miasta, „konstytutywnym dla «urb-an-imalizmu»", stanowiącego rodzaj zurbanizowanej natury. Od połowy XIX wieku zachodziły jednak stopniowe zmiany w tym zakresie, które zyskały na wyrazistości pod koniec stulecia. Wówczas zwierzęta gospodarskie zaczynały być traktowane jako „nie na swoim miejscu”. Przytoczony fragment wspomnień Galewskiego dotyczący Warszawy zdaje się zaświadczać już o obecności myślenia w kategoriach dychotomicznych w odniesieniu do miasta i wsi.

W prasie wskazywano na jeszcze inny kontekst obecności zwierząt gospodarskich w mieście i pisano o całych stadach przepędzanych ulicami Warszawy. W jednym z doniesień z lat 80. XIX wieku czytamy, że w ówczesnej Alei Jerozolimskiej, na odcinku między Nowym Światem a ulicą Szpitalną, można było ujrzeć takie „widowisko”: „Całą szerokością chodnika maszerowała sobie trzoda świń, może z paruset sztuk złożona, w akompaniamencie kilku poganiaczy". Zdziwienie obserwatora wywołał fakt, że prowadzono je chodnikiem, a nie jezdnią, na co zupełnie nie reagowali mieszkańcy, „sami potulnie maszerując środkiem ulicy”. O ile w artykule odnotowana została obojętność ludzi, o tyle na początku XX wieku obrazy te były wciąż aktualne, ale budziły już zastrzeżenia. Informuje o tym między innymi Jerzy S. Majewski, przytaczający treści z „Kuriera Porannego” z 1912 roku, gdzie żalono się na stada liczące nawet około 100 wołów, prowadzonych od mostu Kierbedzia do rzeźni na Solcu: „Na placu Trzech Krzyży ryczące woły powodowały korki i zamieszanie. Zatrzymywały się tramwaje, elegancko ubrane damy uskakiwały przed zwierzętami gnającymi Żurawią lub Nowogrodzką. Podobne sceny powtarzały się na skrzyżowaniu z Marszałkowską"”.

Konie, ze względu na pracę w transporcie, były stale obecne i widoczne w dziewiętnastowiecznym mieście, miały przez to większy wpływ na kształtowanie przestrzeni - odmiennie niż w przypadku losu zwierząt przeznaczonych na rzeź, które jednak szybko znikały z miasta. Choć oczywiście należy zauważyć, że żywot koni miejskich też był krótki, zwłaszcza tych ciągnących wozy omnibusowe oraz tramwajowe. Zwierzęta, nadmiernie eksploatowane, były często wyniszczone i wychudzone. Baratay nazywa konie pracujące w miastach przy transporcie zbiorowym czy w kopalniach „proletariuszami”, krowy zaś „niewykwalifikowanymi robotnicami”. Inny zaś badacz, Jason Hribal, stawia pytanie, czy zwierzęta można zaliczyć do klasy robotniczej. Udziela na to pozytywnej odpowiedzi i zaznacza, że takie podejście stanowi 
niewątpliwie wyzwanie dla dotychczasowej historii pracy [labor history] jako subdyscypliny naukowej ${ }^{9}$. Jak stwierdza, dziewiętnastowieczne miasto, analizowane przez niego na przykładzie brytyjskim, przynosi coraz większe uzależnienie od człowieka zwierząt zamkniętych w stajniach i oborach. Stopniowo przestawały one funkcjonować poza kontekstem przypisanej im funkcji i wykonywanej pracy. To w gruncie rzeczy historia ich wywłaszczenia, były bowiem traktowane jak niewolnicy, a za swoją pracę nie dostawały żadnej rekompensaty. Według Hribala zwierzęta stanowiły ten sam co ludzie element systemu kapitalistycznego, w którym istotna stawała się akumulacja zysków. Nadużycia wobec ludzi i zwierząt były ze sobą połączone. Wyzysk w samych zaś miastach nie tylko pozostawał bardziej zauważalny, lecz także gwałtownie narastał wraz z urbanizacją ${ }^{10}$.

Szczególnie los koni był ściśle powiązany z rozwojem miast. W samej Warszawie łatwiej zrekonstruować skalę ich obecności, chociażby ze względu na dostępność odpowiednich zestawień statystycznych. Według historyka Łukasza Sobechowicza cały wiek XIX oznaczał stały, systematyczny wzrost liczby koni w mieście, proporcjonalnie do przyrostu ludności, przy czym najintensywniejsze przyspieszenie tego procesu notowano od połowy stulecia. O ile w 1803 roku było około 1800 koni, o tyle sto lat później już 14 000. Zależność między liczbą ludności a koni w mieście całkowicie zaniknęła po zakończeniu I wojny światowej, kiedy zwierzęta przestały stanowić jedyny środek transportu ${ }^{11}$. Rozpatrywane przez badacza dane dotyczą koni osób prywatnych, zarządu tramwajów miejskich, straży pożarnej i służb oczyszczania miasta, nie obejmują natomiast tych należących do wojska, policji czy wy-

Wyjaśnienie, że konie usuwano stopniowo $z$ miast, ponieważ zastępowały je tramwaje elektryczne, jest słuszne, ale niewystarczajq̨ce. Za Soppelsq można powiedzieć, że przyczyniły się do tego nie tylko usprawnienia $w$ transporcie, lecz także wspomniany wcześniej rozwój ruchów na rzecz praw zwierząt oraz wzrost wiedzy z zakresu higieny [...]. sokich urzędników, jako że nie wpływały bezpośrednio na funkcjonowanie Warszawy ${ }^{12}$. Pominięta została także praca koni w przemyśle i procesie produkcyjnym, ponieważ w XIX wieku nie odgrywała ona już większej roli, z pewnością nie w drugiej połowie stulecia - można przypuszczać, że mechanizacja zmniejszyła ich eksploatację i wyzysk w tym zakresie. W mieście stanowiły one głównie siłę pociągową w transporcie osób oraz towarów ${ }^{13}$.

W grudniu 1866 roku na ulicach Warszawy pojawiły się, zastępując omnibusy, pierwsze tramwaje konne poruszające się po szynach. Oficjalnie były określane jako „Kolej Konna Żelazna”, potem już jako „Kolej Konna”. Koncesję na wybudowanie linii i potrzebnej infrastruktury otrzymało Główne Towarzystwo Dróg Żelaznych Rosyjskich, następnie zaś, w latach 1881-1883, Towarzystwo Belgijskie rozbudowało sięć o kolejne siedem linii. W latach 80. po Warszawie jeździło 100 wagonów, dziennie pracowało natomiast 400 koni $^{14}$. Stajnie znajdowały się obok trzech zajezdni - Stacji Głównej przy ulicy Sierakowskiej i dwóch pomocniczych przy ulicy Wileńskiej na Pradze i na Mokotowie. W tej ostatniej funkcjonowały także lecznica dla koni, kuźnia oraz warsztaty. W jej pobliżu zostały ponadto otworzone restauracja i mleczarnia. Na przełomie wieku, według danych z 1901 roku, stajnie trzech zajezdni mieściły łącznie aż 646 koni ${ }^{15}$. W Warszawie były ponadto stajnie służb porządkowych, straży pożarnej czy pogotowia. Także mieszkańcy utrzymywali swoje konie wraz z bryczkami, wozami i platformami. Co ciekawe, w tym okresie aż 90 procent koni w mieście należało do osób prywatnych ${ }^{16}$. 
Obecność pojazdów konnych w komunikacji miejskiej wiązała się z licznymi problemami. Stanisław Milewski rekonstruuje kwestię ruchu ulicznego za doniesieniami prasowymi między innymi z drugiej połowy XIX i pierwszych dziesięcioleci XX wieku. Miasto z końca stulecia było bardzo zatłoczone, jednocześnie trudności, z jakimi się borykano, to brak przestrzegania podstawowych przepisów drogowych - jeżdżono wozami i dorożkami zbyt szybko i brawurowo, inne pojazdy oraz nie stosowano się do zasad ruchu prawostronnego, po zmroku nie zapalano latarek ${ }^{17}$. Co ciekawe, podkreślano przy tym specyfikę krajową, z prasy wyłaniają się częste porównania do standardów zachodnich. Felietoniści warszawscy rozpisywali się o negatywach, między innymi Edward Leo, mieszkający w Berlinie, a podróżujący także do Brukseli i Paryża, tak w 1874 roku wypowiadał się o wiejskich wozach na ulicach Warszawy: „U nas przeciwnie, każdy furman, każdy chłop wiozący drzewo uważa się za pana ulicy; zdaje mu się, że jedzie przez pola i dlatego trzyma się środka"18. Maurycy Orgelbrand, bywający w wielu stolicach europejskich, dawał za wzór pod względem regulacji ruchu drogowego Paryż, Berlin i Wiedeń. W odpowiedzi na liczne wypadki drogowe (dziennie od trzech do nawet jedenastu, w skali roku co najmniej tysiąc) postulował wprowadzenie dowodów z egzaminów z jazdy ${ }^{19}$. Najwięcej, bo około połowy potrąceń i zdarzeń, było z udziałem konnych wozów towarowych oraz roboczych - między innymi piwowarskich czy piekarskich. To na przełomie wieków, gdy liczba ludności wynosiła 3/4 miliona, a miasto ograniczone fortami i Cytadelą okazało się zbyt ciasne, natężenie ruchu i liczba wypadków osiągnęły apogeum ${ }^{20}$.

\section{Oznaki „wielkiego oddzielenia”}

Koniec lat 90. XIX wieku oznaczał wyhamowanie wzrostu liczby zwierząt pociągowych w Warszawie, podczas gdy liczba ludności wciąż rosła, co wiązało się z „pierwszą falą emigracji koni poza granice miasta"21. W lutym 1905 roku miasto podpisało umowę z konsorcjum Zarządu Tramwajów Miejskich na przebudowę sieci trakcji konnej na elektryczną. W miarę postępów prac pozbywano się zatem koni z miasta ${ }^{22}$.

Stopniowa elektryfikacja zapowiadała pogorszenie warunków życia tych zwierząt i stosunku do nich ludzi. Pisał o tym w 1906 roku na łamach pisma „Jeździec i Myśliwy” jego redaktor i hipolog Stanisław Wotowski:

Patrząc na konie, ciągnące obecnie warszawskie tramwaje, nasuwa się pytanie, czy jest dozwolonem, godziwem wyczerpywać zwierzęta, wyniszczać je całkowicie. Odpowiedź zdaje się zbyteczna. [...] tylko w imię ludzkości, litości dla zwierząt, a również w interesie samego zarządu tramwajów zwracamy uwagę na nędzny wygląd koni i niewłaściwe, nieumiejętne obchodzenie się z nimi. Jeżdżąc często tramwajami zauważyłem dużo koni wychudzonych, obdartych i dużo ponarowionych. Gdy się koń narowi, okładany jest batami i biją go zbiorowo furmani - szczególnie na stacyach - gdzie popadnie, nie szczędząc łbów ${ }^{23}$.

Chcąc skłonić woźniców do zaprzestania przemocy wobec zwierząt, hipolog wysuwał argumenty natury ekonomicznej - być może obawa przed tym, by „cena towaru nie spadła do minimum”, skłoniłaby zarząd do podjęcia właściwych działań. Ponieważ przemówienie do wrażliwości na krzywdę koni wydawało się niemożliwe, potraktowanie ich jako towaru przynoszącego zysk miało stać się pośrednim sposobem na egzekwowanie praw zwierząt. Innym aspektem pojawiającym się w argumentacji była natomiast szkodliwość eksponowania cierpienia zwierząt i narażania ludzi na tego typu obrazy. Jak czytamy:

Podobny widok jest nadzwyczaj przykry i publiczność nie powinna być nań narażona. Katowanie zwierząt jest zasadniczo wzbronione, przytem na zupełnym wyniszczeniu, zepsuciu koni nie osiągnie się za sztukę wyższej ceny, niż kilkanaście lub kilkadziesiąt rubli. 
Teraz przypuszczać można, iż zarząd walczy niedobitkami i stara się z nich wycisnąć to, co jeszcze jest możliwe. System ten, jak już wyżej zaznaczyłem, jest niewłaściwy i nieetyczny. Obecnie przywykliśmy tak dobrze do różnych okropności, krwawych widoków i opisów, że samo poczucie litości przytępione zostało. Byłoby jednak bardzo niemiłym dla zarządu tramwajów faktem, gdyby Towarzystwo opieki nad zwierzętami musiało interweniować i gdyby sprawa koni tramwajowych weszła na porządek dzienny ${ }^{24}$.

Przytoczone słowa Wotowskiego korespondują zarówno z rozpoznaniami Dorothee Brantz, jak i Petera Soppelsy. Historyczka analizowała między innymi proces formowania się rzeźni miejskich w Paryżu i Chicago oraz przemiany, jakie zaszły w postrzeganiu cierpienia zwierząt i ich zabijania. Wskazywała przy tym na ważną kwestię - praktyki rzeźnicze w XVIII i XIX wieku były traktowane jako nieetyczne, ale przede wszystkim ze względu na potencjał demoralizacji osób je obserwujących, dlatego też starano się chronić opinię publiczną przed przykrymi widokami. Przyczyniło się to do modernizacji przemysłu mięsnego w XIX wieku - do likwidacji mniejszych czy pokątnych szlachtuzów oraz przejęcia kontroli nad ubojem przez władze miejskie odpowiedzialne za racjonalne zarządzanie, centralizację i tworzenie odizolowanych od spojrzeń ludzi rzeźni na obrzeżach miasta ${ }^{25}$. Z kolei według Soppelsy XIX wiek łączył się z rozwojem idei praw zwierząt powiązanych z silną motywacją antropocentryczną - troska o konie pracujące mogła wynikać z obawy o to, że przedstawiały one wartość użytkową, dlatego przeciążanie ich i nadmierna eksploatacja nie przynosiły korzyści człowiekowi. Niemniej jednak ze względu na gwałtowną intensyfikację ruchu ulicznego oraz przeludnienie, przyczyniające się do wzrostu nadużyć wobec koni w miastach, zaczęto w większym stopniu przejmować się ich kondycją i sposobami traktowania przez ludzi ${ }^{26}$.

Niewątpliwie dbaniu o dobrostan zwierząt sprzyjało zastąpienie koni technologią i wprowadzenie tramwajów elektrycznych. Te pojawiły się na ulicach Warszawy 26 marca 1908 roku. Pierwsza linia przebiegała przez plac Krasińskich, ulicę Miodową, Krakowskie Przedmieście, Królewską, Marszałkowską i rogatki mokotowskie. Wraz z elektryfikacją transportu liczba koni w mieście znacznie spadła. Ostatnia licytacja 100 koni tramwajowych odbyła się w 1909 roku w zajezdni przy ulicy Wolskiej. Mimo to tramwaje konne jeździły jeszcze przez kilka lat na trasie „Młynarska-Wieś Wola”27. Ponadto w połowie lat 20. XX wieku zauważalny był wyraźny wzrost znaczenia transportu samochodowego. W Warszawie znajdowało się wówczas 7800 koni, czyli niemalże o połowę mniej w porównaniu ze stanem z przełomu XIX i XX wieku²8.

Zwierzęta te nie zniknęły jednak z miasta - przez całe dwudziestolecie międzywojenne nadal pozostawały obecne w ruchu osobowym. Pracowały zaprzęgnięte do różnego rodzaju wozów i platform, chociaż stopniowo wypychane były ze śródmiejskiej części Warszawy. W obrazie ulicy stykały się w tym okresie tramwaje elektryczne, samochody, dorożki, wozy, rowery, a także zarówno wodopoje dla koni, jak i pierwsze dystrybutory paliw. Pozwala to uchwycić moment przejścia - było to bowiem zjawisko o zmiennej dynamice, zależne od sytuacji gospodarczej i społecznej.

W „Kurierze Warszawskim” jeszcze z 1937 roku z dezaprobatą odnotowywano eklektyzm w transporcie, co nie przystawało do wizerunku miasta europejskiego:

[...] chyba żadne miasto europejskie (w prawdziwym tego słowa znaczeniu) nie posiada tak różnorodnego taboru wehikułów komunikacyjnych jak Warszawa [...]. W takich na przykład Alejach Jerozolimskich, głównej i bodajże najszerszej arterii społecznej, spotykamy wytworne limuzyny i chłopskie wozy, dorożki konne i tramwaje elektryczne, olbrzymie autobusy P.K.P. i „platformy” zaprzęgnięte w chabety, taksówki i wózki ręczne, wozy ogumione i zwykłe fury z węglem lub cegłą, szybkobieżne motocykle i staroświeckie trycykle rowerowe, rowery, hulajnogi(!), konie luzem, a nawet... stada krów²9.

Jednak w całej tej enumeracji, jak przekonuje Milewski, dominowały i najbardziej zwracały uwagę pojazdy konne. Uchodziły za sprawiające problemy, między innymi „ślizgały się na gładkich jezdniach" i powodowały najwięcej wypadków, dlatego władze miejskie próbowały 
ograniczyć ich ruch w „pryncypialnych” ulicach, co wówczas nie przynosiło jednak rezultatów:

Szlachetne rumaki będą po dawnemu ozdobą śródmieścia, nawet wówczas, gdy przez Aleję Jerozolimską ciągną naładowaną betami i gratami furkę, wóz siana czy platformę zardzewiałego żeliwa. Inny człowiek złośliwy twierdził, że z tej obiektywności ojców miasta śmieją się... same konie ${ }^{30}$.

O tym, że rugowanie koni, ale także zwierząt hodowalnych poza granice miasta było procesem długotrwałym, świadczy chociażby zarządzenie z „Kroniki Warszawy” z 1936 roku, dotyczące Zakazu utrzymywania bydła rogatego i nierogacizny w mieście:

[...] Warsz. Dz. Wojewódzki nr 11 ogłasza zarządzenia starostów grodzkich, zakazujące ze względów zdrowotnych utrzymywania bydła rogatego i nierogacizny na terenie komisariatów śródmiejskich i częściowo przedmiejskich. Istniejące krowiarnie i chlewy mają być zlikwidowane na terenie starostwa Śródmiejsko-Warszawskiego na ogół do 31 grudnia 1936 r., na terenie zaś innych starostw - do 31 maja 1937 r. (częściowo do 31 grudnia 1936 r.). Zarządzenia weszły w życie z dn. 5 sierpnia $1936 \mathrm{r}^{31}$

Występowało ono z takimi ogłoszeniami jak Obowiq̨zek maleinizacji zwierzq̨t jednokopytowych - badania służącego diagnostyce nosacizny, głównie u koni - czy Kursy dla oglądaczy mięsa organizowane przez rzeźnię miejską w Warszawie, uczące, jak przeciwdziałać zakaźnym chorobom zwierzęcym i wykrywać obecność włośni. Wiązały się one wyraźnie z rozwojem wiedzy z zakresu bakteriologii ${ }^{32}$.

Wyjaśnienie, że konie usuwano stopniowo z miast, ponieważ zastępowały je tramwaje elektryczne, jest słuszne, ale niewystarczające. Za Soppelsą można powiedzieć, że przyczyniły się do tego nie tylko usprawnienia w transporcie, lecz także wspomniany wcześniej rozwój ruchów na rzecz praw zwierząt oraz wzrost wiedzy z zakresu higieny nakazującej walkę z miejskimi nieczystościami, niechcianymi zapachami i chorobami zakaźnymi - z nimi bowiem zaczęto utożsamiać zwierzęta. Proces ten, który za Atkinsem możemy określić mianem „wielkiego oddzielenia”, pozostaje - mimo odmiennych przebiegów i chronologii zdarzeń - wspólny dla wielu miast europejskich ${ }^{33}$. Podobnie w Warszawie zauważalna stawała się potrzeba pozbycia się z niej zwierząt hodowlanych i koni, kiedy na początku XX wieku zachodziła mechanizacja oraz modernizacja transportu miejskiego połączona ze wzrostem wiedzy bakteriologicznej, higienicznej i weterynaryjnej.

Według Soppelsy konie zapełniały ulice i napędzały infrastrukturę oraz rozwój dziewiętnastowiecznych miast. Nie tylko usprawniały, lecz także wręcz warunkowały ich funkcjonowanie. Początkowo były traktowane jako maszyny i narzędzia, co okazywało się możliwe dzięki instrumentalizacji, u której podstaw leżała dekontekstualizacja - oderwanie zwierząt od swojego otoczenia, na przykład separacja młodych koni od klaczy i osadzenie ich w nowej roli, którą miały do spełnienia w mieście. Na przełomie wieków zachodził natomiast odmienny proces, który historyk nazywa naturalizacją koni, kiedy to zaczęły być sytuowane po stronie tego, co wiejskie, organiczne i tym samym już niechciane w otoczeniu człowieka ${ }^{34}$. Dystansowanie się wobec nich, traktowanie jako czynnik destabilizujący porządek miejski rozwija się także wraz z dyskursami dotyczącymi ochrony zwierząt, w ramach których konie zostają dostrzeżone jako istoty żywe i czujące, już niepasujące do ówczesnego miasta. Z tym wiąże się także proces zmian w podejściu do definicji, prowadzący do uznania koni za zwierzęta pozamiejskie, przejścia od wizji miasta organicznego do miasta mechanicznego z rozwiniętą siecią sanitarną i drogową, w którym nie ma już miejsca dla tego, co uznawane jest za naturalne, a więc koni oraz zwierząt gospodarskich ${ }^{35}$. 


\section{PRZYPISY}

1 Teksty podejmujące metodologiczne i teoretyczne zagadnienia związane z badaniami historii zwierząt: m.in. E. Fudge, A Left-Handed Blow: Writing the History of Animals, w: N. Rothfels (red.), Representing Animals, Bloomington 2002: H. Kean, Challenges for Historians Writing Animal-Human History: What Is Really Enough? "Anthrozoös: A Multidisciplinary Journal of the Interactions of People and Animals" 2012, t. 25.

2 W interesujący sposób na temat różnic dzielących ludność wywodzạca się z trzech zaborów w odrodzonej Polsce pisał Andrzej Chwalba w książce 1919. Pierwszy rok wolności, Wołowiec 2019. O różnicach w kontekście rozwiązań sanitarnych i higieniczych wspomina także Magdalena Gawin w artykule Miasto i higiena, w: M. Kopczyński (red.), Ziemia obiecana. Miasto i nowoczesność, Warszawa 2015.

3 J. Galewski, L.B. Grzeniewski, Warszawa zapamiętana. Ostatnie lata XIX stulecia, Warszawa 1961, s. 21

4 É. Baratay, Zwierzęcy punkt widzenia. Inna wersja historii, przeł. P. Tarasewicz, Gdańsk 2014, s. 112, 127.

5 P. Atkins, Animal Wastes and Nuisances in Nineteenth-Century London, w: tenże (red.), Animal Cities. Beastly Urban Histories, Farnham 2012. Zob. tamże tekst Sabine Barles, Undesirable Nature: Animals, Resources and Urban Nuisance in Nineteenth-Century Paris. Zob. w tym tomie Zwierzęce nieczystości i utrapienia w dziewiętnastowiecznym Londynie w przekładzie Justyny Schollenberger. Z kolei Clay McShane i Joel A. Tarr na przykładzie rozwoju miast w Stanach Zjednoczonych dochodzą do podobnych wniosków co wspomniani badacze. Zob. The Horse in the City. Living Machines in the Nineteenth Century, Baltimore 2007.

6 S. Milewski, Codzienność niegdysiejszej Warszawy, Warszawa 2010, s. 148-149. Cytat z artykułu w: „Wiek" 1880, nr 264. Nazwa ulicy została zmieniona na Aleje Jerozolimskie w pierwszym dziesięcioleciu XX wieku.

7 J.S. Majewski, Warszawa nieodbudowana. Metropolia belle époque, Warszawa 2003, s. 292

8 Zob. rozdział Żywoty proletariuszy z książki: É. Baratay, Zwierzęcy punkt widzenia..., dz. cyt.

9 J. Hribal, "Animals Are Part of the Working Class": A Challenge to Labor History, "Labor History” 2003, t. 44

10 Tamże, s. $435,436$.

11 Ł. Sobechowicz, Konie Warszawy - historia w liczbach, "Almanach Muzealny” 2014, nr 8, s. 106, 108.

12 Tamże, s. 105

13 Tamże, s. 109

14 Tramwaje konne 1866-1908, oprac. H. Polańska, Warszawa 2016, s. 3, 5, 62, 67.

15 Tamże, s. 67, 73

16 Ł. Sobechowicz, Konie Warszawy... dz. cyt., s. 108. Spółka zarzadzająca tramwajami posiadała od końca XIX wieku do 1908 roku i elektryfikacji transportu zbiorowego 750 koni, natomiast straż pożarna do wybuchu I wojny światowej 192, a instytucja miejska dbająca o porządek na ulicach 124 konie.

17 S. Milewski, Życie uliczne niegdysiejszej Warszawy, Warszawa 2013, s. 52-53.

18 Tamże, s. 53. Cytat z artykułu z "Gazety Polskiej" 1874, nr 5.

19 Tamże, s. 55-57. Cytat z artykułu z "Kuriera Warszawskiego” 1882, nr 236. Późniejsze rozporządzenie O ruchu ulicznym m.st. Warszawy zostało wydane przez Komisariat Rządu 15 maja 1925 roku. Było wzorowane na przepisach paryskich z tego samego roku. S. Milewski, Życie uliczne..., dz. cyt., s. 78.

20 Tamże, s. 59, 63

21 Ł. Sobechowicz, Konie Warszawy..., dz. cyt., s. 107.

22 Tramwaje konne 1866-1908, dz. cyt., s. 92.

23 Tamże, s. 93, 95. Cytat z artykułu w: „Jeździec i Myśliwy” 1906, nr 6. Zachowana pisownia oryginalna.

24 Tamże, s. 95

25 Zob. D. Brantz, Recollecting the Slaughterhouse, "Cabinet" 2001, nr 4. W samej zaś Warszawie modernizacja rzeźni na Pradze przy jednoczesnej likwidacji tych mniejszych, przestarzałych i niehigienicznych miała miejsce stosunkowo późno, bo około 1926 roku.

Także Helena Pedersen, szwedzka badaczka, zaznacza, że od XIX wieku zaszły zasadnicze zmiany w „porządku widoczności". Wielka Brytania czy Francja wprowadziły regulacje prawne, przestrzenne i architektoniczne, by odizolowany ubój, w zamkniętej przestrzeni, stawał się niewidoczny dla publiczności. Ograniczenia te szły w parze z późniejszą intensyfikacją uboju. Natomiast pod koniec XIX wieku do nowoczesne wówczas rzeźni w Chicago organizowano wycieczki z przewodnikiem, który pokazywał zwiedzającym linie produkcyjną; mogli oni także obejrzeć rzeź ze specjalnych galerii. Ten rodzaj spektaklu i turystyki stanowi z jednej strony element demonstracji rozwoju, efektywnego, racjonalistycznego zarządzania produkcją, potegi kultury amerykańskiej oraz panowania nad naturą i ciałem zwierzạt, z drugiej zaś wpisywał sie w działalność marketingową służącą zwiększeniu sprzedaży mięsa. Pedersen odnosi się także do rozpoznań Nicole Shukin z książki Animal Capital: Rendering Life in Biopolitical Times, Minneapolis-London 2009. Zob. H. Pedersen, Terror From the Stare: Visual Landscapes of Meat Production, "Antennae. The Journal of Nature in Visual Culture" 2010, nr 14, s. 36. Por. także: G. Baics, M. Thelle, Introdcution: Meat and the Nineteenth-Centruy City, "Urban History” 2018, t. 45, nr 2. 
26 P. Soppelsa, The Instrumentalisation of Horses in Nineteenh-Century Paris, w: R. Boddice (red.), Anthropocentrism. Humans, Animals, Environments, Leiden-Boston 2011, s. 250, 256.

27 Tramwaje konne 1866-1908, dz. cyt., s. 93, 95, 97

28 Ł. Sobechowicz, Konie Warszawy... dz. cyt., s. 107-108. Liczba koni w Warszawie zmniejszyła sie zatem mniej więcej o połowę. Podobne zależności i proporcje dostrzec można na przykładzie Paryża, choć całkowita liczba ludności oraz koni w stolicy Francji była znacznie wyższa. Jak podaje Peter Soppelsa, w 1800 roku w Paryżu znajdowało sie około 15000 koni, w 1900 roku 98000 , a do 1913 roku, kiedy wprowadzono tramwaje elektryczne, ich liczba zmniejszyła się do 55 000. Zob. P. Soppelsa, The Instrumentalisation of Horses..., dz. cyt., s. 246

29 S. Milewski, Życie uliczne..., dz. cyt., s. 79. Cytat z artykułu w: „Kurier Warszawski” 1937, nr 244.

30 Tamże. Cytat z artykułu w: „Kurier Warszawski” 1938, nr 259.

31 "Kronika Warszawy: kwartalnik poświęcony działalności samorządu oraz poszczególnym dziedzinom życia miasta" 1936, r. 12, z. 3, s. 160

32 Tamże. Zob. także K. Kreuder-Sonnen, Mikroby w podróży. Polscy lekarze i niewidoczne organizmy na początku XX wieku, w: R. Makarska (red.), Historie i narracje. Od historii lokalnej do opowieści postantropocentrycznej, Kraków 2019. Geograf Matthew Gandy określa miasta na tym etapie rozwoju mianem bakteriologicznych. Zob. M. Gandy, Bacteriological City and Its Discontents, "Historical Geography” 2006, t. 34

33 P. Atkins, Animal Wastes..., dz. cyt

34 P. Soppelsa, The Instrumentalisation..., dz. cyt., s. 247.

35 Tamże, s. 248 
Justyna Włodarczyk

\section{Parki są dla ludzi? Psy w przestrzeni miejskiej w USA, Wielkiej Brytanii i Polsce}

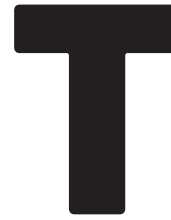

ym, co czyni psa psem, nie jest odrębność genetyczna od wil$\mathrm{ka}$, ale bliska relacja z człowiekiem ${ }^{1}$. Bliskość emocjonalna jest połączona z bliskością fizyczną: pies towarzyszył człowiekowi przez wieki wszędzie tam, gdzie był potrzebny, i wszędzie tam,

gdzie człowiek mu na to pozwolił. W procesach urbanizacji i modernizacji, o których brytyjski geograf Peter Atkins pisze jako o „wielkim oddzieleniu” [great separation] ${ }^{2}$ zwierząt i ludzi, pies pozostawał po wewnętrznej, ludzkiej stronie granicy, której tworzenie Michael Watts, znany amerykański geograf, metaforycznie opisuje jako „wielki akt grodzenia” [gigantic act of enclosure $]^{3}$. Erica Fudge sugeruje z kolei, że otwarcie naszych domów dla zwierząt towarzyszących oznacza zgodę na brak stabilności - zwierzęta domowe z natury przekraczają pewne granice, jakie wyznaczamy, chcąc uzyskać poczucie bezpieczeństwa. Wnosząc brud w nasze ściany, podważają naturalność granicy między tym, co wewnątrz, i tym, co na zewnątrz ${ }^{4}$. Historia regulacji dotyczących trzymania zwierząt w miastach jest więc zapisem różnego rodzaju prób teoretyzowania granic gatunkowych, radzenia sobie ze zwierzęcą innością w zindustrializowanej i cywilizowanej przestrzeni miejskiej. W niedawnych próbach konceptualizacji tych relacji, podejmowanych choćby przez wymienionych wyżej badaczy, uderza metaforyczne wykorzystanie takich terminów jak płot, ogrodzenie, ściana czy nie do końca przetłumaczalne angielskie słowo enclosure, czyli przestrzeń otoczona płotem. W historii relacji ludzie-zwierzęta ogrodzenia metaforyczne przeplatają się z materialnymi - kojcami, zagrodami, klatkami, padokami - a w ostatnich dekadach w miastach wielu krajów zachodnich pojawiły się otoczone płotem części trawników znane jako parki dla psów. Artykuł stanowi próbę refleksji nad kulturowym wymiarem psich parków w USA, Wielkiej Brytanii oraz w Polsce w kontekście szerszych procesów mających związek z regulacjami dotyczącymi przebywania zwierząt towarzyszących w miejskiej przestrzeni wspólnej.

Porównanie rozwiązań z Wielkiej Brytanii i USA jest przedsięwzięciem zasadnym, ponieważ kraje te - choć z pozoru tak podobne kulturowo oraz językowo - charakteryzują się bardzo różnymi regulacjami prawnymi i zwyczajowymi związanymi z kontrolą przebywania psów w przestrzeni miejskiej. Mają one nie tylko swoje uwarunkowania historyczno-geograficzne, które zostaną omówione w tym artykule, lecz także bardzo istotny wymiar społeczno-kulturowy. Rozwiązania brytyjskie sprzyjają tworzeniu przestrzeni wspólnej [the commons], która jednocześnie jest przestrzenią wymieszania gatunków. Tymczasem koncepcje amerykańskie 
zdecydowanie bardziej niż brytyjskie zmierzają w stronę tworzenia przestrzeni, która rozdziela gatunki, przy jednoczesnym kształtowaniu heterotopicznych enklaw międzygatunkowej integracji wyselekcjonowanych psów i ich właścicieli. Czynniki historyczno-geograficzne są, rzecz jasna, nieodłączne od tych procesów i choć warto zachować daleko idącą ostrożność, przeprowadzając analogię między światem ludzkim a pozaludzkim, to jednak nie jest zupełnie nieuzasadnione stwierdzenie - które zresztą postaram się obronić w tym artykule - że parki dla psów w USA stanowią krzywe zwierciadło odbijające momentami w groteskowy sposób napięcia rasowe i klasowe w Stanach Zjednoczonych. Nie są ani gettem (przestrzenią wykluczenia i stygmatyzacji), ani osiedlem strzeżonym [ang. gated community, przestrzenią prestiżu oraz izolacji dobrowolnej], ale ich powstawanie w USA łączy się z napięciami towarzyszącymi procesom modernizacji i gentryfikacji w amerykańskich miastach. Analiza wybranych przypadków - które zostaną omówione w dalszej części artykułu ${ }^{5}$ - pokazuje, że wbrew deklaracjom entuzjastów parków nie są one również dobrem wspólnym [the commons] w rozumieniu przestrzeni współdzielonej i otwartej, podlegającej kolektywnemu, demokratycznemu zarządzaniu ${ }^{6}$.

Proces tworzenia psich parków w USA stanowi odzwierciedlenie zmian w relacjach ludzie-psy. O ile smycz i obroża wywołują skojarzenia z dyscyplinarną kontrolą zachowania, z Foucaultowskim kształtowaniem „podatnych ciał”, o tyle „psie parki” - miejsca, gdzie zwierzęta mogą biegać bez smyczy i bawić się w towarzystwie innych przedstawicieli swojego gatunku - pokazują włączenie niektórych z nich, ulubieńców domowych, w obręb pozytywnych biopolitycznych technik mających na celu podniesienie jakości życia i jego wydłużenie $^{8}$. Opiekunowie chcą, by ich zwierzęta były szczęśliwe, a psi park staje się jedną z technologii mających to szczęście zapewnić. Już samo zidentyfikowanie ruchu nieskrępowanego uwię-

W jakq wizję organizacji przestrzeni miejskiej wpisują się wybiegi dla psów? Kim sa przeciwnicy i zwolennicy parków? Czy skład tej grupy różni się w zależności od kontekstu lokalnego?

zią oraz kontaktu z innymi przedstawicielami gatunku jako podstawowych potrzeb życiowych jest elementem zmian w postrzeganiu relacji ludzi i psów, o których w ciągu ostatnich lat powstały setki tekstów naukowych, ale które można w dużym skrócie podsumować jako ogromne zwiększenie rangi więzi człowieka ze zwierzęciem domowym, włączenie zwierząt towarzyszących w struktury więzi rodzinnych. Jak pisze o kontekście polskim Krzysztof Konecki, wielu Polaków traktuje psa jak członka rodziny ${ }^{9}$. Parki są w tym scenariuszu postrzegane przez właścicieli nieco jako odpowiedniki dziecięcych placów zabaw.

Choć powstawanie parków niewątpliwie wpisuje się w jakościowe zmiany w relacjach zwierząt towarzyszących i ich opiekunów, zamknięcie analizy fenomenu psich parków konstatacją, że chęć ich tworzenia stanowi wyraz miłości opiekunów do swoich ulubieńców, jest nieco naiwne i ignoruje szerszy kontekst społeczny tego procesu. Zdefiniowanie konieczności zaspokojenia potrzeb psa obrazuje bowiem pewien kapitał symboliczny, który nie jest współdzielony przez wszystkich mieszkańców miast, stąd zasadna wydaje się analiza historii powstawania parków i napięć im towarzyszących. W jaką wizję organizacji przestrzeni miejskiej wpisują się wybiegi dla psów? Kim są przeciwnicy i zwolennicy parków? Czy skład tej grupy różni się w zależności od kontekstu lokalnego? Choć artykuł ten ma charakter przeglądowo-teoretyczny, a jego podstawową metodologią jest analiza opublikowanych studiów przypadku oraz materiałów z prasy popularnej, jest on również wynikiem obserwacji uczestniczącej, jaką autorka (wraz z towarzyszącymi jej psami) przeprowadziła w kilkunastu parkach warszawskich w 2018 roku oraz w kilku parkach amerykańskich, w większości w stanie Illinois, w roku $2017^{10}$.

Analiza genezy oraz roli parków dla psów w krajach innych niż Polska jest zadaniem o tyle istotnym, że w ciągu ostatnich kilku lat ta forma organizacji przestrzeni na dobre 
zadomawia sięw polskim krajobrazie miejskim. Choć pierwszy polski park dla psów, otwartyw Łodzi w2005 roku, nie przetrwał dłużej niż kilka dni(został zdewastowany) ${ }^{11}$, przezostatnie paręlata zwłaszcza odkąd miasta i gminy zaczęły wprowadzać budżety partycypacyjne (znane również jako budżety obywatelskie), czyli od 2011 roku - tworzenie wygrodzonych przestrzeni zabaw dla psów i ich właścicieli nabrało rozpędu. W samej Warszawie pod koniec roku 2019 działało - lub było w budowie - nie mniej niż 25 wygrodzonych wybiegów dla psów ${ }^{12}$. Mimo ewidentnych inspiracji amerykańskimi parkami polskie wybiegi mają swoją specyfikę, która dotyczy zarówno organizacji przestrzeni, charakteru interakcji między jej użytkownikami, jak i funkcji parków w dyskursie publicznym. Ich tworzeniu nie towarzyszą tak silne napięcia społeczne jak w USA, co nie znaczy, że konflikty wokół nich zupełnie nie istnieją. W kontekście polskim parki zdają się propozycją, która rozładowuje napięcia związane z koegzystencją psów i ludzi w mieście: ich zwolennicy roztaczają idylliczne wizje harmonijnego współistnienia ludzi i nie-ludzi, oddzielonych płotami, które dzielą przestrzeń w jasny sposób tak, by każdy mógł być szczęśliwy na przynależnej mu ogrodzonej części trawnika. Mimo to nawet pobieżna analiza polskich narracji dotyczących psich parków ujawnia rysy na tym sielankowym obrazie.

\section{Psie parki w USA}

Pierwszy psi park, czyli wygrodzony metrowej wysokości siatką trawnik przeznaczony do psich zabaw i zaopatrzony w kilka ławeczek oraz stolików dla właścicieli, powstał w 1979 roku w Berkeley, w Kalifornii ${ }^{13}$. Współczesne amerykańskie parki nie różnią się znacząco wyglądem od tego pierwszego, który zresztą istnieje do tej pory. Choć parki miejskie są zdecydowanie mniejsze od podmiejskich, nieodzownym elementem każdego wybiegu jest ogrodzenie, zwykle o wysokości od czterech do sześciu stóp ${ }^{14}$. Wiele amerykańskich parków zawiera elementy małej architektury dla właścicieli, głównie stoły i ławeczki, a także wszechobecne w USA poidełka z bieżącą wodą (często ulokowane nisko nad ziemią, na wysokości psiego pyska), bramki zaopatrzone w zapewniającą bezpieczeństwo śluzę, oraz - znacznie rzadziej - infrastrukturę dla samych zwierząt, na przykład przeszkody czy sprzęt treningowy.

Nie jest oczywiście bez znaczenia, że pierwszy psi park powstał w Berkeley, zamożnej i jednocześnie politycznie liberalnej miejscowości w postępowym stanie, która w dodatku ze względu na swój uniwersytecki charakter oparła się procesowi suburbanizacji, charakteryzującemu od pierwszych powojennych dekad rozwój miejski w USA. Pod koniec lat 70. XX wieku posiadanie psa było w znacznej mierze symbolicznym atrybutem przynależności do klasy średniej, podobnie jak kupno domu z ogródkiem na przedmieściach. Jednak w miejscach o dużej gęstości zamieszkania, takich jak Berkeley, opiekunowie psów nierzadko nie byli jednocześnie właścicielami ogrodów, a więc często przebywali z nimi w przestrzeni miejskiej. Powstanie parku Ohlone - notabene nazwanego na cześć plemienia rdzennych mieszkańców obecnej Kalifornii wpisywało się w radykalizm polityczny Berkeley, który przejawiał się choćby w słynnych protestach studenckich z 1969 roku. Psi park powstał na terenie przejętym przez aktywistów miejskich. Założono tam najpierw ogólnodostępny park, znany jako People’s Park, gdzie po kilku latach wygrodzono - z inicjatywy grupy opiekunów psów - fragment przeznaczony specjalnie dla tych zwierzą ${ }^{15}$. Inni okoliczni właściciele psów zareagowali na tę inicjatywę bardzo pozytywnie, a wybieg szybko stał się centrum życia towarzyskiego lokalnej społeczności. W roku 1984 powstała organizacja samorządowa Ohlone Dog Park Association, która do tej pory zarządza tą przestrzenią.

Liczba psich parków w USA zaczęła rosnąć w latach 90. XX wieku, a proces ten był skorelowany w czasie ze znacznie bardziej rygorystycznym przestrzeganiem tak zwanych leash laws, czyli nakazów wyprowadzania psów na smyczy ${ }^{16}$. Nie znaczy to, że wcześniej takie nakazy nie istniały. W większych miastach regulacje dotyczące obowiązku prowadzenia psów na smyczy pojawiły się już w drugiej i trzeciej dekadzie wieku XX, przez długi czas pozostawały jednak martwymi przepisami. I tak na przykład w 1944 roku dziennikarz „The New York Times” narzekał na hordy psów biegających luzem po mieście: „Niedawna panika związana z pojawieniem się wścieklizny na pewno wzbudziłaby mniej strachu, gdyby w mieście było mniej psów biegających luzem, co jest przecież łamaniem prawa"17. Przyczyny, dla których dopiero w latach 90. zaczęto 
przestrzegać istniejących od dawna przepisów, są dość złożone; jednym z ważnych czynników było zwrócenie uwagi mediów w latach 80. na falę pogryzień przez psy, zwłaszcza pitbulle ${ }^{18}$. W reakcji na zwiększone poczucie zagrożenia ze strony biegających luzem czworonogów władze lokalne rozpoczęły kampanie mające na celu karanie właścicieli, którzy spuszczali je ze smyczy. W wielu miastach wypracowano wcześniej pewne status quo, nieformalne porozumienie, pozwalające na puszczanie psów swobodnie na konkretnych nieużytkach, tak zwanych psich łączkach $^{19}$. Akcja policji wymierzona w te zwierzęta była więc całkiem łatwa do przeprowadzenia, bo powszechnie znano miejsca, gdzie spotykali się psiarze. We wszystkich relacjach kreślących rozwój wypadków z tego okresu pisze się o ostrym konflikcie, a w opracowaniach pojawiają się takie słowa jak wojna, obława, nagonka [war, hunt, raid, crackdown] ${ }^{20}$. W tym burzliwym okresie niektóre miasta, zwłaszcza małe i średniej wielkości, położone poza głównymi aglomeracjami, wprowadziły całkowity zakaz wstępu z psami do parków miejskich. I tak od końca lat 70. do roku 2017 zwierzęta te nie mogły przebywać w żadnym parku miejskim w Billlings, największym mieście stanu Montana ${ }^{21}$. Zakaz wprowadzania czworonogów do lokalnych parków w Greenfield, dzielnicy Milwaukee w stanie Wisconsin, cofnięto dopiero w 2018 roku. W mieście tym psom dalej nie wolno wchodzić do parków zarządzanych przez sześć z lokalnych dwudziestu ośmiu jednostek administracyjnych (odpowiadających polskim dzielnicom miast) ${ }^{22}$.

W latach 90. mamy więc do czynienia z sytuacją, w której dostępna zwierzętom przestrzeń wspólna [commons] ulega znacznemu okrojeniu. Parki dla psów nie są jednak propozycją władz lokalnych mającą na celu złagodzenie napięć. Wręcz przeciwnie, to właściciele psów, zdając sobie sprawę z przegranej pozycji, rozpoczęli lobbing na rzecz tworzenia wygrodzonych enklaw dla tych zwierząt. To rozwiązanie, choć pozornie zdaje się godzić interesy obu stron, wcale nie zostało pozytywnie przyjęte przez mieszkańców niechętnie nastawionych do czworonogów. W obszernej literaturze dotyczącej psich parków w USA przytoczonych jest mnóstwo konfliktów w obrębie lokalnych społeczności między zwolennikami i przeciwnikami psich parków. Często powstają organizacje wspierające budowę parku, których pierwszym celem jest dążenie do uzyskania pozytywnej opinii w tej sprawie u lokalnych włodarzy ${ }^{23}$. Organizacje te następnie przekształcają się w rady zarządzające parkami, wymagającymi ciągłych inwestycji. Ich przedstawiciele muszą jednak liczyć się z długą i żmudną walką z przeciwnikami takich przestrzeni. Zrozumiałą, choć typowo amerykańską reakcją na ograniczanie przestrzeni dostępnej dla psów przez władze miasta jest zakładanie prywatnych psich parków. Chociaż wiele z parków zakładanych na terenach należących do miasta i tak wymaga uiszczania opłat za możliwość korzystania z wybiegów ${ }^{24}$ (które są przeznaczane na konserwację terenu, wywóz śmieci itp.), to te prywatne działają na zasadach czysto komercyjnych. Od 2016 roku dostępna jest również aplikacja Sniffspot, która pozwala właścicielom nieruchomości na krótkoterminowe wynajmowanie ogródków opiekunom psów, szukającym miejsca, gdzie mogliby legalnie spuścić je ze smyczy. To wszystko sugeruje, że w Stanach Zjednoczonych, kraju z pozoru przyjaznym zwierzętom, niechętnie patrzy się na psy w miejskiej przestrzeni publicznej. Niektórzy badacze odczytują tę niechęć jako wyraz swoistej obsesji czystości. Kulturoznawczyni Karla Armbruster sugeruje wręcz, że „coraz mocniejsza tendencja do ciągłego trzymania psów na smyczy czy w zamknięciu może być odczytana jako część szerszego zainteresowania czystością: próbą wyczyszczenia przestrzeni publicznej przez usunięcie z niej tego, co jest postrzegane jako brudne, brzydkie, niewygodne i niebezpieczne"25.

Ta obsesja czystości ma oczywiście swoją historię, która łączy się z procesami modernizacyjnymi. W książce Animal Cities Peter Atkins pisał o rugowaniu zwierząt z przestrzeni miejskiej jako o elemencie modernizacji nieodłącznie powiązanej ze wzrostem zainteresowania higieną ${ }^{26}$. W tym rozumieniu miasto, przestrzeń nowoczesnych ludzi i maszyn, musiało zostać zdefiniowane w opozycji do wsi, która pozostawała przestrzenią, gdzie to, co ludzkie, mieszało się z tym, co zwierzęce. Atkins pisał co prawda o dziewiętnastowiecznej Anglii i o stopniowym wprowadzaniu zakazu trzymania w miastach zwierząt gospodarskich, ale argumenty przeciwników psów w parkach miast środkowego i północnego zachodu USA są zaskakująco podobne. Te małe prowincjonalne ośrodki miejskie - Billings, choć jest największym miastem Montany, liczy zaledwie 100000 mieszkańców - starają się podkreślić swój miejski status przez pozbycie się zwierząt z przestrzeni wspólnej, wykorzystując takie same argumenty, jakich używano do ograniczenia pogłowia świń i krów w Londynie ponad sto lat wcześniej, czyli odwołując się 
do koncepcji postępu i higieny. W 2018 roku zwolennicy zakazu w Greenfield „mówili, że psy są nieprzewidywalne, a jeszcze bardziej nieprzewidywalni są ich właściciele, którzy prawdopodobnie nie będą po nich sprzątać, pozwolą im biegać luzem i nie dopilnują terminów szczepień"27. Podobne argumenty pojawiają się w akademickich opracowaniach osób przeciwnych parkom dla psów. Julie Urbanik i Mary Morgan, pisząc o konsultacjach z 2006 roku mogących potencjalnie prowadzić do utworzenia drugiego parku dla psów w Kansas City - średniej wielkości mieście w przeważająco rolniczej okolicy - zwracają uwagę na wszechobecność argumentu o zagrożeniu epidemiologicznym stwarzanym przez te zwierzęta oraz uczuciu obrzydzenia wywołanego przez ich bliskość, nawet gdyby odgrodzone one zostały płotem: „Sąsiedzi nie chcą, żeby smród docierał do ich domów". Inne odnotowane przez Urbanik i Morgan komentarze to: „Psie parki są fajne, o ile koło nich nie mieszkasz. Nikt nie chce mieszkać koło wysypiska śmieci, choć każdy chce, żeby miasto je miało”; „Byłbym szczęśliwszy, gdyby ich [psów] nie było. Parki są dla ludzi!"28. Porównanie psiego parku z wysypiskiem śmieci przywołuje klasyczną definicję nieczystości Mary Douglas z Czystości i zmazy - śmieciem jest to, co nie jest na swoim miejscu, a w rozumieniu autorów tych komentarzy w mieście nie na miejscu jest pies ${ }^{29}$.

Amerykańską debatę dotyczącą psich parków i miejsca psów kształtują także typowa dla tego kraju waga własności prywatnej oraz równie typowe przeformułowanie [re-framing] kontrowersyjnego tematu jako należącego wyłącznie do sfery prywatnej. Zasadne wydaje się bowiem zadanie przeciwnikom psów pytania: skoro w przestrzeni miejskiej zwierzęta nie mogą mieszać się z ludźmi, to gdzie w takim razie właściciele mają wyprowadzać swoje psy? Uczestnicy badania Urbanik i Morgan mają na to pytanie jednoznaczną odpowiedź: w ogrodzie właściciela. Jeden z respondentów ankiety napisał: „Jeśli ktoś nie ma przestronnego, ogrodzonego ogrodu dla swojego psa, to nie powinien mieć psa”, i głos ten nie był odosobniony ${ }^{30}$. Przekonanie o nienaruszalności prawa własności, silne w USA, przekłada się na specyficzne, zwłaszcza w obyczajowo konserwatywnych stanach Midwestu, rozumienie podziału na sferę publiczną i prywatną. Sfera prywatna, pozostając poza zasięgiem władz państwowych, może z jednej strony stać się ostoją wartości konserwatywnych, z drugiej zaś także schronieniem dla wszelkich praktyk, które wykraczają poza wąsko rozumiany konsensus społeczny. To rozumienie stwarza mechanizmy spychania w sferę prywatną wszelkich praktyk, które mogą zostać uznane za kontrowersyjne. Choć artykuł ten nie jest miejscem na analizę amerykańskich dyskusji o sferze prywatnej i publicznej, warto zaznaczyć, że mechanizmy te omówiono najszerzej na przykładzie nienormatywnych praktyk seksualnych, na przykład przez Lauren Berlant i Michaela Warnera czy Lisę Duggan ${ }^{31}$. W przytaczanym przez Urbanik i Morgan dyskursie przeciwników psich parków (oraz jednocześnie przeciwników przebywania psów w parkach) samo posiadanie czworonoga nie jest wyborem kontrowersyjnym, o ile nie ma wpływu na kształt sfery publicznej, której częścią jest w tym rozumieniu ogólnodostępna (ludziom) miejska przestrzeń zielona. W argumentach przeciwników psów nie ma miejsca na elastyczność w sferze publicznej wobec interesów osób, których praktyki postrzegane są jako mniejszościowe, a już na pewno nie ma w nich miejsca na rozpoznanie psów jako podmiotów prawa.

Mimo wszystkich trudności związanych z zakładaniem parków (a być może właśnie ze względu na nie) przykład amerykański pokazuje, że ich tworzenie może być działalnością integrującą właścicieli psów i sprzyjającą budowaniu poczucia wspólnoty lokalnej. Co więcej, zawiązane w ten sposób społeczności, jak pokazuje przykład Ohlone Dog Park Association, potrafią przekuć zryw założycielski w działalność długoterminową. Warto jednak zwrócić uwagę na jeszcze jeden wątek z obszernej w tej chwili literatury naukowej dotyczącej amerykańskich parków dla psów: powiązania kwestii ich budowy z procesami gentryfikacji, zmiany struktury społeczności lokalnej przez napływ nowych, zamożniejszych mieszkańców. Lokalizacje amerykańskich psich parków można podzielić na dwa podtypy: parki budowane na przedmieściach czy w miastach o mało zwartej zabudowie oraz parki powstające w zwartej zabudowie miejskiej, często w dzielnicach, gdzie wprowadzają się nowi mieszkańcy, nieraz byli mieszkańcy przedmieść, którzy świadomie decydują się przenieść (często: przenieść z powrotem) do miasta. W pierwszym przypadku do konfliktów dotyczących parków dochodzi w znacznej mierze w obrębie tej samej klasy społecznej (i zwykle rasy), a przeciwników można podsumować jako zwolenników postawy „nie w moim ogródku”. Sprawa psów i ich wybiegów staje się tutaj ujściem niechęci wobec inności, nie tylko gatunkowej, bo przecież to nie fakt istnienia psów jest wymieniany jako 
argument przeciwko parkom, ale powiązane z tymi zwierzętami zagrożenie sanitarno-epidemiologiczne. Niechęć jest nie tylko sprzeciwem wobec czworonogów, lecz także wyrazem braku zrozumienia dla ludzi, którzy dobrowolnie wchodzą z tymi brudnymi istotami w bliższe relacje. Nie przestrzegając zasad higieny, ci ludzie, choć podobni wyglądem i statusem społecznym innym mieszkańcom dzielnicy, tworzą sytuację, która niesie ze sobą zagrożenie oraz burzy spokój i ciszę przedmieść. Przeciwnicy parków widzą w zwolennikach osoby zacofane, sprzeciwiające się modernizacji. Jak pisze Karla Armbruster, mimo miłości deklarowanej wobec pojedynczych psów w wymiarze społecznym psy „zdają się być niekompatybilne z cywilizowanym życiem”32.

W drugim przypadku tego typu antagonizmy są odbiciem konfliktu klasowego. Choć samo posiadanie psa nie jest koniecznie wyznacznikiem statusu społecznego, w grupie gentryfierów, czyli nowych mieszkańców wcześniej podupadłych dzielnic, można odnotować nadreprezentację opiekunów psów. Typowe dla amerykańskich miast ostatnich dekad procesy przejmowania biednych dzielnic miejskich przez przedstawicieli klasy średniej mają zatem szerszy niż ludzki wymiar: nowi mieszkańcy są często właścicielami zwierząt domowych i kształtują swoje relacje z nimi inaczej niż „autochtoniczne” społeczności tych obszarów. Choć niektórzy ze „starych” mieszkańców również mają psy, inicjatywa stworzenia parku dla tych zwierząt zwykle wychodzi od tych nowo przybyłych. Francuska socjolożka Sylvie Tissot w swojej relacji z obserwacji uczestniczącej w parku dla psów położonym w gentryfikującej się dzielnicy Bostonu, w sąsiedztwie Harvard University, podkreśla wykluczający aspekt stworzenia w okolicy ogrodzonego wybiegu dla psów ${ }^{33}$. Chociaż park jest przez jej rozmówców postrzegany jako miejsce integracji społeczności lokalnej, nie spotyka się w nim cały przekrój mieszkańców, a jedynie ci, którzy przyznają, że interakcje $z$ innymi psami są w nim niezbędne dla dobrostanu ich czworonogów. Zwykle są to nowi mieszkańcy. Co jednak w tym przypadku najistotniejsze, dwa główne zagrożenia wymieniane przez rozmówców Tissot, czyli użytkowników wy-

Można spekulować, że te dwa diametralnie różne podejścia do tematu psów w przestrzeni miejskiej w dwóch krajach posługujaccych się tym samym językiem mają związek z różnicami w stosunku do przestrzeni wspólnej, roli zwierzq̨t w tejże oraz w historycznych uwarunkowaniach rozwiq̨zań urbanistycznych stosowanych w miastach brytyjskich i amerykańskich. biegu dla psów, to bezdomni, którzy okupują ławki, oraz zalegające na ulicach śmieci ${ }^{34}$. W tym kontekście, i w przeciwieństwie do wybiegów podmiejskich, park staje się oazą porządku i cywilizacji w miejskiej dżungli. Choć formalnie ten akurat park jest przestrzenią ogólnodostępną (nie wymagana jest tam opłata członkowska), powinien być wykorzystywany zgodnie z przeznaczeniem. Bezdomni nie mają więc do niego wstępu, a jeśli wejdą, łatwo ich wyprosić, oficjalnie nie z powodu wzbudzania poczucia zagrożenia wśród reszty użytkowników, ale dlatego, że nie mają psa ${ }^{35}$. Tissot nie kwestionuje tego, że wśród bywalców parku tworzą się więzi społeczne oraz swoista lokalna tożsamość. Jest to jednak tożsamość oparta na wykluczeniu, na tworzeniu „bezpiecznej” przestrzeni, do której „inni” nie mają wstępu. Jak pisze Tissot, „bariery przestrzenne pozwalają [...] na odgrodzenie się od biednych, przedstawicieli mniejszości etnicznych oraz nienormatywnych populacji”" W6. W kontekście amerykańskich miast dodatkowym czynnikiem jest jeszcze wątek rasowy: dzielnice podlegające gentryfikacji to często rejony zamieszkiwane przez Afroamerykanów i Latynosów, a wprowadzającymi się właścicielami psów są biali. Jak pisze Heidi Nast w artykule dotyczącym psich parków w Chicago, zawartym w książce Landscape and Race in the 
United States (Krajobraz i rasa w Stanach Zjednoczonych): „Biorąc pod uwagę rasowy wymiar bogactwa w USA, nie zaskakuje, że publiczne i komercyjne obszary przeznaczone dla psów są zlokalizowane w elitarnych, białych okolicach" ${ }^{37}$. Nast wylicza, że większość wybiegów dla psów w opisywanej przez nią metropolii jest zlokalizowana w jej północnej części, zamieszkanej przez białych. W dodatku kiedy tylko zdominowane przez mniejszości etniczne dzielnice zaczynają podlegać gentryfikacji, zawiązują się w nich stowarzyszenia, których celem jest stworzenie parku dla psów. Doskonały przykład stanowi sytuacja z dzielnicy Filadelfii, Point Breeze, gdzie jednym z symptomów gentryfikacji był ogromny wzrost liczby pozwoleń na posiadanie psa oraz nacisk nowo przybyłych na utworzenie ogrodzonego parku dla tych zwierząt. W artykule z prasy lokalnej dotyczącym sytuacji w dzielnicy Afroamerykanin i wieloletni mieszkaniec Point Breeze komentował swoją niechęć wobec parku: „Ludzie mieszkają tu od stu lat, jest tu plac zabaw dla dzieci, a teraz [nowi - J.W.] ludzie sprowadzają się i chcą wszystko zmienić. [...] Dobrze, wyprowadzajcie te swoje psy, ale nie myślcie, że tak może być, że ludzie się sprowadzają i po prostu wszystko przejmują" ${ }^{38}$. Niechęć wobec budowy wybiegu jest powiązana z awersją wobec zmian ekonomicznych i społecznych zachodzących w okolicy oraz z poczuciem zagrożenia tożsamości rasowej danej okolicy ${ }^{39}$.

\section{Psy i parki miejskie w Wielkiej Brytanii}

W Wielkiej Brytanii nie przyjęły się rozwiązania amerykańskie, czyli tworzenie wygrodzonych enklaw dla psów przy jednoczesnym ograniczaniu możliwości przebywania ich bez smyczy (a czasem nawet na smyczy) w parkach miejskich. Amerykańskim opiekunom psów Wielka Brytania, a czasem cała Europa, jawi się jako kraina wolności, w której zwierzęta te mogą swobodnie biegać w miejscach, do których amerykańskie czworonogi nie miałyby wstę$\mathrm{pu}^{40}$. Nie znaczy to, że w Wielkiej Brytanii nie istnieją wygrodzone, zamknięte wybiegi dla psów, ale nie stają się one ośrodkami mobilizującymi społeczność właścicieli zwierząt; nie są centrum życia towarzyskiego psio-ludzkiej społeczności. Powstawaniu wybiegów, finansowanych zwykle przez lokalne władze samorządowe, nie towarzyszą również tak wielkie napięcia jak w USA. Co więcej, w przeciwieństwie do USA ich zakładanie nie jest postrzegane przez środowisko właścicieli psów jako zjawisko pozytywne. Wręcz przeciwnie, zwykle ich tworzenie jest odbierane przez mieszkańców miast jako powiązane z ograniczaniem możliwości przebywania z psami w miejscach publicznych. Ma to bowiem związek z historią prawnych regulacji przebywania tych zwierząt w przestrzeni miejskiej w Wielkiej Brytanii.

I tak w pierwszych latach XX wieku - czyli w okresie, kiedy trzymanie w domach oraz hodowla psów rasowych stały się popularnym hobby miejskiej klasy średniej ${ }^{41}-\mathrm{w}$ większych miastach Anglii zaczęły pojawiać się przepisy dotyczące konieczności prowadzenia ich na smyczy po publicznych drogach pieszych [along public footpaths]. Jak pisze Philip Howell w książce At Home and Astray, prawa te powoli zastępowały kompletnie nieprzestrzegane zapisy wymuszające nakładanie psom kagańców, które to regulacje z kolei uchwalano w związku z obawami przed rozprzestrzenianiem przez biegające czworonogi wścieklizny. Howell, odwołując się do koncepcji rządomyślności Foucaulta, przypuszcza, że przyjęcie praw związanych z wyprowadzaniem ich na smyczy mogło oznaczać istotną zmianę w postrzeganiu relacji psa i jego właściciela ${ }^{42}$. Odpowiedzialność właściciela w starym systemie, w którym pies w kagańcu jest wypuszczony luzem, aby się wybiegał, kończyła się na założeniu zwierzęciu kagańca. Jak pisze Howell, wprowadzenie przepisów obligujących właścicieli do wyprowadzania psów na smyczy rozciąga odpowiedzialność właściciela, jednocześnie tworząc sytuację, w której pies i człowiek, połączeni smyczą, stają się razem podmiotem prawa ${ }^{43}$. Jak sugeruje Howell, nie do końca incydentalnym skutkiem ubocznym wymogu wyprowadzania psów na smyczy jest wzmocnienie więzi między człowiekiem a zabranym na spacer zwierzęciem - bo przecież pies fizycznie przywiązany do człowieka wymaga więcej jego uwagi, więcej interakcji niż wypuszczony na dwór luzem. Przychylność dla takich rozwiązań dodatkowo wzrosła, kiedy po roku 1902 wyeliminowano wściekliznę ze Zjednoczonego Królestwa, a psy przestały budzić strach jako potencjalne źródło zagrożenia śmiertelną chorobą, o czym piszą Michael Warboys i Neil Pemberton w książce Mad Dogs and Englishmen ${ }^{44}$. Jednocześnie prowadzenie psów 
na smyczy po publicznych drogach pieszych nie wiązało się z zakazem ich wstępu do parków miejskich, które zwyczajowo traktowano jako miejsce, gdzie mogły biegać luzem, o ile pozostawały pod kontrolą właściciela. Około połowy XX wieku swoistym standardem dla właściciela psa, przedstawiciela miejskiej klasy średniej, stało się prowadzenie go do parku i spuszczanie tam ze smyczy. Co więcej, w drugiej połowie XX wieku Wielka Brytania pozostawała w dalszym ciągu otwarta na psy bez smyczy również na terenach niemiejskich (w tym w parkach narodowych), o ile nie niepokoiły one zwierząt gospodarskich ${ }^{45}$. W Wielkiej Brytanii nie pojawiły się także typowe dla Stanów Zjednoczonych zakazy przewożenia zwierząt domowych komunikacją publiczną.

Nie znaczy to oczywiście, że relacje między właścicielami psów a pozostałymi mieszkańcami miast były w Anglii zawsze harmonijne; niemniej nigdy nie doszło tam do tak masowego wprowadzenia wymogów prowadzenia tych zwierząt na smyczy oraz tak rygorystycznych zapisów jak w USA. Nieliczne próby całkowitego zakazania przebywania psów w parkach miejskich spotkały się z silnymi protestami mieszkańców i - w efekcie - były bardzo krótkotrwałe. Najdokładniej opisany konflikt związany z próbą wprowadzenia zakazu wstępu psów do parku miejskiego wydarzył się w podupadłym, postindustrialnym Burnley w latach 70. XX wieku (zakaz wprowadzono w roku 1977), w okresie kiedy miasto borykało się z dużym kryzysem ekonomicznym. Konflikt w tym mieście - opisywany przez Neila Pembertona jako „psia wojna w Burnley”miał związek z postrzeganiem psich odchodów pozostawianych w parku jako zagrożenia epidemiologicznego. Według tego autora zbieżność w czasie sporu dotyczącego psich odchodów oraz przebywania psów we wspólnej przestrzeni miejskiej i ekonomiczego upadku miasta sugeruje, że konflikt o miejsce zwierząt w przestrzeni publicznej mógł stanowić ujście napięć związanych z pauperyzacją Burnley oraz starcie dwóch przeciwstawnych wizji: „prawa do posiadania i wyprowadzania psów” oraz „prawa do zachowania czystości i atrakcyjności terenów parkowych”" zwłaszcza w kontekście ogólnej degradacji walorów estetycznych miasta. Warto dodać, że w latach 70. ani w Burnley, ani nigdzie indziej w Anglii nie obowiązywał nakaz sprzątania psich odchodów. Obowiązek taki, przestrzegany zresztą w znacznie mniejszym stopniu niż w USA, został wprowadzony tam dopiero w latach $90 .{ }^{47}$.

Przypadek Burnley był jednostkowy, a miasto zyskało nieoficjalne miano „najmniej przyjaznego psom miejsca w Anglii”48. Konflikt ten stanowi zresztą ciekawy przykład potencjału aktywizmu obywatelskiego środowiska miłośników psów [dog fancy] w Anglii. Ich właściciele dokonywali w parkach miejskich w Burnley aktów nieposłuszeństwa obywatelskiego, które skutkowały nawet aresztowaniami. Mavis Thornton - matka sześciorga dzieci i nauczycielka chemii - stała się wręcz swoistą męczennicą sprawy. W geście obywatelskiego nieposłuszeństwa łamała prawo, spacerując po miejskim parku z psami, za co została aresztowana i osadzona w więzieniu, skąd komunikowała się ze środowiskiem psiarzy z Burnley listownie. Pisała między innymi: „[Więzienie] to upokarzające doświadczenie, które nie daje mi żadnej satysfakcji, ale kieruję swoje myśli w stronę ludzi z Burnley"49. Mavis Thornton zwolniono z więzienia po trzech miesiącach, a zakaz wprowadzania psów do większości parków miejskich cofnięto ${ }^{50}$. Możliwość wprowadzania czworonogów do parków, również bez smyczy, oraz pełnego korzystania z przestrzeni miejskiej pozostaje cechą wyróżniającą Wielką Brytanię po dziś dzień.

Można spekulować, że te dwa diametralnie różne podejścia do tematu psów w przestrzeni miejskiej w dwóch krajach posługujących się tym samym językiem mają związek $\mathrm{z}$ różnicami w stosunku do przestrzeni wspólnej, roli zwierząt w tejże oraz w historycznych uwarunkowaniach rozwiązań urbanistycznych stosowanych w miastach brytyjskich i amerykańskich. I tak Wielką Brytanię charakteryzuje długa tradycja przestrzeni wspólnej - znanej jako the commons. Wiejska przestrzeń wspólna wykorzystywana była przede wszystkim do wypasu zwierząt gospodarskich należących do chłopów [commoners] z danej wsi. Chociaż dostępność tego dobra od XVI wieku była w Anglii regularnie ograniczana tak zwanymi grodzeniami [fencings], w pamięci zbiorowej zachowana została pewna spuścizna przestrzeni wspólnej, skutkująca wyraźnie innym od amerykańskiego rozumieniem własności prywatnej ${ }^{51}$. Można wręcz powiedzieć, że po grodzeniach pastwisk koncepcja commons została przekształcona w sposób, który sprawił, że stosuje się ją z jednej strony w dyskursie ekologicznym (gdzie commons to zasoby przyrodnicze, od których zależy dobro populacji), 
a z drugiej w konceptualizacji przestrzeni miejskich, takich jak parki, błonia, a także transportu publicznego czy dostępu do zasobów wodnych. Coraz częściej można spotkać się z terminem urban commons, czyli miejskiej przestrzeni wspólnej, natomiast w debacie o niej nieśmiało zaczynają pojawiać się również kwestie związane ze zwierzętami ${ }^{52}$. Nie jest więc przypadkiem, że Jonathan Metzger w artykule mającym zwrócić uwagę na włączanie interesów zwierząt w planowanie przestrzeni miejskiej posługuje się siedemnastowiecznym wierszykiem (przytaczanym zresztą wcześniej przez Petera Marcuse’a) ${ }^{53}$ o grodzeniach w Anglii, w którym wyartykułowane jest prawo zwierzęcia (konkretnie gęsi) do przebywania w przestrzeni wspólnej [commons] ${ }^{54}$. Prawo do niej, od momentu pojawienia się tego sformułowania w Anglii, miało związek z wyprowadzaniem zwierząt. Nic więc dziwnego, że wykluczenie psów z parków miejskich spotkało się z tak stanowczym oporem.

Jak wspomniano wcześniej, w ostatnich latach w brytyjskich miastach coraz częściej pojawiają się ogrodzone wybiegi dla psów, które jednak - w przeciwieństwie do tych w USA - nie są postrzegane przez właścicieli czworonogów jako zjawisko pozytywne. Tworzenie parków nabrało rozpędu po roku 2013, kiedy w Wielkiej Brytanii zaczęło obowiązywać rozporządzenie dotyczące ochrony przestrzeni publicznej [Public Space Protection Order]. Przepis ten z założenia miał ułatwić walkę z żebractwem i alkoholizmem, ale zaczął również być wykorzystywany do zwiększenia liczby miejsc niedostępnych psom. Proces tworzenia parków w Wielkiej Brytanii nie doczekał się jeszcze dogłębnych opracowań akademickich, ale debata w mediach doskonale oddaje klimat tego konfliktu, w którym praktycznie wszyscy sympatycy psów oraz organizacje zrzeszające właścicieli wypowiadają się o wybiegach negatywnie. I tak „The Telegraph” w artykule napisanym przez dziennikarza-weterynarza narzeka, że „psy są spychane do gett, pozbawiane możliwości swobodnego biegania poza wyznaczonymi do tego celu małymi, przepełnionymi i źle zarządzanymi parkami dla psów”55. Oświadczenia w sprawie dostępu tych zwierząt do parków wydały już Kennel Club oraz główne organizacje zajmujące się ich dobrostanem, na przykład stowarzyszenie Dogs Trust, które pisze: „Wierzymy, że wszystkie psy powinny mieć sprawiedliwy dostęp [fair access] do miejsc publicznych i szerokie możliwości ruchu na smyczy i bez smyczy" ${ }^{56}$. Z kolei Kennel Club, odpowiednik Związku Kynologicznego w Polsce, w oficjalnym oświadczeniu następująco tłumaczy swoje stanowisko:

Psie parki można zwykle spotkać w krajach takich jak Ameryka, gdzie zasada „psy na smyczy” jest uznawana za domyślną i psy wolno spuszczać wyłącznie w miejscach do tego wyznaczonych. W Wielkiej Brytanii obowiązuje przeciwna zasada, dlatego Kennel Club występuje przeciwko koncepcji psich parków, które zwykle są miejscami bardzo małymi oraz symptomem znacznych ograniczeń nakładanych na psy. [...] Kennel Club sądzi, że parki nie niosą korzyści dla psów, ich właścicieli ani dla szerszej społeczności ${ }^{57}$.

W Wielkiej Brytanii niezwykle ciekawe jest wyartykułowanie prawa psów do swobodnego ruchu w przestrzeni wspólnej; ograniczenia są postrzegane jako dotykające bezpośrednio te zwierzęta, a nie właścicieli, którzy w związku z restrykcjami nie mogą dowolnie dysponować swoją własnością, czyli psem. Pisząc o psach w przestrzeni publicznej w USA, Karla Armbruster zauważa, że mogą one liczyć na wstęp do przestrzeni publicznej wyłącznie jako „akcesoria ludzi, a nawet wtedy zasady dostępu są ściśle kontrolowane”58. W materiałach amerykańskich organizacje zrzeszające sympatyków psów mówią co najwyżej o prawach właścicieli psów do przebywania w przestrzeni parku: prawo psa do korzystania z parku nie pojawia się w ogóle. Peter Marcuse, pisząc o prawie gęsi do przebywania w przestrzeni wspólnej, używał tych ptaków wyłącznie metonimicznie: chodziło mu o ich właściciela, prostego człowieka [commoner], którego prawo do zaspokojenia podstawowych potrzeb życiowych (czyli głodu przez zjedzenie gęsi) jest ograniczane w społeczeństwie kapitalistycznym nastawionym na zwiększanie zysków bogatszych warstw społecznych ${ }^{59}$. Debata dotycząca parków dla psów pokazuje, że obecnie Brytyjczycy traktują prawo gęsi do dobra wspólnego bardziej dosłownie, co widać choćby w dyskusjach o miejscu zwierząt w miejskiej przestrzeni wspólnej [urban commons]. 


\section{Polskie psie parki}

W drugiej dekadzie XXI wieku Polska zdaje się przyjmować psie parki z naiwnym entuzjazmem, który prezentowano na początku lat 90. wobec wszystkiego, co amerykańskie. Jednocześnie parki te trafiają w kontekst, który jest specyficznie polski. Z jednej strony obecność psów na miejskich terenach zielonych, a zwłaszcza nierozwiązany do tej pory problem psich odchodów powodują od kilku dekad napięcia, regularnie przeradzające się w otwarte konflikty ${ }^{60}$. Z drugiej nigdy nie doszło w Polsce ani do wprowadzenia tak ostrych restrykcji dotyczących przebywania psów w miejscach publicznych, ani do masowej mobilizacji właścicieli w ramach aktów nieposłuszeństwa obywatelskiego: nie było nigdy polskiej Mavis Thornton. Częściowo tłumaczy tę sytuację charakter polskich miast i styl życia ich mieszkańców, na przykład nie do pomyślenia byłby w Polsce całkowity zakaz przewożenia zwierząt komunikacją publiczną, który obowiązuje w większości miast amerykańskich ${ }^{61}$.

Polskie prawo nie jest jednak wyjątkowo postępowe na tle reszty Europy. Można wręcz powiedzieć, że polskim psom wolno mniej niż na przykład psom w Czechach czy na Słowacji. Tatrzański Park Narodowy (TPN) zakazuje przebywania psów (również tych na smyczach) na szlakach, uzasadniając to możliwością płoszenia przez nie dzikich zwierząt. Po stronie słowackiej zakazy nie obowiązują, tak jakby te same dzikie zwierzęta były bardziej płochliwe po polskiej. Przepis, na który powołują się TPN oraz inne polskie parki narodowe, zakazujące wstępu z psami, na przykład Bieszczadzki Park Narodowy, to art. 15.1, pkt 16 ustawy o ochronie przyrody z 16 kwietnia 2004 roku. Zgodnie z tym zapisem „w parkach narodowych oraz rezerwatach przyrody zabrania się wprowadzania psów na obszary objęte ochroną ścisłą i czynną" ${ }^{2}$. Nie istnieje jednak jednoznaczna wykładnia tego przepisu i wielu innym parkom narodowym psy nie przeszkadzają, o ile są na smyczy.

Wspomniany przepis był powodem krótkotrwałego zrywu właścicieli psów, kiedy w roku 2017 przy wejściach do rezerwatów znajdujących się w obrębie miasta stołecznego Warszawy (na przykład Lasu Kabackiego, Lasu Bielańskiego) pojawiły się tabliczki zabraniające wstępu tym zwierzętom. Warto dodać, że przepis nie był nowy - nowe były jedynie tabliczki zakazu oraz patrole straży miejskiej monitorujące obecność psów w lesie i pouczające właścicieli ${ }^{63}$. Przedstawiciele Regionalnej Dyrekcji Ochrony Środowiska w Warszawie tłumaczyli w mediach, że zakaz obowiązywał od dawna, tylko nie był egzekwowany ${ }^{64}$. To wyjaśnienie - wskazujące na nieegzekwowanie obowiązującego prawa - stanowi doskonałe podsumowanie sytuacji psów i ich właścicieli w Polsce. Chociaż ograniczenia nakładane na nich zdają się dotkliwe - w większości miast należy prowadzić psy na smyczy oraz sprzątać po nich, w całym kraju obowiązuje zakaz spuszczania ich ze smyczy w Lasach Państwowych oraz wprowadzania do rezerwatów - to życie właścicieli nie jest aż tak trudne, ponieważ przepisy te są w znacznej mierze martwe. W roku 2017 sytuacja w Warszawie przez chwilę przypominała tę z USA w latach 90., czyli nagłe rygorystyczne egzekwowanie istniejących przepisów, które w Stanach Zjednoczonych wywołało polityczną mobilizację środowiska właścicieli psów oraz dążenie do tworzenia psich parków. W Polsce długoterminowa mobilizacja jednak nie nastąpiła, w znacznej mierze ze względu na powrót do stanu wyjściowego. W 2019 roku prasa lokalna narzekała już nie na obostrzenia w dostępie psów do lasu, ale na biegające luzem czworonogi. „Przegląd Piaseczyński” grzmiał: „Psy terroryzują biegaczy w Lesie Kabackim”. ${ }^{65}$ Znaki zakazu pozostały, lecz zniknęły patrole straży miejskiej. Dodatkowo w 2018 roku zmodyfikowano regulamin utrzymania czystości w mieście w sposób, który pozwala na legalne spuszczenie psa ze smyczy, o ile pozostaje on pod kontrolą swojego opiekuna ${ }^{66}$. Właściciele psów w Polsce nie są więc aż tak zdesperowani jak ci w USA, którzy zdali sobie sprawę, że nie ma w ich mieście miejsca, gdzie mogliby pozwolić zwierzęciu się wybiegać bez realnej groźby otrzymania wysokiego mandatu.

Jak wspomniano wcześniej, wzrost liczby parków w Polsce jest skorelowany w czasie z wprowadzeniem budżetu obywatelskiego. W Warszawie z wymienionych powyżej dwudziestu pięciu parków dwa zostały utworzone z budżetu obywatelskiego na rok 2015, sześć - na rok 2016, sześć - na rok 2017, pięć - na rok 2018 i jeden - na rok 201967. W roku 2016 jeden warszawski park, PSAdyba, powstał w ramach tak zwanej Inicjatywy Lokalnej, czyli formy współpracy samorządu z gminą na rzecz lokalnej społeczności. Z danych tych wynika jasno, że wybiegi dla psów są 
pożądane przez ich okolicznych opiekunów, którzy masowo głosują na projekty parków. Ten pozytywny stosunek do psich wybiegów jest wzmacniany przez samorządy i lokalne media, które w psich parkach widzą przede wszystkim potencjalne rozwiązanie sporu o psie odchody zanieczyszczające trawniki oraz konfliktów dotyczących dostępu tych zwierząt do części wspólnych terenów zielonych, zwłaszcza placów zabaw dla dzieci. W 2016 roku, przy okazji dyskusji nad projektami budżetu obywatelskiego dla Białołęki, na lokalnym portalu „Tu Białołęka” pisano: „Psie parki sprawdzają się w miastach nieźle - psy nie przeszkadzają spacerowiczom, są oddzielone od osób postronnych, a jednocześnie mogą swobodnie biegać i się bawić. Przy okazji zostaje wyeliminowany kłopot psich odchodów na trawnikach - niestety, nie wszyscy właściciele czworonogów sprzątają po swoich pupilach" ". Podobną argumentacją posługują się sami pomysłodawcy zgłaszanych projektów psich wybiegów. Autor jednego z nich, na warszawskiej Chomiczówce (projekt numer 984 na rok 2019), napisał: „Z jednej strony zaspokoi to [wybieg - J.W.] właścicieli czworonogów oraz ich pupilów skarżących się na brak takiego miejsca na Chomiczówce, z drugiej zaspokoi tych mieszkańców, którym nie podoba się, że psy biegają często po osiedlu «samopas»"69.

Uderza tutaj wiara w magiczną wprost moc ogrodzeń: wizja wyłaniająca się z tekstów promujących parki to idylla, w której dzieci bawią się na swoim ogrodzonym placu zabaw, psy na ogrodzonym wybiegu, a dorośli siedzą na kocyku położonym na czystej trawie oraz z radością przyglądają się harcom jednych i drugich. Jest to, rzecz jasna, pewien fantazmat, w którym ogrodzenie gra ogromną rolę w organizacji przestrzeni - w sposób uporządkowany wyznacza sekcje przynależne poszczególnym gatunkom oraz stanowi gwarancję czystości i bezpieczeństwa. W artykule dotyczącym otwartego w 2016 roku psiego parku w Opolu jego użytkowniczka, która jest jednocześnie mamą trzyletniej córki, ze zrozumieniem wypowiadała się o celowości podziału przestrzeni: „To chyba oczywiste, że park dla psów jest przede wszystkim dla zwierząt, a dzieci powinny się bawić na placu zabaw, który jest niedaleko". Sam artykuł, w którym pojawia się ta opinia, jest zatytułowany Rodzicu - psi park to nie plac zabaw! $!^{70}$. Przytaczane są w nim skargi użytkowników wybiegu na wchodzące na ten teren dzieci. Polskie psie parki opisywane są często jako place zabaw dla psów: w budżetach partycypacyjnych projekty psich wybiegów sąsiadują nieraz z placami zabaw dla dzieci (lub siłowniami na świeżym powietrzu). Zdarza się, że głosowania przeradzają się w starcia „rodziców” i „psiarzy”. Jeden z komentarzy pod niedawnym artykułem dotyczącym potencjalnej budowy parku dla psów w Pabianicach oddaje istotę tego sporu:

Pan prezydent robi wszystko dla pabianiczan mających dzieci (i chwała mu za to), ale niektórzy mają już dzieci dorosłe i ten pies to jedyne stworzenie w domu, które jest traktowane jak członek rodziny. Jest nas spora rzesza, jak ktoś to nazwał, „pchlarzy” i bylibyśmy bardzo wdzięczni (mam na myśli przyszłe wybory) za wygospodarowanie takiego miejsca ${ }^{71}$.

Strony sporu to mieszkańcy rodzice oraz mieszkańcy właściciele psów. Po pierwsze, w tym rozróżnieniu ginie część wspólna obu grup, a po drugie, obie są postrzegane jako zaangażowane w próby pozyskania od władz środków na zagospodarowanie przestrzeni w sposób, który automatycznie tworzy z nich dwa wrogie obozy. Chociaż analogie między placami zabaw dla dzieci i parkami dla psów pojawiają się w argumentacji wychodzącej od samych właścicieli czworonogów, zupełnie nieobecna - przynajmniej w dyskursie publicystycznym - jest koncepcja commons jako przestrzeni współdzielonej przez zwierzęta oraz ludzi. Zarówno rodzice, jak i psiarze opowiadają się za dzieleniem przestrzeni.

Analogie między placami zabaw dla dzieci i parkami dla psów mają również wpływ na organizację przestrzeni w obrębie polskich parków tego typu oraz na ich późniejsze funkcjonowanie. Amerykańskie parki są zwykle wyposażone w ławki i stoliki dla właścicieli, nie w sprzęty dla psów (il. 1 - Ohlone Dog Park). Tymczasem nieodłącznym wręcz elementem parków polskich stały się urządzenia przypominające przeszkody do agility - odpowiedniki sprzętów dla dzieci na placu zabaw (il. 2 - park Polana Hutnik). Analogia między emocjonalnym stosunkiem do dzieci i psów zostaje tutaj rozszerzona - zresztą w sposób zupełnie sprzeczny z obecnym stanem wiedzy etologicznej - na analogię potrzeb. Montowanie sprzętów do zabawy zdaje się też mieć związek z formułą finansowania wybiegów: przedsięwzięcia tańsze w realizacji nie mają 


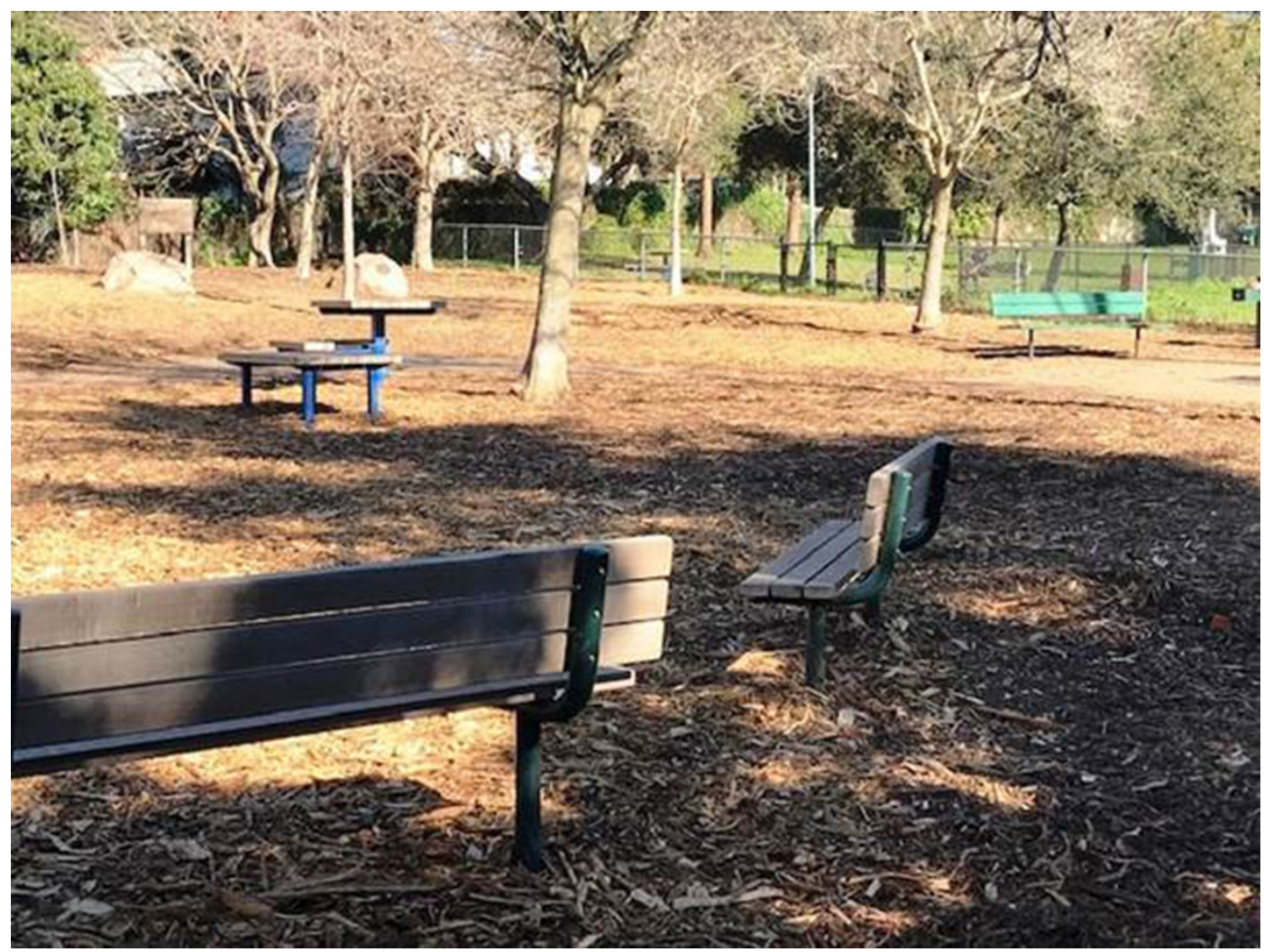

II. 1. Ohlone Dog Park. Fot. Joanna Ziarkowska

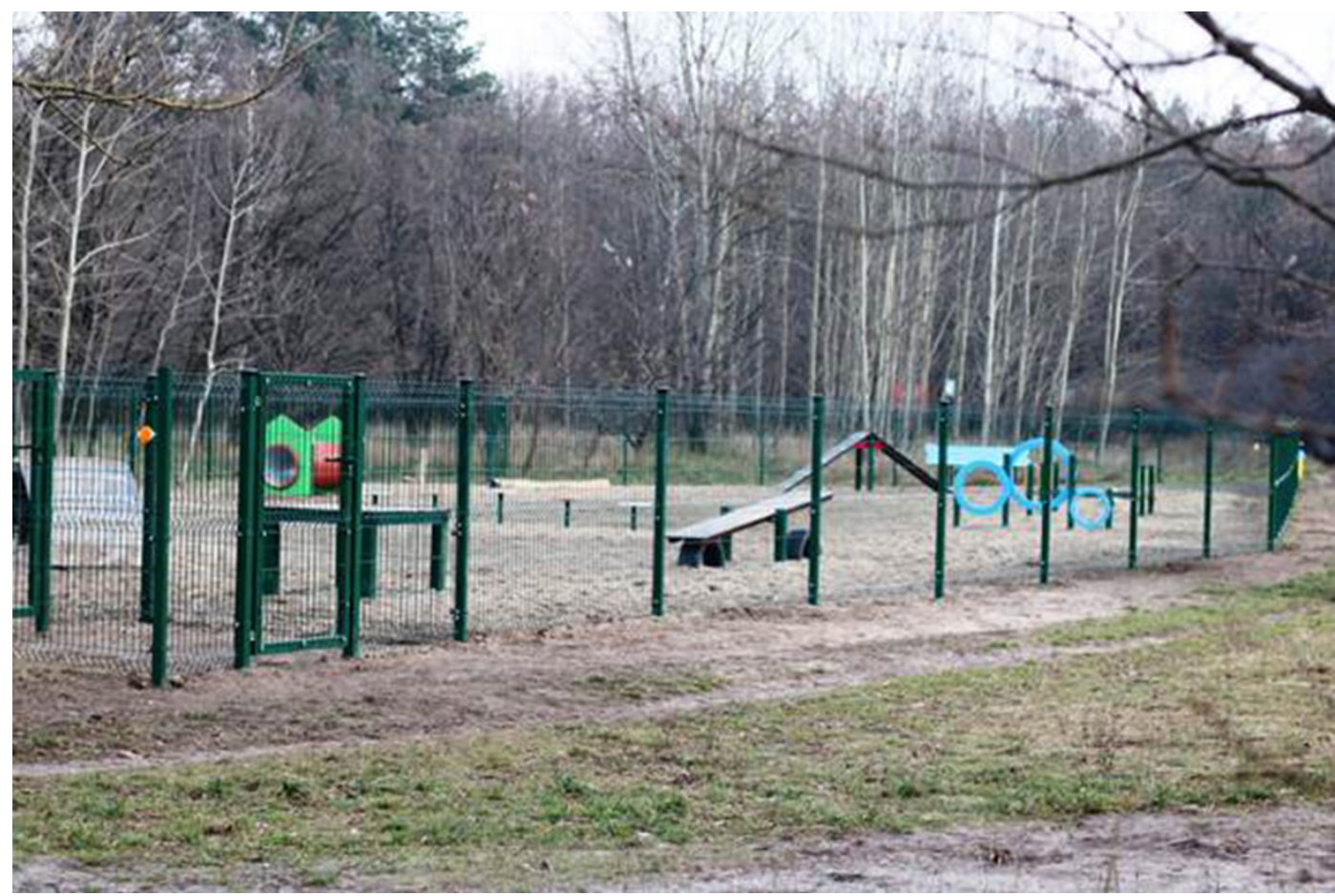

II. 2. Polana Hutnik. Fot. Urszula Charytonik 
większych szans na uzyskanie finansowania niż projekty bardziej kosztowne. Samo wygrodzenie terenu o powierzchni około 700-1500 metrów kwadratowych, a tyle średnio mają zgłaszane w Warszawie projekty, kosztuje stosunkowo niewiele, zwykle maksymalnie 20000 złotych. Projekty wybiegów dla psów zgłaszane w ramach budżetów partycypacyjnych nie różnią się jednak kosztorysem od projektów infrastrukturalnych dla grup ludzkich (na przykład placów zabaw dla dzieci, siłowni na świeżym powietrzu) właśnie ze względu na wpisanie w wydatki torów przeszkód. I tak na przykład w zwycięskim projekcie parku zlokalizowanego na Saskiej Kępie w Warszawie, zgłoszonym w ramach budżetu obywatelskiego dzielnicy Praga-Południe na rok 2019, w całkowitym jego koszcie 112000 złotych blisko połowę stanowił koszt przeszkód oraz ich montażu ${ }^{72}$. Bogata i kosztowna infrastruktura psich wybiegów zdaje się zrównywać rangę projektów małej architektury miejskiej przeznaczonej dla zwierząt z tymi dla ludzi. Projekty te są postrzegane jako równorzędni konkurenci.

Przeszkody znajdujące się na wielu wybiegach są ostro krytykowane przez profesjonalistów zajmujących się szkoleniem psów. Nie są to regulaminowe przeszkody do agility, nie nadają się więc do treningu pod kątem zawodów. Niespecjalnie nadają się również do wykorzystania rekreacyjnego, bo często ustawione są w sposób, który uniemożliwia psom korzystanie z nich. W Warszawie najgorzej chyba rozplanowanym parkiem jest wybieg na ulicy Stalowej (budżet partycypacyjny na rok 2015), gdzie liczne przeszkody stłoczono tak, że żaden pies nie da rady przez nie przeskoczyć. Dodatkowo duża liczba sprzętów generuje wysokie koszty utrzymania bądź łączy się z ryzykiem dewastacji. Na ulicy Stalowej przeszkody zostały zdewastowane już w pierwszych tygodniach funkcjonowania parku. Nieformalne obserwacje terenowe autorki wykazują także, że przeszkody nie są wykorzystywane zgodnie z przeznaczeniem. Służą najwyżej jako kryjówki i punkty orientacyjne w psich gonitwach. Nie jest jednak moim zamiarem przekształcenie tego artykułu w rozprawę o poprawnym planowaniu parków dla psów, tylko analiza kulturowej warstwy funkcjonowania wybiegów.

Aby dopełnić tej analizy, przychylność wobec parków dla psów w Polsce należy odnieść do entuzjazmu dla płotków i ogrodzeń, który charakteryzuje polskie miasta od roku 1989. Stworzenie psiego parku to przecież wprowadzenie kolejnego ogrodzenia w krajobraz miejskich osiedli podzielonych płotami. Jak na ironię od kilku dekad płotki wewnątrzosiedlowe wpisują się w krajobraz postsocjalistycznych osiedli, gdzie wygradzają skrawki trawników dookoła bloków, by chronić je przed psami. W psich parkach ogrodzenia zmieniają charakter: z przeciwników czworonogów stają się ich sojusznikami. Jednak płoty, którym poświęcono w ostatnich latach najwięcej uwagi, to te na zewnątrz osiedli - stawiane dookoła nowych domów budowanych przez prywatnych deweloperów. Jak piszą badacze osiedli zamkniętych z ostatnich dekad, mają one odgrodzić mieszkańców od tego, co jest postrzegane jako niebezpieczne, i stworzyć poczucie prestiżu oraz luksusu przy jednoczesnym budowaniu wspólnej tożsamości osób z wewnątrz jako wyjątkowych i wyróżniających $\operatorname{się}^{73}$. Te obserwacje mogą mieć pewne odniesienie do amerykańskich psich parków, przynajmniej tych powstających w społecznościach, w których dochodzi do gentryfikacji. Płot, a często także opłata członkowska, stanowi gwarancję ochrony przed napierającą ze wszystkich stron miejską biedotą. W Polsce tak jednak nie jest: powstawanie psich parków zwykle nie jest powiązane z klasycznie rozumianą gentryfikacją, są one ogólnodostępne i budowane często na obrzeżach postsocjalistycznych blokowisk. Jednocześnie polskie parki absolutnie nie są postrzegane jako psie getta, tak jak w Wielkiej Brytanii. Wręcz przeciwnie, przez swoich użytkowników są odbierane jako element architektury krajobrazu, który w bardzo namacalny sposób podkreśla wagę więzi człowieka z psem. Można powiedzieć, że proces tworzenia grodzonych wybiegów jest jednak elementem gentryfikacji definiowanej szerzej niż tylko wypieranie biedniejszych mieszkańców przez bogatych - rozumianej raczej jako podporządkowywanie przestrzeni gustom i potrzebom klasy średniej. Miejska klasa średnia uważa powstawanie psich parków za proces pożądany, czemu daje wyraz w głosowaniach na projekty wybiegów.

Psie parki są przez zwolenników postrzegane jako pomnik znaczenia tego zwierzęcia w polskim społeczeństwie. Niestety, jak każdy pomnik parki wymagają konserwacji i ciągłych nakładów finansowych: zgłaszane są problemy dotyczące ich dewastacji, zaśmiecania, nieodbierania odpadów, naturalnej degradacji trawiastego podłoża, wszechobecnego błota oraz niedociągnięć na etapie planowania (brak oświetlenia - Polana Hutnik, dzielnica Bielany, Warszawa; brak 
odpływu wody z terenu - Park Leśnika, dzielnica Gocław, Warszawa). W Polsce jak dotąd nie powstały stowarzyszenia użytkowników biorących na siebie zarządzanie konkretnymi wybiegami; wybiegi nie spełniają więc funkcji swoistej szkoły aktywności obywatelskiej, jaką stają się w USA. W Polsce obowiązek ich utrzymania spada na gminy.

W roku 2020 (budżet na rok 2021) w Warszawie zgłoszono siedem projektów ogrodzonych wybiegów dla psów, co sugeruje, że mieszkańcy w dalszym ciągu dostrzegają potrzebę tworzenia tego rodzaju obiektów. Jednym z niewielu miejsc, gdzie odnotowano protesty, nie przeciwko obecności psów, lecz płotów, było Pole Mokotowskie (w trakcie konsultacji społecznych w latach 2015-2017 dotyczących projektu jego rewitalizacji). W wyniku konsultacji ustalono, że na Polu Mokotowskim znajdą się strefy przeznaczone dla psów, nie będą one jednak odgrodzone od reszty parku płotem ${ }^{74}$. Koncepcja ogrodzonego wybiegu pojawiła się w dyskusji z inicjatywy samych właścicieli czworonogów. Pomysł został skrytykowany przez okolicznych mieszkańców nie ze względu na smród czy zagrożenie niesione przez zwierzęta, ale z powodu rozpoznania problemu potencjalnego wykluczenia niektórych mieszkańców z przestrzeni wspólnej, zwłaszcza w kontekście planowanego wykorzystania wygrodzonej powierzchni do prowadzenia płatnych zajęć. W liście opublikowanym w „Gazecie Wyborczej” mieszkańcy pisali:

Deklarujemy, że taki sposób projektowania funkcji terenów publicznych budzi nasz sprzeciw jako przejaw neoliberalnego podejścia do wspólnej przestrzeni. Teren publiczny powinien być tak samo dostępny dla wszystkich mieszkańców, niezależnie od zasobności portfela. W tym projekcie widzimy zagrożenie polegające na segregacji użytkowników przestrzeni. Projekt proponuje przestrzeń grodzoną, oderwaną funkcjonalnie i estetycznie z całości parku Pole Mokotowskie ${ }^{75}$.

Ten list to jeden z niewielu głosów sprzeciwu, który nie pada ze strony przeciwników psów w przestrzeni miejskiej, tylko zwolenników demokracji uczestniczącej oraz osób przeciwnych dalszemu grodzeniu przestrzeni ogólnodostępnej, urban commons. Jest to jednak głos odosobniony i nieprzypadkowo sformułowano go w sprawie wybiegu w postrzeganej jako inteligencka dzielnicy stołecznej Warszawy. Nie można zapominać, że większość wybiegów powstaje w ramach budżetów obywatelskich: są to projekty zwycięskie, wybrane głosami mieszkańców. Ruch tworzenia psich parków przybiera na sile w średnich i mniejszych miastach, choć zdarzają się tam konflikty podobne do tego z Kansas City. Mieszkańcy Suwałk oraz Płocka narzekają na smród i hałas potencjalnie związane z funkcjonowaniem wybiegów. W obu przypadkach budowy zostały wstrzymane, choć projekty uzyskały wystarczająco dużo głosów poparcia. Podobny konflikt rozwija się również w Iławie, gdzie w lutym 2020 roku miała miejsce burzliwa konfrontacja zwolenników i przeciwników budowy wybiegu. Wśród głosów sprzeciwu można odnotować następujące argumenty: „Czy jeśli mieszkańcy zagłosują, by na Starym Mieście zrobić wysypisko śmieci, to czy tak właśnie się stanie?”; „Jak będą tu wypoczywać ludzie starsi? Przecież będzie tu hałas”; „Czy psy są dla władz miasta ważniejsze niż ludzie, niż seniorzy?”76. Napięcia w mniejszych miastach są zdecydowanie większe niż w Warszawie czy Krakowie, a podawane przez przeciwników argumenty mają wydźwięk modernizacyjno-higieniczny (porównanie wybiegu z wysypiskiem śmieci); niektórzy wyrażają także obawy przed wykluczeniem społecznym grup, które nie będą użytkownikami wybiegu (tutaj: seniorzy). Śledząc doniesienia z lokalnych mediów, można odnieść wrażenie, że kontrowersje związane z wybiegami w Polsce nie tylko nie słabną, lecz także stają się coraz silniejsze.

Celem tego artykułu nie jest, rzecz jasna, zajęcie stanowiska w trwających już sporach, ale ukazanie, jakkolwiek pobieżnie, ich złożoności: trzy kraje, trzy różne podejścia do regulacji obecności psów w przestrzeni miejskiej i trzy różne koncepcje dotyczące grodzonych psich parków. Regulacje obowiązujące w każdym z nich zdają się pokazywać, do jakiego stopnia sfera kulturowa przenika się ze sferą rozwiązań urbanistycznych, również w tak-zdawałoby się - pobocznym aspekcie, jak stosunek do zwierząt domowych, i jak rozmaite znaczenia można przypisywać temu samemu elementowi infrastruktury rekreacyjnej-ogrodzonemu płotem wybiegowi dla psów - w różnych kręgach kulturowych. W USA parki tworzone są przez grupy lokalnych aktywistów, którzy często napotykają na niechęć miejscowych władz. W Wielkiej Brytanii to 
lokalne władze wychodzą z inicjatywą tworzenia wybiegów, a opiekunowie psów odnoszą się do tych pomysłów z dużą rezerwą, bojąc się ograniczeń korzystania przez zwierzęta ze wspólnej przestrzeni nieogrodzonej, z urban commons. Natomiast w Polsce wybiegi tworzone są przez władze lokalne na wniosek samych opiekunów czworonogów, którzy koncepcję psich parków widzą jako ważny element współczesnych zmian - na lepsze - w relacji ludzie-psy. W omówionych wyżej przypadkach proces tworzenia parków jest uwikłany w szersze konflikty dotyczące relacji klasowych, rasowych, różnych definicji modernizacji oraz różnych definicji przestrzeni publicznej. Spory o wybiegi są uwikłane w te antagonizmy na wielu płaszczyznach i nie można kwestii psich parków rozpatrywać bez wzięcia pod uwagę ich wymiaru kulturowego. Dlatego też w artykule świadomie pominięta została literatura poradnikowa dotycząca planowania wybiegów oraz opracowania behawioralne o ich wpływie na zachowanie psów. Uwaga skupiona została na tym, czego w tego rodzaju literaturze - również potrzebnej - brakuje.

\section{PRZYPISY}

1 R. Coppinger, L. Coppinger, Dogs: A New Understanding of Canine Origin, Behavior and Evolution, ChicagoLondon 2002; R. Coppinger, M. Feinstein, How Dogs Work, Chicago-London 2015; C. Wynne, Dog is Love: Why and How Your Dog Loves You, New York-Boston 2019.

2 P. Atkins, Introduction, w: tenże (red.), Animal Cities. Beastly Urban Histories, Burlington 2012, s. 2. Fragmenty tej pracy w polskim tłumaczeniu w tym tomie, zob. Zwierzęce nieczystości i utrapienia w dziewiętnastowiecznym Londynie, przeł. J. Schollenberger.

3 M.J. Watts, Afterword: Enclosure, w: Ch. Philo, Ch. Wilbert (red.), Animal Spaces, Beastly Places: New Geographies of Human-Animal Relations, London 2000, s. 292.

4 E. Fudge, Pets, New York-London 2008, s. 19

5 Przytoczone później case studies konkretnych parków pochodza z nastepujących artykułów: S. Tissot, Of Dogs and Men: The Making of Spatial Boundaries in a Gentrifying Neighborhood, "City \& Community" 2011, nr 10(3), s. 265-284; J. Urbanik, M. Morgan, A Tale of Tails: The Place of Dog Parks in the Urban Imaginary, "Geoforum" 2013, nr 44, s. 292-302.

6 D. Matisoff, D. Noonan, Managing Contested Greenspace: Neighborhood Commons and the Rise of Dog Parks, "International Journal of the Commons" 2012, nr 6(1), s. 28-51. Matisoff i Noonan rozpatrują amerykańskie parki jako przykład nowoczesnej miejskiej przestrzeni wspólnej, podlegającej kolektywnym procesom zarządzania i kształtującej odpowiedzialność społeczną (ludzkich) użytkowników.

7 M. Foucault, Nadzorować i karać. Narodziny więzienia, przeł. T. Komendant, Warszawa 1998.

8 J. Włodarczyk, Genealogy of Obedience: Reading North American Dog Training Literature, 1850s-2000s, Boston-Leiden 2018, s. 201-202.

9 K. Konecki, Ludzie i ich zwierzęta. Interakcjonistyczno-symboliczna analiza społecznego świata właściciel zwierzat domowych, Warszawa 2005, s. 6.

10 Z podziękowaniami dla Polsko-Amerykańskiej Komisji Fulbrighta, która umożliwiła mi badania terenowe w USA w ramach grantu Senior Fulbright Research Award.

11 E. Klima, D. Stasiuk, Życie z psami w mieście, „Acta Universitatis Lodziensis: Folia Geographica-Socio-Oeconomica" 2017, nr 30, s. 65-84.

12 Dane dostępne na stronie Twój budżet, prowadzonej przez miasto stołeczne Warszawa, po skorzystaniu z wyszukiwarki projektów archiwalnych. Stan na luty 2020 roku, https://twojbudzet.um.warszawa.pl/ (dostęp: 5.02.2020).

13 J. Urbanik, M. Morgan, A Tale of Tails..., dz. cyt., s. 292

14 Jednostka miary, która odpowiada 0,348 metra.

15 Ohlone Dog Park, Berkley Plaques, http://berkeleyplaques.org/plaque/ohlone-dog-park/ (dostęp: 23.01.2019)

16 J. Walsh, Unleashed Fury: the Political Struggle for Dog-Friendly Parks, West Lafayette 2011, s. 27-34.

17 A.A. Patterson, Training Class for City's Dogs Proves Popular, "The New York Times”, 23.07.1944, s. B2

18 „Fala pogryzień" z lat 80. była już wielokrotnie analizowana jako przykład tak zwanej paniki moralnej. Zob. np. C. Molloy, Dangerous Dogs and the Construction of Risk, w: N. Taylor, T. Signal (red.), Theorizing Animals, Boston-Leiden 2011, s. 107-128. Tym, co do tej perspektywy dodają amerykańscy badacze związan z critical race studies, jest obserwacja, że zmiana wizerunku pitbulli z kochających psów domowych na dzikie bestie była powiązana z bardzo silnym skojarzeniem tych psów z Afroamerykanami. Zob. np. C.J. Kim, Dangerous Crossings: Race, Species and Nature in a Multicultural World, New York 2015; B. Boisseron, Afro-Dog, "Transition" 2015, nr 118, s. 17-18

19 J. Walsh, Unleashed Fury..., dz. cyt., s. 1-2 
20 Tamże, s. 73-74

21 Pets on Leashes Welcome in Billings Parks Beginning Wednesday, "Billings Gazette”, 30.01.2017, https:// billingsgazette.com/news/local/government-and-politics/pets-on-leashes-welcome-in-billings-parks-beginning-wednesday/article_b9bfa549-62da-582b-9e02-f0a8828efeca.html (dostęp: 23.01.2019).

22 J. Ford-Stewart, Dogs Win in Greenfield. Pets to Be Allowed in City Parks - with Restrictions, "Journal Sentinel", 2.05.2018, https://eu.jsonline.com/story/communities/southwest/news/greenfield/2018/05/02/ dogs-win-greenfield-pets-allowed-greenfield-parks-but-restrictions/572442002/(dostęp: 23.01.2019).

23 J. Urbanik, M. Morgan, A Tale of Tails..., dz. cyt., s. 296.

24 Parki, z których korzystałam w latach 2016-2017, zarządzane przez Zarząd Parków w Champaign w stanie Illinois, wymagały rocznej opłaty członkowskiej w wysokości 38 dolarów.

25 K. Armbruster, Dogs, Dirt and Public Space, w: J. Sorenson, A. Matsuoka (red.), Dog's Best Friend? Rethinking Canid-Human Relations, Montreal 2019, s. 123.

26 P. Atkins, Animal Cities..., dz. cyt., s. 28

27 J. Ford-Stewart, Dogs Win..., dz. cyt.

28 J. Urbanik, M. Morgan, A Tale of Tails..., dz. cyt., s. 299

29 M. Douglas, Czystość i zmaza, przeł. M. Bucholc, Warszawa 2007, s. 46

30 J. Urbanik, M. Morgan, A Tale of Tails..., dz. cyt., s. 299.

31 L. Berlant, M. Warner, Sex in Public, "Critical Inquiry” 1998, nr 24, s. 547-567; L. Duggan, The New Homonormativity: The Sexual Politics of Neoliberalism, w: R. Castronovo, D. D. Nelson (red.) Materializing Democracy: Toward a Revitalized Cultural Politics, Durham-London 2002, s. 175-194.

32 K. Armbruster, Dogs, Dirt..., dz. cyt., s. 119.

33 S. Tissot, Of Dogs and Men..., dz. cyt., s. 265.

34 Tamże, s. 272-273

35 Tissot nie wspomina o możliwości istnienia cześci wspólnej tych dwóch zbiorów: bezdomnych i właścicieli psów. Temat bezdomnych właścicieli zwierząt domowych i ich podwójnego wykluczenia (schroniska dla bezdomnych w USA nie przyjmują osób ze zwierzętami domowymi) jest poruszany w innych publikacjach, zob. np. A.H. Kidd, R.M. Kidd, Benefits and Liabilities of Pets for the Homeless, "Psychological Reports" 1994 , nr 74, s. 715-722.

36 S. Tissot, Of Dogs and Men..., dz. cyt., s. 266

37 H.J. Nast, Puptowns and Wiggly Fields: Chicago and the Racialization of Pet Love in the Twenty-First Century, w: R. Schein (red.), Landscape and Race in the United States, New York 2006, s. 240.

$38 \mathrm{~J}$. Terruso, If It Seems as if Dogs are Everywhere in Philly's Gentrifying Neighborhoods, They are, "The Inquirer", z 26.07.2017, http://www.philly.com/archive/julia terruso/if-it-seems-like-dogs-are-everywhere-in-phillys-gentrifying-neighborhoods-they-are-20170726.html (dostęp: 25.01.2019).

39 Warto dodać, że charakter zabudowy i samo rozmieszczenie parku są zupełnie inne w opisywanym przez Urbanik i Morgan studium przypadku z Kansas City, w analizowanym przez Tissot przypadku z Bostonu (Dover) oraz wspomnianym powyżej przedsięwzięciu z Point Breeze. W Kansas City, jak w wielu średniej wielkości miastach o mało zwartej zabudowie, planowany park miał być zlokalizowany w dzielnicy domków jednorodzinnych zamieszkiwanej przez klasę średnią. W Bostonie, Chicago i Filadelfii kontrowersyjne parki powstawały w obszarze zwartej zabudowy miejskiej, która jednocześnie poddawana była procesowi gentryfikacji.

40 K. Armbruster, Dogs, Dirt..., dz. cyt., s. 127.

41 H. Ritvo, The Animal Estate. The English and Other Creatures in the Victorian Age, Cambridge-London 1987, s. 82-121; N. Pemberton, M. Worboys, J.-M. Strange, The Invention of the Modern Dog. Breed and Blood in Victorian Britain, Baltimore 2018, s. 1-23.

42 P. Howell, At Home and Astray: The Domestic Dog in Victorian Britain, Charlottesville, VA 2015, s. 170.

43 Tamże, s. 171-172.

44 M. Worboys, N. Pemberton, Mad Dogs and Englishmen: Rabies in Britain, 1830s-2000s, New York 2007, s. $133-162$

45 W roku 1953 wprowadzono Protection of Livestock Act, akt prawny chroniący zwierzęta gospodarskie Ustanawiał on kary dla właścicieli psów, które niepokoją (atakują lub gonią) zwierzęta gospodarskie. Ustawa ta, obowiązująca do dzisiaj, nie daje właścicielowi zwierząt gospodarskich prawa do zastrzelenia psa. Zob. Protection of Livestock Act, http://www.legislation.gov.uk/ukpga/Eliz2/1-2/28 (dostep: 21.01.2019).

46 N. Pemberton, The Burnley Dog War. The Politics of Dog-Walking and the Battle over Public Parks in Post-Industrial Britain, "Twentieth-Century British History” 2017, nr 28(2), s. 239.

47 Pierwsze akty prawne nakazujące właścicielom sprzątanie odchodów swoich psów pojawiają się w Wielkiej Brytanii dopiero w latach 90. XX wieku. Analogiczne przepisy zostały wprowadzone w niektórych miastach USA już pod koniec lat 70. Pionierskim miastem był Nowy Jork pod rządami burmistrza Edwarda Kocha, który zasłynął jako wyznawca tak zwanej teorii wybitych okien, czyli walki z drobnymi wykroczeniami jako elementu szerszej strategii walki z wysoką przestępczością. W 1978 roku Koch wprowadził obowiązek sprzątania po psach, znany jako pooper scooper law. Przepis ten nie pozostał martwym 
aktem prawnym. Wręcz przeciwnie, był rygorystycznie egzekwowany przez władze miasta. Zob. M. Brandow, New York's Poop Scoop Law: Dogs, the Dirt and Due Process, West Lafayette, IN 2008.

48 N. Pemberton, The Burnley Dog..., dz. cyt., s. 240.

49 Tamże, s. 248

50 Warto jednak dodać, że nie wszystkie wprowadzone w 1977 roku zakazy zostały cofnięte, a Burnley do tej pory pozostaje jednym z miast, które najbardziej rygorystycznie regulują kwestię wyprowadzania psów. W dalszym ciągu obowiązuje zakaz wprowadzania ich do dwóch parków, a od roku 2010 istnieje również nakaz prowadzenia ich na smyczy w obrebie cmentarzy, krematoriów oraz terenów kościelnych. Zob. Dogs to Remain Banned at Burnley Parks, "Lancashire Telegraph", 11.11.2010, https://www.lancashiretelegraph. co.uk/news/8629385.dogs-remain-banned-burnley-parks/ (dostęp: 3.02.2020).

51 E.M. Wood, Agrarne początki kapitalizmu, przeł. E. Robakiewicz, „Praktyka Teoretyczna” 2017, nr 26 , s. $350-353$.

52 Ch. Borch, M. Kornberger (red.), Urban Commons: Rethinking the City, Oxon-New York 2015

53 P. Marcuse, From Justice Planning to Commons Planning, w: tenże i in. (red.), Searching for the Just City, Abingdon-New York 2009, s. 91

54 J. Metzger, The City is Not a Menschenpark: Rethinking the Tragedy of the Urban Commons beyond the Hu man/Non-Human Divide, w: Ch. Borch, M. Kornberger (red.), Urban Commons.... dz. cyt, s. 22-46. Oto oryginalny tekst pierwszej strofy anonimowego, popularnego siedemnastowiecznego wierszyka skierowanego przeciwko grodzeniom: "The law locks up the man or woman/Who steals the goose off the common/ But leaves the greater villain loose/Who steals the common from the goose".

55 P. Wedderburn, Dog Parks and Dog-free Zones? The UK of the Future, "The Telegraph", 24.10.2016, https:// www.telegraph.co.uk/pets/news-features/dog-parks-and-dog-free-zones-the-uk-of-the-future/ (dostęp: 22.12.2018).

56 Dogs Trust, Restrictions on Dogs in Public Spaces, https://www.dogstrust.org.uk/news-events/issues-campaigns/restrictions-on-dogs-in-public-spaces/ (dostęp: 22.01.2019).

57 The Kennel Club, Dog Parks, https://www.thekennelclub.org.uk/our-resources/media-centre/issue-statements/dog-parks/(dostęp: 22.01.2019).

58 K. Armbruster, Dogs, Dirt..., dz. cyt., s. 118.

59 P. Marcuse, From Justice Planning..., dz. cyt., s. 94-96.

60 M.P. Pręgowski, J. Włodarczyk, Trzecia Rzeczpospolita czworonożna: badajac psy i ludzi we współczesnej Polsce, w: ciż (red.), Pies też człowiek? Relacje ludzi i psów we współczesnej Polsce, Gdańsk 2014, s. 3-43. W tym artykule prześledzono debatę dotyczącą sprzątania po psach, która prowadzona była w mediach w 2013 roku.

61 W Nowym Jorku (jednym z bardziej postępowych miast USA pod względem "psiolubności") metrem mogą jeździć wyłącznie psy przewożone w torbach transportowych. Przepis miał na celu ograniczenie możliwości przejazdu z dużymi psami. W internecie można znaleźć zdjęcia ogromnych dogów niemieckich i owczarków niemieckich przewożonych w równie ogromnych plastikowych torbach z wyciętymi otworami na nogi. Nowy Jork jest jednak jednym z niewielu miast w USA, które posiada system komunikacji publicznej sprawny na tyle, by umożliwić życie bez samochodu. Zasadą domyślną w innych miastach jest założenie, że jeśli ktoś potrzebuje pojechać gdzieś z psem, po prostu używa do tego samochodu.

62 O zakazie wprowadzania psów na szlaki i ścieżki przyrodnicze, Bieszczadzki Park Narodowy - serwis internetowy, 8.08.2012, https://www.bdpn.pl/index.php?option=com_content\&task=view\&id=1109\&/temid=54 (dostep: 27.01.2019).

63 M. Siesicka-Osiak, Nie dla psa Kabaty. Czworonogi maja zakaz wejścia do lasu!, "Halo Ursynów”, 13.12.2017, https://www.haloursynow.pl/artykuly/nie-dla-psa-kabaty-czworonogi-maja-zakaz-wejscia-do-lasu, 8838.htm (dostep: 3.02.2020).

64 J. Grela, Z psem do rezerwatu nie wolno, „Przegląd Piaseczyński”, 20.12.2017, wersja online: https://www. przegladpiaseczynski.pl/spoleczenstwo/z-psem-do-rezerwatu-nie-wolno/ (dostęp: 27.01.2019)

65 T. Wojciuk, Psy terroryzuja biegaczy w Lesie Kabackim, „Przeglad Piaseczyński” 24.05.2019, wersja online: https://piasecznonews.pl/psy-terroryzuja-biegaczy-w-lesie-kabackim/ (dostęp: 3.02.2019).

66 Uchwała nr LXI/1631/2018 Rady Miasta Stołecznego Warszawy z dnia 8 lutego 2018 roku.

67 Dane te sa dostepne na stronie: twojbudzet.um.warszawa.pl po skorzystaniu z wyszukiwarki projektów przeznaczonych do finansowania. Co ciekawe, w roku 2018 i 2019 wśród zgłoszonych projektów psich parków przeważyły te, które nie otrzymały dofinansowania (w 2018 roku: jedenaście zgłoszonych projektów, pięć wybranych do realizacji w głosowaniu, w 2019 roku: cztery zgłoszone projekty, jeden wybrany w głosowaniu). Te wyniki zdają sie sugerować, że stolica powoli nasyca sie wybiegami dla psów lub że mieszkańcy zaczynają dostrzegać, iż ich tworzenie nie jest rozwiązaniem konfliktów między właścicielami czworonogów a mieszkańcami, którzy ich nie mają. Choć nie istnieją dokładne dane ogólnopolskie, w danych cząstkowych (m.in. strona: www.psipark.pl) można w latach 2016-2019 dostrzec trend do tworzenia wybiegów w coraz mniejszych miejscowościach.

68 Psi park na Tarchominie - tylko gdzie?, Tu Białołęka, 5.04.2016, http://tustolica.pl/psi-park-na-tarchominie-tylko-gdzie 72915 (dostep: 27.01.2019).

69 twojbudzet.um.warszawa.pl, projekt numer 984 na rok 2019 (dostęp: 3.02.2019).

70 A. Wyspiańska. Rodzicu - psi park to nie plac zabaw!, Portal Opole Nasze Miasto, 27.07.2017, http://opole.naszemiasto.pl/artykul/rodzicu-psi-park-to-nie-jest-plac-zabaw,3810706,artgal,t,id,tm.html (dostep: 29.01.2019). 
71 Wybieg dla psów? Nie stać nas, „Życie Pabianic”, 17.01.2019, https://www.zyciepabianic.pl/informacje/ pabianice/nie-stac-nas-na-wybieg-dla-psow.html?fbclid=IwAR1qQcuJ7N1BaOUPn-sZMTUdeBRXUOKMnNrgYIKCzlaQhrP5ub0vZbh7C_g (dostęp: 28.01.2019).

72 Dog park (skwerek psi), Budżet partycypacyjny Warszawa 2018, https://app.twojbudzet.um.warszawa. pl/projekt/16357 (dostęp: 28.01.2019).

73 Zob. np. J. Gądecki, Za murami. Osiedla grodzone w Polsce - analiza dyskursu, Wrocław 2009

74 M. Szaflarski, Pole Mokotowskie: awantura o psie wybiegi, "Gazeta Wyborcza", 22.04.207, wersja online: http://warszawa.wyborcza.pl/warszawa/7,54420,21672665,pole-mokotowskie-awantura-o-psie-wybiegi.html (dostęp: 28.02.2019)

75 I. Janikowska-Lipszyc, M. Środoń, D. Jarecka, Dlaczego protestujemy przeciw wybiegowi dla psów na Polu Mokotowskim, "Gazeta Wyborcza. Warszawa", 1.04.2015, wersja online: http://warszawa.wyborcza.pl/ warszawa/1,34862,17691918,Dlaczego_protestujemy_przeciw_wybiegowi_dla_psow_na.html (dostęp: 28.01.2019)

76 Wielkie emocje na spotkaniu władz Iławy z przeciwnikami wybiegu dla psów przy "bagienku”, Infoilawa,pl, 7.02.2020, infoilawa.pl/aktualności/item60094-wielkie-emocje-na-spotkaniu-wladz-ilawy-z-przeciwnikami-wybiegu-dla-psow-przy-bagienku-zobacz-zdjecia-i-wideo (dostęp: 13.02.2020). 



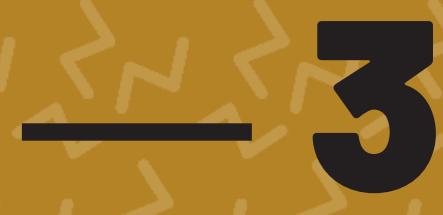

\section{Analizy \\ i interpretacje}




\title{
Aleksander Wójtowicz
}

\author{
Gawron, czyli intruz \\ w mieście \\ (wypisy z literatury ornitologicznej)
}

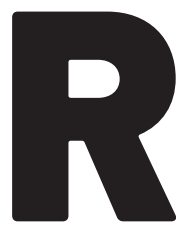

ozporządzenie Ministra Środowiska z dnia 16 grudnia 2016 roku w sprawie ochrony gatunkowej zwierząt uwzględnia 426 gatunków ptaków. Dokument, który został uporządkowany w zgodzie z legislacyjnymi standardami oraz współczesną wiedzą ornitologiczną, zawiera ciągnący się przez wiele stron wykaz nazw w języku polskim i łacińskim. Od tej monotonnej struktury jest tylko jedno odstępstwo, ponieważ pod pozycją 323 został skatalogowany ptak, dla którego sejmowi prawnicy ukuli specjalną formułę. Według niej ochronie podlegają wyłącznie „osobniki poza obszarem administracyjnym miast”.1.

Chodzi o gawrona. Trudno jednak w tym przypadku mówić o jakimkolwiek „wyróżnieniu”. Wręcz przeciwnie - raczej o częściowym wyjęciu spod prawa, tym bardziej ewidentnym, że nie przypadło ono w udziale żadnemu innemu gatunkowi, jaki został wymieniony we wspomnianym wykazie. Ze skonstruowanego w ten sposób zapisu wywnioskować można, że na terenach zurbanizowanych obecność gawrona jest uznawana za niepożądaną. Wynika to jednak nie z jego codziennego zachowania w terenach miejskich, bo jest przecież o wiele spokojniejszy choćby od agresywnych wron, ale z faktu, że w okresie lęgowym tworzy w parkach hałaśliwe kolonie. Kłopoty, jakie wynikają z takiego sąsiedztwa, w sposób przejaskrawiony opisuje współczesny dyskurs publicystyczny; artykuły prasowe przedstawiają gawrona - podobnie zresztą jak i inne gatunki krukowatych - jako intruza zanieczyszczającego przestrzeń miejską i zakłócającego spokój mieszkańców. Dobitnie świadczą o tym utrzymane w alarmistycznej poetyce tytuły artykułów: Tarnów. Na cmentarzu w Krzyżu strzelają z armatki, bo gawrony paskudzq na groby; Radny Marcin Fica wypowiedział wojnę stadu gawronów, które przesiadują na drzewach przy ulicy Wojska Polskiego oraz Wileńskiej, w rejonie Budowlanki; Wrony atakuja przechodniów; Wrony atakują ludzi i psy. Nawet w środku miasta. „Goniła się za nami i darła jak dzika”. Wyliczenie takich sformułowań można by kontynuować jeszcze długo, ale już te kilka przykładów wystarczy, aby zauważyć, że przywołane sformułowania powielają katastroficzne schematy, jakie w ciągu ostatnich paru dekad dość mocno zadomowiły się w kulturze popularnej, operującej różnego rodzaju strategiami tematyzowania zagrożeń płynących ze świata natury. Gawron i jego pobratymcy to jednak stworzenia mniej groźne niż drapieżne ssaki bądź jadowite owady, ale za to o wiele bardziej kłopotliwe w życiu codziennym, bo notorycznie zaburzające spokój i higienę miast. W publicystycznym portrecie ptaka-intruza, który „,nawet w środku miasta” potrafi „drzeć się jak dziki”, dostrzec można przesłonięte przez publicystyczną kreskę cechy ukształtowane 
12

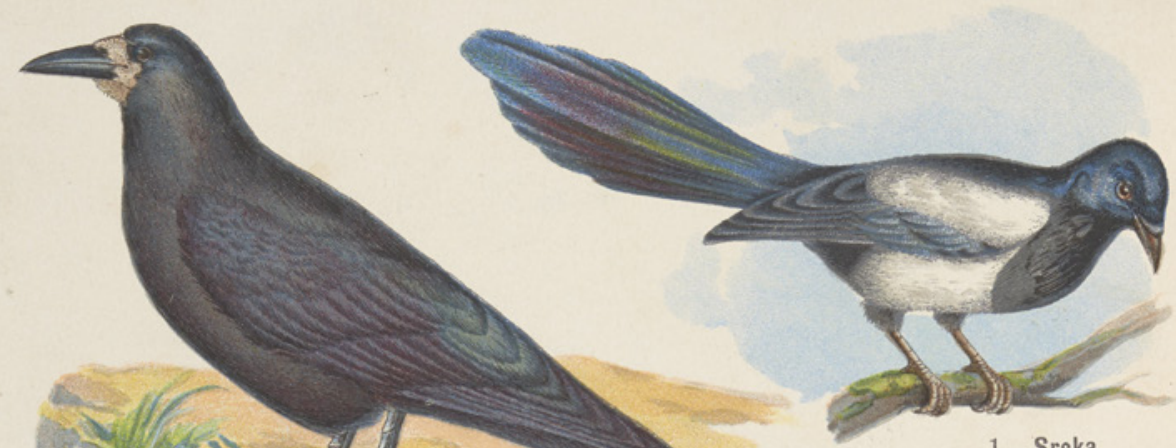

1. Sroka.

Pica caudata.
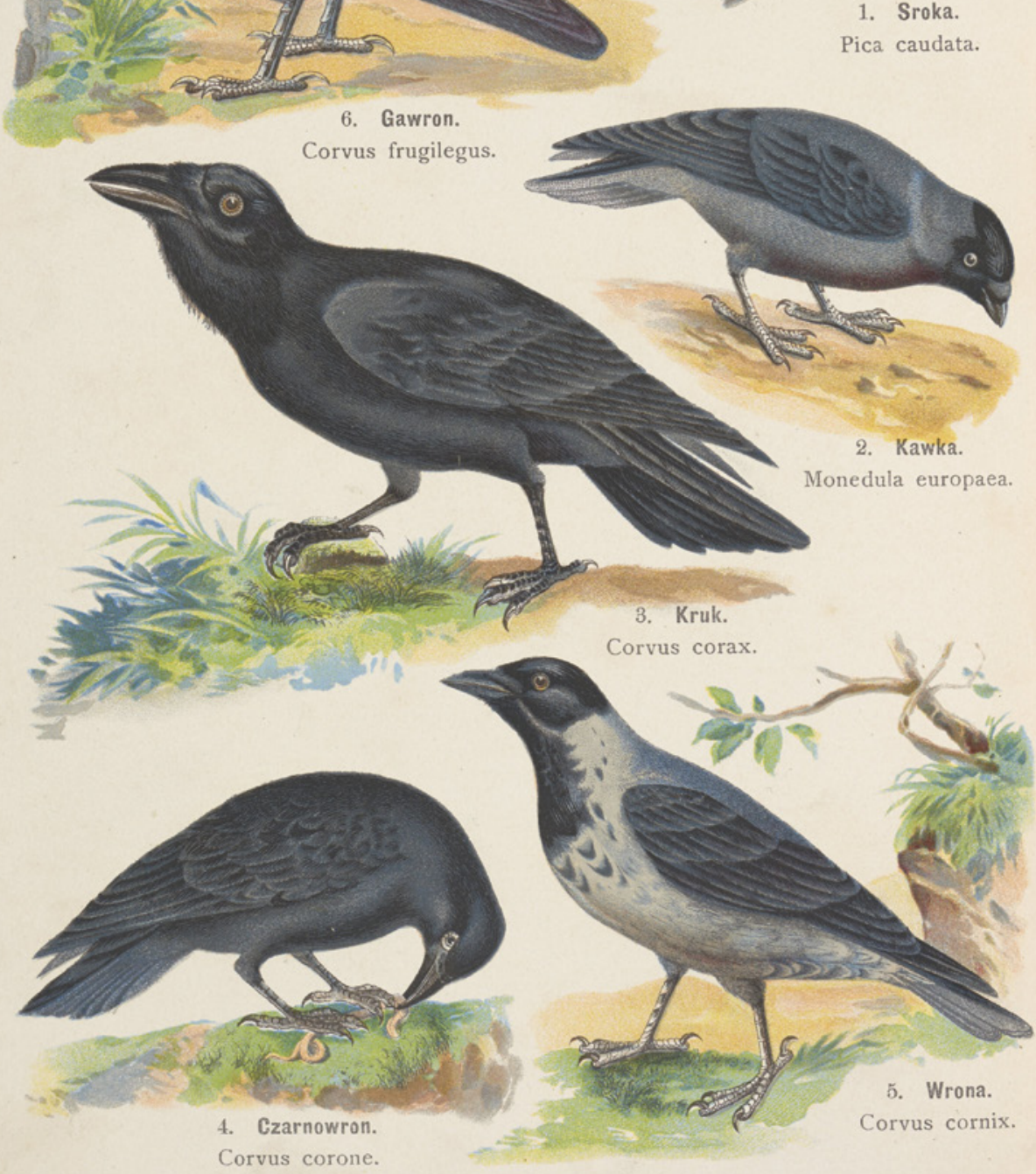

Kurt Lampert, Atlas państwa zwierzęcego, cz. 2, Ptaki, Warszawa 1905, s. 12 ŻRÓDŁO: BBBLIOTEKA NARODOWA W WARSZAWIE, DOMENA PUBLICZNA 
przez dyskursywne przemiany ostatnich dwóch stuleci. Dodały one kilka nowych cech do osadzonego mocno w kulturowej tradycji obrazu gawrona, który od samego początku sytuował się na granicy różnych kategorii służących do porządkowania świata natury.

Na specyfikę tego wizerunku wpłynęła rodzinna reputacja. Gawron wywodzi się przecież z rodziny krukowatych, która w kulturze minionych stuleci podejrzewana była o konszachty ze sferą nadprzyrodzoną. Ptakom tym przypisywano możliwość kontaktu z zaświatami, umiejętność przepowiadania przyszłości, nieprzeciętną mądrość, a jednocześnie uznawano je za „złowróżebne, żałobne, wieszczące nieszczęście, choroby, zarazy wojny i śmierć"2. Od najdawniejszych czasów niechęć budził zwłaszcza ich zwyczaj żerowania na zwłokach i padlinie. Znamienne jednak, że wszystkie te właściwości przypisywane były w pierwszym rzędzie krukom oraz wronom, co wyraźnie zresztą widać również w literaturze polskiej, na przykład w znanym opowiadaniu Żeromskiego Rozdziobią nas kruki, wrony. O wiele częściej w negatywnym kontekście pojawiają się zwłaszcza te pierwsze, obsadzane w negatywnych rolach u Adama Mickiewicza, Wincentego Pola i wielu innych autorów ${ }^{3}$. Co znamienne, w utrzymanych w kręgu takiej poetyki i stylistyki obrazach często brakuje gawronów, które nie pasowały do tego rodzaju rodzinnych portretów.

Ślady tego outsiderstwa rozsiane są po polszczyźnie. Jak przekonują językoznawcy, przedrostek „ga-" w słowie „gawron” miał funkcję umniejszającą i oznaczał coś gorszego od wrony Zresztą już w XVI wieku porównanie do gawrona uchodziło za obelgę nie tyle ze względu na sugerowany związek z siłami nieczystymi, ile z powodu panującego dość powszechnie przekonania o niewielkiej inteligencji tych ptaków, na co prawdopodobnie wpłynął tyleż ich wygląd, co i sposób poruszania się na ziemi. Mikołaj Rej w Wizerunku (Sokrates) do gawrona porównywał osobę „pozbawioną rozumu”, natomiast w stanowiącym część Zwierciadła tekście O przyszłych rzeczach nikt nie myśli określał osoby cechujące się tytułową skłonnością mianem „młodych gawronów, które czekają gębę rozdziawiwszy, aż jej w nią czo wetkają" 0 tym, że nie była to wyjątkowa cecha Rejowego języka, przekonują również późniejsze słowniki, na przykład Aleksander Brückner odnotowuje odrzeczownikowy czasownik „gawronić się” oznaczający tyle, co „bezmyślnie patrzeć”, dodając z przekąsem, że „Mazurom i Litwinom ten ich specjał często wypominają od XVII wieku”. W kolejnych stuleciach znaczenie słowa „gawron” przechowało ten negatywny odcień, który był bardzo żywotny jeszcze na początku XX stulecia - w Słowniku Karłowicza, Kryńskiego i Niedźwiedzkiego stosowne hasło informuje, że jest to określenie odnoszące się nie tylko do ptaka, lecz także do „głuptasa, cymbała, gamonia, bałwana, jełopa, tępej głowy, głupca”, który „wytrzeszcza oczy na byle co”, „rozziewia lub rozdziawia gębę”, jak również do osoby nierozważnej i łatwowiernej ${ }^{8}$. To ostatnie znaczenie było dość żywotne w międzywojennej prasie kryminalnej oraz satyrycznej, gdzie „łapaniem gawrona” określano proceder polegający na naciąganiu i oszukiwaniu przypadkowej ofiary, która najczęściej wywodziła się z prowincji.

Gawron dość szybko roztrwonił rodzinną reputację, najpóźniej w XVI stuleciu został relegowany z grupy ptaków podejrzanych o konszachty z siłami nieczystymi do klasy stworzeń nieszkodliwych. Najpewniej zaważyły na tym pospołu wspomniane już wcześniej wygląd i sposób bycia, które w połączeniu ze względnie małą płochliwością stwarzały ludziom mnóstwo okazji do naocznego przekonania się, że pozornie złowrogi czarny ptak przy bliższym oglądzie traci swoją demoniczną aurę. Trudno przecież wyobrazić sobie emisariusza Księcia Ciemności niezgrabnie człapiącego po polu w poszukiwaniu pożywienia.

Być może z tego względu o gawronach już w XVI wieku pisano z mieszanką pobłażliwości i irytacji, jak choćby w książce Mateusza Cygańskiego Myślistwo ptasze, w którym się opisuje sposób dostawania wszelakiego ptaka. W tej pracy, długo uznawanej za zaginioną i odnalezionej dopiero w XIX wieku, autor zawarł porady łowieckie związane ze sposobami chwytania różnych gatunków ptaków. Jednocześnie zaś scharakteryzował każdy z nich w krótkich wierszykach, które z dzisiejszej perspektywy stanowią cenny dokument stanu ówczesnej wiedzy przyrodniczej. W przypadku gawrona napisany mową wiązaną tekst brzmiał: „Polny ptak Gawron y częśćią domowy/ Przy polach możny a głos puszcza basowy/ Na niepogodę co nabardziey śpiewa/ Aż się wrzaskiem swem ludziom uprzykrzywa".

Życie gawronów w sąsiedztwie ludzkich siedzib oraz czyniony przez nie nieustanny hałas to cechy, które podkreślali kolejni badacze natury, na przykład w XVII wieku Gabriel Rzączyński pisał, że ptaki te „trzymają się stadami koło wsi i miast” ${ }^{10}$. Podobną informację można odnaleźć w opublikowanej w drugiej połowie kolejnego stulecia książce Jana Krzysztofa Kluka o pełnym 
rozmachu tytule Zwierzqt domowych i dzikich, osobliwie krajowych, historii naturalnej początki i gospodarstwo. Potrzebnych i pożytecznych domowych chowanie, rozmnożenie, chorób leczenie, dzikich łowienie, oswojenie, zażycie, szkodliwych zaś wygubienie. Pisał tam, że gawron „gnieździ się i wylęga jak wrona na drzewach, w lasach nad wodami, łąkami, a czasem i pojedynczo gdzie stojących. Tak się trzymają wspólnego towarzystwa, że się jedna para na gnieździe gnieździć nie będzie, lecz tak wiele razem, iż gniazd pełno narobią"11. Natomiast w opublikowanej dekadę później Zoologii krótko zebranej autorstwa Stanisława Jundziłła jest mowa o tym, że gawrony „puszcz głuchych i lasów wielkich unikają, owszem blisko pól, wsi i miasteczek mieszkanie swe zakładają, a całą okolicę wrzawą bezustannie napełniają"12.

Hałas był dokuczliwy, lecz nie wpływał w namacalny sposób na księgi rachunkowe. Sen z oczu właścicieli ziemskich spędzało natomiast podejrzenie, że za tym uciążliwym sposobem bycia kryje się zagrażający ich dochodom sposób żerowania polegający na masowym wyjadaniu wysianych na polach lub przechowywanych podczas zimy ziaren. Z tego względu ptaki te były często tępione, do czego zresztą zachęcały rozsiane po literaturze przedmiotu sugestie. Na przykład cytowany już wcześniej Kluk pisał, że gawron „trzyma pospolicie towarzystwo z kawkami, a czasem i z wronami. Nie jest tak łakomy na ścierw, lecz bardziej na ziarna”"13. Zupełnie inaczej na tę sprawę zapatrywał się Jundziłł:

Mniemaniem jest powszechnym, że gawrony ziarnem się karmią, a mianowicie świeżo posianem na polu żytem i pszenicą, skąd i imię im frugilegus jest nadane. Dziś, z niewątpliwych postrzeżeń i z często powtarzanego rozbierania i otwierania żołądka świeżo zabitych gawronów, niewątpliwie jest wiadomo, iż pokarm ich jest całkowicie zwierzęcy [...]. Ptaki te więc nie tylko nie są bynajmniej szkodliwe zasiewom naszym, owszem, zjadając mnóstwo żarłocznych owadów i zwierząt, rzetelną w polach rolnikom czynią posługę. W czasie pustoszenia liczby szarańczy gawrony do zmniejszenia jej liczby najdzielniej się przykładają ${ }^{14}$.

Obserwacje takie prowadziły do stopniowej rehabilitacji gawrona. Obrana przez kolejnych badaczy linia obrony była w każdym przypadku podobna, na przykład Antoni Waga w Atlasie historyi naturalnej (1860) pisał, że gawrony likwidują pędraki na polach rolników, dlatego nie należy tych ptaków zabijać, ponieważ one są „dzielnymi pomocnikami człowieka w oczyszczaniu roli"15. Kilka lat potem analogiczne argumenty powtórzył Albin Kahn w wydanej nakładem serii Biblioteczka dla Polskiego Rolnika (t. 1) książce O potrzebie ochraniania użytecznych zwierzq̨t (1866). Charakterystykę wspomnianych w tytule gatunków poprzedził krótkim wprowadzeniem ujawniającym ramę dyskursywną, wewnątrz jakiej osadzone były poglądy autora, charakterystyczne dla tej części ówczesnych nauk przyrodniczych, która postrzegała obiekt swoich badań w horyzoncie metafizycznym:

Odkąd anatomia zaczęła zajmować się zwierzętami i badano ich sposób żywienia się, coraz jaśniejsze pojęcia upowszechniać się zaczynają i coraz to więcej głosów odzywa się za ochroną zwierząt mięsożernych i owadożernych, w których uznajemy zbawienną policję natury, którą Pan Bóg w swej nieograniczonej mądrości ustanowił dla ograniczenia niezmiernej liczby zwierząt roślinożernych, które pracom rolnika zagrażają ${ }^{16}$.

Dzięki badaniom ornitologów na przełomie XIX i XX stulecia gawron przestał być traktowany jako zagrażający uprawom rolnikom szkodnik, lecz nie oznaczało to bynajmniej, że przestał sprawiać problemy człowiekowi.

Wraz z nastaniem nowoczesności pojawiała się nowa kategoria zwierząt „kłopotliwych”. Zrazu mało widoczna, nabierała coraz wyraźniejszego kształtu z wraz postępowaniem procesów urbanistycznych, które wytwarzały nie tylko zupełnie nowe typy aglomeracji, lecz także a może nawet przede wszystkim - wiązkę zasad regulujących funkcjonowanie tychże. Procesy standaryzacji, puryfikacji oraz upowszechniania idei higienicznych w znamienny sposób przetasowały relację między człowiekiem a zwierzętami. (Jednocześnie wszystkie praktyki, za 
sprawą których przekonana o własnej wyjątkowości epoka tworzyła warunki dla dalszego coraz intensywniejszego wzrostu, w sporym stopniu związane były z obecnością zwierząt w miastach, na przykład konia) ${ }^{17}$. Konsekwencją takiego stanu rzeczy stało się wytworzenie sterylnej, podporządkowanej idei ładu przestrzeni, z której starano się wyeliminować zwłaszcza te spośród zwierząt synantropijnych, które uznano za niebezpieczne dla populacji ze względu na ryzyko roznoszenia chorób. Znamienne jednak, że w przypadku gawrona zagrożenie nie było tak znaczne, bo przecież ograniczało się wyłącznie do krótkiego czasu i niewielkiej przestrzeni (tj. parków w okresie lęgowym). Pomimo to im bliżej minionego stulecia, tym częściej pisano o tym ptaku jako o miejskim intruzie, naruszającym porządek oraz ustalone przez ludzi zasady, a także stanowiącym zagrożenie dla pielęgnowanej przez nowoczesne dyskursy idei czystości i higieny.

Wynikało to $\mathrm{z}$ faktu, że mniej więcej w tym czasie zmieniał się zasięg występowania gatunku. Trudno dziś jednoznacznie określić, kiedy zaczął się proces gniazdowania w miastach, zwłaszcza że autorzy dawnych książek ornitologicznych piszą raczej o gawronach jako o ptakach rzadko tam przebywających. Na przy-

Na specyfikę tego wizerunku wpłynęła rodzinna reputacja. Gawron wywodzi się przecież z rodziny krukowatych, która w kulturze minionych stuleci podejrzewana była o konszachty ze sfera nadprzyrodzoną.

kład Samuel Merzbach w połowie wieku XIX pisał, że „jak inne kruki, zimą odwiedza kupy gnoju w bliskości miast i wsi, a nawet częstokroć siada na ulicach, wszakże tylko, gdy mu mocno głód dokucza"18, natomiast inni autorzy - Jundziłł ${ }^{19}$, Paweł Leśniewski ${ }^{20}$ i Władysław Taczanowski - stwierdzali, że na znanych im terenach gawrony lęgną się bardzo rzadko. Ten ostatni w Ptakach krajowych (1882) pisał: „W Królestwie Polskim nie znam żadnego miejsca, gdzie by się stale gnieździły, jak w innych sąsiednich krajach, gdzie mają już od dawna uprzywilejowane gaje, w których się ciągle w wielkim mnóstwie wywodzą"21, a jednocześnie odnotował być może jedną z pierwszych informacji na temat przepłaszania ich z miast:

[...] kilkanaście lat temu miały swoje gniazda w ogrodzie Saskim w Warszawie, lecz gdy drzewa ich wycięto, wyniosły się zupełnie. Przez kilka lat ostatnich kilkadziesiąt par gnieździło się w ogrodzie wilanowskim po starych topolach nadwiślańskich; podobnie w gaiku pod Czernicami o dwie mile od Przasnysza. Z wiosny w początku kwietnia kilkadziesiąt par nagle przyleciało do małego gaju olszowego pod Bielawą o dwie mile od Warszawy i natychmiast zaczęły słać gniazda. Wszystkie już prawie siedziały na jajach, które im częścią pozabierano, a od innych odstraszono ${ }^{22}$.

W kolejnych dekadach tego rodzaju sytuacje zdarzały się często, o czym świadczą rozsiane po prasie wzmianki. W 1909 roku na łamach „Przyjaciela Zwierząt” (prasowego organu warszawskiego Towarzystwa Opieki nad Zwierzętami) w korespondencji z Krakowa pisano: „[...] wielką wrzawę wywołała u nas sprawa gawronów, gnieżdżących się na drzewach plant przed Collegium Novum, zarząd plant niszczy corocznie ich gniazda celem rzekomej ochrony ptactwa śpiewającego przed żarłocznością gawronów”. A zaraz potem wspominano o sporze, jaki wywołała ta sytuacja: „Artykułom dziennikarskim, dopowiedziom i sprostowaniom nie było końca, stworzyły się dwa obozy, nieprzyjaciół i obrońców gawronów, walczące ze sobą zawzięcie”23. Dyskusje te były zarówno świadectwem coraz bardziej skoordynowanych działań obrońców zwierząt, jak i dowodem na to, że w tego rodzaju konfliktach rzetelna wiedza naukowa schodziła na plan dalszy, przyćmiona przez nierzetelne argumenty uzasadniające praktyki władz miejskich. 
W kolejnych dekadach sytuacja nie uległa większej zmianie, o czym świadczą doniesienia prasowe. Warto tutaj przytoczyć niektóre z nich in extenso, bo wyraźnie ujawniają napięcie, jakie wyznaczało ramy dyskusji na temat sposobu traktowania nie tylko gawronów, lecz także innych zwierząt żyjących w sąsiedztwie człowieka.

W opublikowanej na łamach „Ziemi Lubelskiej” 11 kwietnia 1921 roku notatce Hodowla wron i gawronów w Ogrodzie Miejskim anonimowy autor w strofującym tonie pisał o wiosennym nieporządku związanym z okresem lęgowym:

Zarząd Ogrodu Miejskiego [...] pozwolił wronom i gawronom na uwicie setek gniazd na drzewach Ogrodu Miejskiego, czego skutek będzie przede wszystkim taki, że wyniesie się stąd wszystkie śpiewające ptactwo, a natomiast będziemy wciąż słyszeć wrzaskliwe, potępieńcze krakanie czarnego ptactwa. Hodowla takich wron i gawronów nieznana w ogrodach publicznych większych miast europejskich tym bardziej natychmiast powinna być wytępioną, że ptactwo to zanieczyszcza ławki i ubrania przechadzającej się publiczności ${ }^{24}$.

Wezwanie to nie pozostało bez echa, bo wkrótce potem gazeta z satysfakcją donosiła o usunięciu gniazd niepożądanych gości, co w mniemaniu autora miało być krokiem zbliżającym Lublin w stronę cywilizowanych miast kontynentu.

Gawron zupełnie nieświadomie stał się wyzwaniem dla nowoczesnej idei higieny. Zasadzała się ona na segregowaniu oraz separowaniu od siebie bytów, wyznaczaniu wciąż uszczelnianych granic pomiędzy tym, co ludzkie i pozaludzkie, oraz rzeczywistym (i metafizycznym) wprawianiu w ruch procesów oczyszczania i sterylizacji. Idee, jakie w znacznej mierze przesądziły o sukcesie nowoczesności, wytworzyły też wiele praktyk, które zorganizowały świat według nowych zasad, stawiając wyraźną barierę pomiędzy kulturą a naturą. Przełożyło się to na nowy słownik epoki, w którym świat zwierzęcy zaczęto określać za pomocą haseł odnoszących się nie tylko do zagrożenia, lecz także zanieczyszczenia. Hałaśliwy, nieporadny, wszędobylski i rzucający się w oczy ptak nie pasował do higienicznych standardów, a jego nieproszona obecność w parkach urastała do rangi złośliwego wyzwania rzuconego zarówno pragnącym porządku miejskim obywatelom, jak i nieustannie doskonalącej swoją czystość epoce. O ile bowiem w poprzednich epokach kolonie gawrona były plądrowane przede wszystkim dlatego, że wykradano z nich jaja i pisklęta (które notabene uznawano za przysmak)25, oraz ze względu na to, że ptaki te uznawano za szkodniki, o tyle od końca XIX stulecia motywacje „kulinarne” zostały zastąpione powodami higieniczno-estetycznymi. W latach międzywojennych niszczenie gawronich kolonii w miastach było praktyką dość powszechną, a jednocześnie coraz częściej piętnowaną na łamach prasy. Publicyści domagali się często nie tylko ukarania sprawców, lecz także uregulowania przepisów dotyczących ochrony zwierząt w miastach. Za przykład takiego stanowiska może posłużyć artykuł opublikowany 3 czerwca 1927 roku na łamach wileńskiego „Słowa”:

Przed kilku dniami byliśmy świadkami okropnej sceny. Jakiś człowiek łaził po drzewach ogrodzonej parkanem posesji przy ulicy Witoldowej 6, zrzucając gniazda gawronie wraz z małymi pisklętami, mordując je niemiłosiernie, tłukąc o ziemię itd. Krzyk ptaków zabijanych i żałośne krakanie starych gawronów mieszały się ze złorzeczeniami pod adresem tego kata ptasiego, zebranej, oburzonej publiczności.

Bezwzględnie należy raz z tym skończyć. W sprawę tę wglądnąć winien Komisariat Rządu i władze policyjne. Gawrony uznane są przez najwybitniejszych ornitologów za ptaki bezwzględnie pożyteczne. Jako takie też ochraniane są wszędzie, a w tym względzie Ministerstwo Rolnictwa i Dóbr Państwowych roztacza nad nimi swoją opiekę. Powinny więc czynniki kompetentne pouczyć nasze władze administracyjne, w jaki sposób ukrócić tępienie tych pożytecznych ptaków ${ }^{26}$. 
Apel ten zbiegł się w czasie z pracami nad Rozporzq̨dzeniem o prawie łowieckim, które weszło w życie 3 grudnia $1927 \mathrm{roku}^{27}$. Zawarte w nim postanowienia pozwoliły gawronowi uniknąć losu wielu bezwzględnie tępionych wówczas gatunków, bo ptaki krukowate zostały zaliczone do zwierząt łownych i objęto je okresem ochronnym, obowiązującym od 1 lutego do 15 sierpnia (art. 49). Jednak nie dotyczyło to wszystkich krukowatych, bo na mocy tegoż rozporządzenia można było bez przeszkód polować na sroki i wrony oraz podbierać ich jaja, wybierać pisklęta i niszczyć gniazda (art. 50). Powojenne władze spojrzały na gawrony łaskawszym okiem. W Dekrecie z 29 października 1952 r. o prawie łowieckim wykaz „zwierzyny łownej”, wyraźnie wzorowany na międzywojennym, uszczuplony został o „ptaki krukowate”28, natomiast w Rozporzq̨dzeniu Ministra Leśnictwa z 4 listopada 1952 roku umieszczono gawrona (i kawkę, a rok później także kruka) na liście ptaków chronionych ${ }^{29}$. Przychylność władz nie trwała jednak zbyt długo, bo taki stan rzeczy utrzymywał się zaledwie niecałe trzy lata. Na mocy Rozporzq̨dzenia Ministra Leśnictwa z 9 marca 1955 roku ${ }^{30}$ oba te ptaki zostały z tejże listy wykreślone. Można się domyślać, że uznano je za szczególnie kłopotliwe, ponieważ wspomniany akt został uchwalony jedynie w tym celu i nie wprowadzał żadnych innych zmian w wykazie zwierząt łownych. W kolejnych dekadach sytuacja nie uległa zmianie. W Rozporządzeniu z 30 grudnia 1983 roku ${ }^{31}$ gawron wraz ze sroką i wroną znów znalazł się poza listą ptaków chronionych (co ciekawe, półrocznym okresem ochronnym objęto kawkę). Sytuację zmieniło dopiero Rozporzq̨dzenie Ministra Ochrony Środowiska, Zasobów Naturalnych i Leśnictwa z 6 stycznia 1995 roku, na którego mocy gawronowi wraz ze sroką i wroną siwą przyznano okres ochronny, zresztą - na co warto zwrócić uwagę - aż o trzy miesiące krótszy niż w rozporządzeniu o prawie łowieckim z międzywojnia (bo zamykający się w okresie między 15 marca a 30 czerwca) $)^{32}$. W kolejnych latach sytuacja zmieniała się coraz szybciej. Na mocy aktu z 26 września 2001 roku ścisłą ochroną objęto wszystkie krukowate, z wyjątkiem wrony siwej oraz sroki (ochrona częściowa) ${ }^{33}$, ale już trzy lata później na mocy rozporządzenia z 28 września 2004 roku gawron wraz ze sroką, krukiem, wroną siwą (lecz nie kawką!) został wyjęty spod ochrony całkowitej i zapewniono mu jedynie częściową ${ }^{34}$, stan ten zaś utrzymało późniejsze o niemal dekadę rozporządzenie z 12 października 2011 roku (notabene tylko częściową ochroną w tym akcie została objęta wrona siwa) ${ }^{35}$. Wreszcie w rozporządzeniach z 6 października $2014^{36}$ oraz 28 grudnia 2016 roku $^{37}$ gawrona objęto ochroną całkowitą ze wspomnianą na początku niniejszego szkicu adnotacją - „osobniki poza obszarem administracyjnym miast”, natomiast częściową - „osobniki w obszarze administracyjnym miast”.

Formuła ta przypieczętowała kłopotliwy status gawrona, który od samego początku nie do końca mieścił się w siatce pojęć służących do porządkowania świata natury. Porządek symboliczny łączył go ze sferą nadprzyrodzoną, podczas gdy bliższe praktyce doświadczenie utrwalone w języku zaliczało w poczet zwierząt niegroźnych i pozbawionych inteligencji. W dawnym myślistwie, z którego w przyszłości wyłonić się miały zręby przyrodoznawstwa, nie uznawano go za ptaka łownego, lecz mimo wszystko był on często zabijany, jego mięso, choć pozbawione walorów smakowych, często stawało się pokarmem ubogich. Z kolei w wieku XIX uznawano go zarazem za szkodnika i za „policjanta natury”, a tego dwuznacznego obrazu nie potrafiła skutecznie zatrzeć rodzima ornitologia oraz ówcześni miłośnicy przyrody, bo ptaki z tego gatunku wciąż były zabijane. Dwudziestowieczne prawo raz było jego sprzymierzeńcem, raz z kolei wrogiem, wraz z kolejnymi rozporządzeniami przesuwano z kategorii zasługującej na pełną bądź częściową ochronę do grupy zwierząt pozbawionych takowej.

Pomimo to w ostatnich dekadach zrobiono wiele, jeśli chodzi o uporządkowanie współżycia między człowiekiem a gawronem: najczęściej ptaków już się nie zabija, lecz płoszone są za pomocą wytresowanych ptaków drapieżnych, drzewa zabezpieczane są przed lęgami, lecz i tak wciąż jesteśmy dalecy od trwałego rozwiązania problemów, jakie wynikają z tego sąsiedztwa ${ }^{38}$. W dyskursie medialnym co roku powracają mrożące krew w żyłach nagłówki, w których gawrony i inne krukowate oskarża się o umyślną złośliwość względem ludzi, swoje trzy grosze dodają też myśliwi, którzy obwołują się samozwańczymi strażnikami higieny i porządku. Towarzyszy temu metaforyka, która zasługuje na analizę analogiczną do tej, jaką swojego czasu przeprowadził w odniesieniu do gołębia miejskiego Colin Jerolmack w artykule pod wiele mówiącym tytułem How Pigeons Became Rats, gdzie analizuje oparte na stereotypowych wyobrażeniach praktyki językowe, z których wyłania się wyobrażenie gołębia jako skrzydlatego szczura ${ }^{39}$. 
Warto podkreślić, że w przypadku gawrona podobna metaforyka tworzy niezamierzony dysonans pomiędzy krzywdzącym stereotypem a ostatnimi badaniami naukowymi, które dowodzą, że jest to jeden z najbardziej inteligentnych ptaków świata. Tak sugerują między innymi badania Nathana Emery’ego, który opisał sposób, w jaki gawrony posługują się narzędziami i jak produkują je przy użyciu tak zwanych metanarzędzi. W przetłumaczonej niedawno książce Ptasia inteligencja: rozważania nad intelektem ptaków dowodził, że krukowate mają zdolności poznawcze, które zbliżają je do najinteligentniejszych zwierząt na Ziemi - szympansów, delfinów i słoni ${ }^{40}$. O tym, jak bogate jest nie tylko życie intelektualne, lecz także społeczne gawronów, przekonuje również książka Corvus, życie wśród ptaków, której autorka, Esther Woolfson, opisuje swoje doświadczenia zebrane podczas opieki nad udomowionym krukiem ${ }^{41}$. W świetle tych ustaleń trudno więc powiedzieć, skąd ta dość powszechna niechęć człowieka do gawrona; czy czasem nie wynika ona stąd, że na Ziemi istnieje jeszcze jeden gatunek, który - podobnie jak on jest hałaśliwy, zakłada wspólne osady i zanieczyszcza ich otoczenie, przemieszcza się oraz szuka pożywienia w grupach, poruszając się w skoordynowany i zaplanowany sposób, a jednocześnie potrafi zwodzić, okradać i oszukiwać pobratymców?

\section{PRZYPISY}

1 Rozporzadzenie Ministra Środowiska z dnia 16 grudnia 2016 r. w sprawie ochrony gatunkowej zwierzą, http://prawo.sejm.gov.pl/isap.nsf/DocDetails.xsp?id=WDU20160002183 (dostęp: 7.12.2018).

2 P. Indykiewicz, Gawron Corvus frugilegus... i inne krukowate, Bydgoszcz 2007, s. 11. Autorzy książki In the Company of Crows and Ravens w rozważaniach na temat krukowatych piszą wręcz, że "nie znają innego zwierzęcia, które w trwały i gruntowny sposób wpłynęły na sztukę, język, religię (i naukę) już od zarania ludzkości". Zob. J. Marzluff, T. Angell, In the Company of Crows and Ravens, London 2005, s. 151.

3 P. Indykiewicz, Gawron Corvus..., dz. cyt., s. 11-13.

4 Zob. K. Kłosińska, Skąd się biorą słowa, Warszawa 2005, s. 189

5 M. Rej, Sokrates, w: tenże, Pisma wierszem (wybór), oprac. J. Krzyżanowski, Wrocław 1954, s. 186.

6 M. Rej, O przyszłych rzeczach nikt nie myśli, w: tenże, Żywot człowieka poczciwego, oprac. J. Krzyżanowski, Wrocław 1956, s. 505.

7 A. Brückner, Słownik etymologiczny języka polskiego, t. 1, Kraków 1927, s. 137.

8 W. Niedźwiedzki, A. Kryński, J. Karłowicz (red.), Słownik języka polskiego, t. 1, Warszawa 1900, s. 810.

9 M. Cygański, Myślistwo ptasze, dzieło z XVI. wieku, obejmujace wykład wszystkiego, co wówczas do ptasznictwa w Polszcze należało, a obok tego wymieniajace rodzaje i gatunki ptaków krajowych: teraz na nowo przedrukowane z dodaniem przedmowy, objaśnień i przypisów Antoniego Wagi, Warszawa 1842, s. 71. W najstarszych polskich pracach poświęconych łowiectwu przewija się informacja, że myśliwi nie zabijali gawronów dla mięsa. Zarówno Cygański, jak i Tomasz Bielawski w Myśliwcu (1595) piszą, iż jedyny pożytek z zabicia tych ptaków mogą mieć organiści, używający piór tychże do wyrobu instrumentów.

10 Z. Fedorowicz, Fauna Polski w dziełach o. Gabriela Rzaczyńskiego T. J. (1664-1737), Warszawa 1966, s. 173

11 J.K. Kluk, Zwierzą domowych i dzikich, osobliwie krajowych, historii naturalnej początki i gospodarstwo. Potrzebnych i pożytecznych domowych chowanie, rozmnożenie, chorób leczenie, dzikich łowienie, oswojenie, zażycie, szkodliwych zaś wygubienie, t. 2: O ptastwie, Warszawa 1797, s. 288.

12 S.B. Jundziłt, Zoologia krótko zebrana, cz. 2: Ptastwo, Wilno 1807, s. 74.

13 J.K. Kluk, Zwierząt domowych..., dz. cyt., s. 288.

14 S.B. Jundziłł, Zoologia krótko zebrana, dz. cyt., s. 75.

15 A. Waga, Atlas historyi naturalnej z 222 kolorowanemi wizerunkami i ze szczegółowym tekstem do każdego wizerunku z polsko-łacińsko-francusko-niemiecką nomenklaturą przedmiotów, Warszawa 1960, s. 101

16 A. Kahn, O potrzebie ochraniania użytecznych zwierząt, Warszawa 1862, s. 5-6. Trzeba dodać, że - czego zresztą nie ukrywał autor - pewien wpływ na powstanie tej książki miała praca niemieckiego uczonego Constantina Glogera, opublikowana w języku polskim pod tytułem Wytępienie robactwa i myszy pustoszacych gospodarstwo leśne i polne. Stanisław Szenic, autor spolszczenia, bo trudno w tym wypadku mówić o dosłownym przekładzie, w przedmowie ujawnił ciekawe kulisy publikacji: niemiecki uczony przesłał swoją pracę z propozycją przetłumaczenia jej na język polski do poznańskiego Towarzystwa Przyjaciół Nauk, które orzekło, że może to zrobić pod warunkiem uzupełnienia książki o informacje dotyczące rodzimych gatunków zwierząt i sposobów, w jaki można zapobiec czynionym przez nie spustoszeniom w gospodarstwach. Dzięki temu partie poświęcone gawronom zostały znacznie rozbudowane; niemiecki badacz w swoich wywodach zdecydowanie potępiał barbarzyńskie traktowanie tych ptaków przez ludz niszczących gniazda i zabijających pisklęta, dowodząc, że gawrony w znaczny sposób przyczyniają się do zwalczania zagrażających rolnictwu szkodników, natomiast tłumacz we fragmentach poświęconych 
różnym regionom kraju dodawał, że „nie ma żadnego ptaka, który by zwłaszcza wytępianiem chrząszczy i ich poczwarek wiekssza wyrządzał przysługe jak gawron. Na Podolu, Wołyniu, jako też na Litwie zimuje on wraz z wronami. Ogromne ich stada napadają wprawdzie na sterty zboża i czynią w nich szkodę; ale też znowu, gdy się zdarzy szarańcza, one idą za jej chmurą z kawkami i wronami i bardzo wiele szarańczy wyjadają". C. Gloger, Wytępienie robactwa i myszy pustoszacych gospodarstwo leśne i polne, przeł. i oprac. S. Szenic, Poznań 1860, s. 38

17 Zob. P. Atkins, The Urban Blood and Guts Economy, w: tenże (red.), Animal Cities. Beastly Urban Histories, Farnham 2012. Fragmenty tej pracy w polskim tłumaczeniu w tym tomie, zob. Zwierzęce nieczystości i utrapienia w dziewiętnastowiecznym Londynie, przeł. J. Schollenberger

18 S. Merzbach, Księga Świata: wiadomości z dziedziny nauk przyrodzonych, historyi krajów i ludów, żywoty znakomitych ludzi, podróże, opisy ciekawych miejscowości, wód słynniejszych, odkrycia i wynalazki, ważniejsze zajęcia przemysłowe, obrazy towarzyskie, statystyczne, ekonomiczne itp., cz. 1, Warszawa 1852, s. 216

19 S.B. Jundziłł, Zoologia krótko zebrana, dz. cyt.

20 P.E. Leśniewski, Historya naturalna: systematycznie ułożona podług Milne-Edwardsa, Reichenbachra, Gistla, Richarda, Bromma i wielu innych znakomitych zagranicznych i krajowych naturalistów, Warszawa 1843.

21 W. Taczanowski, Ptaki krajowe, t. 1, Kraków 1882, s. 384

22 Tamże.

23 [Anonim], Listy z Krakowa, „Przyjaciel Zwierząt” 1909, nr 7

24 [Anonim], Hodowla wron i gawronów w ogrodzie miejskim, „Ziemia Lubelska” 1921, nr 11, s. 2.

25 W Ornitologii powszechnej (1843-1846) Konstantego Tyzenhauza znajduje się wzmianka, że wyjęte z gniazda młode gawrony były uważane za przysmak.

26 [Anonim], Jeszcze o rzezi na Zwierzyńcu, "Słowo" 1927, nr 125, s. 4

27 Rozporzadzenie Prezydenta Rzeczypospolitej z dnia 3 grudnia 1927 r. o prawie łowieckiem, http://prawo. sejm.gov.pl/isap.nsf/download.xsp/WDU19271100934/O/D19270934.pdf (dostęp: 7.12.2018).

28 Dekret z dnia 29 października 1952 r. o prawie łowieckim, http://prawo.sejm.gov.pl/isap.nsf/download. xsp/WDU19520440300/O/D19520300.pdf (dostęp: 7.12.2018).

29 Rozporządzenie Ministra Leśnictwa z dnia 4 listopada 1952 r. w sprawie wprowadzenia gatunkowej ochrony zwierzat, http://prawo.sejm.gov.pl/isap.nsf/download.xsp/WDU19520450307/O/D19520307.pdf (dostęp: 7.12.2018).

30 Rozporzadzenie Ministra Leśnictwa z 9 marca 1955 r. zmieniajace rozporzadzenie z dnia 4 listopada 1952 r. w sprawie wprowadzenia gatunkowej ochrony zwierzat, http://prawo.sejm.gov.pl/isap.nsf/download.xsp/ WDU19550170103/O/D19550103.pdf (dostęp: 7.12.2018).

31 Rozporzadzenie Ministra Leśnictwa i Przemysłu Drzewnego z dnia 30 grudnia 1983 r.w sprawie wprowadzenia gatunkowej ochrony zwierzat, http://prawo.sejm.gov.pl/isap.nsf/download.xsp/WDU19840020011/O/ D19840011.pdf (dostęp: 7.12.2018)

32 Rozporzadzenie Ministra Ochrony Środowiska, Zasobów Naturalnych i Leśnictwa z 6 stycznia 1995 r. w sprawie ochrony gatunkowej zwierząt, http://prawo.sejm.gov.pl/isap.nsf/download.xsp/WDU19950130061/O/ D19950061.pdf (dostęp: 7.12.2018)

33 Rozporzadzenie Ministra Środowiska z dnia 26 września 2001 r. w sprawie określenia listy gatunków zwierzat rodzimych dziko występujących objętych ochrona gatunkową ścisła i częściowa oraz zakazów dla danych gatunków i odstępstw od tych zakazów, http://prawo.sejm.gov.pl/isap.nsf/download.xsp/WDU20011301456/O/ D20011456.pdf (dostep: 7.12.2018).

34 Rozporzadzenie Ministra Środowiska z dnia 28 września 2004 r. w sprawie gatunków dziko występujących zwierzat objętych ochrona, http://prawo.sejm.gov.pl/isap.nsf/download.xsp/WDU20042202237/O/ D20042237.pdf (dostep: 7.12.2018).

35 Rozporządzenie Ministra Środowiska z dnia 12 października 2011 r. w sprawie ochrony gatunkowej zwierzat http://prawo.sejm.gov.pl/isap.nsf/download.xsp/WDU20112371419/O/D20111419.pdf (dostęp: 7.12.2018).

36 Rozporządzenie Ministra Środowiska z dnia 6 października 2014 r. w sprawie ochrony gatunkowej zwierząt, http:// prawo.sejm.gov.pl/isap.nsf/download.xsp/WDU20140001348/O/D20141348.pdf (dostęp: 7.12.2018).

37 Rozporządzenie Ministra Środowiska z dnia 16 grudnia 2016 r., dz. cyt.

38 Na temat współczesnego statusu gawrona w Polsce zob. Z. Jakubiec, Gawron Corvus frugilegus w Polscestan poznania, perspektywy badawcze, w: L. Jerzak, B.P. Kavanagh, P. Tryjanowski (red.), Ptaki krukowate Polski, Poznań 2005

39 C. Jerolmack, How Pigeons Became Rats: The Cultural-Spatial Logic of Problem Animals, "Social Problems" 2008, t. 55.

40 N. Emery, Ptasia inteligencja: rozważania nad intelektem ptaków, przeł. D. Graszka-Petrykowski, Warszawa 2018

41 E. Woolfson, Corvus: życie wśród ptaków, przeł. A. Pluszka, J. Wajs, Warszawa 2012 


\section{„Plaga i niewinne stworzenia" - psy w przestrzeni publicznej Warszawy na przełomie XIX i XX wieku}

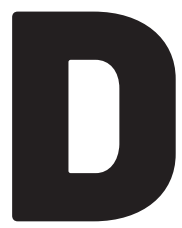

ruga połowa XIX wieku i początek XX to okres, w którym zmieniały się materialne oraz prawne ramy funkcjonowania psów w przestrzeni publicznej Warszawy. Jej mieszkańcy w nowy sposób zaczynali myśleć i o tych zwierzętach, i o ich obecności w mieście. Zanim jednak zostaną przedstawione te przekształcenia, należy przedstawić stan, który chciano zmieniać, a przynajmniej najważniejsze jego rysy. Dla zrozumienia działań reformatorów i ewolucji myśli kluczowe są pytania, gdzie i w jaki sposób przed zmianami psy były obecne w warszawskiej przestrzeni publicznej i jakie praktyki ludzkie organizowały ich życie. Znalezienie odpowiedzi na te pytania jest zadaniem trudnym, a wręcz karkołomnym, ponieważ trzeba wyciągać wnioski na podstawie pojedynczych sformułowań, a nawet słów.

\section{Gdzie i jak?}

W Lalce pojawia się tylko jedno takie słowo - „wypuszczał”. „W tym samym czasie zeskakiwał z kanapki jego stary pudel Ir z wybitym okiem i mocno otrząsnąwszy się, zapewne z resztek snu, skrobał do drzwi [...]. Pan Rzecki, wciąż ubierając się z pośpiechem, wypuszczał psa [...]”‥ Nie wiadomo, czy Ir wybiegał tylko na podwórze, czy wybierał się gdzieś dalej, ale bez wątpienia nie towarzyszył mu właściciel. Taki sam wniosek można wyciągnąć również z innego tekstu Prusa, który w jednej ze swoich kronik tygodniowych opisał historię niejakiego Filusia, „pieska pokojowego [...] herbu kundelek”2. Choć można mieć wątpliwości, jak traktować tę opowiastkę - całość ma formę listu napisanego przez samego Filusia - wzmianki dotyczące pewnych praktyk są warte uwagi. Filuś opisuje swoje przygody, z których jasno wynika, że po mieście porusza się bez właściciela. Skarży się na obowiązek noszenia przez psy na ulicy kagańców i przyznaje się, że czasami wychodzi z domu bez niego: „Jakkolwiek [...] posiadam aż dwa kagańce: rzemienny i żelazny, sam jednak żadnego włożyć nie potrafię, a mój pan nie zawsze domyśli się, kiedy mianowicie mam naglącą potrzebę wyjścia”. Dodaje, że od kiedy boi się wychodzić na ulicę bez kagańca, by nie zostać złapanym przez rakarzy, stał się „źródłem wielkich nieporząaków w mieszkaniu”, choć wcześniej był „tak wzorowy pod tym względem”. To jedynie opowieść Filusia, ale warto zwrócić uwagę nie tylko na to, że sam przemieszcza się po mieście, lecz także na to, że ani on, ani jego właściciel nie są przyzwyczajeni do rytmu regularnych 
spacerów, które mają pozwolić psu załatwić potrzeby fizjologiczne. O wypuszczaniu psów, a nawet wysyłaniu na podwórza, ulice i miasto pisali też inni ówcześni dziennikarze warszawscy ${ }^{3}$. Ci jednak zazwyczaj używali tych określeń - wypuszczanie oraz wysyłanie - w pewnej próżni, nie rozbudowywali tak jak Prus kontekstu, nie opisywali sytuacji, nie wchodzili w szczegóły, a to uniemożliwia stwierdzenie na podstawie samych tych źródeł, co dla ich autorów znaczyły te słowa. Trzeba więc zaufać ich znaczeniom. Choć oczywiście nie wszystko trafia do słowników, a zmiany poszczególnych znaczeń odnotowują one z dużym opóźnieniem, warto zauważyć, że słowniki języka polskiego z XIX i początku XX wieku nie podają definicji czasowników „wypuszczać” i „wysyłać” zupełnie innych od dzisiejszych ${ }^{4}$. Co ważniejsze, w ówczesnej prasie warszawskiej wypuszczanie pojawiało się jako praktyka osobna i różna od wyprowadzania ${ }^{5}$. Pewnych wskazówek dotyczących sposobów poruszania się psów po dziewiętnastowiecznej Warszawie dostarczają także wydawane w drugiej połowie XIX wieku przepisy regulujące sprawę ich obecności w mieście. W notatce oberpolicmajstra warszawskiego opublikowanej w 1865 roku można znaleźć potwierdzenie tego, że czworonogi nie zawsze pojawiały się wówczas w przestrzeni miasta pod nadzorem, ze swoimi właścicielami: „[...] nadmienia się, że poleconym zostało zwracać szczególną baczność, aby w mieście nie było psów bez nadzoru” ${ }^{6}$. Z kolei w rozporządzeniu z 1871 roku wśród wszystkich większych psów objętych nowymi przepisami osobną grupę stanowiły te „idące przy swoich panach”, w której nie mieściły się nie tylko „psy znajdujące się w bramach albo przed sklepami, aptekami, magazynami i na trotuarach”, lecz także „psy myśliwskie, pudle, psy z tabliczkami"”. Ze względu na to wszystko można zaryzykować stwierdzenie, że w dziewiętnastowiecznej Warszawie istniało więcej niż dzisiaj praktyk organizujących sposób przemieszczania się czworonogów po mieście, że wypuszczanie oraz wysyłanie ich na miasto było czymś innym niż wyprowadzanie i że psy wówczas tam mieszkające miały więcej swobody niż ich następcy, mogły bowiem przebywać w przestrzeni publicznej zarówno z właścicielem, jak i bez niego, a w związku z tym samotny pies w przestrzeni publicznej niekoniecznie oznaczał psa bezpańskiego. Być może wypuszczanie i wysyłanie ich na miasto różniło się od wyprowadzania rodzajem spełnianej funkcji. Być może niektóre psy wypuszczano, a inne wyprowadzano, może zależało to od pozycji społecznej i zamożności właściciela. Zarówno te kwestie, jak i pytania, która z tych praktyk była popularniejsza, a która wcześniejsza, muszę na razie pozostawić bez odpowiedzi.

Wszystkie te uwagi dotyczą psów mających właścicieli i mieszkających z nimi w domach lub mieszkaniach. W dziewiętnastowiecznej Warszawie żyły również psy podwórzowe, które strzegły obejścia i były, przynajmniej w ciągu dnia, uwiązane na łańcuchu, oraz psy bezpańskie. Jeśli przyjąć, że czworonogi mające właściciela pojawiały się czasami w Warszawie w XIX wieku na ulicy same, nie wiadomo, jak odróżniano je od bezpańskich. Na pewno w drugiej połowie XIX wieku pojęcia te - psy mające właściciela i psy bezpańskie - przeszły ewolucję wraz z pojawianiem się nowych przepisów oraz nowych przedmiotów. Warto zauważyć, że przynajmniej do początku XX wieku w innym kierunku niż dzisiaj odbywał się ruch wywożenia psów niechcianych. W 1886 roku na zebraniu zarządu warszawskiego Towarzystwa Opieki nad Zwierzętami ${ }^{8}$ przedstawiono wniosek „niewiadomego b. członka Towarzystwa o wystaranie się u właściwej władzy rozporządzenia, aby włościanom i innym osobom przybywającym do Warszawy wzbro-

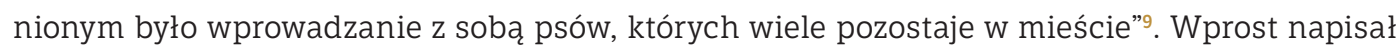
o tym w 1902 roku redaktor „Przyjaciela Zwierząt”, organu prasowego Towarzystwa. Wśród psów bezdomnych wyróżnił on grupę „psów przywożonych przez włościan, którzy nie chcąc lub nie mogąc ich dłużej trzymać, pozostawiają ich na ulicach naszego miasta i w ten sposób się ich pozbywają"10.

\section{Podatek, kaganiec i smycz}

W tym samym roku, w którym warszawski oberpolicmajster polecił pilnować, by psy nie przebywały w mieście bez nadzoru, Rada Administracyjna Królestwa Polskiego wprowadziła w Warszawie podatek od ich posiadania ${ }^{11}$. Opłata w wysokości jednego rubla rocznie za każdego posiadanego czworonoga została nałożona na wszystkich stałych i czasowych mieszkańców Warszawy oraz Pragi. Zdaniem autorów książki Opodatkowanie posiadania psów 
miała ona w XIX wieku w Europie przede wszystkim charakter podatku od luksusu, który trzeba było płacić jedynie za psy trzymane dla rozrywki, i dopiero z czasem zaczęła spełniać funkcje policyjno-sanitarne ${ }^{12}$. W Warszawie od początku podatek dotyczył wszystkich trzymanych psów niezależnie od rasy, nieważne więc było, czy pies służył do zabawy czy do pracy. Z innych źródeł wiadomo, że opłata ta obowiązywała również ludzi ubogich ${ }^{13}$. Podstawą do rozliczenia miały być listy tworzone przez właścicieli domów, którym za utajenie posiadania przez lokatora psa lub podanie nieprawdziwej liczby trzymanych czworonogów groziła podobna kara jak właścicielowi zwierzęcia. Wprowadzenie podatku tłumaczono względami ekonomicznymi - uzyskane środki miały zasilić kasę miejską ${ }^{14}$ - i bezpieczeństwem publicznym, czyli przede wszystkim walką ze wścieklizną. Ponieważ zakładano, że psy opłacone będą lepiej pilnowane przez właścicieli, liczono, że w ten sposób uda się ją zwalczyć, a przynajmniej ograniczyć jej zasięg. Podatek miał także przyczynić się do zmniejszenia liczby tych zwierząt w mieście-zgodnie z przepisami tylko psy opłacone mogły w nim przebywać, pozostałe miały być wyłapywane przez rakarzy. Z kolei dla funkcjonowa-

Ze względu na to wszystko można zaryzykować stwierdzenie, że w dziewiętnastowiecznej Warszawie istniało więcej niż dzisiaj praktyk organizujących sposób przemieszczania się czworonogów po mieście [...]. nia psów w przestrzeni pu-

blicznej ważniejsze od samego wprowadzenia podatku było nałożenie na właścicieli obowiązku zawieszania czworonogom u obroży blaszanego znaku potwierdzającego wniesienie opłaty, który otrzymywali wraz z kwitem z księgi sznurowej. Ten nowy element miejskiej ikonosfery pozwalał zmaterializować się, jeśli nie zaistnieć, różnicy między psami legalnie i nielegalnie przebywającymi w Warszawie. Rakarze mieli usuwać zwierzęta pozbawione znaczka. Podatek od posiadania psów rzeczywiście płacono. W 1894 roku w „Kurierze Warszawskim” opisano zamieszanie w kolejce do kasy poborowej na krótko przed upływem terminu płatności: „[...] dwie panie w tłoku zemdlały, a sporo osób, przeczekawszy do godz. 2-ej po południu, wyszło bez możności uiszczenia podatku" ${ }^{\prime 1}$. Nie oznacza to, że udało się osiągnąć stan zaprojektowany w przepisach z 1865 roku. Niecałe dwadzieścia lat po ich ogłoszeniu tylko za połowę psów przebywających w Warszawie płacono podatek. Wprowadzenie tej opłaty i jej późniejsze obowiązywanie nie wywołało w prasie warszawskiej większych sprzeciwów. Jedno z odważniejszych stanowisk zajął Bolesław Prus, który i w tej psiej sprawie zabrał głos. Pozornie protestował jedynie przeciwko podniesieniu podatku, ale w gruncie rzeczy podważał sensowność argumentów przyjętych między innymi przez Radę Administracyjną. Pisał, najwyraźniej lekceważąc zamysł prawodawców albo też negatywnie oceniając jego skuteczność: „[...] psi podatek z jadem wścieklizny nie mają najmniejszego związku i [...] pies wałęsający się tym się różni od innych, iż zazwyczaj nie posiada właściciela, który by płacił za niego nie wyższy, ale jakikolwiek podatek" ${ }^{16}$. Dodawał, że pozwala sobie na takie sądy, ponieważ zapłacił już 30 rubli za małego kundelka, który nie stał się wcale od tego zdrowszy. „Spostrzegłem nawet rzecz gorszą, że z każdym rokiem ja ulegam cięższym prześladowaniom sądu i policji, a mój pies coraz bardziej tyje i staje się słabszym" ${ }^{17}$. Głos Prusa był jednak odosobniony. Warszawskie Towarzystwo Opieki nad Zwierzętami protestowało jedynie wtedy, gdy władze lub osoby prywatne proponowały podatek od posiadania psów podnieść. Kontrowersje z nim związane były niczym w porównaniu z batalią przeciwko kagańcom.

W 1871 roku namiestnik Królestwa Polskiego, uznawszy, że dotychczasowe sposoby walki ze wścieklizną nie przynoszą pożądanych efektów, zarządził, aby wszystkie większe psy nosiły przez cały rok kagańce. Ten nakaz nie dotyczył zwierząt nieprzyzwyczajonych do kagańców i małych psów pokojowych, ale te mogły pojawiać się na ulicy tylko „na sznurkach lub łańcuszkach”, oraz „psów złośliwych”, które powinny być trzymane na uwięzi. Jednocześnie oberpolicmajster 
nie rezygnował z podatku od posiadania psów, choć przyznawał, że warto go utrzymać jedynie po to, by nie zmniejszyć dochodów kasy miejskiej. Swoją funkcję zachowała tylko tabliczka potwierdzająca uregulowanie podatku. Zgodnie z nowymi przepisami w przestrzeni publicznej mogły przebywać legalnie wyłącznie psy wyposażone właśnie w tabliczkę i w kaganiec. Wszystkie inne miały być usuwane przez „uprzątaczy” ${ }^{18}$. Choć w 1879 roku dziennikarz „Nowin” skarżył się: „Wprawdzie przepisy policyjne w tym względzie [zakładania psom kagańców] istnieją, ale stały się one tylko sentymentem, nikt nie uważa sobie za obowiązek do nich się stosować”, można się domyślać, że przynajmniej w pewnym stopniu były one egzekwowane, inaczej bowiem nie wywołałyby pewnie sprzeciwu. Warszawskie Towarzystwo Opieki nad Zwierzętami musiało wystąpić przeciwko kagańcom jeszcze w latach 70., ponieważ w rozporządzeniu z 1880 roku, w którym powtórzono przepisy z roku 1871, zresztą nie po raz pierwszy, generał-gubernator w odpowiedzi na prośbę zarządu Towarzystwa pozwolił zastąpić istniejący model kagańca modelem wygodniejszym dla psów. W kampanii przeciwko kagańcom brali też udział publicyści „Przyjaciela Zwierząt”. Chociaż protest ten ograniczał się do bardzo wąskiego środowiska - osoby spoza kręgu opiekunów i przyjaciół zwierząt czasami zabierały głos w tej w sprawie, ale stosunkowo rzadko - nie był tylko nic nieznaczącym epizodem, ale realnie wpływał na decyzje władz. Debatę zdominowały trzy argumenty. Pisano, że kagańce nie sprawdzają się jako środek walki ze wścieklizną. Zwracano uwagę na cierpienia fizyczne i „moralne”, które przeżywają psy zmuszone do noszenia kagańców. Wreszcie podkreślano, że same kagańce mogą wywoływać wściekliznę, ponieważ są bardzo szkodliwe dla zdrowia czworonogów, „czyli że ochraniając siebie, pomagamy rozwijać się tej chorobie u psów, zamiast przyczyny jej usuwać”, jak pisał dziennikarz i społecznik Julian Heppen ${ }^{19}$.

Ten sposób walki z wścieklizną budził kontrowersje nie tylko na ziemiach polskich - był on przedmiotem debaty publicznej również w innych częściach Europy, między innymi w Anglii. Za Johnem Waltonem większość badaczy zajmujących się przypadkiem angielskim powtarza, że protestowano tam przeciwko kagańcom przede wszystkim dlatego, że obawiano się ingerencji państwa w sprawy prywatne obywateli - psy, jak zauważa Walton, należały do rodziny - i tym samym ograniczenia wolności ${ }^{20}$. W Anglii, zdaniem Philipa Howella, kagańce były dla ich przeciwników zaprzeczeniem liberalizmu, symbolizowały ucisk państwa i kojarzyły się z rządami autorytarnymi, a to wszystko było całkowicie obce wartościom kultury brytyjskiej ${ }^{21}$. Co ważne, według niektórych badaczy nie była to tylko kwestia odczuć obywateli - państwo brytyjskie faktycznie chciało za pomocą kagańców i dyscyplinować właścicieli psów, i wciąż im o tym fakcie przypominać22.

Nie można wykluczyć, że warszawiacy protestujący przeciwko obowiązkowi zakładania psom kagańców myśleli o nim w sposób podobny do tego, który zdaniem badaczy zdominował umysły Brytyjczyków. Ponieważ jednak brak na to dowodów w materiale źródłowym, warto poszukać innych odpowiedzi na pytanie, dlaczego wprowadzenie kagańców budziło kontrowersje.

Z trzech przytoczonych wcześniej argumentów pierwszy wydaje się najmniej ważny. Przecież podatek od posiadania psów również okazał się nieskuteczny w walce z wścieklizną, a jednak nikt przeciwko niemu tak uparcie nie protestował, jak przeciwko kagańcom. Dwa pozostałe argumenty każą zwrócić uwagę na inny aspekt tej dyskusji, w jakiś sposób oczywisty, czyli na pojawiającą się w niej wizję relacji ludzko-psich czy szerzej: ludzko-zwierzęcych. Przeciwnicy obowiązku kagańcowego zgadzali się - co do tego nie ma wątpliwości - że zwierzęta mogą cierpieć i że człowiek nie powinien ich męczyć czy raczej nie powinien niepotrzebnie ich męczyć zgodnie z perspektywą wielokrotnie artykułowaną w „Przyjacielu Zwierząt”, bliską pewnie większości protestujących. Z kolei twierdzenie, że kagańce wywołują wściekliznę, było ściśle związane z popularną mimo odkryć Pasteura teorią „wścieklizny spontonima”23, czyli teorią spontanicznego rozwoju tej choroby (w wydanej w 1895 roku w Krakowie broszurze Wścieklizna u psów ${ }^{24}$ obydwie teorie służą autorom - Józefowi Limbachowi i Bronisławowi Gustawiczowi-do wyjaśnienia mechanizmu jej rozwoju). Twierdzono, że nie musi dojść do wymiany płynów między psem zdrowym a psem chorym, by u pierwszego rozwinęła się wścieklizna. Powtarzano, że „właściwą przyczyną wścieklizny u psów jest niedbałość ludzi”25. Tę chorobę miały wywoływać, jak pisali autorzy wspomnianej broszury: „pastwienie się nad [psami] i zupełne zaniedbanie, życie nienaturalne i rażący niestosunek płci obojej” oraz „brak wody i pożywienia”26. Do tej listy dodawano kagańce, ponieważ i były torturą dla psów, i zmuszały je do „życia nienaturalnego”, 
uniemożliwiając zaspokajanie podstawowych potrzeb fizjologicznych, takich jak picie i chłodzenie się. Taka etiologia wścieklizny pozwalała przeciwnikom kagańców zmieniać sposób myślenia, który zadecydował o ich wprowadzeniu oraz był umacniany przez ich obecność w przestrzeni publicznej. Kagańce noszone przez psy musiały przypominać warszawiakom, że są to zwierzęta zagrażające porządkowi publicznemu, czy raczej sprawiały, że psy je noszące takie się stawały w oczach obserwatorów. Kagańce wytwarzały nieprzekraczalną granicę między gatunkami. Frances Power Cobbe, irlandzka antywiwisekcjonistka, tak o tym mechanizmie pisała: „To, co mnie niepokoi w kagańcach, to to, że uczą one publiczność brytyjską patrzeć podejrzliwie i ze strachem, a w końcu z nienawiścią na zwierzęta, których przywiązanie do ludzkości było zawsze źródłem czystej i humanizującej przyjemności dla milionów”27. Ten właśnie sposób myślenia narzucany przez kagańce ich przeciwnicy odwracali za pomocą teorii o spontanicznym rozwoju wścieklizny. Ich zdaniem to człowiek był winny, a nie pies, i to jego trzeba było chronić przed człowiekiem, a nie na odwrót. W tej perspektywie „pies z natury nie jest złym lub złośliwym; [...] pies spokojny staje się takim dopiero przez złe, nieludzkie obchodzenie się z nim" ${ }^{28}$, jak podkreślali autorzy wspomnianej już broszury o wściekliźnie. W tym mechanizmie „uniewinniania”, w twierdzeniu, że psy są z natury dobre i dopiero przez człowieka stają się złe, w teorii tłumaczącej rozwój wścieklizny złym traktowaniem czworonoga przez człowieka, a zwłaszcza w wypowiedziach, w których główne przyczyny tej choroby upatrywano w pozbawianiu zwierzęcia możliwości zaspokajania popędu płciowego i zmuszaniu go do „życia nienaturalnego”, pobrzmiewały echa krytyki antycywilizacyjnej ${ }^{29}$. Wprost pisali o tym Limbach i Gustawicz:

Turcy nie znają psów wściekłych, bo też tam psy żyją życiem naturalnym, a Turek nie znęca się nad nimi. [...] Nawet u dzikich Australczyków psy są w poszanowaniu [...]. Zastanawiając się nad tymi objawami u ludzi mniej cywilizowanych lub zupełnie dzikich, przychodzimy mimo woli do przekonania, iż oni żyjąc życiem naturalnym, lepiej znają naturę w jej tajnikach i nauczyli się lepiej ją szanowaćc ${ }^{30}$

$\mathrm{Na}$ „uniewinnianiu” wywody o psiej naturze zazwyczaj się nie kończyły. Limbach i Gustawicz podkreślali:

Pies nie ogra cię w karty, nie oszuka, nie jest mściwy, liże nawet rękę, która go poniewiera, pies ci nie zakłóci spokojnego życia, nie oczerni, pies cię nie zdradzi, nie doradzi popełnienia złego czynu [...], nie opuści w nieszczęściu, chorobie i starości, podziela twoją radość i smuci się twoim smutkiem [...]. Pies całym życiem zasługuje sobie tylko na miano „wiernego”. Przymiot ten jest z istotą jego ściśle złączony, jest wyrazem jego istoty, bez którego nawet pomyśleć się nie da [...] $]^{31}$.

Ten sposób pisania o psach ma oczywiście długą tradycję, ale w XIX wieku, a w Warszawie w drugiej połowie tego stulecia, można zaobserwować nasilenie się takich tendencji. Coraz popularniejsza była pełna emocji i odwołująca się do wzajemnego przywiązania wizja psiej natury oraz relacji ludzko-psich. Choć w „Przyjacielu Zwierząt” niejednokrotnie krytykowano przesadnie emocjonalny stosunek do zwierząt, zwłaszcza psów, ukazywały się w nim - w pewnym okresie regularnie - artykuły o wiernych czworonogach ratujących swoich właścicieli z różnego rodzaju opresji i tracących ochotę do życia po ich śmierci ${ }^{32}$. Tę samą wizję przedstawiano na drukowanych w piśmie rycinach (il. 1).

Zważywszy na to wszystko, wydaje się, że w sposób uzasadniony można konflikt o kagańce interpretować zarówno jako próbę ulżenia cierpieniom psów, jak i szerzej jako spór o wizję psiej natury oraz relacji ludzko-psich. Kagańce ostentacyjnie przeczyły wizji psa niegroźnego, z natury dobrego i wiernego (tabliczki potwierdzające opłacenie podatku za czworonoga miały znacznie mniejszy potencjał znaczeniotwórczy i były zdecydowanie mniej widoczne). W tym kontekście wymowniejszy staje się argument przeciw kagańcom, którym miał posłużyć się zarząd warszawskiego Towarzystwa Opieki nad Zwierzętami, „iż używanie namordników należy uważać za środek przeciwny estetyce"33. 


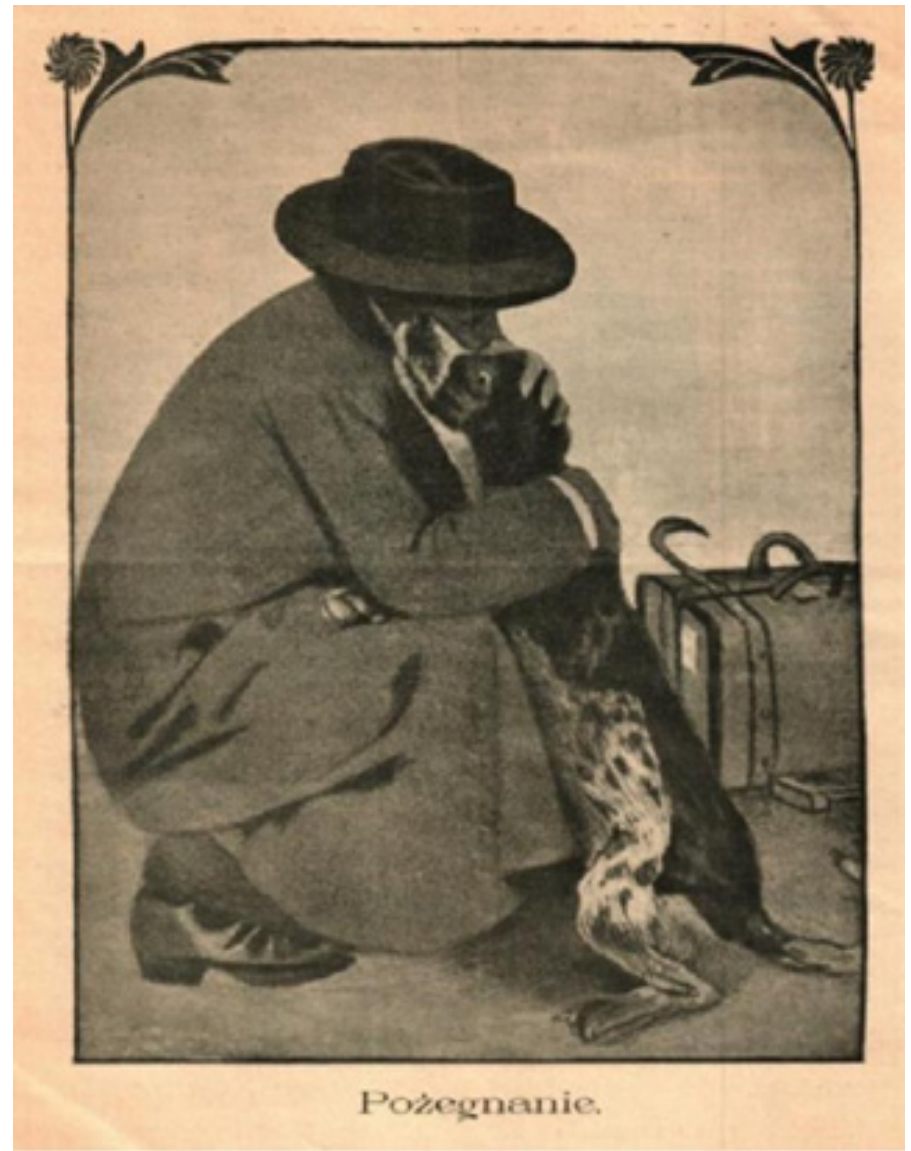

II. 1. Pożegnanie, "Przyjaciel Zwierząt” 1904, nr 1, s. 8

ŹRODŁO: BIBLIOTEKA NARODOWA W WARSZAWIE, DOMENA PUBLICZNA

Równie ważne jak argumenty przeciwko kagańcom były proponowane przez osoby je zwalczające inne rozwiązania tej sytuacji. Wszyscy, którzy protestowali przeciwko kagańcom, chcieli bowiem nie tyle je znieść, ile czymś je zastąpić. Propozycje były bardzo różne: od zachowawczego postulatu reformy kształtu kagańców, o czym już była mowa, po odważny głos Bolesława Prusa, który - najwyraźniej skłaniając się ku teorii wyjaśniającej rozwój wścieklizny niedostatkiem pożywienia i brakiem świeżej wody - zalecał „ustawić na ulicach korytka z wodą, [...] rzucać pokarm psom ubogim [...] jako prezerwatywy”34. Pomiędzy tymi skrajnościami mieściły się projekty Juliana Heppena i publicysty Stanisława Rewieńskiego, którzy chcieli ustanowienia wyższej niż obowiązujący podatek opłaty za trzymanie psów i wprowadzenia surowych kar dla właścicieli za nieodpowiednie zachowanie się ich pupili (z wysokiej opłaty Heppen chciał zwolnić suki, „których brak - jak pisał, zainspirowany najwyraźniej teorią wścieklizny spontomina przyczynia się też do rozwinięcia wścieklizny”35). Z kolei autor kronik miesięcznych ukazujących się w „Przyjacielu Zwierząt” proponował obejść obowiązek kagańcowy tak, żeby nie łamać przepisów, a wykorzystać możliwości przez nie stwarzane. Ponieważ zgodnie z rozporządzeniem z 1880 roku „psy prowadzone na sznurkach lub łańcuszkach” były zwolnione z noszenia kagańców, radził: „Niech [właściciel] sobie zada trud i prowadzi psa w obroży, a wtedy kaganiec będzie zbyteczny" ${ }^{36}$; że felietoniście chodziło o smycz, wiadomo z jednej z kolejnych jego kronik, opublikowanej kilka numerów później, w której pisał:

W jednej z poprzednich kronik miesięcznych, mówiąc o kagańcach dla psów i oceniając ich szkodliwość, wyraziliśmy odczucie, że za najwłaściwsze uważamy prowadzenie psów na smyczy. Zdanie nasze miało widocznie pewną rację bytu, gdyż dowiadujemy się, że dyrekcja policji w Wiedniu od 1-go maja r.b. zniosła nakaz nakładania psom kagańców [...]. Psy jednak wolno wyprowadzać na miejsca publiczne tylko na smyczy. Do naśladowania... ${ }^{37}$ 
Ton i postulatywny tryb tych artykułów, a także to, że przepisy odnosiły się do rzeczywistości, w której przynajmniej jakaś część psów mieszkających w mieście nie poruszała się na smyczy, świadczą o tym, że praktyka wyprowadzania pupili na linewce - używając jeszcze innego funkcjonującego wówczas określenia - nie była powszechna ${ }^{38}$. W przepisach policyjnych zawsze służyła jako rozwiązanie dodatkowe, nigdy nie została narzucona jako obowiązkowa. Nie była też przez wszystkich aprobowana. Kilku ze wspomnianych już autorów w smyczy widziało podobne zagrożenie dla zdrowia psa, co w kagańcu. Tak jak kaganiec smycz miała uniemożliwiać czworonogom zaspokajanie naturalnych potrzeb. Jak przekonywał Stanisław Rewieński: „Jeśli przechadzka miarowym krokiem jako środek higieniczny jest dla człowieka wystarczająca, to będzie ona zupełnie niedostateczna dla psa, który potrzebuje się wybiegać, węszyć po kątach, szukać zabawy z innymi psami, a nie kroczyć powoli jak kryminalista na łańcuchu"39. Zdaniem tego samego autora takie ograniczenie swobody zwierzęcia spowoduje, że nawet najłagodniejszy przedstawiciel psiego gatunku będzie, rozdrażniony, atakował na ulicy inne psy i przechodniów. Limbach oraz Gustawicz łączyli więzienie czworonogów w domach i wyprowadzanie ich na smyczy z pojawianiem się u nich różnych chorób, w tym wścieklizny. Echa tych kontrowersji pobrzmiewają w opowiadaniu etnografa i pedagoga Stanisława Polaczka o psie Azorze: „Gdy pan był w biurze, Azor całymi godzinami siadywał w oknie i patrzył swymi psimi oczyma [...] na towarzyszów biegających swobodnie po ulicy. Po południu wychodził z panem na przechadzkę, ale i tak wówczas nie był wolnym. Pan prowadził go na sznurku - jego rówieśnicy podbiegali często ku niemu i, drwiąc z jego niewoli, śmiechem mu w oczy parskali" ${ }^{4}$.

W wyniku dyskusji prasowych o kagańcach, a przede wszystkim wskutek działalności warszawskiego Towarzystwa Opieki nad Zwierzętami i powołania specjalnej komisji, warszawski oberpolicmajster w 1889 roku wydał rozporządzenie modyfikujące obowiązujące do tej pory przepisy. Obowiązek kagańcowy nie został zniesiony, ale pojawiła się alternatywa: psy zamiast kagańców mogły nosić obroże z nazwiskiem i adresem właściciela. Oprócz tego, aby legalnie przebywać w przestrzeni publicznej miasta, powinny być wyposażone - tak jak wcześniej-w tabliczkę potwierdzającą opłacenie za nie podatku. Nowością w stosunku do wcześniejszych rozporządzeń było obciążenie właścicieli odpowiedzialnością sądową za niestosowanie się do przepisów ${ }^{41}$.

\section{Kierunki działania i myślenia}

We wszystkich tych rozporządzeniach, działaniach warszawskiego Towarzystwa Opieki nad Zwierzętami i debatach prasowych widoczne są pewne tendencje. Po pierwsze - tak jak to zauważył w przypadku wiktoriańskiej Anglii John Walton ${ }^{42}$ - niekontrolowany pies, a właściwie pies pozbawiony oznak świadczących o kontroli ze strony człowieka przebywający w przestrzeni publicznej miasta zaczął być postrzegany jako coś nienormalnego i niepożądanego. Problemem stał się również, zwłaszcza w niektórych przestrzeniach (na przykład w ogrodach, o czym niżej), swobodnie biegający pies. Po drugie - w związku z tym, choć zależność przyczynowo-skutkowa nie przebiegała tu jednokierunkowo - władze Warszawy za zgodą szeroko pojętej opinii publicznej zaczęły dążyć do ograniczenia dostępu czworonogów do przestrzeni publicznej przez zawężanie kategorii tych, które mogą legalnie w niej przebywać, a tym samym do zmniejszenia ogólnej liczby zwierząt tego rodzaju w mieście i objęcia ich ściślejszą kontrolą. Oprócz tego z niektórych przestrzeni ogólnodostępnych psy, niezależnie od posiadania lub nieposiadania atrybutów legalności, były usuwane. Dotyczyło to przede wszystkim ogrodów i parków publicznych oraz sklepów rzeźniczych, masarni, z czasem też innych sklepów spożywczych. W pierwszej połowie XIX wieku wydano zakaz wprowadzania psów do ogrodów Saskiego i Krasińskich ${ }^{43}$. Przepis ten w zmienionej postaci został między innymi powtórzony w 1880 roku: bezwarunkowo zakazywano wówczas „wpuszczania do ogrodów publicznych wszystkich bez wyjątku psów, chociażby na uwiązaniu lub na ręku, z tej uwagi, że nie ma możności dopilnowania, ażeby psy przyprowadzone w ten sposób do ogrodów, nie zostały w czasie spaceru spuszczone swobodnie" 44 . Jeszcze w tym samym roku decyzja ta została powtórzona w osobnym rozporządzeniu dotyczącym ogrodu Krasińskich: psy wraz z żebrakami, pijakami, ulicznikami, osobami ubranymi nieprzyzwoicie i nieczysto, „,izraelitami w odzieży długiej kroju 
wzbronionego", dziećmi urządzającymi zbyt krzykliwe zabawy oraz ludźmi z noszami, tłumokami, ciężarami i koszami znalazły się na liście elementów zakłócających porządek w ogrodzie, które należało usunąć ${ }^{45}$. Z kolei do sklepów sprzedających mięso i inne artykuły spożywcze zakazano wpuszczania psów przede wszystkim ze względów higienicznych. Tendencja do ograniczania dostępu czworonogów do miejskiej przestrzeni publicznej przyjmowała czasami skrajne postaci. Wojciech Szukiewicz na łamach „Nowin” w 1904 roku pisał: „[...] ściśle biorąc, w tak wielkim i cywilizowanym mieście, jak Warszawa, psów wcale być nie powinno, bo to tylko źródło niebezpieczeństw i ofiar w ludziach" ${ }^{46}$. W tej wypowiedzi szczególnie wyraźnie widać jeszcze inną tendencję - do myślenia o przestrzeni miasta jako o takiej, która powinna być bezpieczna. W mieście człowiek nie tylko nie powinien być „kaleczony”, „szarpany” czy „kąsany” przez psy lecz także nie powinien przez nie „nabawiać się silnego przestrachu”, zwłaszcza kobiety i dziecijak pisano w kolejnych rozporządzeniach policyjnych. Wspominany dziennikarz „Nowin”, który narzekał, że warszawiacy nie stosują się do przepisu o kagańcach, domagał się przestrzegania ich po to, by letnią porą rodzice mogli bez obawy „wysyłać na przechadzkę dzieci”47.

Ograniczanie dostępu psów do przestrzeni publicznej Warszawy wiązało się także ze zwiększaniem roli ich właścicieli. Już samo wprowadzenie podatku od posiadania psów i blaszanego znaku, obowiązku kagańcowego czy obroży z nazwiskiem oraz adresem właściciela wymagało od niego większego zaangażowania się w opiekę nad pupilem. To przywiązywanie właściciela do psa, ale też psa do właściciela odbywało się na kilka sposobów, na różnych płaszczyznach. Podatek sprawiał, że właściciel zaczynał łączyć pupila z określoną wartością pieniężną, a warto przy tym pamiętać, że utrzymanie psa w Warszawie w drugiej połowie XIX wieku mogło kosztować niewiele lub prawie nic. Jednocześnie w coraz większym stopniu stosunek ludzi do tych zwierząt kształtowały emocje, i to w coraz szerszych kręgach. Do zacieś-

\section{Do zacieśniania relacji dochodziło również} w przestrzeni. Duet właściciel-pies obok samotnie poruszających się czworonogów zdobywał stałe miejsce w krajobrazie warszawskiej ulicy. niania relacji dochodziło również w przestrzeni. Duet właściciel-pies obok samotnie poruszających się czworonogów zdobywał stałe miejsce w krajobrazie warszawskiej ulicy. Funkcjonować mógł na różnych zasadach: mógł to być nadzór właściciela nad psem bez używania jakichś szczególnych narzędzi bądź mogło być to związanie dosłowne za pomocą smyczy lub symboliczne - poprzez noszoną przez zwierzę obrożę z nazwiskiem i adresem właściciela. Nie dość tego, w związku z ograniczaniem dostępu psów do przestrzeni publicznej i właśnie przywiązywaniem do człowieka podstawowym oraz właściwym miejscem przebywania czworonoga w mieście - tak jak to zauważył między innymi Philip Howell ${ }^{48}$ - zaczynał być dom właściciela zamiast ulicy czy podwórza. Wreszcie ułatwienie identyfikacji psa z właścicielem umożliwiło realizację w pewnym stopniu tego, czego żądali Julian Heppen i Stanisław Rewieński: obarczenia właściciela odpowiedzialnością za zachowanie pupila w przestrzeni publicznej. Do rozporządzenia z 1889 roku, które wprowadziło odpowiedzialność sądową właścicieli za niestosowanie się do przepisów, to pies przede wszystkim ponosił konsekwencje tego, że człowiek nie wyposażył go w odpowiednie atrybuty legalności. To on był łapany, wywożony do rakarza, gdzie albo przechowywano go przez kilka dni i sprzedawano, albo zabijano. Właściciel był karany (finansowo) tylko wtedy, gdy postanowił wykupić psa od rakarza, ale robić tego nie musiał. Wszystkie te zmiany powodowały, że pies w coraz mniejszym stopniu był samodzielnym aktorem życia miasta.

Zdaniem Philipa Howella taką interpretację zmian dotyczących obecności psów w modernizującym się dziewiętnastowiecznym mieście europejskim, którą on określa mianem dyscyplinującej, należy uzupełnić - jeśli nie podać w wątpliwość - historią o tym, jak przestrzeń takiego miasta otwierała się na psy i ich właścicieli, jak psy stawały się częścią nowoczesności. 
Tę pozytywną interpretację buduje na przykładzie wiktoriańskiego i edwardiańskiego Londynu, przeciwstawiając sobie dwa przedmioty: kaganiec i smycz. Kaganiec jest tu narzędziem represji - bezpośrednio, fizycznie dyscyplinującym zwierzę, smycz zaś „liberalną alternatywą”, poddającą kontroli przede wszystkim właścicieli, sprzyjającą kształtowaniu wśród nich odpowiedzialności za pupili, włączającą psy w przestrzeń publiczną. Tak Howell rekonstruuje stanowisko tych Brytyjczyków z końca XIX wieku, którzy uczestniczyli w debatach o warunkach, na jakich zwierzęta tego rodzaju mogły być obecne w mieście. Można się zastanawiać, w jakim stopniu taka interpretacja i takie przeciwstawienie kagańca oraz smyczy - które równie dobrze można by widzieć jako przejście od Foucaultowskiej kaźni do dyscypliny, mimo że Howell bardzo chce zerwać z tą tradycją - są uzasadnione i w kontekście brytyjskim, i jako stwierdzenia dotyczące całej ówczesnej Europy. Tu muszę poprzestać na stwierdzeniu, że w warszawskich dyskusjach dotyczących miejsca psa w przestrzeni miasta tendencji takich raczej odnaleźć się nie da: kaganiec, owszem, był postrzegany jako narzędzie tortur i zniewolenia, ale smycz w najlepszym razie jedynie jako „sposób usunięcia jak na teraz [...] przepisu policyjnego [dotyczącego kagańców]"49. Ale Howell wspomina również o innym aspekcie tego zapraszania psów i ich właścicieli do nowoczesnego miasta: o przekształcaniu przestrzeni publicznej zgodnie z potrzebami czworonogów. Skupia się na działalności Metropolitan Drinking Fountain and Cattle Trough Association, które od połowy lat 60. XIX wieku zajmowało się zakładaniem poideł dla psów w parkach i przy drogach. W Warszawie z taką inicjatywą wystąpiło w latach 90. XIX wieku Towarzystwo Opieki nad Zwierzętami i tu raczej - ostrożnie - należy szukać tendencji wskazanych przez Howella. Pomysł też dosyć szybko przeszedł z fazy apeli (pierwsza połowa lat 90.) do fazy realizacji (druga połowa lat 90.). Od początku miał poparcie władz miasta, czasem nawet finansowe. W 1896 roku sprawą zainteresował się działający przy warszawskim Towarzystwie Opieki nad Zwierzętami Komitet Damski, który w związku z wystawą higieniczną poprosił budowniczych o przedstawienie projektów poideł dla psów. Zamiast budowania fontann zdecydowano się wmurowywać kamienne pojemniki pod kranami do polewania ulic znajdującymi się w ścianach domów. W 1899 roku donoszono, że takich poideł było w Warszawie pięć, dziesięć lat później było ich już zaś pięćdziesiąt. Pomysłodawcy konieczność wprowadzenia urządzeń tego typu tłumaczyli skanalizowaniem miasta (kanalizację Warszawy ukończono właściwie do 1900 roku): dopóki były rynsztoki i kałuże, w nich psy mogły zaspokajać - wprawdzie zanieczyszczoną wodą - pragnienie. Można się zastanawiać, czy poidła nie są przede wszystkim wynalazkiem miasta skanalizowanego również dlatego, że dopiero w takich warunkach mógł upowszechnić się pogląd, zgodnie z którym zarówno ludzie, jak i zwierzęta powinni pić czystą oraz świeżą wodę. Na tym poziomie analizy nie ma wątpliwości, że za pomocą poideł przestrzeń skanalizowanej Warszawy była dostosowywana do potrzeb psów. Obraz ten trzeba jednak zniuansować, uważnie przyglądając się intencjom pomysłodawców, a te - jak się wydaje - między początkiem lat 90. XIX wieku a pierwszą dekadą XX wieku uległy zmianie. Nie przez przypadek członkinie Komitetu Damskiego warszawskiego Towarzystwa Opieki nad Zwierzętami zainteresowały się poidłami w związku z wystawą higieniczną, na której prezentowały urządzenia pomagające zachować warunki higieniczne w stosunku do zwierząt „wpływające bezpośrednio na zdrowie człowieka i na jego dobrobyt" ${ }^{50}$. Początkowo poidła traktowane były jako narzędzie walki ze wścieklizną 51 (z powodu niezaspokojonego pragnienia pies może się wściec; taką funkcję poidłom przypisywał Prus), a przynajmniej sposób na uchronienie przechodniów przed atakami ze strony tych zwierząt, „stanowczo niebezpiecznych dla [nich], bo często rozdrażnionych li tylko brakiem wody" ${ }^{2}$. Dlatego też w Warszawie poidła budowano z myślą - jeśli nie przede wszystkim, to także - o psach bezdomnych (zdaniem Howella w Londynie poidła były tak umieszczane, aby mogły z nich korzystać głównie psy mające właścicieli , czyli „szanowani psi obywatele"). Dopiero z czasem w warszawskiej dyskusji o budowaniu poideł ważnym argumentem stały się potrzeby i cierpienia psa: pisano o „poczuciach humanitarnych” (których - jak ubolewano - część warszawskiej publiczności była pozbawiona, ponieważ traktowała poidła jak popielniczki ${ }^{53}$ ), „nieszczęśliwych zwierzętach, biegających ulicami, na próżno szukających, gdzie by mogły ugasić pragnienie”, „najstraszniejszych mąkach” i „cierpieniach, jakie powoduje pragnienie" ${ }^{54}$. Pewne pomysły rozwiązań dostosowujących nowy sposób funkcjonowania Warszawy wynikający z modernizacji infrastruktury do potrzeb czworonogów pojawiły się również po uruchomieniu tramwajów elektrycznych. Jak donoszono na łamach „Przyjaciela Zwierząt”: 
„W pierwszych miesiącach uruchomienia tramwajów elektrycznych w Warszawie przejeżdżano, jak wskazują dane, zaczerpnięte w naszym Tow. op. n. zw., po 30 psów tygodniowo!”55. Tej „formalnej epidemii przejeżdżania, przeważnie na śmierć, psów”56 przeciwdziałali przede wszystkim opiekunowie cyrkułowi z Towarzystwa Opieki nad Zwierzętami (uważano, że przynajmniej część wypadków to wina właścicieli zwierząt, zaczęto więc pociągać ich do odpowiedzialności), ale też na zebraniu Towarzystwa w 1909 roku jeden z członków, p. A. Funk, zaproponował, żeby „Zaprowadzić przy tramwajach sikawki celem odstraszania psów, które w tak znacznej liczbie są przejeżdżane" ${ }^{57}$. Jednak tym razem, zamiast dostosowywać przestrzeń miasta do psów, postanowiono dostosować psy oraz ich właścicieli do istniejących warunków i nauczyć ich w tych warunkach funkcjonować.

Niemniej nie ma wątpliwości, że tendencja do myślenia o psach w kategoriach ich potrzeb i odczuć oraz do szukania rozwiązań pozwalających jednocześnie sprostać wymogom nowoczesnego miasta i jak najmniej szkodzić tym zwierzętom była widoczna również nad Wisłą, a jej najbardziej wyrazistym przykładem stała się dyskusja dotycząca kagańców oraz innych środków regulujących obecność czworonogów w przestrzeni publicznej. Choć rozgorzała w określonym, niezbyt licznym środowisku opiekunów i przyjaciół zwierząt, była nie mniej ważna niż ograniczanie dostępu psów do przestrzeni publicznej miasta i zwiększanie roli właściciela; miała realny wpływ na decyzje władzy i w jakimś stopniu kształtowała rzeczywistość. Działania i dyskusje dotyczące sposobu funkcjonowania psów w modernizującej się Warszawie były więc rozpięte między tymi dwoma biegunami. Najlepiej to napięcie oddaje wypowiedź cytowanego już Wojciecha Szukiewicza, który w jednym i tym samym zdaniu pisał o smutnym i pożałowania godnym losie czworonogów, a także o tym, że psy „to tylko źródło niebezpieczeństwa i ofiar w ludziach”. Zaraz też dodawał, że zwierzęta te to plaga, ale też niewinne stworzenia: „[...] plagę też znosić musimy i musimy usiłować niewinne te stworzenia chronić od niezasłużonego cierpienia, na jakie obecnie większość psów jest niestety narażona”58.

\section{PRZYPISY}

1 B. Prus, Lalka, Warszawa 1981, s. 23.

2 Tenże, Kronika tygodniowa, „Kurier Warszawski” 1886, nr 114b, s. 4.

3 Zob. Psy, dzięki uprzejmości..., "Nowiny” 1879, nr 119, s. 3; J. Heppen, O kagańcach, „Przyjaciel Zwierząt” 1888 , nr 4, s. 6

4 Zob. S.B. Linde (red.), Słownik języka polskiego, t. 6, Warszawa 1814; A. Zdanowicz (red.), Słownik języka polskiego, Wilno 1861; J. Karłowicz, A. Kryński, W. Niedźwiedzki (red.), Słownik języka polskiego, t. 7, Warszawa 1919.

5 S. Rewieński, Czy kagańce dla psów odpowiadaja celowi?, "Opiekun Zwierząt Domowych i Pożytecznych" 1883, nr 7, s. 52.

6 Dostrzeżonem zostało..., „Warszawska Gazeta Policyjna” 1865, nr 59, s. 1.

7 W rozkazie Warszawskiego Oberpolicmajstra do Policji Wykonawczej nr 62, „Warszawska Gazeta Policyjna" 1871, nr 49, s. 2

8 W początkach działalności był to właściwie warszawski oddział Rosyjskiego Towarzystwa Opieki nad Zwierzętami, otwarty pod koniec lat 60. XIX wieku. Dokładna data utworzenia oddziału warszawskiego nie jest pewna. Obecnie istniejące ogólnopolskie Towarzystwo Opieki nad Zwierzętami, które nawiązuje do tradycji tego dziewiętnastowiecznego towarzystwa warszawskiego, jako date założenia podaje 1 listopada 1864 roku (http://www.toz.pl/?menu=o_nas, dostęp: 26.10.2020). Data ta pojawia się też w literaturze przedmiotu (M. Gajewski, Urzadzenia komunalne Warszawy: zarys historyczny, Warszawa 1979, s. 226; L. Prorok, Zapiski psubrata, Wrocław 1977, s. 75), inne jednak informacje podaja źródła. W 1864 roku najprawdopodobniej utworzono towarzystwo w Petersburgu (zob. Od Zarządu, "Przyjaciel Zwierząt" 1895, nr 12, s. 11). W organie warszawskiego Towarzystwa Opieki nad Zwierzętami, w "Przyjacielu Zwierząt", oraz W "Warszawskiej Gazecie Policyjnej" wprost jest podawana data 1868 (Opieka nad zwierzętami (ciag dalszy), „Warszawska Gazeta Policyjna” 1897, nr 121, s. 3; Z.F., Ochrona zwierzat, „Przyjaciel Zwierząt” 1886, nr 5 , s. 3), ale jednocześnie z "Przyjaciela Zwierząt" wiemy, że dwudziestopięciolecie towarzystwa obchodzono W 1895 roku, a wówczas założenie przypadałoby na rok 1870 (zob. np. Od Zarząu, "Przyjaciel Zwierząt" 1895, nr 7, s. 11). W całym artykule używam skrótowej nazwy: warszawskie Towarzystwo Opieki nad Zwierzętami.

9 Protokół miesięcznego zebrania członków zarządu Towarzystwa Opieki nad Zwierzętami, „Przyjaciel Zwierząt" 1886, nr 4, s. 4.

10 P.P. Pawlicki, Przytułek dla psów, „Przyjaciel Zwierząt” 1902, nr 2, s. 16 
11 W Imieniu Najjaśniejszego Alexandra II..., „Warszawska Gazeta Policyjna” 1865, nr 63, s. 1. W Anglii podatek od psów wprowadzono w 1796, natomiast we Francji w 1856 roku. Zob. S. Barles, Undesirable Nature: Animals, Resources and Urban Nuisance in Nineteenth-Century Paris, w: P. Atkins (red.), Animal Cities. Beastly Urban Histories, Farhnam 2012, s. 181. Fragmenty tej pracy w polskim tłumaczeniu w tym tomie, zob. Zwierzęce nieczystości i utrapienia w dziewiętnastowiecznym Londynie, przeł. J. Schollenberger.

12 C. Kosikowski, J. Matuszewski, Opodatkowanie posiadania psów, czyli płacz ze śmiechu wokół budy, Warszawa 2002, s. 157-164. Fragmenty tej pracy w polskim tłumaczeniu w tym tomie, zob. Zwierzęce nieczystości i utrapienia w dziewiętnastowiecznym Londynie, przeł. J. Schollenberger.

13 Protokół posiedzeń Zarzq̨du Towarzystwa Opieki nad Zwierzętami, „Przyjaciel Zwierząt” 1904, nr 4, s. 9.

14 Wysokość wpływów do kasy miejskiej z podatku od posiadania psów zob. H. Radziszewski, Warszawa, t. 2: Gospodarstwo miejskie, Warszawa 1915, s. 393-394.

15 Na ostatnia chwilę..., „Kurier Warszawski” 1894, nr 97, s. 5.

16 B. Prus, Kronika tygodniowa, "Kurier Codzienny" 1887, nr 335, s. 2

17 Tamże.

18 W rozkazie Warszawskiego Oberpolicmajstra do Policji Wykonawczej za Nr 62 wydanym, „Warszawska Gazeta Policyjna" 1871, nr 49, s. 1-2.

19 J. Heppen, O kagańcach, dz. cyt., s. 7. Inne głosy w tej dyskusji zob.: S. Rewieński, Czy kagańce..., dz. cyt. B. Prus, Kronika tygodniowa, "Kurier Warszawski” 1886, nr 114b, s. 4; C.R., Kronika miesięczna, "Przyjacie Zwierzat" 1888, nr 3, s. 4; Sprawozdanie z działań warszawskiego oddziału..., „Przyjaciel Zwierzatt” 1889, nr 11 dodatek, s. 2 .

20 J. Walton, Mad Dogs and Englishmen: the Conflict Over Rabies in the Late Victorian England, Journal of Social History" 1979, nr 2, s. 219-239; H. Kean, Animal Rights: Political and Social Change in Britain since 1800, London 1998, s. 91-92; P. Howell, Between the Muzzle and the Leash: Dog-walking, Discipline, and the Modern City, w: P. Atkins (red.), Animal Cities..., dz. cyt.; N. Pemberton, M. Worboys, Mad Dogs and Englishmen: Rabies in Britain, 1830-2000, New York 2007.

21 P. Howell, Between the Muzzle..., dz. cyt., s. 230

22 Tamże, s. 236; N. Pemberton, M. Worboys, Mad Dogs..., dz. cyt., s. 162.

23 C.R., Kronika miesięczna, „Przyjaciel Zwierząt” 1888, nr 11, s. 1-2.

24 J. Limbach, B. Gustawicz, Wścieklizna u psów, Kraków 1895

25 Rozmaitości, „Miesięcznik Galicyjskiego Towarzystwa Ochrony Zwierząt” 1876, nr 2, s. 30.

26 J. Limbach, B. Gustawicz, Wścieklizna u psów, dz. cyt., s. 7, 11. Zob. też C.R., Kronika miesięczna, „Przyjaciel Zwierząt" 1888, nr 11, s. 1-2.

27 Cyt. za: N. Pemberton, M. Worboys, Mad Dogs..., dz. cyt., s. 142 (przeł. A.J.)

28 J. Limbach, B. Gustawicz, Wścieklizna u psów, dz. cyt., s. 9.

29 O krytyce nowoczesności, a zwłaszcza o krytyce kultury mieszczańskiej w ramach dyskusji o wścieklizny we Francji pisze Kathleen Kete, La Rage and the Bourgeoisie, w: taż, The Beast in the Boudoir. Petkeeping in Nineteenth-Century Paris, Berkeley 1994.

30 J. Limbach, B. Gustawicz, Wścieklizna u psów, dz. cyt., s. 7.

31 Tamże, s. 8

32 Wierny pies, „Przyjaciel Zwierząt” 1905, nr 7, s. 11; S. Polaczek, Wierny, „Przyjaciel Zwierząt” 1907, nr 8, s. $127-129$

33 Opieka nad zwierzętami, „Warszawska Gazeta Policyjna” 1897, nr 134, s. 3.34 B. Prus, Kronika tygodniowa, „Kurier Codzienny 1887, nr 335, s. 2 .

35 J. Heppen, O kagańcach, dz. cyt., s. 7

36 C.R., Kronika miesięczna, „Przyjaciel Zwierząt” 1888, nr 3, s. 4.

37 Tenże, Kronika miesięczna, „Przyjaciel Zwierząt” 1888, nr 6, s. 4

38 O tym, że wyprowadzanie psów na smyczy w mieście było wówczas praktyką mało powszechną i stosunkowo nową jako sposób codziennego poruszania się właścicieli i ich pupili w miejskiej przestrzeni publicznej, mogą świadczyć również w pewnym stopniu słownikowe znaczenia słowa "smycz" powtarzane w będacych wówczas w obiegu słownikach języka polskiego, odnoszące się wyłącznie do praktyk myśliwskich wykorzystujących ten przyrząd. W słowniku Lindego smycz to "rzemień, na którym charty na polo wanie prowadzą, a potem je z niego zmykają" (wcześniejsza forma słowa "smycz" to "smyk"; S.B. Linde (red.), Słownik języka polskiego, dz. cyt., t. 3). Powtarzali tę definicję wszyscy dziewiętnastowieczni leksykografowie, a nawet autorzy wydanego już w początkach XX wieku tak zwanego słownika warszawskiego. Zob. A. Zdanowicz (red.), Słownik języka polskiego, dz. cyt.; E. Rykaczewski, Słownik języka polskiego podług Lindego i innych nowszych źródeł, Berlin 1866; J. Karłowicz, A. Kryński, W. Niedźwiedzki (red.), Słownikjęzyka polskiego, t. 6, Warszawa 1915; A. Brückner, Słownik etymologiczny języka polskiego, Kraków 1927. W znaczeniu współczesnym słowo "smycz" pojawia się dopiero w wydanym po II wojnie światowej Słowniku języka 
polskiego Witolda Doroszewskiego (Warszawa 1958-1969), co należy traktować jako jeszcze jeden dowód na opóźnienie stanu słownikowego względem rzeczywistości.

39 S. Rewieński, Czy kagańce..., dz. cyt., s. 52-53

40 S. Polaczek, Wierny, dz. cyt., s. 127

41 Rozporzadzenie Ober-Policmajstra m. Warszawy, „Warszawska Gazeta Policyjna” 1889, nr 102, s. 1-2.

42 J. Walton, Mad Dogs..., dz. cyt., s. 226

43 Władza Policyjna ogłosiła..., „Kurier Warszawski” 1841, nr 216, s. 1030

44 W rozkazie Warszawskiego Ober-Policmajstra do policji Wykonawczej za № 4 zamieszczono..., „Warszawska Gazeta Policyjna" 1880, nr 7, s. 2

45 W dzisiejszym rozkazie p. oberpolicmajstra $m$. Warszawy..., „Kurier Warszawski” 1880, nr 102, s. 3

46 W. Szukiewicz, Popierajmy!, "Ziarno" 1904, nr 12, s. 229.

47 Psy, dzięki uprzejmości..., dz. cyt

48 P. Howell, Between the Muzzle..., dz. cyt., s. 226

49 C.R., Kronika miesięczna, "Przyjaciel Zwierząt” 1888, nr 3, s. 4.

50 Wystawa Komitetu Damskiego, „Przyjaciel Zwierząt” 1896, nr 7, s. 2

51 Zob. np. Od Zarządu warszawskiego Tow. Opieki nad Zwierzętami, „Przyjaciel Zwierząt” 1893, nr 10, s. 12

52 Poidła dla psów, „Kurier Warszawski” 1908, nr 207, s. 3

53 Zob. Poidła uliczne dla psów w Warszawie, „Przyjaciel Zwierząt” 1909, nr 6, s. 90-91; Przed kilku laty... "Kurier Warszawski” 1909, nr 143, dodatek poranny, s. 2; Poidła dla psów, dz. cyt., s. 3.

54 Poidła uliczne..., dz. cyt. ; Opieka nad zwierzętami c.d., "Warszawska Gazeta Policyjna” 1897, nr 137, s. 2.

55 Przejeżdżanie psów, „Przyjaciel Zwierząt” 1908, nr 12, s. 188.

56 M. Malcz, Głosy członków, „Przyjaciel Zwierząt” 1908, nr 5, s. 73.

57 Protokół posiedzenia Zarzadu Warszawskiego Towarzystwa opieki nad zwierzętami z d. 2/15 października 1909 r., „Przyjaciel Zwierząt” 1909, nr 12, s. 189.

58 W. Szukiewicz, Popierajmy!, dz. cyt. 


\section{Zauważone! - zmiana stosunku do koni w Krakowie na przełomie XIX i XX wieku}

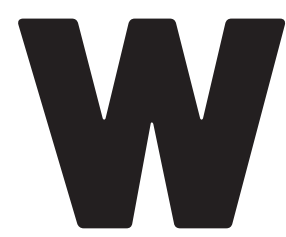

euroamerykańskim wieku XIX siła koni została wykorzystana w maksymalnym zakresie, ówczesne miasta praktycznie nie mogły się obyć bez tych zwierząt. Nie tylko stanowiły one siłę napędową, lecz także stawały się często katalizatorem rozwoju gospodarczego ${ }^{1}$. Bogate metropolie, takie jak Londyn, Paryż czy Nowy Jork, nie powstałyby bez koni. Egzystencja koni miejskich kształtowała się inaczej w porównaniu z życiem ich wiejskich odpowiedników. Jak zauważają Clay McShane i Joel Tarr, miejskie konie bez wątpienia pracowały znacznie ciężej, ale jednocześnie ich warunki życia wciąż się poprawiały w zestawieniu z panującymi na wsi. Były lepiej karmione i dłużej żyły. Dziewiętnastowieczni przedsiębiorcy cenili je, przede wszystkim ze względu na własne zyski. Dla nich były to żywe maszyny. Konie napędzały maszyny w fabrykach, przewoziły wodę w mieście, były wykorzystywane do jej pompowania, umożliwiały pracę różnego rodzaju sprzętów budowlanych, a przede wszystkim rozwój transportu miejskiego. Istniejące współcześnie muzea techniki pełne są eksponatów będących namacalnym dowodem roli, jaką odegrały one w rozwoju ludzkości².

Według spisu ludności z 1880 roku w Krakowie mieszkało 59828 osób. W tym samym spisie doliczono się w mieście 493 koni³ $^{3}$. Dla porównania w Warszawie mniej więcej w tym samym czasie liczbę koni szacowano na około $17000^{4}$, a na początku XX wieku na około $15000^{5}$. Wówczas ludność miasta liczyła około $624000^{6}$. Gdy zestawia się te dwa miasta, dysproporcje w liczbie koni wydają się znaczące. Należy jednak mieć na uwadze, że Kraków znacznie rozrósł się w pierwszych dziesięcioleciach XX wieku. Spis powszechny z 1900 roku wykazał już 1202 konie, a kolejny, z 1910 roku, zarejestrował obecność 1771 zwierząt. Te same spisy wykazały 85000 mieszkańców w roku 1900 i 142000 w 19107. Ten ostatni został przeprowadzony tuż po rozpoczęciu realizacji planu zagospodarowania przestrzennego, którego efektem miało być powstanie tak zwanego Wielkiego Krakowa. Wówczas, zgodnie z koncepcją prezydenta Juliusza Lea, w obręb miasta zaczęto wcielać kolejne wsie, które otrzymywały status dzielnic ${ }^{8}$. Skok liczebności koni pomiędzy 1900 a 1910 rokiem był znaczny i sięgnął prawie 40 procent. Jak zauważyli ówcześni komentatorzy, wynikał także ze wzrostu popularności zarobkowania przez wynajem furmanek i dorożek oraz świadczonych w tej materii usług ${ }^{9}$. W tej liczbie dominującą rolę odgrywały konie, które przez większość życia pracowały na krakowskich ulicach, ciągnąc pojazdy prywatne, zarówno te zbytkowe, jak i użytkowe. Przede wszystkim były one wykorzystywane na szeroką skalę 
przez służby i przedsiębiorstwa działające na terenie miasta, na przykład straż pożarną, służby oczyszczania miasta, pogotowie ratunkowe czy spółkę tramwajową.

Choć konie stanowiły powszechny widok na ulicach miasta, ich wartość była znaczna. W Krakowie konie robocze, nazywane również „chłopskimi”, można było kupić średnio za 10, a nawet 15 złotych reńskich ${ }^{10}$. Cena dobrego konia roboczego sięgała jednak nawet 40 złotych reńskich. Jeszcze droższe były lepsze konie pociągowe, które określano także „pańskimi”; za nie płacono od 50 do 100 złotych reńskich. Niewielu nabywców w mieście znajdowały konie wierzchowe, które wyceniano na 130 złotych reńskich ${ }^{11}$.

Konie w Krakowie kojarzone były przede wszystkim z królującymi na Rynku Głównym dorożkami. W 1850 roku było ich w Krakowie 2912. Początkowo były to dwukonne, nieco toporne pojazdy, obsługiwane przez fiakrów. W roku 1855 pojawiły się lekkie dorożki jednokonne, nazywane „cypcerówkami” od Józefa Cypcera, który wprowadził je jako pierwszy ${ }^{13}$.

Te niezbędne ku wygodzie publicznej powozy dotąd niepotrzebnie zaprzęgano parą koni, kiedy jeden tąż samą posługę dopełnić może, a oszczędność przy żywieniu drugiego konia będzie znaczną [...], a urośnie stąd korzyść i dla publiczności, bo cena najmu fiakra jednokonnego mniejszą będzie ${ }^{14}$.

Tak pojawienie się jednokonnych dorożek komentował Ambroży Grabowski, historyk, antykwariusz, badacz dziejów Krakowa. Uwaga ta oddaje ówczesne podejście do koni - przedmiotowo-numeryczne. Koń jawił się jedynie jako środek do zarabiania pieniędzy, a odpowiednie nim zarządzanie pozwalało pomnażać zyski. Częścią Ustawy dla pojazdów publicznych w Krakowie $e^{15}$, przyjętej w 1873 roku, był rozdział poświęcony dorożkom. Ustawa precyzyjnie określała zasady funkcjonowania tych pojazdów w mieście. Oprócz wyszczególnienia ogólnych reguł poruszania się po ulicach zwracano także uwagę na obowiązki woźniców, precyzując sposób kontaktu z gośćmi. Litera prawa zakazywała dorożkarzom pozostawiania pojazdu bez nadzoru, palenia w czasie jazdy, grubiańskiego zachowania czy pijaństwa na postoju, jak również urządzania sobie na ulicach wyścigów. Nakazywano im jednocześnie spokojne i przyzwoite zachowanie oraz pozostawanie do dyspozycji gościa w ramach wynagrodzenia za usługę. We wspomnianej ustawie słowo „koń” pojawiło się raz - w kontekście należytego utrzymania pojazdu i higieny pracy. Ustawodawcy, wspominając o tych zwierzętach, mieli przede wszystkim na względzie zapobieganie zanieczyszczaniu i tamowaniu ulic. W tym celu zakazywano karmienia ich podczas oczekiwania na gościa, a w trakcie popasania nakazywano zakładanie im szczelnie worków na głowy; zakazywano karmienia sieczką, tak by chodniki pozostały czyste ${ }^{16}$.

Na początku XX wieku w Krakowie rozróżniano dwie kategorie dorożek: „gumowe” i „żelazne". Te pierwsze utrzymywane były starannie oraz zaprzęgano do nich dobre konie; z kolei „żelazne”, bez gum na kołach, należały do pojazdów mniej eleganckich i pracowały przy nich tak zwane gorsze konie. Istniało także rozróżnienie woźniców odpowiadające tym dwóm kategoriom. Lepszym dorożkarzom wyznaczano stanowiska na Rynku Głównym, a pozostałym wskazywano miejsca w bocznych uliczkach i na przedmieściach, tym samym skazując ich na mniej liczną klientelę. Ta dysproporcja była powodem licznych protestów i konfliktów pomiędzy dwiema grupami dorożkarzy ${ }^{17}$.

Konieczność zmiany stosunku do koni głosiły powstające od początku XIX wieku w Europie i Stanach Zjednoczonych towarzystwa opieki nad zwierzętami. Pierwszą tego typu organizacją na ziemiach polskich było Towarzystwo Opieki nad Zwierzętami (TOZ) założone w Warszawie w 1864 roku $^{18}$ jako oddział rosyjskiego Towarzystwa Opieki nad Zwierzętami. W 1875 roku powstał krakowski oddział tego Towarzystwa wraz z dodatkowym oddziałem w Tarnowie. Rozwiązanie przeszczepione z zaboru rosyjskiego nie wzbudziło w Krakowie entuzjazmu, a lokalny ruch na rzecz ochrony zwierząt nabrał rozpędu dopiero z chwilą powstania Krakowskiego Stowarzyszenia Ochrony Zwierząt, które było filią lwowskiego Towarzystwa. Zostało ono zawiązane 22 stycznia 1877 roku staraniem rodowitego krakowianina, geografa i przyrodnika, Bronisława Gustawicza ${ }^{19}$.

Pierwsze walne zebranie odbyło się 17 czerwca 1877 roku. Udział w nim wzięło dwadzieścia pięć osób. Wgroniezałożycielskimznalazł się równieżdr Michał Schmidt ${ }^{20}$, prawnik, starszyradca krakowskiego magistratu, który objął stanowisko prezesa. Jego zastępcą został dr Fryderyk Zoll21, 
profesor i rektor Uniwersytetu Jagiellońskiego, wspomniany Bronisław Gustawicz zajął stanowisko sekretarza i zarazem skarbnika, a jego zastępcą został Walery Eljasz-Radzikowski²2, artysta malarz ${ }^{23}$. Liczba nowych członków stale rosła i do końca roku było ich już 81, a w roku następnym 141. Wszyscy działacze mieli świadomość, że praca na rzecz ochrony praw zwierząt to przedsięwzięcie szeroko zakrojone, dotyczące wielu płaszczyzn i różnych grup społecznych. Szczególnie istotne były: większe zaangażowanie władzy, praca u podstaw z ludnością miasteczek i wsi, uświadamianie dzieci w szkołach, a zarazem uświadomienie sobie samemu, że występowanie przeciwko zwierzętom jest wielką skazą na charakterze każdego człowieka. Niemal od chwili powstania oddział ukierunkował swoją działalność na nieustanne zwiększanie liczby człon-

Idq̨c tropem raportów policyjnych, można z powodzeniem odtworzyć na mapie Krakowa „czarne punkty”, czyli miejsca, które były scenq najliczniejszych rejestrowanych nadużyć.

ków, nawiązanie stosunków z zagranicznymi towarzystwami, a przede wszystkim na ochronę zwierząt żyjących w mieście. Poza tym zwrócono się do Rady Szkolnej w mieście, ażeby zachęciła nauczycieli do przystępowania do Stowarzyszenia albo przynajmniej do prenumerowania w szkołach jego miesięcznika. Już na początku swojej działalności, 26 września 1878 roku, oddział przedstawił odezwę Konsystorzowi Biskupiemu w Krakowie z prośbą, by polecił duchowieństwu wspieranie celów założycielskich organizacji przez polecenie księżom w parafiach nieustannego pouczania ludu o konieczności humanitarnego traktowania zwierząt. Zwrócono się również do głównego rabina krakowskiego Szymona Schreibera, by w swoich naukach pouczał ludność żydowską o konieczności łagodnego obchodzenia się ze zwierzętami²4. Już pierwsze lata funkcjonowania Stowarzyszenia zarysowały główne kierunki jego działalności na przyszłość. Utworzona w 1877 roku organizacja istniała trzy lata, do 1880 roku, jednak potrzeba dalszej pracy na rzecz zwierząt była w Krakowie tak silna, że w 1887 roku doszło do powtórnego założenia Stowarzyszenia. Walne zgromadzenie w celu ukonstytuowania go odbyło się 13 marca tego roku. Jako szczególnego gościa zaproszono malarza Juliusza Kossaka ${ }^{25}$, który przewodził zgromadzeniu. Przewodniczącym reaktywowanej organizacji został adwokat dr Józef Mochnacki, jego zastępcą Hugo John, a sekretarzem nadal był Bronisław Gustawicz. Siedziba Stowarzyszenia mieściła się w kamienicy przy ulicy Podzamcze 3, tak jak redakcja wydawanego przez nie miesięcznika „Opiekun Zwierząt Domowych i Pożytecznych".

Spośród zwierząt żyjących w mieście dużą troską i przejęciem napawały członków Stowarzyszenia konie. Tak duże zainteresowanie ich dolą wiązało się ze skalą odnotowywanych nadużyć wobec nich. W 1879 roku, w okresie od stycznia do września, za dręczenie zwierząt krakowska policja ukarała 47 osób, z tego aż 39 za wykroczenia wobec koni - bicie i nadmierne obciążanie ${ }^{26}$. Być może duże wyczulenie policjantów na nadużycia wobec koni łączyło się również z charakterem miejsc, w których do takich zajść dochodziło. Były to najczęściej kluczowe punkty w topografii miasta: ulice w centrum, reprezentacyjne place oraz ulice, uczęszczane przez mieszczan i mieszczki wrażliwe na wszelakie okropieństwa. Idąc tropem raportów policyjnych, można z powodzeniem odtworzyć na mapie Krakowa „czarne punkty”, czyli miejsca, które były sceną najliczniejszych rejestrowanych nadużyć.

Jednym z takich miejsc był brzeg wiślany - podstawowe miejsce przeładunkowe w mieście, gdzie towar z galarów przepakowywano na wozy, a następnie transportowano dalej. 16 sierpnia 1879 roku Krakowskie Stowarzyszenie Ochrony Zwierząt zwróciło się ze specjalną odezwą do C.K. Dyrekcji Policji, informując o szczególnym dręczeniu koni przy przeładunku węgla z galarów na wozy na zwierzynieckim brzegu Wisły. Tam woźnice, pomimo stromego brzegu, zjeżdżali wozami na sam dół, co dla koni było ogromnie trudnym zadaniem. Kiedy zwierzęta nie radziły sobie z nadmierną stromizną, węglarze okładali je bezwzględnie batogami po brzuchu, głowie 
i chrapach. Jednocześnie Stowarzyszenie informowało, że do podobnych nadużyć dochodziło na brzegu Wisły w pobliżu kościoła Na Skałce, gdzie przy wybieraniu piasku konie grzęzły w błotnistym podłożu i nie mogły ruszyć z miejsca, co również ściągało na biedne zwierzęta agresję ze strony woźniców ${ }^{27}$.

Od kilku osób jednocześnie otrzymujemy zażalenie na nielitościwe obchodzenie się z końmi przez wywożących piasek z Wisły, obok rogatki Zwierzynieckiej. Przeładowawszy wóz wilgotnym piaskiem, do tego stopnia, że nędzne i wygłodzone stworzenia te, żadną miarą, ciężarowi podołać nie mogą, biją je i katują niemiłosiernie ${ }^{28}$.

Troszcząc się o byt koni w Krakowie, zarząd Stowarzyszenia 28 grudnia 1879 roku wniósł kolejną odezwę do Dyrekcji Policji. Wzorując się na zasadach obowiązujących w Warszawie i księstwie heskim, domagał się wydania odpowiednich zakazów oraz nakazów, które dotąd w Krakowie nie obowiązywały, a które doprecyzowałyby kwestię wykroczeń przeciw koniom. W złożonym projekcie zakazywano przeładowywania końskich wozów ciężarami oraz szybkiej jazdy z dużym obciążeniem zarówno pod górę, jak i z góry czy po równej drodze. Dodatkowo zakazywano woźnicy lub komukolwiek innemu siadania na wozie obładowanym - powinien iść pieszo obok koni. Prośba została przez Dyrekcję Policji rozpatrzona pomyślnie i stosowne rozporządzenie weszło w życie ${ }^{29}$.

Kolejny problem będący przyczyną cierpień zwierząt wiązał się z zakolem Wisły u stóp Wawelu. Chodziło o sprawę przeprawy promowej, kursującej stamtąd do tak zwanego dębnickiego cypla na drugim brzegu rzeki. Bolączką był tu brak stalowej liny, która zapewniłaby stabilność promu, a zarazem stałe miejsca przybijania i odbijania. Ze względu na ten brak prom za każdym razem przybijał w sposób losowy i raz wysadzał ludzi wraz z furmankami na głębokim i grząskim piasku, a innym razem na stromym urwisku. To zmuszało zwierzęta do ogromnego wysiłku ${ }^{30}$.

Ponieważ ten stan dojazdu, a zwłaszcza wyjazdu z promu od strony Dębnik jest stanem barbarzyńskiego nadużycia siły pociągowej zwierzęcej, bo koń zmuszony do ciągnienia nad siły w piasku na kilkanaście cali głębokim musi być poszkodowanym na zdrowiu i ponieważ taki stan rzeczy daje woźnicom powód do niemiłosiernego znęcania się nad końmi ${ }^{31}$.

Mając na uwadze ogólnie złą sytuację koni w mieście, zarząd Stowarzyszenia Ochrony Zwierząt skierował do Wysokiego C.K. Namiestnictwa projekt szczegółowego rozporządzenia. Postulowano wprowadzenie zakazu zaprzęgania i używania do jakichkolwiek robót źrebiąt przed ukończeniem czwartego roku życia. Zakazywano przeciążania koni, zwłaszcza tak zwanych zarobniczych. Domagano się bezwzględnego zakazu ich katowania, zaprzęgania do pracy zwierząt poranionych, chorych czy też zabiedzonych. W projekcie znalazły się też nakazy, by konie używane w miastach były prawidłowo podkute, a niepodkutych koni wiejskich by do miasta przez rogatki nie wpuszczano. Konie dorożkarzy i fiakrów stojące na postojach oraz wszystkie konie stojące przez dłuższy czas na targowiskach powinny być w porze zimowej i deszczowej przykryte derkami lub kocami. Dodatkowo wozy drążkarzy ${ }^{32}$, piaskarzy, ceglarzy i innych przedsiębiorców zarabiających dzięki koniom miały być w miastach opatrzone wielkimi oraz wyraźnymi numerami. Zwracano też uwagę na gabaryt wozu, na przykład do wozu załadowanego jednym stosem czterometrowym nakazywano zaprzęgnięcie przynajmniej trzech silnych koni ${ }^{33}$. Projekt ten, choć przedstawiony władzom, nie został przez nie przyjęty do realizacji. Z takim rozwojem wydarzeń liczyli się działacze Stowarzyszenia już w momencie składania projektu. Przywoływali wówczas analogiczną sytuację z Lwowa, gdzie w 1876 roku tamtejsi działacze wystosowali podobną prośbę o zaostrzenie i doprecyzowanie obowiązujących przepisów. W odpowiedzi usłyszeli od władz C.K. Namiestnictwa, że w tej materii rozporządzenie ministerialne obowiązujące od 1855 roku jest wystarczające ${ }^{34}$.

Członkowie Stowarzyszenia nie tylko skupiali się na piętnowaniu nadużyć wobec koni, lecz także starali się propagować wśród ludności nowinki techniczne, jak na przykład podkowy 


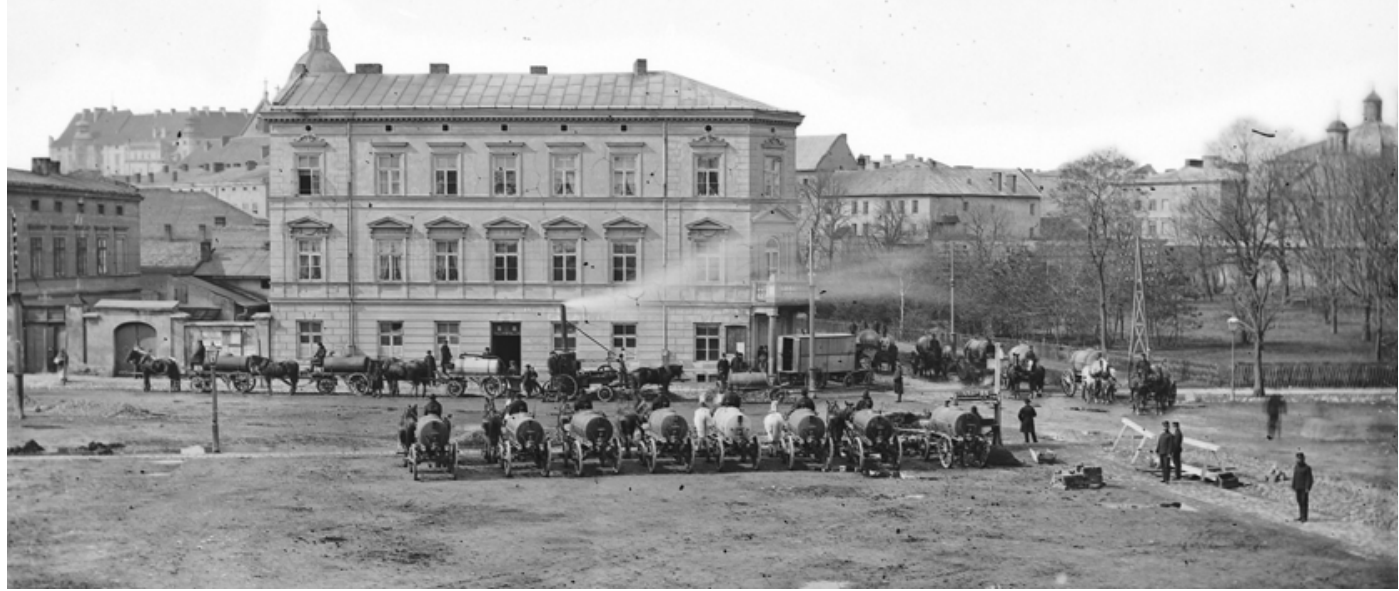

Tabor oczyszczania kanałów, około 1887 roku. Fot. Ignacy Krieger ŹRÓDŁO: ZE ZBIORÓW MUZEUM HISTORII KRAKOWA, NR INW. MHK-5481/K

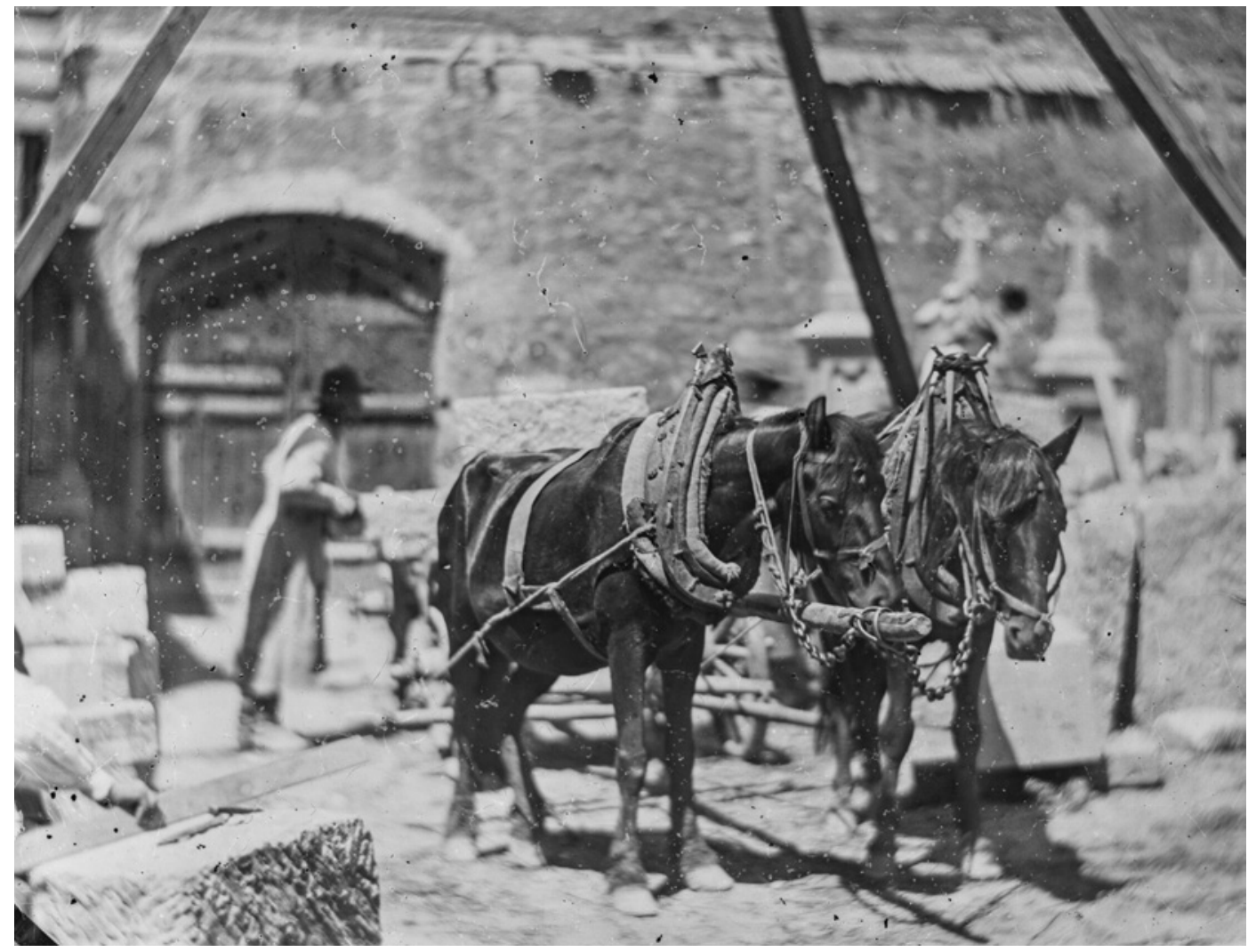

Zakład kamieniarski Fabiana Hochstima - konie przy pracy, przed 1878 rokiem. Fot. Ignacy Krieger ŹRÓDŁO: ZE ZBIORÓW MUZEUM HISTORII KRAKOWA, NR INW. MHK-6781/K 


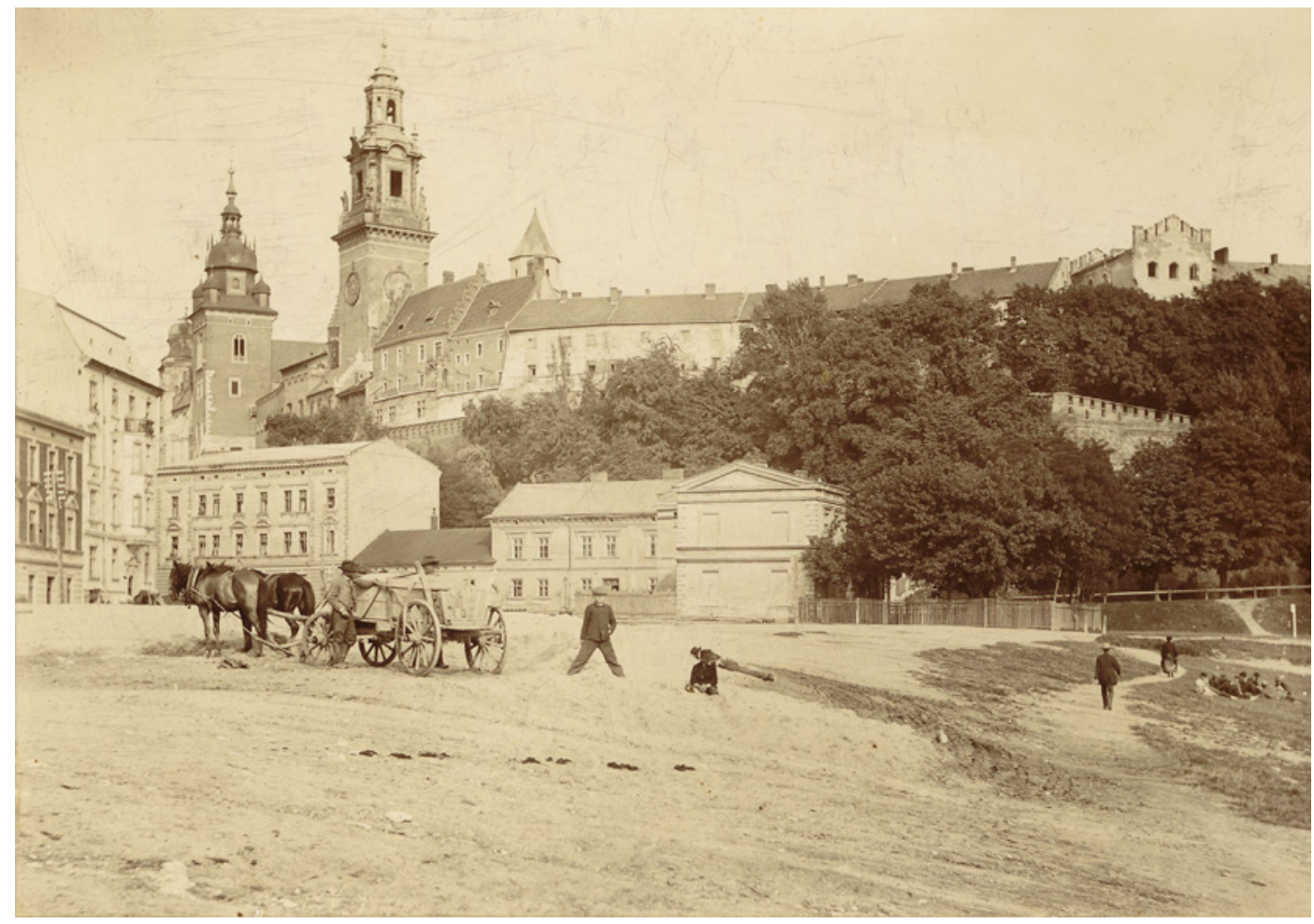

Zakole Wisły pod Wawelem, woźnica oczekujący na brzegu, po 1906 roku. Autor fot. nieznany ŻRóDto: ZE ZBIORÓW MUZEUM HISTORII KRAKOWA, NR INW. MHK-FS17909/IX

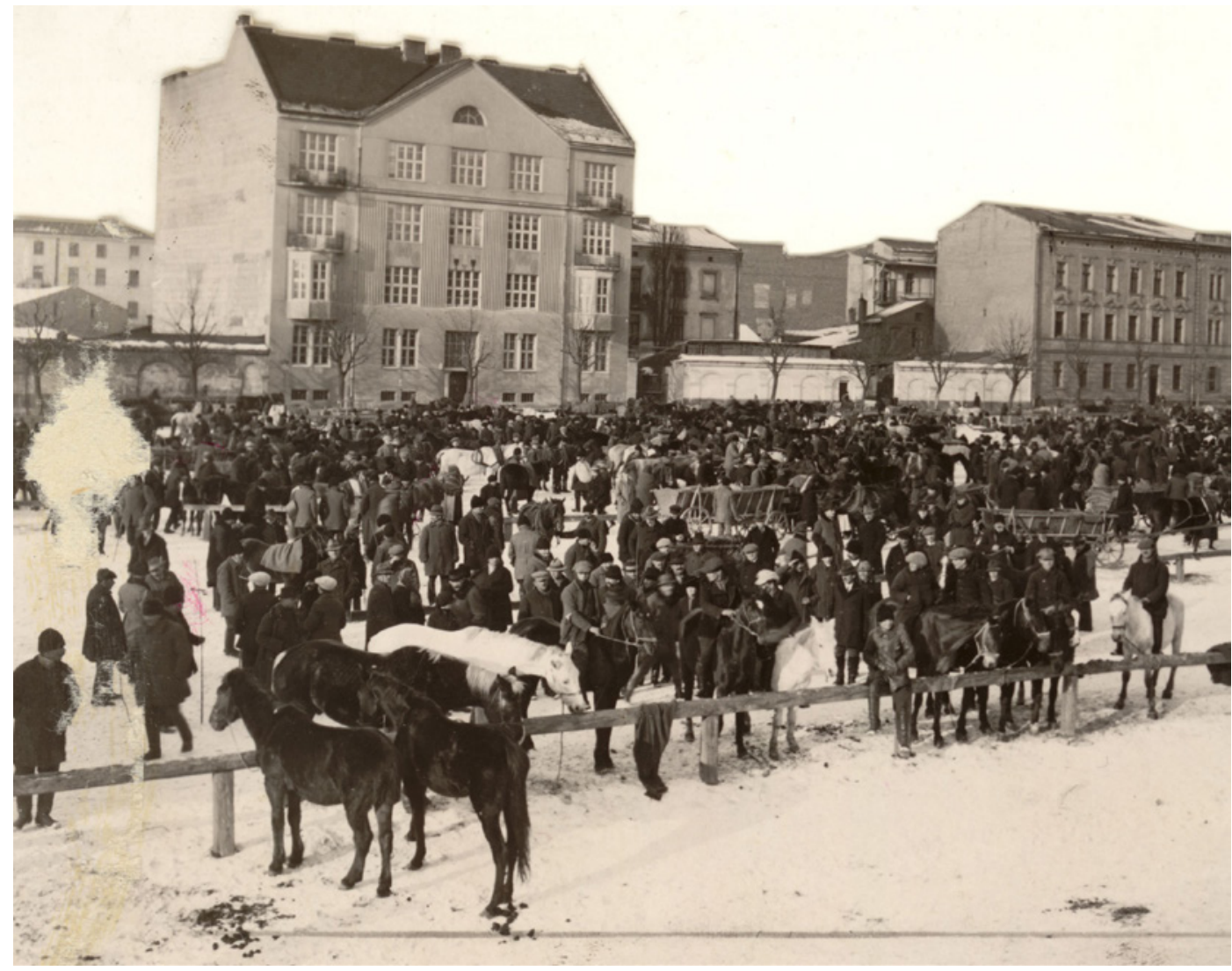

Targ koński na placu Na Groblach, około 1925 roku. Agencja Fotograficzna „Światowid" Ż́ÓDłO: ZE ZBIORÓW MUZEUM HISTORII KRAKOWA, NR INW. MHK-FS6566/IX 
gutaperkowe, które - wykonywane z elastycznego materiału - miały formę końskiego trzewika nakładanego po uprzednim rozgrzaniu na podkowę. Ich zaletą było to, że ochraniały końskie ścięgna, amortyzując stąpanie po twardej nawierzchni i bruku, a jednocześnie umożliwiały swobodny ruch kopyta ${ }^{35}$. Tego rodzaju udogodnienia dla koni prezentowano jako zagraniczne pomysły, które powinny zostać przeniesione na grunt polski; do sprzedawania i rozprowadzania tego typu podków jednak nie dochodziło. Mimo to mówienie o takich przedmiotach pełniło zapewne ważną funkcję uwrażliwiania na los zwierząt i wskazywało możliwe metody dbania o ich dobrostan w mieście.

Niezaprzeczalnie sceną najpoważniejszych nadużyć wobec tych zwierząt był targ koński przy placu Na Groblach. Tam nadzór policyjny nie był wystarczający. Mając to wszystko na uwadze, Stowarzyszenie przedstawiło 23 października 1887 roku w Prezydium Magistratu odezwę, w której sugerowało przeniesienie końskiego targu w inne miejsce, położone dalej od centrum miasta. Chodziło o wybranie miejsca swobodniejszego, w otoczeniu łąk i pastwisk, z nieograniczonym dostępem oraz przestrzenią, które zastąpiłoby dotychczasowy plac, wciśnięty pomiędzy zwartą zabudowę miejską. Żądano ustawienia na terenie placu targowego drewnianych barier z żelaznymi pierścieniami, tak aby konie mogły być do nich przywiązane szeregiem, co pozwalałoby na zachowanie większych odstępów pomiędzy zwierzętami, a zarazem zapobiegałoby ich ściskowi i wzajemnej agresji. Dodatkowo miały zostać wytyczone dwie aleje: jedna do ujeżdżania koni w zaprzęgu, a druga do ujeżdżania ich pod wierzch. Taka organizacja ruchu na targowicy miała ograniczyć chaos, przepychanie i przeciskanie się zwierząt oraz ich siłowe przepędzanie. Lepsza organizacja przestrzeni na placu targowym miała zapewnić spokój i większy porządek, co z kolei usprawniłoby kontrolę nad tym, co się tam działo.

Działacze Stowarzyszenia Ochrony Zwierząt nie pozostawili bez komentarza także sytuacji koni na wszelkiego rodzaju budowach, gdzie były one nadmiernie eksploatowane przy transporcie. Aby zwrócić uwagę władz miasta na to zagadnienie, zarząd składał do magistratu kolejne prośby, w których apelował, by policjanci pracujący w komisariatach w różnych częściach miasta zachowali czujność wobec furmanów mogących katować konie na budowach; postulował również, by osoby pilnujące placów budowlanych miały na uwadze warunki, w jakich te zwierzęta pracują. Upraszano o wykładanie deskami miejsc szczególnie grząskich i błotnistych, przez które trudno było im przejść.

Trudna dola koni w Krakowie była wyjątkowo komentowana również przed powstaniem w mieście filii warszawskiego Towarzystwa Opieki nad Zwierzętami - czyli pierwszej tego typu organizacji w tym mieście:

Już niejednokrotnie podnoszono w Krakowie myśl założenia towarzystw ochrony zwierząt. Zanim to jednak nastąpi, zanim nie będzie wolno nosić drobiu i cieląt za nogi związane, albo chudych szkap u wozów żydowskich okładać kijami, zalecamy tymczasem baczność władzy miejscowej konie dorożkarskie na rynku w dwóch miejscach stacje mające, to jest i parokonnych, i jednokonnych dorożek. Nie dziwmy się, że dorożkarzom siedzącym bezczynnie po parę godzin na koźle nudzi się, zwłaszcza gdy nie mają w zwyczaju, jak to bywa gdzie indziej, trudnić się lekturą; lecz żeby tych nudów nie przerywali nielitościwym smaganiem koni. Nieraz można bowiem słyszeć i widzieć, jak przestawszy bić w takt nogami lub biczyskami po skórze dorożek, biją potem w takt biczami po skórze swoje biedne konie - a pewnie nie swoje konie, lecz konie właścicieli dorożek. Szczególnie dorożkarze jednokonni używają tych gimnastycznych ćwiczeń, które prawdziwym są ćwiczeniem. Takie dręczenie zwierząt powinno być, jako czyn niemoralny, surowo karanym ${ }^{36}$.

Mając świadomość szczególnie trudnej sytuacji koni dorożkarskich, Krakowskie Stowarzyszenie Ochrony Zwierząt zaprosiło do członkostwa właścicieli dorożek, powozów i omnibusów. Miało to oczywiście służyć wprost ich uświadamianiu, a przez to wpływać na poprawę bytu zwierzą ${ }^{37}$. Ciekawym zabiegiem była próba wzbudzenia w mieszkańcach Krakowa współczucia dla koni przez symboliczne oddawanie głosu samym zwierzętom, tj. wydanie drukiem i rozprowadzanie wśród krakowian tak zwanej Prośby konia: 
Przyroda stworzyła mnie dla twego użytku, lecz powierzyła mnie twojemu miłosierdziu. Wszystkie moje usiłowania skierowane są ku temu, aby ci służyć i wypełniać twoją wolę. A więc nie czyń mnie nieszczęśliwym przez okrutne ze mną postępowanie. Nie braknie mi własnego rozumu i pojęcia, umiem być wdzięcznym i posłusznym, tylko mówić nie umiem. Często przejmuje mnie trwoga, ponieważ nie mogę zrozumieć, czego ode mnie wymagasz. Usiłuję pojąć twe chęci, ale mi się w głowie kręci od bolesnych razów, spadających mi na łeb i na chrapy, albo też odurzają mnie uderzenia grubych twoich biczysk i batów, często jeszcze uzbrojonych stalowymi kolcami, po moich bokach, a całe moje ciało jest zbolałe od ciągłego smagania batem. Dziąsła i usta moje bolą mnie od twardego wędzidła, które zawsze za mocno przyciągasz. Chomąto ściska mi szyję i tamuje oddech, albo kark mi tłucze i powoduje głębokie do kości sięgające rany, w których gnieżdżą się utrapione owady. Kuleję, bo mi twój kowal wbił ostry gwóźdź aż do żywego mięsa. Niepodobna mi po ośm godzin dziennie pędzić lub dźwigać ciężary po twardej, kamienistej lub błotnistej drodze, pod skwarem słonecznym lub podczas mroźnego wiatru. Zdałeś mnie na ręce stajennego lub fornala, który o mnie zapomina, a sam idzie do karczmy. Zgłodniały, spragniony, zbolały i zmęczony wracam wreszcie do domu, a tu nie dają mi ani wody, ani zdrowego i obfitego pokarmu, ani podściółki; mówią mi, że owies drogi, że siano wymokło na deszczach, że słomą trzeba bydło karmić; prawda! ale praca moja warta daleko więcej, a zarobiłbym dla ciebie dwa razy tyle, gdybyś mi owsa, siana i podściółki nie skąpił i dobrze się ze mną obchodził. Gniewasz się na mnie, żem bezsilny i niedołężny; zbywasz mnie za marne pieniądze nowemu tyranowi, który postanawia na śmierć mnie zamęczyć, lżysz mnie, nazywając szkapą, i martwisz się, że podług twego zdania stałem się dla ciebie przyczyną straty, a nie chcesz wiedzieć tego, że gdybyś mnie pielęgnował, dobrze żywił i obchodził się ze mną, jak należy, pracowałbym gorliwie z korzyścią dla ciebie, a w razie gdybyś mnie sprzedawał, przyniósłbym ci znaczne zyski ${ }^{38}$.

Tekst ten był próbą uwrażliwienia człowieka na los zwierzęcia przez postawienie go w pozycji partnera w rozmowie. Koń zwraca się do człowieka w typowo ludzki sposób, nawiązuje do odczuć, tłumaczy swoje emocje, akcentując jednocześnie własną zwierzęcą naturę, która uniemożliwia pewne działania - między innymi skuteczne komunikowanie potrzeb i skarżenie się na nadużycia. Również zakończenie stanowi odwołanie do ludzkiego sposobu postrzegania świata - przez pryzmat własnych zysków i korzyści. W punkcie wyjścia próbuje się poruszyć ludzkie sumienie przez nawoływanie do bycia miłosiernym, lecz zabieg ten równoważy pragmatyczne przypomnienie o potencjalnym braku zysku i stracie finansowej, będących skutkiem znęcania się nad koniem - zwierzęciem stanowiącym wówczas często podstawę zarobkowania. Jak zauważa Éric Baratay, takie też - ekonomiczne - były między innymi przyczyny wprowadzania profilaktyki i dbania o zdrowie koni, co szczególnie łatwo zauważyć na przykładzie wielkich przedsiębiorstw korzystających z siły tych zwierząt. Traktując konie jako rodzaj kapitału, uważano, że zwraca się on tylko wtedy, kiedy zwierzęta pracują ${ }^{39}$.

Głównym elementem egzystencji koni była ich codzienna praca na ulicach miasta, ona też stanowiła dla nich największe zagrożenie, a częste kontakty z ludźmi w relacji całkowitej zależności stwarzały mnóstwo okazji do nadużyć. Znaczenie tych zwierząt było jednak ogromne, stały się bowiem jednym z ogniw łańcucha postępu - doskonałym tego przykładem jest rozwój komunikacji, który dzięki koniom nabierał coraz większego tempa. Dzięki pracy koni rozwijała się dynamicznie komunikacja publiczna w znaczących miastach Europy. Nie inaczej było w Krakowie. Tutaj w 1875 roku wprowadzono pierwsze omnibusy konne kursujące od mostu Podgórskiego do dworca kolejowego przez Rynek Główny. Był to wstęp do dalszych działań w celu organizacji sieci tramwajowej. W 1881 roku organizacji tramwaju konnego podjęło się towarzystwo belgijskie (Société Génerale de Tramways). Pierwszą linię oddano do użytku w 1882 roku. Miała ona 2,8km długości, a przejazd całości trasy trwał osiemnaście minut. 31 października 1882 roku odbył się pierwszy uroczysty przejazd tramwaju konnego z Rynku Głównego do dworca kolejowego ${ }^{40}$. 
Podstawą funkcjonowania tego typu komunikacji były konie, które ciągnęły „wozowagony" po torowisku do złudzenia przypominającym współczesne. W chwili planowania budowy tramwaju konnego zakładano, że konieczne będzie utrzymanie ośmiu wagonów, które ze względu na płaskie ukształtowanie terenu w Krakowie mogły być ciągnięte przez jednego konia, przy trzykrotnym przeprzęganiu dziennie. Takie plany wymagały utrzymania trzydziestu koni oraz dziesięciu furmanów i trzech pomocników stajennych ${ }^{41}$. W rozbudowanej umowie dotyczącej organizacji tramwaju konnego w Krakowie, którą miasto podpisało z towarzystwem belgijskim, o koniach wspomniano jedynie w dwóch artykułach. W artykule XII określono, że wagony powinny dzielić się na dwie klasy, nie mogą być szersze niż 90 centymetrów i mają być ciągnięte przez jednego konia. W innym miejscu, w artykule XVII, zastrzegano, że w razie wynalezienia i rozpowszechnienia innych form siły pociągowej niż zwykła siła końska przedsiębiorstwo zobowiązane jest zastosować się do tego bezwzględnie ${ }^{42}$. W 1882 roku w taborze tramwajów konnych utrzymywano dwadzieścia pięć koni, którym zapewniano paszę, kucie, lekarstwa i sól; pokrywano również koszty wszelkich napraw rymarskich. Potwierdzają to szczegółowe pozycje w budżecie miejskim ${ }^{43}$. Tak jak i wcześniej, mimo działań Stowarzyszenia, obecność tych zwierząt na ulicach skutkowała nad wyraz pragmatycznym podejściem do nich. Już w 1883 roku zaczęto towarzystwu belgijskiemu zwracać uwagę, że wbrew pierwotnym ustaleniom wozy tramwajowe są często ciągnięte przez dwa konie, a nie przez jednego, co powoduje większe uszkodzenia bruków miejskich ${ }^{44}$. W ostatnim roku swojego istnienia tramwaje konne przejechały 370000 wozokilometrów ${ }^{45}$ i przewiozły 1700000 pasażerów, co przy stanie zaludnienia utrzymującego się na poziomie 70000 osób dawało dwadzieścia cztery jazdy rocznie na jednego mieszkańca ${ }^{46}$. Pierwsze tramwaje elektryczne wjechały na ulice Krakowa 16 marca 1901 roku ${ }^{47}$.

W Krakowie działania na rzecz ochrony praw zwierząt, w tym również koni, zapoczątkowane jeszcze w XIX wieku, zostały w pełni rozwinięte w okresie międzywojennym. Wówczas, w 1928 roku, działalność zainaugurował w tym mieście wojewódzki Związek Opieki nad Zwierzętami (ZOZ). Jego prezesem został inżynier kolejnictwa Karol Barwicz, a wiceprezesem dr Zdzisław Wawrausch, prawnik i radny miejski ${ }^{48}$. Jak czytamy w statucie Związku, jego celem miała być „oparta na uszlachetnianiu instynktów człowieka ochrona otaczającego nas świata zwierzęcego, ze szczególnym uwzględnieniem zwierząt pożytecznych, przeciw wszelkiego rodzaju dręczeniu zwierząt, nieludzkiemu ich traktowaniu i rozmyślnemu częstokroć prześladowaniu ze szkodą dla społeczeństwa i ujmą ludzkiej godności”"

Do czołowych działaczy krakowskiego ZOZ należeli nauczycielka muzyki i społeczniczka Kazimiera Treterowa oraz pisarz i aktor Zygmunt Nowakowski, który od 1933 roku pełnił funkcję prezesa Związku. W swoich przedsięwzięciach działacze ZOZ bardzo często sięgali do rozwiązań zaproponowanych jeszcze w XIX wieku przez Krakowskie Stowarzyszenie Ochrony Zwierząt. Działając w innych realiach, mogli im nadać większy rozgłos i dzięki temu zapewnić szerszy odbiór społeczny. Jednym z bardziej widocznych w przestrzeni miasta przedsięwzięć Związku był Dzień Dobroci dla Zwierząt, który po raz pierwszy odbył się 11 października 1936 roku. Punktem kulminacyjnym uroczystości był pochód propagandowy, który przeszedł głównymi ulicami miasta. Wśród idących w nim nie zabrakło głównych bohaterów tego dnia, czyli samych zwierząt. Ramię w ramię z ludźmi szły konie, psy, kozy, a nawet ptaki niesione na plecach w specjalnie skonstruowanych koszach ${ }^{50}$.

18 października 1932 roku ZOZ wprowadził jako pierwszy w kraju instytucję nadzwyczajnego inspektora, którego zadaniem było egzekwowanie przepisów prawnych dotyczących opieki nad zwierzętami. Do przestępstw podlegających karom 2000 złotych grzywny ${ }^{51}$ lub sześciu tygodni aresztu zaliczano między innymi wykorzystywanie do pracy zwierząt chorych, rannych, zaniedbywanie, bicie ich i nadmierne przeciążanie. O tym, że Związek aktywnie walczył z dręczeniem zwierząt, świadczą liczby. W samym 1930 roku odnotowano ponad 290 interwencji, $\mathrm{z}$ tego aż 177 dotyczyło koni ${ }^{52}$.

Ogromna liczba nadużyć wobec koni skłoniła Związek do zorganizowania osobnego wydarzenia poświęconego wyłącznie tym zwierzętom. Dzień Konia po raz pierwszy odbył się w Krakowie 14 października 1935 roku. Wspólnie z działaczami Związku w organizacji tego święta wzięli udział Małopolska Izba Rolnicza, Dowództwo Okręgu Korpusu oraz prezydent Krakowa, który wielokrotnie patronował działaniom na rzecz zwierząt. Ten dzień zainaugurowała msza święta w kościele oo. Kapucynów, a następnie ulicami miasta przejechała kolumna 
udekorowanych pojazdów i zaprzęgów. Drugą część dnia wypełniły popisy hippiczne na Błoniach, podczas których występowali głównie żołnierze kawalerii. Kolejnym wydarzeniem był konkurs na najlepiej utrzymanego konia dorożkarskiego i włościańskiego ${ }^{53}$. Co warte odnotowania, część komentatorów prasowych postrzegała ów dzień jako przedsięwzięcie zorganizowane przede wszystkim przez Izbę Rolniczą i wojsko, jedynie przy wsparciu Związku Opieki nad Zwierzętami. Jako uzasadnienie tego przedsięwzięcia podawano:

[...] podniesienie w oczach ogółu wartości konia w rolnictwie, przemyśle i komunikacji, jego roli w obronie kraju i pobudzenia serc ludzkich, często tak nieczułych dla konia w pracy.

Przy tej okazji w prasie lokalnej publikowano artykuły skupiające uwagę czytelników na naturze koni i sposobie postrzegania przez nie świata. Na przykład w zamieszczonym w „Ilustrowanym Kurierze Codziennym” tekście Czy zawsze rozumiemy konia (rozważania z okazji „DNIA KONIA") uwypuklono cechy zwierzęcia często poczytywane przez ludzi za oznakę głupoty, która z kolei miała usprawiedliwiać agresję. Między innymi wyjaśniono dużą płochliwość konia jego nie najlepszym wzrokiem, argumentowano też, że bat nigdy tego zwierzęcia nie przekona.

Jeżeli jednak przeceniamy zdolności konia czy innych zwierząt, to nie robimy im przez to żadnej krzywdy. Gdy jednak nie znając i nie mając pojęcia o życiu i potrzebach konia, chcemy biciem oduczyć go od jakiejś wady, nie tylko nie zmienimy jego postępowania, ale spaczymy całą jego naturę ${ }^{54}$

Mimo to Dzień Konia tak naprawdę stawiał w centrum obchodów ludzi i ich potrzeby - nie dbano choćby o komfort koni defilujących w tłumie ulicami Krakowa, udekorowanych szeleszczącymi, różnokolorowymi wstążkami i kwiatami.

Tekst jest szkicem przedstawiającym ewolucję w podejściu do koni, jaka zaszła na przełomie XIX i XX wieku w Krakowie, podobnie zresztą jak w innych miastach europejskich. Był to proces sprzęgnięty z narodzinami lokalnego ruchu na rzecz praw zwierząt, który w pewien sposób tę ewolucję na mieszkańcach miasta wymusił, jak i stopniowo uświadomił im konieczność zwrócenia uwagi na potrzeby zwierząt dzielących z nimi przestrzeń miejską. Z pewnością zmiana świadomości mieszkańców Krakowa była zjawiskiem długotrwałym oraz skomplikowanym, a przedmiotowe traktowanie koni bardzo często utrudniało myślenie o nich jako o istotach czujących i cierpiących z powodu człowieka.

\section{PRZYPISY}

1 P. Atkins, Animal Wastes and Nuisances in Nineteenth-Century London, w: P. Atkins (red.), Animal Cities. Beastly Urban Histories, Farhnam 2012. Fragmenty tej pracy w polskim tłumaczeniu w tym tomie, zob. Zwierzęce nieczystości i utrapienia w dziewiętnastowiecznym Londynie, przeł. J. Schollenberger.

2 C. McShane, J.A. Tarr, Horse in the City. Living Machines in the Nineteenth Century, Baltimore 2007, s. 1-2.

3 „Dziennik Rozporządzeń dla Stołecznego Miasta Krakowa” 1881, nr 9, s. 4.

4. „Przyjaciel Zwierząt" 1898, nr 1, s. 11.

5 H. Polańska, Konie w ruchu miejskim Warszawy XIX i w XX w. (do 1945 r.), w: M. Lisiewicz, A. Łysiak-Łąt kowska (red.), Jaki koń jest, nie każdy widzi: koń w polskiej kulturze miejskiej i wybranych tekstach piśmienniczych od antyku do współczesności, Gdańsk 2017, s. 23.

6 A. Gawryszewski, Ludność Warszawy w XX wieku, Warszawa 2009, s. 61

7 Statystyka Miasta Krakowa: zestawiona przez Biuro Statystyczne Miejskie, Kraków 1912, z. 12, s. 67.

8 C. Bąk-Koczarska, Juliusz Leo, twórca Wielkiego Krakowa, Kraków 1986.

9 Statystyka Miasta Krakowa..., dz. cyt., s. 66

10 Dla porównania wynagrodzenie dzienne czeladnika murarskiego wynosiło wówczas około 1 złotego reńskiego 9 koron. Za: J. Demel, Stosunki gospodarcze i społeczne Krakowa w latach 1853-1866, „Biblioteka 
Krakowska", nr 112, Wrocław 1958, s. 315. Kilogram najlepszych cukierków kosztował 2 złote reńskie, jedna fotografia z połyskiem formatu gabinetowego 1 złoty reński, a damskie buty skórkowe 6 złotych reńskich. Za: Józefa Czecha Kalendarz Krakowski na rok 1877, Kraków 1877.

11 J. Demel, Stosunki gospodarcze i społeczne Krakowa w latach 1846-1856, „Biblioteka Krakowska”, nr 107, Kraków 1951, s. 205

12 Tamże, s. 88. Liczba tych pojazdów na ulicach miasta sukcesywnie rosła, w 1880 roku, tuż przed wprowadzeniem na ulice Krakowa tramwaju konnego, wydano siedemnaście nowych koncesji na dorożki. Za: Dziennik Rozporządzeń dla Stołecznego Królewskiego Miasta Krakowa, Kraków 1880

13 J. Demel, Stosunki gospodarcze i społeczne Krakowa w latach 1846-1856..., dz. cyt., s. 131.

14 A. Grabowski, Wspomnienia Ambrożego Grabowskiego, „Biblioteka Krakowska”, nr 40, Kraków 1909, s. 311

15 Ustawa dla publicznych pojazdów w Krakowie, Kraków 1873.

16 Józefa Czecha Kalendarz Krakowski..., dz. cyt., s. 94-95

17 "Czas" 1913, nr 53, s. 2

18 Więcej na ten temat: A. Jaroszuk, Ludzie - zwierzęta - miasto. Warszawiacy i wybrane gatunki zwierzat w przestrzeni publicznej Warszawy w drugiej połowie XIX wieku i na poczatku wieku XX, praca magisterska na kierunku kulturoznawstwo - wiedza o kulturze napisana pod kierunkiem dr. hab. Pawła Rodaka, Instytut Kultury Polskiej Uniwersytetu Warszawskiego, Warszawa 2015, s. 18.

19 Z. Szromba, Gustawicz Bronisław, w: Polski słownik biograficzny, t. 9, Wrocław 1961, s. 174-175.

20 C. Bąk-Koczarska, Schmidt Michat, w: Polski słownik biograficzny, t. 35, Warszawa 1994, s. 547-548.

21 P.M. Żukowski, Zoll Fryderyk Franciszek, w: D. Malec (red.), Profesorowie Wydziału Prawa Uniwersytetu Jagiellońskiego, t. 2: 1780-2012, Kraków 2014, s. 599-601.

22 M. Grabski, Walery Eljasz Radzikowski - fotograf Tatr i Podhala, "Dagerotyp” 2005, nr 14, s. 14-29.

23 "Czas" 1877, nr 137, s. 3.

Sprawozdanie z czynności Krakowskiego Stowarzyszenia Ochrony Zwierzat za czas od 17 czerwca 1877 do 31 grudnia 1878 roku, Kraków 1879, Archiwum Narodowe w Krakowie (dalej ANK), sygn. ZOZ-2 s. 4-6.

25 A. Ryszkiewicz, Kossak Juliusz, w: Polski słownik biograficzny, t. 14, Wrocław 1969, s. 244-246.

26 „Przyjaciel Zwierząt” 1879, nr 7-8, s. 66

27 "Przyjaciel Zwierząt” 1880, nr 1-2, s. 7-8

28 "Kronika" 1875, nr 186, s. 3

29 "Przyjaciel Zwierząt" 1880, nr 1-2, s. 7-8.

30 Tamże, s. 9.

31 Tamże.

32 Drążkarzami nazywano woźniców wykorzystujących do pracy małe, jednokonne wozy - drążki, zwykle niekryte i nienumerowane; drążkarze często podbierali klientów dorożkarzom. Za: J.I. Kraszewski, Obrazy z życia i podróży, t. 1, Wilno 1842, s. 43.

33 "Przyjaciel Zwierząt” 1880, nr 1-2, s. 7-10.

34 Tamże, s. 11

35 „Przyjaciel Zwierząt” 1880, nr 3-4, s. 40

36 "Czas" 1865, nr 259, s. 3

37 Sprawozdanie z czynności Krakowskiego Stowarzyszenia Ochrony Zwierząt za czas od 17 czerwca 1877..., dz. cyt., s. 5.

38 "Opiekun Zwierząt Domowych i Pożytecznych” 1890, nr 3, s. 58-59.

39 É. Baratay, Zwierzęcy punkt widzenia. Inna wersja historii, przeł. P. Tarasewicz, Gdańsk 2014, s. 222.

40 "Czas" 1882, nr 249, s. 2

41 M. Moraczewski, Droga żelazna konna (tramway) w Krakowie. Sprawozdanie Urzędowe Dyrektora Budownictwa, Kraków 1891, s. 13

42 "Dziennik Rozporządzeń dla Stołecznego Miasta Krakowa” 1882, nr 5, s. 5.

43 "Dziennik Rozporządzeń dla Stołecznego Miasta Krakowa" 1882, nr 1, s. 7.

44 "Dziennik Rozporządzeń dla Stołecznego Miasta Krakowa” 1883, nr 8, s. 2. 
45 Wozokilometr to jednostka miary stosowana w transporcie kołowym; określa długość drogi wykonanej przez środki transportu (wozy) w określonym czasie.

46 T. Polaczek-Kornecki, Zarys monografii Komunikacji Wewnętrznej Komunikacji Miasta Krakowa. Opracowany z okazji XXII-go kongresu międzynarodowego dla spraw tramwajownictwa, kolejnictwa dojazdowego i komunikacji autobusowej w Warszawie w dniach od 29 czerwca do 6 lipca 1930 r., Kraków 1930, s. 7.

47 Tamże, s. 10.

48 J. Gellner, B. Sobucka, Jak pies z kotem. Katalog wystawy. Muzeum Historyczne Miasta Krakowa, Kamienica Hipolitów, Kraków 2016, s. 38-39.

49 Statut Związku Opieki nad Zwierzętami, Kraków 1932, AKN, sygn. ZOZ-1, s. 7-17.

50 Sprawozdanie z działalności Zarządu Głównego Związku Opieki nad Zwierzętami w Krakowie za rok administracyjny 1936, Kraków 1937, ANK, sygn. ZOZ-1, s. 637-746.

51 Dla porównania przeciętna pensja robotnika budowlanego w 1932 roku wynosiła około 220 złotych: Za: Mały Rocznik Statystyczny, Warszawa 1932, s. 98

52 Piękny rozwój Związku Opieki nad Zwierzętami, „Ilustrowany Kuryer Codzienny” 1939, nr 113, s. 10

53 "Czas" 1935, nr 283, s. 6

54 „Tempo Dnia" 1935, nr 283, s. 10. 


\section{Stephanie Weismann}

\section{Odorogenne zwierzęta w międzywojennym Lublinie}

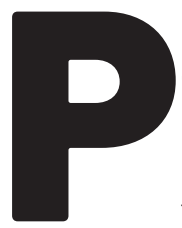

oruszając temat śmierdzących koni, agresywnych szczurów, hałaśliwych ptaków, cuchnących świń i rozkładającej się padliny, w artykule skupiam się na spotkaniach ludzko-zwierzęcych w międzywojennym Lublinie, z położeniem nacisku na kontakty zmysłowe, zwłaszcza zaś angażujące zmysł węchu. Śledząc proces wyostrzania się powonienia wśród tamtejszych mieszkańców, przedstawiam historię miejskich wysiłków modernizacyjnych, a więc również dezodoryzacyjnych. Debaty dotyczące zapachów, w tym pochodzenia zwierzęcego, były częścią szerszej dyskusji o kształtowaniu się nowoczesnych miast w Drugiej Rzeczypospolitej.

Zapoczątkowany w latach 90. wzrost zainteresowania sensoryczną percepcją świata w naukach społecznych i humanistycznych skłonił wielu badaczy do społecznej oraz kulturowej analizy ludzkiego sensorium ${ }^{1}$. Miejski „zmysłobraz” stał się w ostatnich latach ważnym tematem². „Zapachobrazy” (smellscapes) ${ }^{3}$ miast były dotychczas badane ze szczególnym uwzględnieniem kwestii architektonicznych, socjologicznych i geograficznych ${ }^{4}$. Mimo to perspektywę historii zmysłów rzadko odnoszono do Europy Środkowo-Wschodniej ${ }^{5}$ i prawie nigdy do studiów nad zwierzętami (animal studies) ${ }^{6}$, chociaż umożliwia ona wgląd w problematykę związaną z rozwojem miast oraz (emocjonalną) dynamikę relacji ludzko-zwierzęcych.

Zapachy odgrywają znaczącą rolę w codziennym doświadczaniu miasta. Miejskie „zapachobrazy" - zapachy specyficzne dla środowiska miejskiego - są skomponowane z wielu różnych elementów. Choć ich charakter i intensywność w mieście są warunkowane przez różne czynniki, takie jak stopień uprzemysłowienia, praktyki sanitarne, zwyczaje kulinarne, pora roku czy rodzaj zabudowy, to największe znaczenie mają sami mieszkańcy, tak ludzcy, jak zwierzęcy $^{8}$. Jako że zmysł powonienia odgrywa ważną rolę w codziennym życiu, badanie miejskich „zapachobrazów” pozwala zilustrować nie tylko ekonomiczne czy ekologiczne, lecz także społeczno-kulturowe przemiany zachodzące w obrębie poszczególnych ośrodków miejskich ${ }^{9}$. Innymi słowy, szukając odpowiedzi na pytania, „co śmierdzi”, „kto śmierdzi” albo „co k o mu śmierdzi”, możemy zarówno określić „obiektywne” warunki środowiskowe, jak i opisać różne rodzaje wrażliwości kształtowane przez czynniki społeczne oraz kulturowe.

Na uwagę zasługuje fakt, że to właśnie zmysł węchu jako pierwszy skłonił urbanistów i reformatorów społecznych z XVIII stulecia ${ }^{10}$ do zainteresowania się wyziewami więzień oraz szpitali. Z kolei wyczuwając wiele różnorodnych odcieni zapachu zgnilizny występującego w miejskim 
otoczeniu, rozwinęli oni rodzaj „wrażliwości zapachowej”. „Rewolucja olfaktoryczna”"11 jaka dokonała się w XIX wieku, wskazuje na gwałtowny spadek tolerancji wobec nieprzyjemnych zapachów, będący konsekwencją rozwoju nowoczesnej świadomości zagrożeń zdrowotnych i związanych z nimi problemów społecznych właściwych rozrastającym się miastom. Wszystkie najważniejsze projekty urbanizacyjne z połowy XIX wieku związane z rozwojem wielkich metropolii, jak na przykład przebudowa Paryża podjęta przez Georges’a Haussmanna, reorganizacja Londynu według planów Josepha Bazalgette'a czy też plan zagospodarowania przestrzennego Berlina przygotowany przez Jamesa Hobrechta, kładą nacisk na kwestie zapewnienia świeżego powietrza oraz budowy kanalizacji. Istotne było tu również przeniesienie zainteresowania z biologicznych aspektów zapachów na ich wymiar społeczny, co w konsekwencji przyniosło dążenie do kontrolowania nie tylko organicznych wyziewów, lecz także „moralnych wysięków” miejskich konglomeratów ${ }^{12}$.

Ten rodzaj wzmożonej „czujności zapachowej” związany z wielkimi zmianami społeczno-politycznymi i przemianami życia miejskiego można obserwować w różnych historycznych epokach, w różnych momentach dziejów ${ }^{13}$ - także w międzywojennej Polsce, która jest tutaj przedmiotem zainteresowania. Ponieważ perswazyjną i niewidzialną obecność zapachów trudno uregulować ${ }^{14}$, stały się one ważnym problemem w procesie poddawania nowoczesnego miasta kontroli, jego strukturyzowania i dyscyplinowania. Przyglądając się z bliska zarówno walce władz Lublina z organicznymi odorami, jak i domaganiu się przez mieszkańców dostępu do świeżego powietrza, analizuję, co było przedmiotem polityki miejskiej w Drugiej Rzeczypospolitej i jakie miejsce zajmowały w niej zwierzęta.

Lublin traktuję tutaj jako studium przypadku ukazujące ogólną sytuację średniego miasta w Europie Środkowo-Wschodniej w pierwszej połowie XX wieku - oraz oplatające je dyskursy. Historia lubelskich warunków urbanistycznych i wrażliwości mieszkańców nie jest w żaden sposób wyjątkowa. Jest świadectwem raczej trudnych, chociaż zwyczajnych wyzwań oraz zmieniającego się urbanistycznego i społeczno-politycznego krajobrazu miasta w Europie Środkowo-Wschodniej.

Źródła odnoszące się do zwierząt w Lublinie pochodzą zarówno z międzywojennej prasy lokalnej, jak i podań, skarg czy raportów wysyłanych przez lublinian do władz miasta, zwłaszcza do Wydziału Zdrowia. Oddają one powszechne utrapienia i pokazują związane ze smrodem problemy tamtego czasu.

\section{Obecność zwierząt i zapachy odzwierzęce}

Najliczniejszymi i najbardziej widocznymi zwierzętami na ulicach Lublina w okresie międzywojennym były z pewnością konie. Używano ich od dawna w komunikacji zbiorowej i w transporcie dóbr, stanowiły więc codzienny widok ${ }^{15}$. Głównym zapachem na ulicach tego miasta był wówczas smród końskiego łajna, co potwierdzają liczne źródła. Tu dwa przykłady spośród wielu odnalezionych w archiwach:

[W Lublinie] panuje wszechwładnie brud i fetor pochodzący z końskich „wypocin” [...]; wokół postojów dorożek panuje dziś nieopisany wprost „zapach”, który trzeba najszybciej usunąć ${ }^{16}$.

Dozorcy, by przyśpieszyć tajanie śniegu, rozrzucają ten śnieg na wpół zmieszany z gnojem na jezdnię. Można sobie wyobrazić, jakie „miłe wonie” panują na ulicy, gdy zacznie się parowanie rozrzuconego „gnoju-śniegu”. Przecież tego rodzaju załatwianie sprawy nie nadaje się nie tylko do z górą stutysięcznego Lublina, lecz nawet do Bełżyc czy do innej Psiej Wólki. Sprawę usuwania śniegu należy nareszcie raz unormować. Zatruwanie powietrza na ulicach powinno się natychmiast skończyćc ${ }^{17}$.

Postoje dorożek często znajdowały się przy hotelach, restauracjach i kawiarniach w samym sercu miasta, gdzie eleganckie pary, młodzież oraz rodziny spacerowały w czasie wolnym. Jeszcze w 1921 roku w Lublinie żyły setki koni oraz tysiące krów i świñ ${ }^{18}$, nie wspominając 
o wszystkich zwierzętach ciągnących furmanki zjeżdżające do miasta na targ. Trzymanie i hodowanie zwierząt oraz ich bliskość, wraz z brudem i smrodem, były częścią codziennego życia w dużych miastach europejskich aż do pierwszych lat XX wieku ${ }^{19}$. Zwierzęta były źródłem pożywienia i nawozu, środkiem transportu oraz surowcem dla produkcji przemysłowej. Stanowiły także niezbędny element „łańcucha pokarmowego” i zarazem gospodarki odpadami organicznymi - resztki jedzenia powszechnie wykorzystywano jako pokarm dla świń. Miasto i otaczające je przestrzenie wiejskie były od siebie ściśle zależne: wieś żyła dzięki miastu i na odwrót, wymieniając jedzenie na nawóz w ramach wypracowanego modelu krążenia materii. Ta cyrkulacja nie byłaby możliwa bez udziału zwierząt.

Z czasem jednak ich obecność zaczęła przeszkadzać miejskim nosom. Rosła liczba skarg dotyczących trzymania zwierząt w mieście. Dyscyplinowanie zwierzęcego, organicznego, łączonego z zacofaniem „zapachobrazu” w przestrzeni miejskiej było kluczową kwestią dla Lublina w okresie międzywojennym. Uchwalony w 1919 roku regulamin Zarządu Miejskiego zakazywał trzymania zwierząt hodowlanych (ptaków, świń, kóz) w przestrzeniach mieszkalnych, między innymi w salonach ${ }^{20}$. Na podwórkach jednak nadal panował swoisty „zapachobraz”, na który składały się wonie różnych cieczy pochodzących ze zwierzęcych odchodów, z warsztatów, małych rzeźni, szamb i rynsztoków. Wraz z postępem urbanizacji także te nieprzyjemne zapachy które dotychczas były powszechnym elementem życia nie tylko wsi, lecz także miast europejskich - coraz bardziej dokuczały mieszkańcom.

Urząd miasta coraz częściej wzywał do zachowania higieny, więc rosła i świadomość higieniczna: mieszkańcy Lublina wyraźniej zgłaszali potrzebę oddychania świeżym powietrzem. Tymczasem park miejski, będący w zamierzeniu „rezerwuarem świeżego powietrza” i miejscem spokojnej rekreacji, był krytykowany za obecność głośnych ptaków pozostawiających swoje odchody. W „Głosie Lubelskim” ostrzegano: „[...] mieszkańcy będą musieli słuchać wrzasków czarnego ptactwa [...]; ptactwo zanieczyszcza ławki, aleje i trawniki, a nawet ubrania przechodniów"21. Sedno problemu codziennych spotkań ludzko-zwierzęcych leżało w bliskości fizycznej oraz zmysłowej: smród końskiego łajna i uryny zmuszający ludzi do zatykania nosa ${ }^{22}$; szczury podchodzące do ludzi, o czym pisano w prasie: „Szczury [n]ocą [...] po chodnikach Krak[owskiego] Przed[mieścia] spacerują masowo [...]; jest ich tak mnóstwo, że ważą się zbliżać do ludzi [...]."23; przestrzenie odpoczynku oraz świeżego powietrza zakłócane przez głośne ptaki i ich odchody. W prasie zwracano także uwagę na obecność martwych zwierząt: „[...] w staw wrzuca się zdechłe psy i koty, wylewa się pomyje i brudy. Już na moście trzeba zatykać nos, taki trupi odór bije z bagniska"24.

Zwierzęta miały znaczący wpływ na miejski krajobraz i „zapachobraz” nawet po śmierci. Działało wówczas w Lublinie wiele drobnych przedsiębiorstw miejskich, często mieszczących się w podwórkach, zajmujących się przetwarzaniem zwierzęcych zwłok na skóry, mydło oraz świece, co było procesem związanym z wytwarzaniem nieprzyjemnych zapachów i produkcją odpadów. Na podwórkach równie często trzymano zwierzęta hodowlane. To jednak też zaczęło przeszkadzać. W latach 20. i 30. sąsiedzi takich hodowli protestowali już przeciwko brzydkim zapachom, które docierały do ich mieszkań: „[...] lokator [...] zrobi sobie chlew po gołem niebem i cały smród i gnojówka wychodzi, że nie można w mieszkaniu wytrzymać z tego smrodu [...]"25. Przykry zapach, którego źródłem były odpady pochodzenia zwierzęcego, nie ograniczał się więc do przestrzeni publicznej, lecz wyraźnie ingerował w prywatną.

\section{Niezdrowe miazmaty vs. dyskurs sanitarny}

Historie miast europejskich wskazują, że niektóre gatunki, takie jak konie służące do transportu albo zwierzęta hodowlane trzymane na podwórkach, były od dawna tolerowane w codziennym życiu miejskim ${ }^{26}$. Jednak w kontekście ożywionej debaty o zdrowiu publicznym toczącej się w XIX i na początku XX wieku w Europie pewne zwierzęta zaczęto łączyć z rozprzestrzenianiem się chorób ${ }^{27}$. Teoria miazmatyczna, która dominowała w dyskusjach o zdrowiu do końca XIX wieku, widziała w „złym powietrzu” wydostającym się z gnijącej materii organicznej główne źródło epidemii. Odchody ludzkie i zwierzęce napiętnowano w niej szczególnie mocno. Teoria ta, upowszechniana w licznych raportach oraz artykułach prasowych, przyczyniła się do wytworzenia nowej świadomości społecznej i w pewnym momencie doprowadziła do „kryzysu 
fekalnego”. „Wielki smród” Paryża i Londynu z połowy XIX wieku doprowadził do zasadniczych interwencji infrastrukturalnych, $w$ tym do budowy nowych systemów kanalizacyjnych.

W przypadku Lublina podobne procesy urbanizacyjne polegające na modernizacji, higienizacji i w związku z tym dezodoryzacji przestrzeni miejskiej zaszły w dekadach następujących po odzyskaniu przez Polskę niepodległości w 1918 roku: chociaż teoria miazmatyczna została już wyparta przez teorię Pasteura o chorobotwórczej roli zarazków, odory wciąż uznawano za zagrożenie dla zdrowia. W kontekście utworzenia „Wielkiego Lublina” - o czym w szczegółach piszę niżej -zapachy tego rodzaju postrzegano też jako zagrożenie dla nowoczesności rozumianej jako próba opanowania nie tylko morowego powietrza, lecz także ludzi oraz ich zachowań przez publiczne nakazy i zakazy ${ }^{28}$. Po odzyskaniu przez Polskę niepodległości władze miasta równocześnie z wieloma innymi miastami w byłym zaborze rosyjskim rozpoczęły realizację dużego projektu sanitarnego ${ }^{29}$. Lublin, wcześniej sprowadzony do roli prowincjonalnego miasta na peryferiach Imperium Rosyjskiego, w 1918 roku został stolicą województwa w centrum Drugiej Rzeczypospolitej i w związku z tym podjęto w nim próbę gruntownej modernizacji polegającej w dużej mierze na jego higienizacji i dezodoryzacji.

Zarówno [...] władze, jak i mieszkańcy zostali więc zaangażowani w definiowanie tego, co miejskie, a także określanie, co jest i co nie jest na swoim miejscu w nowoczesnym mieście - dotyczyło to między innymi zwierzęcych zapachów. Brud, śmieci i „kłopotliwe” zwierzęta stały się katalizatorami przyjęcia teorii sanitarnych, ale też negocjacji dotyczących tego, co tworzy „nowoczesne” miasto. Zarówno jego władze, jak i mieszkańcy zostali więc zaangażowani w definiowanie tego, co miejskie, a także określanie, co jest i co nie jest na swoim miejscu w nowoczesnym mieście - dotyczyło to między innymi zwierzęcych zapachów. Postrzeganie zwierząt jako czynnika zakłócającego porządek częściowo wynikało z ich cech "naturalnych”, związanych ze smrodem, z gnojem i pasożytami. Sąsiedztwo zwierząt oraz ludzi było coraz częściej krytykowane jako niewłaściwy model życia miejskiego i odbierane jako zagrożenie dla zdrowia.

Przytoczone wyżej cytaty wskazują, że w międzywojennym Lublinie kontakty jego mieszkańców ze zwierzętami zapośredniczone przez zmysły w dużej mierze były kształtowane przez takie kategorie jak smród, kał i rozkład. Te organiczne zapachy stopniowo zaczęto uważać za coraz większy problem w kontekście miejskim. Zarządzanie miejskimi zapachami stało się zasadniczym elementem kształtowania nowoczesnej miejskości. Smród rozkładu zaczynał być rozumiany jako antyteza nowoczesnego miasta, które miało być uporządkowane i higieniczne, a natura w nim ujarzmiona oraz zdyscyplinowana ${ }^{30}$. W tworzonej od nowa Drugiej Rzeczypospolitej również Lublin miał być oczyszczony z odpadów i gnoju ${ }^{31}$. Brud, kał i ich zapachy organiczne były coraz częściej postrzegane jako coś „, nie na swoim miejscu”32 - niejednoznaczne, anormalne, niepokojące.

Służba zdrowia - w tym komisje sanitarne miejskich magistratów - już w Królestwie Polskim z różną skutecznością próbowała ustanowić standardy higieny, warunków sanitarnych i zwalczania epidemii ${ }^{33}$. W okresie międzywojennym lubelski zarząd miejski regularnie publikował regulaminy porządkowe ${ }^{34}$ zawierające informacje o zasadach i obowiązkach związanych z utrzymaniem higieny. Umieszczano tam instrukcje, jak powinny wyglądać higienicznie uporządkowane podwórza, „zlewy”, „ustępy”, jak poprawnie utrzymywać czystość wewnątrz nieruchomości, jakie wiążą się z tym obowiązki właścicieli, administratorów i dozorców, jakie są obowiązki mieszkańców, jakie wreszcie są sankcje karne za naruszenie tych zasad. Surowo zakazywano zanieczyszczania klatek schodowych, podwórek, chodników, ulic oraz placów śmieciami, odpadami kuchennymi, plwocinami i odchodami. Te przepisy dają wgląd w bieżące pilne problemy sanitarne charakterystyczne dla Lublina, ale też dla wielu ówczesnych europejskich 


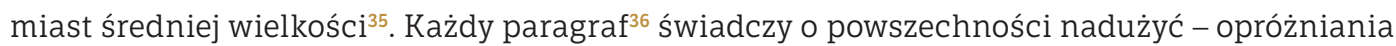
nocników nad chodnikiem, podwórek zaśmieconych różnego rodzaju (cuchnącymi) odpadami i plucia, gdzie popadnie.

Lubelska Komisja Sanitarna - część Wydziału Zdrowia - angażowała się w walkę ze smrodem przez przeprowadzanie inspekcji czystości ulic, budynków, sklepów spożywczych i podwórek w celu kontroli zapachów oraz zarządzania nimi. Lokalne gazety wypełniały się listami adresowymi osób, które miały ponieść odpowiedzialność za „niechlujność i przekroczenie przepisów sanitarnych" ${ }^{{ }^{37}}$. Te publiczne donosy nie przynosiły jednak znaczących rezultatów - przykre „zapachobrazy” niezmiennie wypełniały przestrzeń Lublina w pierwszej połowie XX wieku. Tymczasem dyskurs dotyczący porządku, higieny i dezodoryzacji na przełomie lat 20. i 30. znacznie się rozszerzył.

\section{Sen o pachnącej nowoczesności w „Wielkim Lublinie”}

W 1925 roku Towarzystwo Urbanistów Polskich ogłosiło planowany od 1919 roku konkurs urbanistyczny poświęcony „Wielkiemu Lublinowi”, który wpisywał się w ogólnopolskie, a nawet ogólnoeuropejskie trendy reformatorskie w kwestii rozwoju miejskiego i systemu sanitarnego ${ }^{38}$, a także stanowił próbę zachęcenia do intensywnej urbanizacji, szczególnie ważnej na terenie byłego zaboru rosyjskiego. Kierownik Wydziału Budowlanego Zarządu Miasta Lublin Ignacy Kędzierski zakładał, że Lublin ma zostać poddany „procesowi cywilizacyjnemu”. Pisał o potrzebie „zhigienizowania, uregulowania, uporządkowania, polepszenia” Lublina w celu uczynienia go "nowoczesnym miastem" o "charakterze reprezentacyjnym” 39 . Pomiędzy 1925 a 1929 rokiem miał zostać radykalnie zrestrukturyzowany i zmodernizowany. Ponieważ urbaniści od dawna skupiali się na kontroli smrodu oraz zarządzaniu nim, projekty higienizacji i dezodoryzacji przeprowadzane przez władze miasta w ramach „Wielkiego Lublina” - dzięki pożyczkom ulenowskim ${ }^{40}$ - dotyczyły głównie ścieków, regulacji wywozu śmieci, brukowania ulic, a także wzmocnienia koryt rzek w taki sposób, aby umożliwić większy przepływ wody, eliminując wody stojące ${ }^{41}$. Regulowanie odorów (za pomocą kanalizacji, asenizacji i zarządzania miejską rzeźnią - tzn. przenoszenia szczególnie intensywnie pachnących zakładów wytwórczych poza miasto) - było kluczowym działaniem urbanizacyjnym ${ }^{42}$. W miastach ciągle zmagających się z epidemicznymi skutkami I wojny światowej zdrowie publiczne stało się kluczowym proble$\mathrm{mem}^{43}$. Wydziały zdrowia zaczęły być bardzo ważnym graczem w międzywojennej polityce polskiej oraz w politykach miejskich.

Niepokoje związane ze „złym powietrzem” i wciąż krążące widmo miazmatów podgrzewały dyskusje o zwierzętach i zwierzęcych odchodach w przestrzeniach do życia oraz do pracy. Narodziny idei higienicznych doprowadziły do "wielkiego oddzielenia” (albo przynajmniej dyskusji o nim) ludzkich przestrzeni mieszkalnych od przestrzeni zwierzęco-produkcyjnych $^{44}$. „Wielkie oddzielenie” zakładało niedopasowanie „miejskości” i „nowoczesności” oraz tego, co „wiejskie” i świadczące o „zacofaniu”. Jak pisze Peter Atkins, „Wielkie oddzielenie nie było zachodzącą z dnia na dzień rewolucją, lecz stanowiło powolny proces, który w zależności od miasta miał różne tempo i charakteryzował się różnym stopniem kompletności zmian”45. Lublin tego czasu stanowi przykład wiejskiego społeczeństwa w procesie przemian. Zwłaszcza pomiędzy rokiem 1914 a 1931 można zaobserwować duży napływ zubożałych ludzi z okolicznych wsi, którzy przybywali do miasta w poszukiwaniu pracy. W kontekście nowego regulowania miasta od roku 1925 wiejska przeszłość mieszkańców Lublina i bliskość zwierząt hodowlanych nie przystawały do idei oczyszczonego oraz odzwierzęconego „nowoczesnego” miasta Drugiej Rzeczypospolitej. Uchwycenie stosunku do zwierząt daje wgląd w ówczesne rozumienie kategorii „miejskości”"46. Higiena miasta i walka z organicznymi odorami stanowiły przedmiot zainteresowania lubelskiego magistratu już od drugiej połowy XIX wieku ${ }^{47}$, jednak dopiero w pierwszej dekadzie Drugiej Rzeczypospolitej przekształcanie Lublina w przestrzeń „czystą”, „ustrukturyzowaną”, „niecuchnącą” stało się kluczową kwestią nie tylko dla władz, lecz także w dyskusjach i świadomości publicznej. Po trudnym okresie zaborów regulowanie miejskich wyziewów było ważną próbą nadania polskim miastom reprezentacyjnego i nowoczesnego wyglądu. W „Ziemi Lubelskiej” można było przeczytać: „Lublin, stolica województwa, 
posiadający teatry, towarzystwa kulturalne, uniwersytet i kupy gnoju na ulicach: Czy można sobie coś takiego wyobrazić w Warszawie, Lwowie, Krakowie? W Lublinie, tak. Rynny i zlewy, którymi wycieka na ulice wszelki brud domowy, [Lublin] obłożony jest gnojem [...]"48. Będący dawniej częścią Królestwa Kongresowego Lublin próbował dogonić inne duże polskie miasta z odmiennymi doświadczeniami urbanizacji pod pruską i habsburską władzą. W tym doganianiu chciał także zapewnić dostęp do świeżego powietrza miejskiego i spełnić standardy nowoczesnego miasta niepodległej Polski ${ }^{49}$.

\section{Odraza węchowa jako forma ogłady}

Skutkiem ubocznym wzrostu świadomości wymogów zdrowotnych i higienicznych była nowa wrażliwość węchowa. Na przełomie lat 20. i 30. XX wieku można zaobserwować nie tylko wzmożenie działań dezodoryzacyjnych prowadzonych przez władze miasta, lecz także wyłonienie się kultury skarg na zapachy publikowanych na łamach gazet lub kierowanych do Wydziału Zdrowia. Te podania, prośby i zażalenia ${ }^{50}$ dotyczące przykrych zapachów miejskich oraz zanieczyszczenia powietrza częściowo były skutkiem wspomnianych wyżej miejskich przedsięwzięć sanitarnych. Jednak zwiększona czujność zapachowa, wywołana publicznym dyskursem sanitarnym, również świadczy o nowej świadomości obywatelskiej. Wstręt i odraza (a więc także uwrażliwienie zmysłów na „wiejskość” w obszarze miejskim) zaczęły być widziane jako forma ogłady ${ }^{51}$ świeżo ustanowionego obywatela Drugiej Rzeczypospolitej, w szczególności mieszkańca miasta. Napływ kierowanych do instytucji publicznych skarg na niedogodności może być rozumiany jako fenomen związany z procesem demokratyzacji i kształtowania obywatela po odzyskaniu niepodległości - jako forma korzystania z praw obywatelskich ${ }^{52}$.

Proces usuwania nieczystości i ich oddzielenie jest - jak pokazałam - cechą nowoczesności ${ }^{53}$. Nowo wyłoniona wrażliwość węchowa była jednym z czynników rekonfiguracji miejsca zwierząt w mieście. Rosnąca liczba skarg mieszkańców Lublina dotycząca problemu hodowli zwierząt na miejskich podwórkach świadczy, że zwierzęta i związane z nimi zakłady przestały być postrzegane jako „miejskie”. Sięgnijmy do źródeł:

Niniejszem zawiadamiam Wydział Sanitarny, że M.B. [...] trzyma u siebie 3 krowy i kilka świń. Wiadomo, że trzymanie bydła i nierogacizny w Śródmieściu, w nieodpowiednich drewnianych budynkach, jest niedozwolone ze względów higienicznych i zdrowotnych, lecz M.B. drwi sobie z podobnych przepisów [...]; lecz w dodatku jeszcze zdechłe świnie zakopuje w swym ogrodzie (trzeba wspomnieć, że w ostatnich tygodniach świnie zdychają [...] dość często). Z powodu niemiłych zapachów wydzielających się z obory i chlewu oraz wstrętnych much niemożliwością jest siedzieć w ogrodzie sąsiadującym [...]; również niemożliwością jest otwieranie okien w celu przewietrzania mieszkania ${ }^{54}$.

Gdy zwierzęta przekraczały nowo ustalone granice rozumienia miejskiej nowoczesności, było to uznawane za zanieczyszczenie ${ }^{55}$ lub dewiację ${ }^{56}$. Uderzające jest, że ludzie, coraz częściej odnosząc się do higieny i zdrowia, domagali się „świeżego powietrza”:

Melduję do Wydziału Zdrowia Publicznego, że [...] dozorczyni tegoż domu stale hoduje świnie. Otóż w ubiegłym roku [...] Komisja Wydziału Zdrowia surowo nakazała świnie usunąć, a jednak to nie pomogło. Tylko do obecnej chwili świnie są, i to w chlewie drewnianym, i do tego dozorczyni specjalnie zrobiła kilka otworów, żeby świnie miały powietrze. [...] stale w mieszkaniach mamy pełno smrodu, który trudno znieść [...], prosimy uprzejmie o zaopiekowanie się tym cuchnącym podwórzem i o usunięcie tego tak niemiłego powietrza, które wprost zabija człowieka ${ }^{57}$.

W walce o czyste lub świeże powietrze chodziło zawsze o powietrze pozbawione organicznych, zwłaszcza zwierzęcych, zapachów: 


\begin{abstract}
Szanowny Panie Doktorze!
Proszę i błagam o litość p. Doktora nad biedną kobietą, którą jestem tak nieszczęśliwą i cierpi stale na silny ból głowy, i wszelkie zanieczyszczone powietrze mi bardzo szkodzi. Ponieważ jestem w tak krytycznym rozpołożeniu [sic!], że nie mogę sobie nawet proszków kupić, żeby swemu cierpieniu ulżyć, więc chciałabym, żeby chociaż [...] to powietrze ze dworu było trochę czyściej [...], a jednak i tego trudno, bo właśnie w tym domu [...] dozorczyni [...] choduje [sic!] 2 duże świnie i stale chlew na oścież jest otwarty [...], więc jeszcze raz proszę szanowanego p. Doktora o rozpatrzenie mojej prośby [...], żeby chociaż chlew był zamykany, żebym mogła przynajmniej oddychać choć trochę czyściejszym powietrzem [...] $]^{58}$.
\end{abstract}

Skargi te pokazują nowe rozumienie tego, jakie zapachy były do zaakceptowania, a jakie już nie, i w ten sposób zaświadczają o nowo nabytej lub podwyższonej wrażliwości węchowej. Zapachy, również zwierzęce, służyły jako narzędzie odróżniania tego, co „nowoczesne”, od tego, co „wsteczne”, tego, co miejskie, od tego, co wiejskie. Nowoczesny miejski obywatel rozwinął w sobie świadomość, co to znaczy być „mieszkańcem miasta”. Skarżąc się na odory wytwarzane przez zwierzęta (konie przy dorożkach lub świnie na podwórku), mieszkańcy określali, czym miejskie powietrze powinno pachnieć, a czym nie. „Wielki Lublin” wyobrażony w konkursie urbanistycznym miał być wolny od organicznego smrodu gnoju.

Zalecenia związane z higieną publiczną, częste apele w prasie codziennej i działania Komisji Sanitarnej podnosiły w Lublinie świadomość znaczenia regulacji w tej dziedzinie oraz koncepcji zdrowia publicznego, a także indywidualnego samopoczucia. Ponadto wspomniany wyżej konkurs urbanistyczny był istotną sprawą publiczną. Pierwszy raz kwestia rozwoju miasta stała się tematem szeroko zakrojonej debaty ${ }^{59}$. Podejście elit do kwestii sanitarnych w mieście i do niepodległości narodu spotkały się z rosnącymi obawami mieszkańców dotyczącymi własnego zdrowia i przestrzeni prywatnej (oraz prywatnego powietrza). Ta nowa definicja tego, co jest akceptowalne, a co nie, również wywołała wzrost zaangażowania obywatelskiego. Przytoczone powyżej skargi, odnoszące się do istniejących już dawniej zapachów, odbieranych jednak zgodnie z nową wrażliwością, były w oczywisty sposób konsekwencją nowej świadomości obywatelskiej. Nowy obywatel miasta domagał się prawa do świeżego powietrza i otwartych okien, miasta bez końskiego łajna na ulicach i bez śmierdzących kur oraz świń na podwórkach. Cytowane wyżej skargi pokazują, jak w nowy sposób rozumiano „dobre miasto”, lecz także kim jest dobry obywatel - korzysta on z praw obywatelskich i ma wyrafinowany nos.

Co ciekawe, smrody nowoczesności, takie jak wyziewy sektora przemysłowego czy później spaliny produkowane przez rosnącą liczbę samochodów, rzadko były odbierane jako zapachowa uciążliwość przez ludzi z pierwszej połowy XX wieku. Mieszkańcom Lublina śmierdziało przede wszystkim to, co organiczne - co potwierdza szersze zjawisko znacznie większej akceptacji dla zapachów przemysłowych, kojarzonych z postępem ${ }^{60}$.

Przełożyła Sara Herczyńska

\title{
PRZYPISY
}

1 A. Corbin, We władzy wstrętu: społeczna historia poznania przez węch: od odrazy do snu ekologicznego przeł. A. Siemek, Warszawa 1998; D. Howes, The Varieties of Sensory Experience: A Sourcebook in the Anthropology of the Senses, Toronto 1991; C. Classen, Worlds of Sense: Exploring the Senses in History and across Cultures, New York 1993; P. Rodaway, Sensuous Geographies: Body, Sense and Place, London-New York 1994; J. Douglas Porteous, Smellscape, "Progress in Physical Geography" 1985, nr 9(3); C. Classen, Aroma. The Cultural History of Smell, London-New York 1994

2 Zob. J. Urry, City Life and the Senses, w: G. Bridge, S. Watson (red.), A Companion to the City, Oxford 2008, s. 388-397; I. Illich, The Dirt of Cities, the Aura of Cities, the Smell of the Dead, and Utopia of an Odourless City, w: M. Miles, T. Hall, I. Borden (red.), The City Cultures Reader, London 2000; M. Zardini, W. Schivelbusch, Sense of the City: An Alternate Approach to Urbanism, Montréal 2005; K. DeFazio, The City of the Senses: Urban Culture and Urban Space, New York 2011.

3 J. Douglas Porteous, Smellscape, w: J. Drobnick (red.), The Smell Culture Reader, Oxford-New York 2006 [1985]. 
4 A. Corbin, We władzy wstrętu..., dz. cyt.; P. Payer, Der Gestank von Wien. Über Kanalgase, Totendünste und andere üble Geruchskulissen. Wien 1997: N. Poiret, Odeurs impures. Du corps humain à la cité (Grénoble, XVIIle-XIXe Siècle), "Terrain. Anthropologie et Sciences Humaines" 1998, nr 31, s. 89-102; W. Bischoff, Ein Hauch von Großstadt - Überlegungen zum urbanen Geruchsraum, w: J. Hasse (red.), Subjektivität in der Stadtforschung, Frankfurt/M. 2002, s. 41-60; E. Cohen, The Broken Cycle. Smell in a Bangkok Soi/Lane, "Ethnos" 1998, t. 53, nr 1-2, s. 37-49; M.F. Manalansan, Immigrant Lives and the Politics of Olfaction in the Global City, w: J. Drobnick (red.), The Smell Culture..., dz. cyt., s. 41-52; K.E.Y. Low, Presenting the Self, the Social Body, and the Olfactory: Managing Smells in Everyday Life Experience, "Sociological Perspectives" 2006, t. 49, nr 4 s. 607-631; V. Lapin, Peterburg: zapakhy i zvuki, Sankt Petersburg 2007; A.M. Martin, Sewage and the City: Filth, Smell, and Representations of Urban Life in Moscow, 1770-1880, "The Russian Review" 2008, t. 67, nr 2 , s. 243-274; V. Henshaw, Urban Smellscpapes. Understanding and Designing City Smell Environments, New York 2013; N. Kenny, The Feel of the City: Experiences of Urban Transformation, Toronto 2014; A. Mack, Sensing Chicago: Noisemakers, Strikebreakers, and Muckrakers, Urbana, IL 2015; M. Diaconu, L.M. Vosicky, Gerüche des öffentlichen Raums zwischen Raumcharakteren und Sozialpraktiken, w: M. Diaconu, G. Buchbauer, J.G. Skone, K.-G. Bernhardt, E. Menasse-Wiesbauer (red.), Sensorisches Labor Wien. Urbane Haptik- und Geruchsforschung, Wien 2011; J. Drobnick, Volatile Effects: Olfactory Dimensions of Art and Architecture, w: D. Howes (red.), Empire of the Senses. The Sensual Culture Reader, Oxford-New York 2005.

5 Z paroma wyjątkami, zob. M.P. Romaniello, T. Starks, Russian History through the Senses: From 1700 to the Present, London-New York 2016: O. Vaynshteyn, Aromaty i zapachy v kul'ture, t. 2, Moskwa 2010: M. Pirogovskaya, Odour of Chlorine in Soviet Urban Reality: Notes on the Clean and the Collective, w: R. Beck, U. Krampl, E. Retaillaud-Bajac (red.), Les Cinq Sens De La Ville Du Moyen Âge À Nos Jours, Tours 2013, s. 199-210; M. Pirogovskaya, Miazmy, simptomy, uliki: zapakhi mezhdu meditsinoj i moralju v russkoj kul'ture vtoroj poloviny XIX veka, Sankt Petersburg 2018. Zob. również projekty badawcze Jana Plampera i Igora Narskiego na temat rewolucji październikowej z perspektywy historii zmysłów i emocji, a także badania Bodo Mrozka dotyczące zapachowej historii podziału Niemiec w XX wieku.

6 Wyjątek stanowi praca P. Atkinsa (red.), Animal Cities. Beastly Urban Histories, Farnham 2012. Fragmenty tej pracy w polskim tłumaczeniu w tym tomie, zob. Zwierzęce nieczystości i utrapienia $w$ dziewiętnastowiecznym Londynie, przeł. J. Schollenberger.

7 Zob. J. Douglas Porteous, Smellscape, „Progress in Physical Geography” 1985, t. 9, s. 356-378; P. Rodaway, Sensuous Geographies..., dz. cyt.

8 J. Drobnick, Toposmia: Art, Scent, and Interrogations of Spatiality, "Angelaki: Journal of Theoretical Humanities" 2002, nr 1, s. 33.

2 Zob. A. Synnott, The Body Social: Symbolism, Self, and Society, London-New York 1993; G.P. Largey and D. Rodney Watson, The Sociology of Odors, "American Journal of Sociology” 77, no. 6 (1972).

10 J. Urry, City Life..., dz. cyt., s. 393-395

11 O "rewolucji olfaktorycznej" i marzeniu dziewiętnastowiecznych higienistów, by ludzkie środowisko poddać dezodoryzacji, pisze Alain Corbin, We władzy wstrętu..., dz. cyt., s. 78-84, 177

12 Zob. tamże, jak również G. Simmel, Soziologie Der Sinne, t. 11, Frankfurt am Main 1992 [Essai sur la sociologie des sens 1912]. Dla Simmela życie społeczne jest doświadczeniem sensorycznym. Analizował on zmieniające się znaczenie zmysłów węchu, słuchu i wzroku w nowoczesnym życiu, w szczególności w życiu miejskim. Zobserwował, że różnice zapachowe współtworzą podziały rasowe i klasowe.

13 Zob. A. Corbin, We władzy wstrętu..., dz. cyt., jak również A. Martin, Sewage and the City: Filth, Smell, and Representations of Urban Life in Moscow, 1779-1880, "The Russian Review" 2008, nr 67; C. Neidhart, Russia's Carnival: The Smells, Sights, and Sounds of Transition (Maryland: Rowman and Littlefield, 2003).

14 J. Urry, City Life..., dz. cyt., s. 393.

15 Na temat roli koni w miastach europejskich zob. G. Bouchet, Le Cheval à Paris de 1850 à 1914, Genève-Paris 1993; C. McShane, J. Tarr, The Horse in the City: Living Machines in the Nineteenth Century, Baltimore 2007.

16 „Ziemia Lubelska”, 3.09.1930, s. 4.

17 „Ziemia Lubelska”, 6.01.1931, s. 3.

18 H. Gawarecki, O dawnym Lublinie. Szkic z przeszłości miasta, Lublin 1974, s. 226

19 P. Atkins, Animal Wastes and Nuisances in Nineteenth-Century London, w: P. Atkins (red.), Animal Cities. Beastly Urban Histories, dz. cyt., s. 37; H. Velten, Beastly London: A History of Animals in the City (London 2013), rozdz. Livestock. Londoners' Nuisance Neighbours, s. 13-42, oraz Working Animals. Straining Every Muscle, s. $43-86$.

20 J. Gebhard, Lublin. Eine Polnische Stadt Im Hinterhof Der Moderne (1815-1914), Köln-Weimar-Wien 2006.

21 "Głos Lubelski", 30.04.1921, s. 3.

22 "Głos Lubelski”, 23.08.1924, s. 3. „Przykra woń unosząca się dookoła w dalszym ciągu przy każdym miejscu postoju dorożek świadczy wymownie o tym, jak prędko zapomina się u nas o czymś porządnym i dobrym. Przecież zarówno w zimie, jak i w lecie ludzie mają jednakowe nosy i jednakowy węch".

23 "Ziemia Lubelska", 24.07.1929, s. 3

24 "Ziemia Lubelska", 14.06.1928, s. 2

25 Porządki domowe i uliczne 1928-31 (Wydział Zdrowia), Archiwum Państwowe w Lublinie (APL), sygn. 352207.6.2.1.2557. 
26 Zob. P. Atkins, The Urban Blood and Guts Economy, w: tenże, Animal Cities..., dz. cyt., s. 98.

27 Tenże, Animal Wastes and Nuisances..., s. 27.

28 J. Reinarz, Past Scents: Historical Perspectives on Smell, Urbana, Chicago 2014, s. 206.

29 N. Przesmycka, Lublin. Przeobrażenia urbanistyczne 1815-1939, Lublin 2012, rozdz. Infrastruktura miejska s. 239-242. Zob. też J. Marczuk, Inwestycje komunalne miasta Lublina w latach 1925-1939, "Rocznik Lubelski” $1981 / 1982$, t. $23 / 24$, s. 146

3o Zob. A. Mack, Sensing Chicago..., dz. cyt.

31 W sprawie zwierząt zob.: „Zwierzęta domowe jak konie, krowy, trzoda chlewna, kozy oraz drób moga być wyłącznie trzymane w pomieszczeniach, należycie do tego dostosowanych w myśl obowiązujących przepisów, względnie wskazówek władz sanitarno-budowlanych miejskich. W każdym razie trzymanie krów, trzody chlewnej, kóz i drobiu nie może mieć miejsca w śródmieściu i w dzielnicach bardziej zabudowanych. Utrzymywanie składów szmat, kości oraz trzymanie przedmiotów w stanie rozkładu, wydzielających cuchnącą woń, w całym mieście jest wzbronione", Dziennik Zarządu m. Lublina, Lublin: Regulamin sanitarno-porządkowy, \$22 „Utrzymanie czystości wewnątrz nieruchomości”, 19.04.1932, nr 6, 1061.

32 O rozumieniu pojęcia brudu przez Mary Douglas zob. M. Douglas, Czystość i zmaza, przeł. M. Bucholc, Warszawa 2007, s. 77.

33 Zob. A.V. Wendland, "Europa" zivilisiert den "Osten": Stadthygienische Interventionen, Wohnen und Konsum in Wilna und Lemberg 1900-1930, w: A. Janatková, H. Kozińka-Witt (red.), Wohnen in der Großstadt 1900-1939, Stuttgart 2006; E. Więckowska, Opieka lekarsko-zdrowotna i sanitarna w Królewstwie Polskim na przełomie XIX i XX wieku, "Medycyna Nowożytna" 2007, nr 14/1-2, s. 55-68; A.Z. Okolski, Wykład prawa administracyjnego oraz prawa administracyjnego obowiq̨ującego w Królestwie Polskim, t. 1, Warszawa 1890, rozdz. Zarząd służbą zdrowia, s. 122-223, Policja zdrowia, s. 170-172.

34 Na przykład: Dziennik Zarządu m. Lublina, Lublin, 25.07.1934, nr 5, 1209.

35 A.V. Wendland, „Europa" zivilisiert..., dz. cyt., s. 271-296.

36 Zob. Regulamin sanitarno-porządkowy dla m. Lublina, 5.08.1931, nr 210, s. 1.

37 Np. "Głos Lubelski”, 12.11.1922, s. 4.

38 Lubelski konkurs naśladował ideę „Wielkiego Krakowa” (1910-1915) - pierwszego polskiego projektu urbanistycznego $\mathrm{w} X \mathrm{X}$ wieku mającego podnieść poziom infrastruktury, transportu zbiorowego, zdrowia publicznego i gospodarki miejskiej. Zob. P.M. Dabrowski, Cracow and Warsaw, w: E.G. Makaš, T. Damljanovic-Conley (red.), Capital Cities in the Aftermath of Empires: Planning in Central and Southeastern Europe, London-New York 2009, s. 189-207; N.D. Wood, Becoming Metropolitan: Urban Selfhood and the Making of Modern Cracow, DeKalb 2010.

39 I. Kędzierski, Jak będzie wyglądał przyszły Wielki Lublin: wyjątki z Konkursu na Szkic Regulacyjny m. Lublina, "Przegląd Lubelsko-Kresowy” 1925, nr 11, 12, http://biblioteka.teatrnn.pl/dlibra/dlibra/docmetadata?id=11057\&from=\&dirids=1\&ver_id=\&lp=1\&QI, (dostęp: 12.10.2020).

40 Zob. Z. Landau, Pożyczki ulenowskie, „Najnowsze Dzieje Polski. Materiały i Studia z Okresu 1914-1939" 1958, t. 1

41 Punktem kulminacyjnym całego konkursowego przedsięwzięcia była pożyczka (równowartość 2858000 dolarów w złotych) od American Company Ulen \& Co. Spółka ta była zakontraktowana na bu dowe urządzeń komunalnych (m.in. kanalizacji) w dziesięciu dużych polskich miastach w byłej Kongresówce w ramach zwalczania infrastrukturalnego "dziedzictwa" zaboru rosyjskiego. Zob. J. Marczuk, Budowa i rozwój urządzeń komunalnych w Lublinie w latach 1925-1939, „Kwartalnik Historii Kultury Materialnej” 1978, nr 4, s. 43.

42 P. Atkins, Animal Wastes and Nuisances..., s. 27; M.A. Kiechle, Smell Detectives: An Olfactory History of Nineteenth-Century Urban America, Seattle 2017.

43 Zob. również I. Borowy, W.D. Gruner (red.), Facing Illness in Troubled Times: Health in Europe in the Interwar Years, 1918-1939, Frankfurt am Main 2005.

44 Termin great separation wprowadził P. Atkins Zob. tenże, Introduction, w: Animal Cities..., dz. cyt., s. 1-18.

45 Tenże, Zwierzęce nieczystości..., dz. cyt., s. oryg. 50.

46 Zob. tamże: „Wielkie oddzielenie” tego, co miejskie, od tego, co wiejskie, mogło się zrodzić najpierw w umysłach, a potem w praktyce, s. oryg. 34.

47 Pierwszy zjazd higienistów odbył się w 1908 roku w Lublinie. Zob.: Dziennik zjazdu lekarzy i higienistów w Lublinie od 25 do 28 września 1908 r., "Zdrowie”, październik-listopad 1908, z. 10-11, s. 811-843; J. Cabaj, Zjazdy śródowisk medycznych Królestwa Polskiego 1908-1914, „Kwartalnik Historii Nauki i Techniki” 2006, nr 51(2), s. 99-122.

48 Cyt. za M. Denys, Lublin między wojnami: opowieść o życiu miasta 1918-1939, Lublin 2010, s. 70.

49 Zob. N.D. Wood, Becoming Metropolitan: Cracow's Popular Press and the Representation of Modern Urban Life, 1900-1915, Bloomington 2004

50 Skargi mieszkańców na nieporządki i zatruwanie powietrza można znaleźć w takich zbiorach dokumentów jak: Porzadki domowe i uliczne 17 stycznia 1928 do 4 marca 1931 (Wydział Zdrowia), APL, sygn. 352207.6.2.1.2557, jak również Porządki domowe i uliczne 12 stycznia do 22 grudnia 1931 (Wydział Zdrowia), APL, sygn. 352207.6.2.1. 
51 M. Pirogovskaya, Disgust as Civility: Perception of Sanitary Nuisances in Late Imperial Russia, w: Between Body and Mind: Emotions, Health and Medicalization, XIV Gustav Wasa Conference, Jyväskylä 2016: D.S. Barnes, The Great Stink..., dz. cyt.; J. Frykman, Pure and Rational: The Hygienic Vision: A Study of Cultural Transformation in the 1930's: The New Man, "Ethnologia Scandinavica” 1981, nr 11.

52 P. Atkins, Animal Wastes..., dz. cyt., s. 27

53 M. Douglas, Czystość i zmaza, dz. cyt

54 Porządki domowe i uliczne 1931, APL, sygn. 352207.6.2.1.2562.

55 M. Douglas, Czystość i zmaza, dz. cyt.

56 H.S. Becker, Outsiders, New York 2008.

57 Porządki domowe i uliczne 1931, APL, sygn. 352207.6.2.1.2562.

58 Porządki domowe i uliczne 1931, APL, sygn. 352207.6.2.1.2562

59 N. Przesmycka, Lublin. Przeobrażenia..., dz. cyt.

60 C.Y. Chiang, The Nose Knows: The Sense of Smell in American History, "The Journal of American History" 2008, t. 95, nr 2, s. 409. Zob. także Ch.M. Rosen, 'Knowing' Industrial Pollution: Nuisance Law and the Power of Tradition in a Time of Rapid Economic Change, 1840-1864, "Environmental History" 2003, t. 8, nr 4. 


\title{
Słoń a sprawa miejska. Ogród zoologiczny w Warszawie i konflikty wokółnowoczesnej sfery publicznej (1872-1914)
}

\begin{abstract}
Przechodzi się przez cienisty Park Praski, płaci się jeden złoty za bilet i już. Jesteśmy w Zoo. Tu za kratami lub głębokimi, wybetonowanymi rowami można zobaczyć dzikie zwierzęta, znane dotychczas tylko z egzotycznych filmów i powieści, drapieżnik Afryki, Ameryki i Azji, kawałek tego dalekiego, tajemniczego, egzotycznego świata, o którego poznaniu tak często się marzy [...] $]^{1}$.
\end{abstract}

Z punktu widzenia autorki lub autora powyższego fragmentu, zamieszczonego w latach 30. w powiązanym z Narodową Demokracją stołecznym dzienniku, powstanie w Warszawie ogrodu zoologicznego oznaczało możliwość zbliżenia się do kolonialnego spektaklu, dotychczas dostępnego jedynie za pośrednictwem wizualnych i narracyjnych reprezentacji. Uzyskanie w przestrzeni miasta stałego dostępu do egzotycznej fauny miało być dla jego mieszkańców szansą na przekroczenie swojej uporczywie peryferyjnej pozycji. Wyobrażenia o stołecznym zwierzyńcu jako skutecznej ekspresji narodowych aspiracji modernizacyjnych miały już wówczas swoje długie trwanie. Gdy w roku 1928 utworzono ogród na warszawskiej Pradze, kontekstem dla jego zaistnienia była gęsta sieć narracji powstałych w drugiej połowie XIX i na początku XX wieku.

Narracje te kształtowały się w wyniku długotrwałych i nieciągłych procesów dyskursywnych i materialnych, obejmujących trzy próby realizacji projektu ogrodu zoologicznego w Warszawie w latach 1872-1875, 1884-1890 i 1908-1914. Owych procesów, które doprowadziły do powstania warszawskiego zwierzyńca, nie da się opisać jedynie za pomocą narracji stworzonych przez zachodnie historyczki kulturowe, kładące w badaniach dziewiętnasto- i dwudziestowiecznych ogrodów zoologicznych nacisk na kontekst kolonialnej ekspansji oraz służące jej legitymizacji reżimy wiedzy. O ile analizy te dostarczają wyczerpujących interpretacji modelowych instytucji zoologicznych w krajach kapitalistycznego centrum, o tyle w przypadku badania ich peryferyjnych odpowiedników konieczne jest wyeksponowanie także lokalnych trajektorii modernizacyjnych i powiązanych z nimi dyskursów politycznych.

W swojej Historii ogrodów zoologicznych na Zachodzie, ważnej pracy z zakresu „ludzkiej” historii zwierząt, Elisabeth Hardouin-Fugier i Éric Baratay wyróżniają trzy fale rozprzestrzeniania się idei nowoczesnego ogrodu zoologicznego w Europie. Pierwsza - będąca bezpośrednim efektem oddziaływania utworzonego w czasie rewolucji francuskiej zwierzyńca publicznego w paryskim Jardin des Plantes - obejmuje Wielką Brytanię, gdzie proces ten rozpoczął się w latach 20. XIX wieku. Druga dotyczy Holandii i Belgii, gdzie ogrody zaczęły powstawać w latach 
30. i 40. Trzecia odnosi się do Prus, a następnie Cesarstwa Niemieckiego, gdzie od lat 60. trwał boom na ogrody zoologiczne. Hardouin i Baratay nie włączają do swojego modelu Europy Wschodniej, Północnej oraz Południowej, wyliczając jedynie niektóre miasta, w których ogrody powstały wraz z datami ich utworzenia, w tym: Kopenhagę (1859), Moskwę (1863), Budapeszt (1865), Barcelonę (1892) i Rzym (1910). Dla Warszawy podają rok 1911 - datę nie tylko błędną2, lecz także nieuwzględniającą wcześniejszych prób utworzenia ogrodu zoologicznego w stolicy Królestwa Polskiego. Pomyłka francuskich autorów jest z pewnością symptomatyczna - świadczy zarówno o skłonności do marginalizacji regionów peryferyjnych w historycznych syntezach, jak i o sztuczności modeli, które w odniesieniu do dziewiętnastowiecznej epoki wczesnej globalizacji zakładają odrębność Europy Zachodniej. Prześledzenie historycznego kontekstu, w którym rozwijała się koncepcja ogrodu zoologicznego w Warszawie, dowodzi, że procesy opisywane przez Barataya i Hardouin przebiegały równolegle poza centrum, a kształt nadawały im zarówno dominujące europejskie wzorce, jak i lokalne stosunki3 ${ }^{3}$.

Poniższy tekst stanowi próbę wpisania historii warszawskiego ogrodu zoologicznego w szerszą opowieść o kształtowaniu się na ziemiach polskich wyobrażeń na temat nowoczesności. Punktem wyjścia moich analiz jest aspiracyjny paradygmat modernizacji, po stronie którego opowiadali się piszący na temat ogrodu zoologicznego autorzy z kręgu pozytywistycznej inteligencji. Przyglądam się temu, w jaki sposób kreślona przez nich wizja utworzenia w stolicy Królestwa Polskiego ogrodu zoologicznego skupiała w sobie elementy składające się na pozytywistyczne rozumienie nowoczesności. W dalszych częściach tekstu analizuję również przeciwnarracje tnące w poprzek dominującej osi dyskursywnej. Zaczęły się one rozwijać intensywnie na początku XX wieku w wyniku, po pierwsze, uwidaczniania się antagonizmu klasowego, który od samego początku określał dynamikę dyskusji wokół ogrodu zoologicznego, a po drugie, rozwoju ruchu kobiecego, którego przedstawicielki agitowały na rzecz moralności publicznej i protestowały przeciwko okrucieństwu wobec zwierząt. Moim celem jest przywrócenie pamięci o społecznych konfliktach, w które uwikłani byli nie-ludzcy mieszkańcy Warszawy na przełomie XIX i XX wieku.

\section{Ogród zoologiczny w pozytywistycznych projektach samomodernizacji}

Kiedy w latach 60. i 70. XIX wieku w prasie Królestwa Polskiego po raz pierwszy toczyła się dyskusja o utworzeniu w Warszawie ogrodu zoologicznego, spory na łamach stołecznych dzienników i czasopism zaczynali dominować publicyści z kręgu pozytywistów warszawskich. Przedstawiciele tego środowiska, reprezentujący rodzącą się w warunkach postyczniowych młodą, aspirującą klasę umysłową, widzieli w instytucjach tworzonych na wzór sfery publicznej zachodnich metropolii drogę do postępu cywilizacyjnego w warunkach imperialnej zależności ${ }^{4}$. Zgodnie z wyznawaną przez nich koncepcją rozwoju, to w szczególności przestrzenie odpowiedzialne za dystrybucję wiedzy: galerie sztuki, muzea czy placówki naukowe miały stanowić instytucjonalne ramy stopniowej, oddolnej samomodernizacji polskiego społeczeństwa. W Warszawie istniał już wówczas Gabinet Zoologiczny, powołany w 1818 roku przy Królewskim Uniwersytecie Warszawskim, którego zbiory taksydermiczne udostępniano w wybrane dni publiczności. Choć pojawiały się głosy mówiące, że trzeba zadbać przede wszystkim o zwiększenie frekwencji w salach gabinetu ${ }^{5}$, coraz liczniejsi autorzy opowiadali się za stworzeniem w Warszawie „ogrodu aklimatyzacyjnego dla zwierząt” (jak nazywano w tym okresie ogrody zoologiczne), który służyłby upowszechnianiu wiedzy na temat systematyki gatunków i dostarczał przestrzeni spacerowej dla mieszkańców miasta.

Z formułą nowoczesnego ogrodu zoologicznego przedstawiciele lokalnych elit mogli wówczas zapoznać się podczas podróży do większości dużych miast Europy Zachodniej, a od niedawna także Moskwy i Sankt Petersburga. Prasa Królestwa regularnie drukowała artykuły przybliżające czytelnikom sposoby urządzenia zagranicznych zwierzyńców, ze szczególną uwagą śledząc ich gwałtowny rozwój na terytorium niemieckim. Celem tego gatunku publicystyki było skojarzenie ogrodów w zbiorowej wyobraźni z dynamiką społeczeństw i ośrodków, które uchodziły za skuteczne w stawianiu czoła wymogom nowoczesności. 
Perspektywa zaadaptowania wzorca instytucji zoologicznej stworzonego w zachodnich metropoliach do lokalnych warunków wiązała się z koniecznością międzynarodowego transferu nie tylko wiedzy, lecz także modelu działalności publicznej. Ogrody zoologiczne od Londynu po Antwerpię były przeważnie zakładane przez prywatne towarzystwa naukowe, legitymujące się autorytetem znanych przyrodników i dysponujące łatwym dostępem do kolonialnego handlu zwierzętami. Problemem, z którym musieli się zmierzyć pierwsi entuzjaści ogrodu zoologicznego w Warszawie, było powołanie organizacji zdolnej do zarządzania zwierzyńcem w warunkach peryferyjnego ograniczenia zasobów i podległości politycznej. Już w 1860 roku, gdy „Magazyn Mód i Nowości Dotyczących Gospodarstwa Domowego" wydrukował szczegółową relację z ceremonii otwarcia przez Napoleona III nowego ogrodu zoologicznego w paryskim Bois de Boulogne, korespondent czasopisma przekonywał o potrzebie stworzenia zwierzyńca w Warszawie. Opisując huczne wydarzenie jako sukces Société zoologique d'acclimatation (kierowanego przez francuskiego zoologa Isidore'a Saint-Hilaire), autor relacji wskazywał na założone kilka lat wcześniej Towarzystwo Rolnicze jako organizację, która powinna zająć się sprowadzeniem do Warszawy egzotycznych gatunków zwierząt: „tyle prób aklimatyzacyjnych udało się ludziom do

W wyobraźni dziewiętnastowiecznych publicystów ogród zoologiczny miał więc odtwarzać w przestrzeni miasta podział klasowy, w ramach którego przedstawicielom klas podporządkowanych przypadała rola biernych odbiorców kultury dominującej.

ograniczonych, bo indywidualnych sprowadzonych środków; dlaczegóżby stowarzyszeniom, którym wiek XIX tyle już zadziwiających winien dzieł i wynalazków, nie udało się nawet mozolnych i upartych pokonać trudności?”.

Za pierwszą próbę fizycznej realizacji projektu miejskiego ogrodu zoologicznego w Warszawie uchodzi niewielka menażeria na tyłach ulicy Hożej, założona w 1872 roku przez emerytowanego guwernera Instytutu Szlacheckiego Ferdynanda Bartelsa. Zwierzyniec, który formalnie należał do spółki komandytowej Bartels, Kloss et Comp., miał funkcjonować w ramach struktury własnościowej opartej na finansowym wkładzie akcjonariuszy, charakterystycznej dla pozytywistycznego modelu działalności gospodarczej ${ }^{7}$. Choć Bartels przewidywał dla swojego zakładu raczej funkcję placówki hodowlanej, jedynie wtórnie realizującej cele popularyzatorskie i rozrywkowe, nie można go pominąć przy pisaniu o wykształcaniu się na ziemiach polskich wyobrażeń na temat nowoczesnego ogrodu zoologicznego - przede wszystkim dlatego, że właśnie w tych kategoriach postrzegali go współcześni widzowie i publicyści ${ }^{8}$. Co więcej, Bartels współtworzył obywatelski Komitet Opiekuńczy do Urządzenia Zwierzyńca w Warszawie - pierwsze zbiorowe ciało agitujące na rzecz utworzenia publicznego zwierzyńca w stolicy, które nie odniosło jednak trwałych sukcesów.

Proces wpisywania praktyk ekspozycji zwierząt w typową dla dyskursu pozytywistycznego retorykę scjentyzmu i ekonomizacji można było zaobserwować już na przykładzie wydanej przez Bartelsa broszury O potrzebie spożytkowania istniejącego już u nas zamiłowania do zwierząt w celu podniesienia dobrobytu ogółu, w której przedstawił on argumenty za powołaniem zwierzyńca w Warszawie. Bartels zapowiedział, że zamierza stworzyć modelowy zakład hodowlano-wystawienniczy, który będzie zajmował się aklimatyzacją pożytecznych gatunków do polskiego klimatu, a z czasem przybierze formę ogrodu zoologicznego. W swoim tekście kładł nacisk na potrzebę wykorzystania „narodowo-ekonomicznego znaczenia” instytucji ogrodu, z którym zapoznał się, będąc „w ścisłych stosunkach z wielu znakomitymi mężami, pracującymi w tej gałęzi

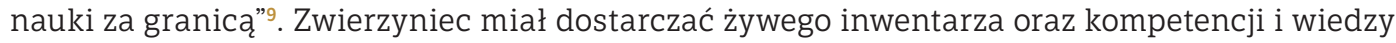


w zakresie nowoczesnych metod hodowli, wspomagając w ten sposób rozwój indywidualnej aktywności gospodarczej. Powołując się na „cyfry statystyczne” dotyczące chowu różnych gatunków zwierząt we Francji, Anglii i Niemczech, Bartels wyrażał nadzieję, że „zamiłowanie to zakwitnie i u nas, rozpowszechni i stanie się obfitym źródłem bogactwa narodowego"10. Po dokonaniu szczegółowych wyliczeń spekulował, że tylko dzięki rozpowszechnieniu hodowli kóz, królików, gołębi i kur gospodarka Królestwa Polskiego mogłaby wzbogacić się o ponad milion rubli rocznie.

Po kilku latach pozbawionej sukcesów działalności zwierzyniec Bartelsa został zamknięty, a żyjące w nim zwierzęta zlikwidowane przez miejskiego rakarza. Jednak przekonanie o modernizacyjnym potencjale instytucji ogrodu zoologicznego na stałe weszło już do zbiorowej wyobraźni. Dekadę później, w 1884 roku w położonej przy Rogatkach Mokotowskich Bagateli otworzył się większy, bardziej reprezentacyjny prywatny zwierzyniec. Ogród w Bagateli miał przejść na własność miasta po dziesięciu latach, jednak został zamknięty w 1890 roku w wyniku niedoborów budżetowych oraz wypadku, który spowodował śmierć większości drapieżników. W okresie swojej działalności cieszył się jednak popularnością wśród mieszkańców miasta, oferując zróżnicowaną kolekcję miejscowych oraz egzotycznych zwierząt.

Założycielem spółki zarządzającej ogrodem był prawnik i publicysta związany ze środowiskiem pozytywistów, Jan Maurycy Kamiński. Sylwetka Kamińskiego, absolwenta Szkoły Głównej w ostatnim roku jej funkcjonowania, jest emblematyczna dla pokolenia wyrosłej na gruncie postyczniowym inteligencji1․․ Na podstawie broszury z 1885 roku można zrekonstruować język, za pomocą którego wpisywał on zwierzyniec w narrację o zbiorowym wysiłku modernizacyjnym. Powołując się na oficjalne dane statystyczne ze sporządzonego trzy lata wcześniej pierwszego spisu ludności Warszawy ${ }^{12}$, Kamiński przekonywał, że ogród zoologiczny stanowi rodzaj cywilizacyjnego sprawdzianu, który zaświadczać ma o gorliwości wykształconych mieszkańców miasta w dążeniu do statusu nowoczesnych Europejczyków: „Profesor Załęski narachował w Warszawie przeszło 180000 osób umiejących czytać. Przekonajcie, że się nie pomylił. [...] Społeczeństwa cywilizowane zrozumiały od dawna pedagogiczne i obyczajowe znaczenie zwierzyńców i mamy je na Zachodzie w każdym większym mieście. Niewątpliwie i u nas wiele osób podziela te same zapatrywania"13.

\section{Naukowe aspiracje i kompleks masowej rozrywki}

Przemiany struktury społecznej Królestwa Polskiego w drugiej połowie XIX wieku, wywołane jego postępującą subsumcją pod globalną gospodarkę oraz procesami kapitalistycznej urbanizacji, sprzyjały wzrostowi znaczenia miejskiej klasy średniej oraz burżuazyjnej sfery publicznej. Dyskurs wytwarzany przez publicystów z kręgu pozytywistycznej inteligencji, którzy przekonywali o potrzebie stworzenia w Warszawie ogrodu zoologicznego, był elementem tego procesu. Odwołując się do abstrakcyjnych wyobrażeń na temat „postępu” i „kultury”, zdradzali oni swoją wąską klasową perspektywę oraz fałszywy uniwersalizm, rozciągający interesy i wyobrażenia klasy średniej na społeczeństwo jako całość.

Język klasowej dystynkcji najmocniej wybrzmiewał w próbach uprawomocnienia ogrodu zoologicznego jako instytucji naukowej. Ponieważ dla zróżnicowanych klasowo mieszkańców miasta nowoczesny zwierzyniec niekoniecznie musiał radykalnie odróżniać się od wcześniejszych form ekspozycji zwierzą ${ }^{14}$, konieczne było podkreślanie ich odrębności. Antytezą dla wyobrażenia o ogrodzie zoologicznym jako medium postępu stały się prywatne kolekcje arystokratyczne oraz obwoźne menażerie będące elementem ludowej rozrywki masowej. Ferdynand Bartels przekonywał, że dawniej zwierzyńce zakładano jedynie „dla urządzenia krwawych igrzysk, już też dla okazania przepychu dworów swoich” i dopiero współcześnie stały się one „potrzebą wyższej oświaty i dzisiaj mają znaczenie edukacyjnych zakładów społecznych, które [...] rozszerzają zamiłowanie do nauk przyrodzonych, wpływających na pojęcia religijne i na podniesienie moralności"15.

Gdy w roku 1884 w powstanie ogrodu w Bagateli zaangażowali się profesor Jerzy Aleksandrowicz (były dyrektor Ogrodu Botanicznego i założyciel Ogrodu Pomologicznego na Muranowie) oraz Władysław Taczanowski (kustosz Gabinetu Zoologicznego), publicyści 
z zadowoleniem pisali, że „zainteresowanie [...] projektem zwierzyńca wywołane w gronie przyrodników tutejszych daje pewność, że ogród zoologiczny znajdzie poparcie w tych sferach, które mu pozwoli oprzeć się w szczegółach organizacji na naukowych podstawach"16. O naukowym charakterze zakładu miały zaświadczać również specjalnie organizowane odczyty o tematyce biologicznej, które wygłaszał August Wrześniowski, profesor Cesarskiego Uniwersytetu Warszawskiego, a także współpraca z Józefem Nusbaumem-Hilarowiczem, autorem polskiego przekładu O powstawaniu gatunków Darwina, który na początku swojej kariery prowadził badania w ogrodzie Kamińskiego ${ }^{17}$.

Próby zademonstrowania naukowego charakteru ogrodu zoologicznego wpisywały się w szerszy projekt, jakim było dążenie rozwijającej się polskiej klasy średniej do ustanowienia hegemonii własnego modelu kultury, w tym publicznych form rozrywki i praktyk związanych z celebrowaniem czasu wolnego. O tym, że zwolennicy instytucji zwierzyńca postrzegali ją jako przeznaczoną dla reprezentantów warstw uprzywilejowanych, jednoznacznie świadczy tekst Jana Maurycego Kamińskiego z 1885 roku, w którym wykluczył on spośród domyślnych adresatów swojej odezwy pracowników najemnych, pisząc: „Kto nie ma czasu lub ochoty iść sam, niech kupi bilet swemu podwładnemu, terminatorowi, służącym"18.

Wyższościowy stosunek do warstwy ludowej oraz kultywowanych przez nią rozrywek stanowił istotny element społecznego imaginarium zaangażowanej w pozytywistyczny projekt modernizacyjny inteligencji. W okresie, gdy w Warszawie pojawiły się pierwsze projekty założenia publicznego ogrodu zoologicznego, jarmarczne menażerie w dalszym ciągu były obecne w przestrzeni miasta - w tym najbardziej znana, należąca do Gottlieba Christiana Kreutzberga, niemieckiego potentata, który regularnie organizował tournée w głąb Imperium Rosyjskiego. Pokazy żywych zwierząt stanowiły element tak zwanych zabaw ludowych, odbywających się najczęściej na placu Ujazdowskim, gdzie wystawiano je obok panoram, gabinetów anatomicznych, kolekcji figur woskowych i wyświetlanych z przezroczy „niknących obrazów”. Przekonując o negatywnym wpływie popularnych zabaw na moralność publiczną i estetykę miasta, liczni publicyści domagali się całkowitego usunięcia z przestrzeni miejskiej menażerii „z wiecznie śpiącym jaguarem i krową o pięciu nogach”19 oraz utworzenia w ich miejsce „czegoś w rodzaju zabaw ludowych dla klas średniozamożnych”. Krytyczny stosunek do jarmarcznych form rozrywki podzielały także władze miejskie. Gdy w 1912 roku magistrat wydał zgodę na przekazanie gruntów w parku Praskim pod budowę zwierzyńca, w uchwale pojawił się zapis, że dzierżawa obowiązywać będzie „dopóty tylko, dopóki ogród będzie służył celom kulturalnym”2o. Jako negatywny przykład urzędnicy przywoływali ogród zoologiczny w Petersburgu, który - jak uważali - zamiast rozpowszechniać wiedzę naukową i dostarczać mieszkańcom miasta eleganckiej rozrywki „jest przybytkiem kabaretów i innych tego rodzaju instytucji”.

W wyobraźni dziewiętnastowiecznych publicystów ogród zoologiczny miał więc odtwarzać w przestrzeni miasta podział klasowy, w ramach którego przedstawicielom klas podporządkowanych przypadała rola biernych odbiorców kultury dominującej. Wyobrażenie o miejskim zwierzyńcu jako narzędziu klasowej asymilacji było od XIX wieku stałym elementem dyskursów na temat społecznej funkcji ogrodów zoologicznych. Zoological Society of London, zarządzające londyńskim ogrodem w Regent’s Park, początkowo miało bardzo ekskluzywny charakter, dopuszczając do członkostwa jedynie przedstawicieli klas wyższych związanych finansowo lub intelektualnie z działalnością naukową. Jednak istniejące restrykcje nie ograniczyły dostępu do zwierzyńca niżej usytuowanym mieszkańcom metropolii. Stopniowe wkraczanie mas w przestrzeń Regent's Park spotkało się z niejednoznaczną reakcją elit - choć początkowo ową niechcianą obecność postrzegano jako próbę „zanieczyszczenia” szeregów towarzystwa, wkrótce wpleciono ją w dyskurs umoralniania i edukowania klas podporządkowanych ${ }^{21}$. Podobny ton można odnaleźć w felietonach Bolesława Prusa z lat 70. XIX wieku, w których przedstawiał on ogród zoologiczny jako szansę na to, aby oświecić „dobry, ale ciemny proletariat”22 Warszawy.

Mechanizm wpisywania ogrodu zoologicznego w struktury społecznej dominacji, które wyznaczały proletariackim masom podporządkowaną pozycję, obejmował także inne pozbawione władzy grupy. W okresie działalności ogrodu w Bagateli ujawniły się dążenia pozytywistycznej inteligencji do europejskiego modelu nowoczesności ze wszystkimi jego elementami składowymi, włącznie z fantazją o dominacji nad urasowionymi populacjami kolonialnymi. Do Warszawy 
kilkakrotnie sprowadzono wówczas Völkerschau na niemieckich licencjach, między innymi grupy syngaleskich performerów z Cypru, biorących udział w zorganizowanym przez przedsiębiorstwo Hagenbecka tournée po Europie ${ }^{23}$.

Peryferyjne pragnienie uczestniczenia w kolonialnym projekcie ekspansji, opartym na ideologii rasowej supremacji, było jednak wpisane także w codzienne funkcjonowanie ogrodu. W numerze „Biesiady Literackiej” opublikowanym w 1884 roku, kilka miesięcy po otwarciu zwierzyńca zamieszczono dwie ilustracje sporządzone w Bagateli. Pierwsza przedstawia ogród jako typową dziewiętnastowieczną przestrzeń odpoczynku i rozrywki, w której miejska klasa średnia spędza wolny czas na spacerach, rozmowach oraz zabawach z dziećmi. Druga wpisuje tę samą przestrzeń w konwencję wizualnej klasyfikacji typową dla nowoczesnej systematyki gatunków. Wśród uszeregowanych obok siebie i opatrzonych informacyjnymi podpisami reprezentacji zwierząt przedstawiony został także czarnoskóry mężczyzna w liberii i fezie, który - jak wynika z towarzyszącego ilustracjom artykułu - został zatrudniony przez zarząd ogrodu w charakterze odźwiernego. Autor tekstu podaje, że mężczyzna ten władał kilkoma językami słowiańskimi (choć nie polskim) i swobodnie komunikował się z publicznością goszczącą w ogrodzie, lecz zarazem był przez nią oglądany niczym „także coś z ogrodu zoologicznego [podkr. oryg.]"24.

\section{Kontrnarracje}

Likwidacja ogrodu w Bagateli w 1890 roku obnażyła słabości zapoczątkowanego przez pozytywistów dyskursu aspiracyjnego. W konsekwencji w ostatniej dekadzie XIX wieku nastąpiła zmiana w stosunku części warszawskiej opinii publicznej do instytucji ogrodu. Co prawda „Kurier Poranny” podawał, że po likwidacji zwierzyńca w Bagateli, w nadziei na ponowne otwarcie instytucji „reklamiarze ogłaszają odstąpienie rabatu od sprzedanych towarów na rzecz zwierzyńca, biedni kolejarze robią między sobą składki, p. Lewandowski zapowiada koncert orkiestrowy”25 i „szał jakiś ogarnia Warszawę”, to jednak przedstawiciele prasy coraz częściej stwierdzali, że ogród zoologiczny jest „ozdobą raczej, zbytkiem wielkich miast, niż ich potrzebą", na który Warszawa na obecnym etapie rozwoju organizmu społecznego nie może sobie pozwolić ${ }^{26}$

Mimo tych zmian, Zygmunt Kramsztyk, lekarz żydowskiego pochodzenia i jedna z czołowych postaci Towarzystwa Miłośników Przyrody, zdecydował się powołać w 1908 roku Towarzystwo Akcyjne „Ogród Zoologiczny w Warszawie”, które zbierało środki na rzecz ponownego otwarcia w Warszawie miejskiego zwierzyńca. Przychylni inicjatywie dziennikarze upominali opinię publiczną, że placówki zoologiczne powstały już w bardziej prowincjonalnych ośrodkach regionu - Rydze, Wrocławiu i Poznaniu ${ }^{27}$ - co zagraża statusowi Warszawy jako liczącego się ośrodka kulturalno-gospodarczego. „[N]ajwiększe miasto polskie pod względem zaludnienia [...] nie posiada dotychczas ogrodu zoologicznego, tej naukowej i kulturalnej instytucji, z jakiej od dawna korzysta kilkadziesiąt mniejszych miast Europy - pisano. - Wobec tego byłoby wstydem pozostać w tyle, przyznając się niejako do niższej kultury"28.

Działania Kramsztyka i jego współpracowników, które przypadły na lata 1908-1914, wyznaczają trzeci okres, kiedy na łamach warszawskiej prasy z ożywieniem dyskutowano o pomyśle stworzenia ogrodu zoologicznego w Warszawie. Ich najbardziej wymiernym sukcesem było uzyskanie zgody władz miejskich na ulokowanie przyszłego ogrodu w parku Praskim, choć wybuch I wojny światowej uniemożliwił dalszą realizację projektu.

Na początku XX wieku siatka dyskursywna, w której musieli odnaleźć się Kramsztyk i członkowie jego Towarzystwa, była jednak zdecydowanie bardziej skomplikowana niż pod koniec poprzedniego stulecia. Od projektu ogrodu zoologicznego odwróciło się Towarzystwo Opieki nad Zwierzętami, które jeszcze w latach 80. XIX wieku deklarowało, że „działalność ogrodu wchodzi na grunt dążności propagowanych zasadniczo przez Towarzystwo"29. Wraz z wkraczaniem marginalizowanych dotąd grup społecznych w obszar nowoczesnej sfery publicznej ${ }^{30}$, również w dyskusjach na temat ogrodu zoologicznego pojawiły się nowe głosy.

Gdy w roku 1912 Towarzystwo uzyskało od władz miasta pozwolenie na dzierżawę terenu w parku Praskim, redakcja „Steru” (czasopisma wydawanego przez Związek Równouprawnienia 
OGROD ZOOLOGICZNY W WARSZA WIE.

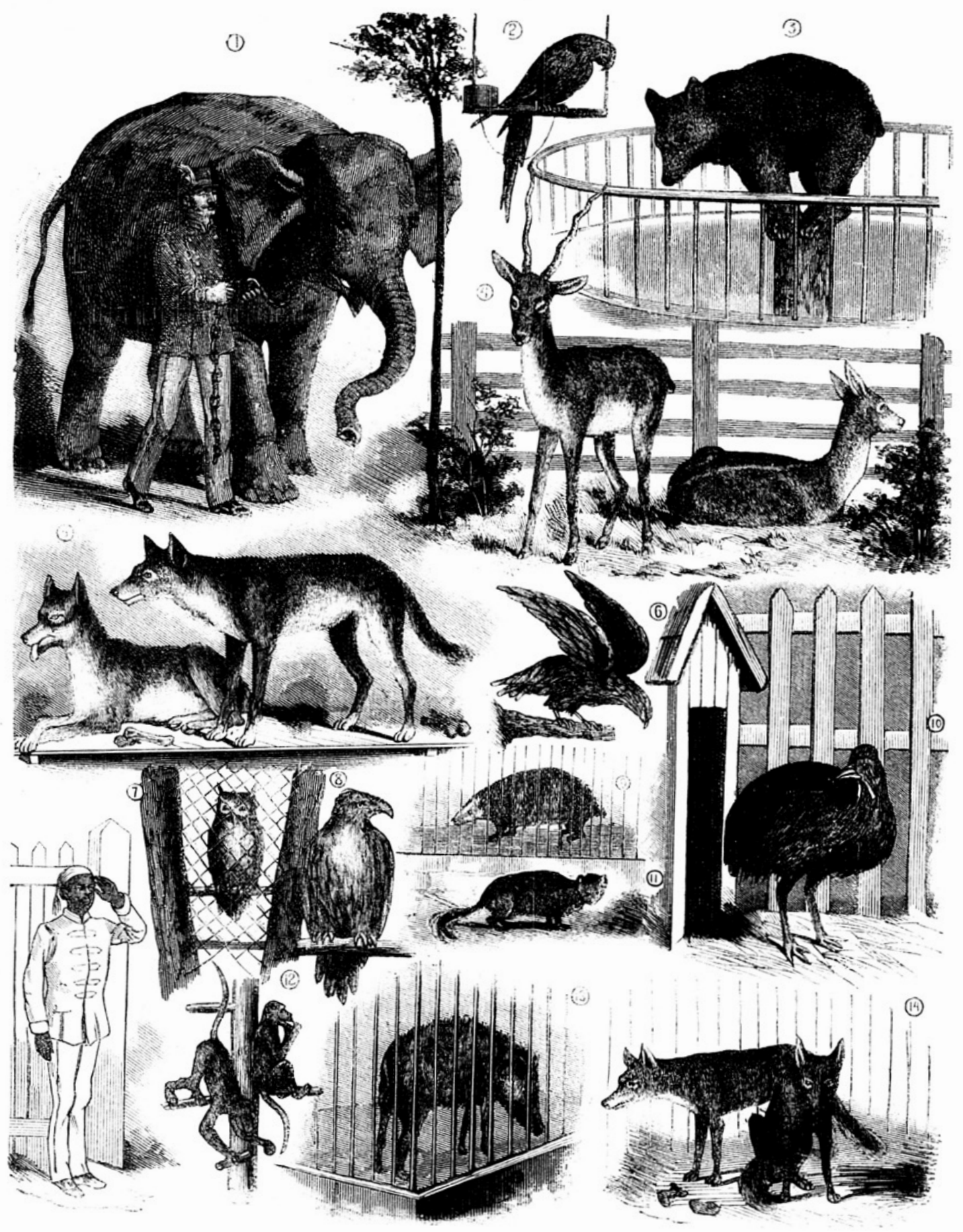

1 Sloń. 2 Ara. 3 Niedźwiedz. 4 Antylopy. 5 Wilki. 6 Jastrzą), 7 l'ubacz.

8 Orzeł z Karpat. 9 Borsuk. 10 Kazuar. 11 Kuna. 12 Malpy. 13 Dzik. 14 Lisy.

Rysowal Zajilel. 
$0 G R O D Z O O L O G I C Z N Y W$ WARSZAWIE.

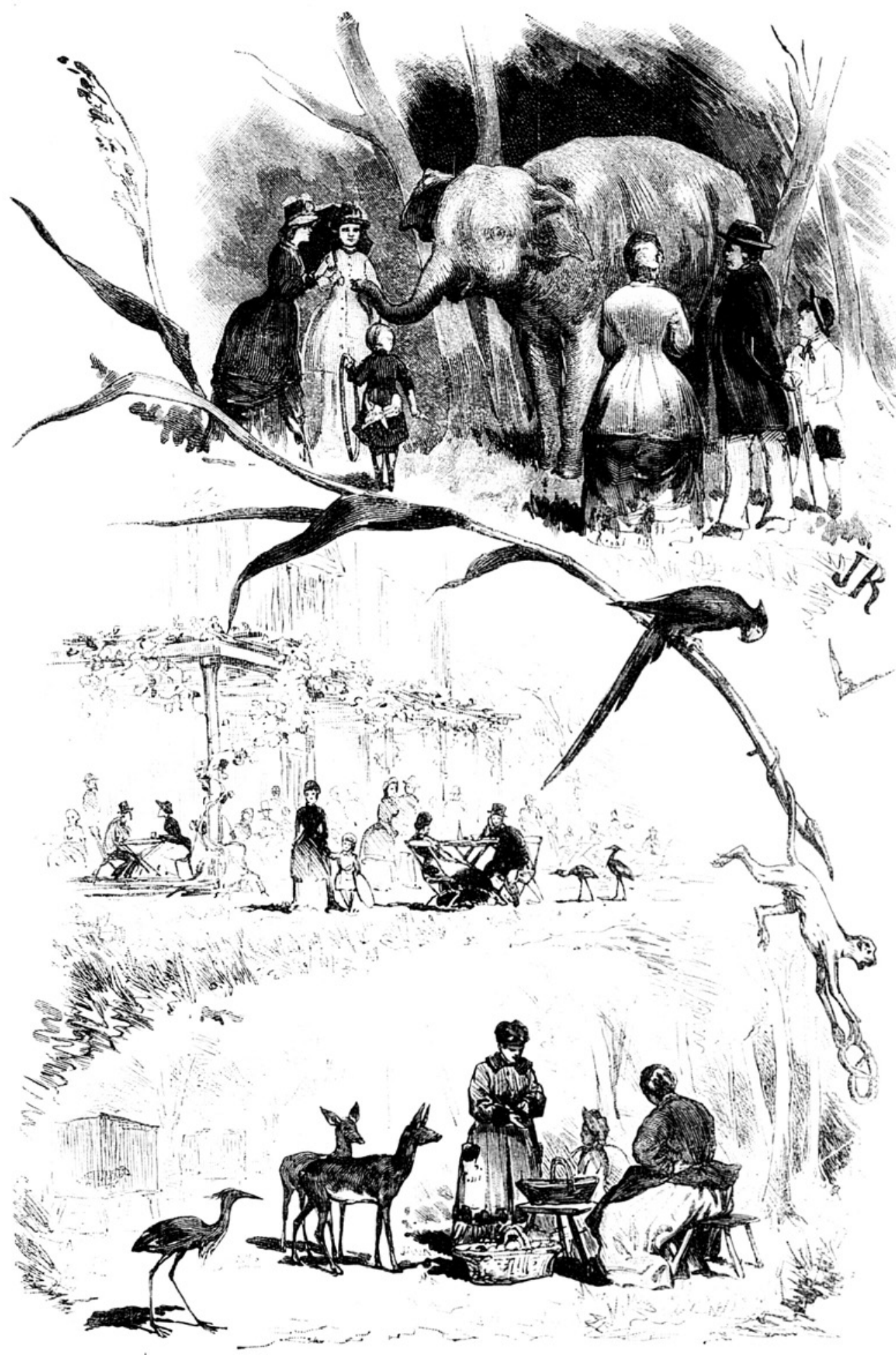

Pieszczoty ze sloniem. - Pod werendą paiacyku. - Przy wrotach zwierzynica.

Rysonal J. Rysziewic: 
Kobiet Polskich) zamieściła felieton Zofii Okęckiej podający w wątpliwość etyczną i naukową wartość instytucji zwierzyńca. Autorka tekstu starała się przekonać czytelniczki, że czerpanie przyjemności z widoku przetrzymywanych w niewoli zwierząt stoi w sprzeczności ze społecznymi zadaniami ruchu kobiecego, który powinien raczej łagodzić obyczaje za pomocą macierzyńskiej etyki troski. Kładąc nacisk na kondycję moralną młodego pokolenia, raczej niż na rzeczywisty dobrostan zwierząt („Usuwajmy widok krzywdy sprzed oczu naszych dzieci!”31), autorka krytykowała przemocowy i komercyjny charakter instytucji ogrodu, skrywany pod cienką warstwą dydaktyzmu:

Ogród zoologiczny - to więzienie dla zwierząt, którym wolność i swoboda, jak wszystkim tworom przyrody, do życia jest potrzebna. Tymczasem ludzie z kulturą zajmują się z całym oddaniem, nie szczędząc trudów, sprowadzeniem zza oceanu wolnych dzieci natury, aby uwięzić je w klatkach, na łańcuchach i wtedy zaprosić do ogrodu zoologicznego publiczność [...] Szczególnie my, kobiety, nie powinniśmy pozwalać na krzywdę niczyją, bo naszym zadaniem jest, by krzywda wszelka zniknęła z oblicza ziemi [... ${ }^{32}$.

Zaangażowanie przedstawicielek ruchu kobiecego w protesty przeciwko brutalności wobec zwierząt stanowiło w ówczesnej Europie powszechne zjawisko. Odwołując się do kontekstu Wielkiej Brytanii, Coral Lansbury analizowała udział aktywistek kobiecych w protestach przeciwko wiwisekcji na przełomie XIX i XX wieku. Lansbury wysunęła tezę, że obrazy przemocy doświadczanej przez zwierzęta ze strony medycznego aparatu naukowego stały się dla nich poręczną metaforą własnej opresji ${ }^{33}$. Felieton w „Sterze” nie był pierwszym głosem sprzeciwu wobec ogrodu zoologicznego, który angażował wyobrażenia na temat płci w dyskusję wokół niewoli zwierząt. Kilka lat wcześniej na łamach „Nowej Gazety” anonimowa „Prenumeratorka” opublikowała głęboko krytyczny wobec projektu miejskiego zwierzyńca list. Na tych samych łamach odpowiedział jej Zygmunt Kramsztyk:

Czuła osoba w jedwabiach, z piórami ptasimi lub całym ptakiem na kapeluszu, w ozdobnym obramowaniu futrzanym - dla ozdoby nie dla ciepła - gorącymi słowy występuje w obronie zwierząt, dręczonych w zwierzyńcu. [...] Żadne zwierzę w zwierzyńcu nie żyje w warunkach tak okropnych, jak panna w kiosku [...] A stokroć gorzej jeszcze przepędzają całe życie liczne tysiące w podziemiach Starego Miasta albo Krochmalnej ${ }^{34}$.

W reakcji na zarzuty stawiane przez „Prenumeratorkę” Kramsztyk przyjął strategię mającą na celu przeciwstawienie obrazu uprzywilejowanej kobiety z klasy wyższej, epatującej fałszywą troską o dobrostan zwierząt, uciskanym proletariackim masom. Jednak źródła z tego samego okresu nie wskazują, aby środowiska ludowe lub robotnicze darzyły projekt ogrodu zoologicznego entuzjazmem. Różnica klasowa, która w dyskursie pozytywistycznym odnosiła się do wyobrażeń na temat wychowawczych funkcji zwierzyńca, stała się teraz źródłem krytyki projektu ogrodu zoologicznego. Wraz z narodzinami masowej polityki oraz rozwojem zorganizowanego ruchu socjalistycznego i ludowego w sferze publicznej pojawiły się głosy konkurencyjne, upatrujące w projekcie ogrodu zbytek, który powinny poprzedzić pilne reformy socjalne ${ }^{35}$. W 1912 roku w jednym z numerów tygodnika „Zaranie” (którego działacze współtworzyli później PSL „Wyzwolenie") ukazał się artykuł o wymownym tytule Ogród zoologiczny zamiast pomocy ludziom:

Przyszło komuś do głowy, że w Warszawie trzeba założyć ogród zoologiczny. [...] Są [...] w całym kraju tak wielkie potrzeby uzdrowienia społecznego ludzi, że myśleć, żeby w tej biedzie, a strasznej niekiedy nędzy ludzkiej zakładać bardzo kosztowny zwierzyniec, trzeba chyba... być wielkomiejskim dzieciuchem ${ }^{36}$.

Zestawienie powyższych fragmentów, wyrażających różne stanowiska wobec instytucji ogrodu zoologicznego, ujawnia stopniowe rozchodzenie się na przełomie XIX i XX wieku 
dyskursów na temat modernizacji. Opartej na społecznym i politycznym znaczeniu klasy średniej pozytywistycznej wizji ogrodu zoologicznego jako instytucji burżuazyjnej sfery publicznej przeciwstawił się na początku XX wieku z jednej strony ruch kobiecy, a z drugiej ruchy ludowe i robotnicze. Ten pierwszy kwestionował naukowy oraz edukacyjny wymiar zwierzyńców, wskazując na etyczny i pedagogiczny aspekt eksponowania zwierząt w zamkniętej przestrzeni. Ten drugi zaś podkreślał wtórność burżuazyjnej wizji edukacji klas ludowych i robotniczych wobec materialnych oraz społecznych potrzeb owych grup społecznych.

\section{PRZYPISY}

1 Egzotyka za kratami w ogrodzie zoologicznym, "Warszawski Dziennik Narodowy” 1938, nr 178B, s. 8.

2 Wskazując na rok 1911, Hardouin i Baratay odnosza sie prawdopodobnie do daty przekazania przez warszawski magistrat terenów w parku Praskim Towarzystwu Akcyjnemu "Ogród Zoologiczny", które działało od 1908 roku pod kierownictwem Zygmunta Kramsztyka. Jednak również przy takiej interpretacji jest to data nieścisła, ponieważ wydział administracyjny wydał zgodę na udzielenie Towarzystwu dzierżawy gruntów dopiero w roku 1912.

3 Por. O. Hochadel, Going East. Gustave Loisel and the Networks of Exchange Between Zoological Gardens Before 1914, w: Interurban Knowledge Exchange in Southern and Eastern Europe, 1870-1950, w: E. Gantner, H. Hein-Kircher, O. Hochadel (red.), Routledge, New York 2020.

4 Por. J. Kubicka, Na przełomie. Pozytywiści warszawscy i pomoc własna, Warszawa 2016, s. 217-270.

5 „Bardzo wiele mówiono i pisano o ogrodzie zoologicznym w Warszawie; są to dla nas gruszki na wierzbie; ale nikt nie zwraca uwagi w jaki sposób gabinet zoologiczny na użytek publiczny bywa dozwalany", Gabinet zoologiczny, "Gazeta Polska” 1876, nr 21, s. 2.

6 Korespondencja. Paryż dnia 1 listopada 1860 roku, „Magazyn Mód i Nowości Dotyczących Gospodarstwa Domowego" 1860, nr 47, s. 2.

7 Por. B. Skarga, Narodziny pozytywizmu polskiego 1831-1864, Warszawa 2013, s. 51.

8 Zob. B. Prus, Nędza zoologicznego ogrodu, w: tenże, Kroniki 1875-1878, Warszawa 1895, s. 131-135.

9 F. Bartels, O potrzebie spożytkowania już istniejacego u nas zamiłowania do zwierząt w celu podniesienia dobrobytu ogółu, Warszawa 1872, s. 3.

10 Tamże, s. 12

11 Tematyka publikowanych przez Kamińskiego rozpraw, w których wysuwał m.in. projekty regulacji pracy seksualnej, wpisywała sie w centralne dla epoki debaty na temat instytucjonalnych ram modernizacji społecznej. J.M. Kamiński, O prostytucji, Warszawa 1870. Na temat zaangażowania pozytywistów warszawskich w kwestię kontroli pracy seksualnej zob. K. Stauter-Halsted, The Devil's Chain. Prostitution and Social Control in Partitioned Poland, Ithaca-London 2015, s. 8.

12 W. Załęski, Rezultaty spisu jednodniowego ludności m. Warszawy z 1882 roku, t. 1, Warszawa 1883, s. 49-55.

13 J.M. Kamiński, Poufna pogadanka o ogrodzie zoologicznym, Warszawa 1885, s. 3.

14 Między nowymi publicznymi instytucjami zoologicznymi, a pozycjonowanymi jako ich antyteza wcześniejszymi formami ekspozycji - zarówno arystokratycznymi, jak i ludowymi - istniała bezpośrednia linia materialnej ciągłości. Gabinet Zoologiczny przy Królewskim Uniwersytecie Warszawskim powstał w oparciu o zbiór eksponatów odkupiony od śląskiego barona Sylwiusza Münkwitza. W następnych dekadach był on sukcesywnie uzupełniany okazami nabywanymi od właścicieli obwoźnych menażerii.

15 F. Bartels, O potrzebie..., s. 5

16 Ogród zoologiczny, "Tygodnik Kucharski” 1884, nr 23, s. 82.

17 Dzięki dotacji z Kasy im. Józefa Mianowskiego - organizacji założonej w 1881 roku w celu finansowego wspierania badań naukowych - Nusbaum-Hilarowicz otworzył w Bagateli niewielki gabinet badawczy. Por. J. Nusbaum, Pamiętnik przyrodnika: autobiografia, Lwów 1921

18 J.M. Kamiński, Poufna pogadanka..., s. 3.

19 W. Dzierzbicki, Na czasie, „Kolarz, Wioślarz i Łyżwiarz: Tygodnik Sportowy llustrowany” 1900, nr 43, s. 6.

20 Ogród zoologiczny, "Nowa Gazeta” 1912, nr 118, s. 1.

21 H. Ritvo, The Animal Estate: The English and Other Creatures in the Victorian Age, Cambridge 1987, s. 213-217.

22 B. Prus, Nędza..., dz. cyt.

23 Indusi, "Kurier Warszawski” 1889, nr 13, s. 3.

24 B.K., Ogród zoologiczny w Warszawie, „Biesiada Literacka” 1884, nr 46, s. 309. 
25 W sprawie ogrodu zoologicznego, „Kurier Poranny” 1890, nr 291, s. 2. Autor felietonu zadał nawet pytanie: „kto bardziej oszalał: czy chłopi z Brazylią, czy Warszawa z ogrodem zoologicznym?".

26 Tamże.

27 Ulokowanie ziem polskich na styku imperialnych i narodowych geografii powodowało, że zwłaszcza Poznań postrzegany był jako konkurencja dla Warszawy. Gdy Ernst Friedl, berliński muzealnik oraz propagator niemieckiej kolonizacji w Azji Wschodniej i na Oceanie Indyjskim, wizytował poznański zwierzyniec w latach 1882 i 1888 - z obydwu pobytów pisząc szczegółowe relacje dla niemieckojezycznego czasopisma fachowego "Der Zoologische Garten" - kontrastował stolicę Provinz Posen, znajdującą się w zasięgu niemieckich wpływów cywilizacyjnych, z gospodarczym i kulturowym zapóźnieniem terenów Królestwa Polskiego. Opisując preżnie rozwijający się zwierzyniec, Friedel charakteryzował Poznań jako miasto „czyste i dobrze prosperujace, na tle brudu i degeneracji Kowna i Wilna, miast polskiej części Litwy, oraz Płocka i Warszawy”. E. Friedel, Der neue Zoologische Garten In Posen, „Der Zoologische Garten. Zeitschrift für Beobachtung, Pflege und Zucht der Tiere" 1883, nr 24, s. 48.

28 Ogród Zoologiczny w Warszawie, „Przyjaciel Zwierząt” 1913, nr 14.

29 Ogród Zoologiczny w Warszawie, „Przyjaciel Zwierząt” 1888, nr 2, s. 7.

30 Por. W. Marzec, Rebelia i reakcja: rewolucja 1905 roku i plebejskie doświadczenie polityczne, Wydawnictwo Uniwersytetu Łódzkiego-Universitas, Łódź-Kraków 2016.

31 Zośka z Bielik, Na straży, "Ster: Organ Równouprawnienia Kobiet Polskich” 1912, nr 9, s. 9-10.

32 Tamże.

33 Por. C. Lansbury, The Old Brown Dog: Women, Workers, and Vivisection in Edwardian England, Madison 1985

34 Z. Kramsztyk, W obronie ogrodu zoologicznego. Odpowiedź "Prenumeratorce”, "Nowa Gazeta” 1909, nr 214, s. 2

35 Głosy te przypominają oskarżenia wysuwane przed rewolucją pod adresem arystokracji i dworu przez środowisko francuskich encyklopedystów. Zob. É. Baratay, E. Hardouin-Fugier, Zoo: A History of Zoological Gardens in the West, London 2004, s. 73.

36 R.Z., Ogród zoologiczny zamiast pomocy ludziom, "Zaranie” 1912, nr 20, s. 429. 


\section{Monika Żółkoś}

\section{Owad i metropolia. Walki świerszczy w obserwacji uczestniczącej Hugh Rafflesa}

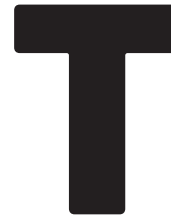

rudno wskazać bardziej znaną antropologiczną narrację na temat widowisk zwierzęcych niż przedstawiona przez Clifforda Geertza analiza walk kogutów na wyspie Bali. Amerykański badacz pokazał, że w charakterze i przebiegu tych starć, aranżowanych regularnie przez balijską społeczność, rezonują kluczowe aspekty wspólnoty. Dotyczą one zarówno prestiżu społecznego i pozycji w grupie, jaką zajmuje opiekun zwierzęcia oraz osoby obstawiające walkę, jak i wyobrażeń dotyczących męskości, której symbolicznym odzwierciedleniem jest gotowy do walki kogut. Spiętrzenie i niejednoznaczność wpisanych w to widowisko antropologicznych tropów jest uderzające. Geertz zauważa, że

[...] choć koguty są rzeczywiście symbolicznym wyrazem i spotęgowaniem jaźni ich właścicieli, Ezopową alegorią narcystycznego męskiego ego, to dla Balijczyków są one również bardziej jeszcze bezpośrednim wyrazem tego, co uznają oni za bezpośrednie przeciwieństwo pod względem estetycznym, moralnym i metafizycznym, tego, co ludzkie: zwierzęcości

Walki kogutów pełnią rolę lustra, czy też raczej, jak pisze Geertz, „społecznego metakomentarza" dla genderowej tożsamości uczestników, a jednocześnie uwikłane są w nierozerwalną antynomię bliskości i obcości, gdyż to, co konstytutywne dla balijskich mężczyzn, odsłania się w porządku zwierzęcym - w tym, co zakazane, wypchnięte, nieoswojone. Geertz ukazuje walki kogutów jako widowisko, z którego wyłania się wpisana w dyskurs podobieństwa i różnicy relacja ludzkie-zwierzęce. Kategorie, które tworzą się każdorazowo w „tu i teraz” społecznego spektaklu.

Relacja splatająca porządek biologiczny i społeczny wydaje się wykładnią wszystkich widowisk zwierzęcych obejmujących tak różne spektakle, jak corrida, rodeo, polowania, występy cyrkowe, pokazy w zoo i oceanariach, a wreszcie walki zwierząt, które same w sobie tworzą niejednolity oraz bardzo szeroki wachlarz działań performatywnych. Obok wspomnianych już walk kogutów na Bali warto przywołać starcia tych zwierząt w Indonezji i Wenezueli, walki koni w niektórych prowincjach Chin, walki psów, niegdyś popularne w wielu miejscach globu (dziś wciąż legalne w Japonii i Hondurasie), a nawet walki pająków, organizowane obecnie na Filipinach, w Japonii i Singapurze. Widowiska zwierzęce mogą mieć bogatą strukturę symboliczną - co pokazał 
w swoim słynnym eseju o tauromachii Michel Leiris ${ }^{2}$ - ale nieodmiennie pozostają pewną narracją o naturze, opartą na antropocentrycznym pęknięciu między człowiekiem a pozaludzkimi formami życia. Istotą tak zorganizowanej walki zwierzęcej jest scena starcia, często krwawa i kończąca się śmiercią jednego z „zawodników”, której człowiek nie ogląda w środowisku naturalnym, ale aranżuje ją w przestrzeni społecznej, przez co staje się ona swego rodzaju laboratorium zintensyfikowanych relacji wewnątrz-, a niekiedy nawet międzygatunkowych (podczas organizowanych w starożytnym Rzymie venationes zmuszano do walki zwierzęta, które nie spotykały się w środowisku naturalnym, jak nosorożce i niedźwiedzie) $)^{3}$.

Trudno oprzeć się poczuciu, że widowiska te - w całej swej różnorodności - służą wytwarzaniu opozycji ludzkie-zwierzęce; arena staje się domeną zwierzęcości, terytorium ludzi wyznaczane jest przez granicę widowni, bezpieczną pozycję spektatora i przynależny mu przywilej patrzenia. Jak dobitnie pokazała w książce Looking at Animals in Human History Linda Kalof, wzrok jest zmysłem, który odgrywa szczególną rolę w historycznie zmiennych sytuacjach spotkania ludzkie-zwierzęce ${ }^{4}$. Człowiek jest tym, który patrzy; zwierzę staje się obiektem jego oglądu. W tej narracji zwierzęcość ukazana zostaje jako istnienie służące „wzrokowej przyjemności”. Dlatego zdarzenia, w których to zwierzę ogląda człowieka - by przywołać tylko fragment Dziennika Witolda Gombrowicza, gdzie pisarz staje oko w oko z krową ${ }^{5}$, czy filozoficzny wywód Jacques’a Derridy Zwierzę, którym więc jestem, inicjowany sceną przyglądania się nagiemu filozofowi przez jego kotkę ${ }^{6}$ - rozszczelniają antropocentrycznie zorientowane narracje. Są prowokacją wobec takich reprezentacji zwierzęcości, które przedstawiają ją jako materię podporządkowaną władzy ludzkiego spojrzenia. W tym ujęciu patrzenie staje się złożoną praktyką społeczną, w której krzyżują się ze sobą ścieżki naukowego poznania, przyjemności i dominacji. Sam akt oglądu jest zarówno legitymizacją władzy człowieka nad światem naturalnym, jak i formą jej sprawowania. Zwierzęcość okazuje się tym, na co nie tylko można, lecz także warto patrzeć; kondycją, którą dookreśla dyskurs egzotyki i niezwykłości. Jak piszą Linda Kalof i Amy Fitzgerald, autorki antologii The Animals Reader:

[...] My, ludzie, zawsze interesowaliśmy się teatrem świata naturalnego, a w szczególności walkami zwierząt, wzmacniając w sobie przekonanie, że są ze swej natury drapieżne i agresywne. Dużo mniej pociągają nas obrazy zwierzęcej zabawy i figlarności. [...] Wizja zantagonizowanej natury obecna jest już w sztuce Mezopotamii, która pokazuje ciągłą walkę między światem przyrody i cywilizacji. Nie bez powodu najwcześniejszy poemat epicki poświęcony jest walce pomiędzy „naturą” (Enkidu) a „kulturą” (Gilgamesz) ${ }^{7}$.

Jeśli czytać aranżowane walki zwierząt jako ukrytą opowieść o relacji między społecznym i naturalnym, to trudno nie zauważyć, że w jej ramach wytwarzana jest wizja zwierzęcości jako czystej agresji: drapieżnej, popędowej siły, którą człowiek może, a wręcz powinien okiełznać. Ramy widowiska stają się formą społecznej kontroli drapieżników ${ }^{8}$

Walki świerszczy są organizowane w Chinach od ponad tysiąca lat; początki tej tradycji sięgają panowania dynastii Tang, która rządziła między VII a X wiekiem naszej ery. Jest to jedno z najstarszych chińskich widowisk zwierzęcych. Jak pisze Andrew Jacobs w artykule Chirps and Cheers: China's Crickets Clash, w pierwszym okresie popularyzacji walk świerszczy inicjowano je wyłącznie dla przyjemności arystokracji, jednak po pewnym czasie stały się popularne wśród szerszych kręgów społecznych ${ }^{9}$. Stopniowo wokół tego widowiska wytworzyła się odrębna praktyka kulturowa obejmująca techniki zbierania owadów, ich hodowania i tresowania, a także skomplikowana siatka pojęciowa, której podstawą jest napięcie między ludzkim a zwierzęcym i ruch znaczeń wytwarzających te dwie kategorie.

W chińskich walkach świerszczy splot porządku naturalnego i społecznego wymyka się dualistycznemu obrazowaniu. Hugh Raffles, autor pionierskiej pracy poświęconej relacjom ludzi i owadów zatytułowanej Insectopedia, opisuje to widowisko jako praktykę wrośniętą w kulturę Chin, a jednocześnie ulegającą przeobrażeniom pod wpływem zachodzących w tym społeczeństwie zmian. „Areną walk świerszczy - zauważa Raffles - stały się wielkie miasta, Pekin i Szanghaj. W Qibao, dzielnicy Szanghaju, odbywają się coroczne festiwale poświęcone pojedynkom tych owadów, mieści się tu również muzeum zwane «Domem świerszczy», w którym zebrano 
kolekcję upamiętniającą tysiącletnią historię widowiska"10. Procesy unowocześnienia uczyniły z Szanghaju miasto wychylone w przyszłość, poddawane ciągłym przemianom modernizacyjnym, ale też politycznej korekcie, której symbolem pozostają relokacje mieszkańców ubogich dzielnic podczas przygotowań do EXPO 2010. W wyniku gwałtownych przeobrażeń urbanizacyjnych w ciągu zaledwie dwóch dekad na obrzeżach Szanghaju przestały istnieć zamieszkiwane przez świerszcze pola uprawne. Ich zniknięcie z wielkomiejskiego pejzażu napędziło rynek zbierania owadów w odległych prowincjach - słynna z walecznych okazów pozostaje prowincja Shandong - i sprzedaży ich w specjalnych marketach, gdzie gromadzą się kolekcjonerzy, treserzy oraz sponsorzy widowisk. Oprócz owadów można tu kupić gliniane i porcelanowe dzbanki, w których przetrzymywane są świerszcze, bogaty w wapno pokarm, suplementy i oczyszczoną wodę, różne rodzaje trawy do drażnienia żuwaczek owada, wagi pozwalające precyzyjnie określić jego ciężar (i przyporządkować do konkretnej kategorii) oraz tak zwane pudełka małżeńskie, w których w przeddzień walki samiec kopuluje z podrzuconą mu samicą ${ }^{11}$.

Zamieszczony w Insectopedii opis nie pozostawia wątpliwości, że dla kolejnych etapów widowiska kluczowy jest rytm następujących po sobie miesięcy. Kultura wytworzona wokół walk świerszczy została podporządkowana Trudno oprzeć się wrażeniu, że zamieszczony w Insectopedii opis zawiesza antropocentryczną perspektywę poprzez odwrócenie relacji i odsłonięcie ukrytej zależności. Raffles pokazuje, jak porządek owadziego istnienia przenika i w jakimś sensie destabilizuje strukture miasta. dynamice życia tych owa-

dów. Zamyka się w konkretnych ramach czasowych, od pierwszych tygodni sierpnia do początku października, i dzieli na trzy etapy: okres handlu świerszczami, następnie czas trenowania nabytych owadów i wreszcie kulminacja - ich pojedynki, które mają miejsce we wrześniu. Hugh Raffles zwraca uwagę, że „radosny czas” - tak nazywany jest tu sezon świerszczy - inicjowany jest przez siódme i ostatnie linienie tych owadów, po którym osiągają seksualną dojrzałość oraz pełnię sił, a samce zaczynają wydawać charakterystyczne, wabiące partnerki cykanie ${ }^{12}$. Autor Insectopedii opisuje chiński sezon świerszczy jako czas powszechnej ekscytacji. Miasto staje się zdynamizowane, nacechowane zmiennością, poruszone:

[...] podczas tego okresu Szanghaj nie ma określonego centrum. Gracze są wszędzie tam, gdzie świerszcze. Na rogach ulic grupki mężczyzn tłoczą się wokół prowizorycznie skonstruowanych malutkich aren, przyglądając się owadzim pojedynkom. W gazetach temat świerszczy pojawia się niemal na każdej stronie, od poważnych artykułów po kroniki policyjne. Ożywają domy hazardu, w których obstawia się walki świerszczy, inicjowane są wydarzenia kulturalne i sąsiedzkie zmagania. Sklepy sprzedają wszystkie możliwe akcesoria. Dopóki trwa „radosny czas”, pieniądze płyną, ludzie podróżują, owady krążą. To czas możliwości, nowego otwarcia. Intensywny, ale bardzo krótki. Trwa tyle, ile życie dorosłego świerszcza ${ }^{13}$.

Trudno oprzeć się wrażeniu, że zamieszczony w Insectopedii opis zawiesza antropocentryczną perspektywę poprzez odwrócenie relacji i odsłonięcie ukrytej zależności. Raffles pokazuje, jak porządek owadziego istnienia przenika i w jakimś sensie destabilizuje strukturę miasta. W obrazie poruszonej, skupionej wokół walk świerszczy społeczności, efemerycznej 
i krótkotrwałej, jest coś owadziego, jakby pozaludzkie doświadczenie materii, w którym trwałość oraz stabilność ustępują miejsca metamorfozie i ulotności.

Przedstawiony przez amerykańskiego antropologa obraz walk świerszczy może brzmieć ironicznie w kontekście współczesnych debat nad antropocenem, nową epoką geologiczną, w której działalność człowieka stała się podstawowym czynnikiem decydującym o życiu gatunków, zmianach klimatycznych i procesach przyrodniczych na planecie ${ }^{14}$. Raffles pisze swoją książkę niejako w poprzek ekologicznych narracji, pokazujących głęboki wpływ działalności człowieka na świat zwierząt. Ale nie chodzi mu o proste odwrócenie biegunów i ukazanie sytuacji, w której to owady wpływają na życie miasta, a ich gatunkowe zwyczaje i osobniczy rozwój oddziałują na zachowania jego mieszkańców. Chodzi raczej o zniesienie mocnej opozycji natury oraz kultury, o rozmazanie dualistycznego sprzężenia, o rozbrojenie pojęć społeczne i naturalne jako kategorii stosowanych na użytek antropocentrycznego cięcia, oddzielającego człowieka od reszty świata. Wielu badaczy z kręgu posthumanizmu zwracało uwagę, że zachodnia koncepcja świata naturalnego jako wyodrębnionej od człowieka strefy sprzyja podejściu, które ma zawłaszczający i reifikujący charakter. Takie myślenie o naturze nie tylko wyłuskuje ludzi z porządku przyrody, lecz także przyznaje im nad nią władzę i legitymizuje politykę eksploatacji. Tak rozumiana natura, będąca - jak pisze Monika Bakke - „konstruktem na usługach historycznie zmieniających się ideologii”"15 , została skrytykowana między innymi przez Brunona Latoura, który uwolnił myślenie o relacji porządku naturalnego i kulturowego z dualistycznych opozycji. W Polityce natury nie tylko odrzuca on praktyki separujące naturę od człowieka, lecz także odbiera mu wyłączność sprawstwa, twierdząc, że zdolność do oddziaływania i wchodzenia w relacje jest również cechą świata pozaludzkiego, od zwierząt po przyrodę nieożywioną ${ }^{16}$. Zresztą samo pojęcie antropocenu, żywo obecnie dyskutowane i będące przedmiotem naukowych negocjacji, ustanawia ważną cezurę w problematyzacji terminu natura i właściwie czyni całkowicie anachronicznym taki jej obraz, w którym jest ona postrzegana jako porządek odrębny od człowieka. Dla wielu badaczy bardziej adekwatne do obecnej kondycji planety oraz skali odziaływania na nią praktyk ludzkich byłoby pojęcie postnatury lub postprzyrody ${ }^{17}$. Jak pisze Jedediah Purdy w książce After Nature. A Politics for the Antropocene, „najbardziej radykalnym przejawem antropocenu jest wyzwanie rzucone popularnym wyobrażeniom rozdzielającym człowieka i naturę, które nie są obecnie ani użyteczne, ani zasadne. Z uwagi na to, że kształtujemy wszystko, od górnych warstw atmosfery po głębię morską, nie ma już natury wolnej od wpływu człowieka"18.

Opisane w Insectopedii walki świerszczy są przykładem skomplikowanej relacyjności między człowiekiem i owadem, wobec której kapituluje dyskurs oparty na mocnych opozycjach. Insekty nie poddają się uprzedmiotawiającej konceptualizacji, pozwalającej przypisać je do kategorii związanych z użytecznością oraz funkcjami pełnionymi w ludzkim świecie; nie obsługują emocjonalnych potrzeb człowieka, w większości wypadków nie mają zastosowania gospodarczego ani laboratoryjnego. Co więcej, w potocznych wyobrażeniach wymykają się nawet dyskursowi zwierzęcości, choć nauki biologiczne sytuują tę gromadę stawonogów w królestwie animalitas. A przecież trudno nie zauważyć, że nasze wyobrażenia owadów często biorą udział w kulturowych grach o ludzką tożsamość, by wskazać tylko Przemianę Franza Kafki czy Muchę, filmowe dzieło Davida Cronenberga ${ }^{19}$. Proste opozycje nie znajdują także zastosowania w odniesieniu do chińskich walk świerszczy. Trenerzy i obserwatorzy widowiska wprzęgają te owady we własne praktyki kulturowe, które jednak nie polegają na prostym ich uprzedmiotowieniu. Sprawczość nie jest tu wyłączną domeną człowieka. Raffles podkreśla, że proces trenowania świerszczy jest ukierunkowany na wydobycie przyrodzonych cnót owada i stworzenie warunków, w których naturalne wyposażenie zwierzęcia może się rozwinąć w ducha walki ${ }^{20}$. Tak zwani mistrzowie świerszczy posługują się niezwykle skomplikowanym systemem klasyfikacji, który dzieli owady na siedemdziesiąt dwa typy, biorąc pod uwagę kolor odwłoka, podbrzusza i odnóży, długość całego ciała i osobno czułków, kształt głowy ze szczególnym wyróżnieniem linii biegnących od oczu w kierunku grzbietu, wielkość żuwaczek, a nawet chód, który - jak zaznaczają rozmówcy antropologa - musi być lekki i szybki, bez zataczania się na boki. Znajomość tych wszystkich aspektów owadziej anatomii i fizjologii jest kluczowa dla odnalezienia właściwych okazów na etapie handlu świerszczami. Nawet najsilniejszy owad - a siła jest ważniejsza niż wielkość - nie jest bowiem gotowy do walki, stanowi zaledwie materiał na wojownika, w którego przeistacza się w toku trwającej dwa tygodnie tresury. Składają się na nią zalecenia higieniczne 
i żywieniowe, fizjoterapia, a przede wszystkim zrozumienie psychologii owada oraz umiejętność stworzenia warunków rozwoju, w których - co podkreśla jeden z rozmówców brytyjskiego antropologa - „będzie się czuł kochany”21.

Podstawą tego podejścia do dziś pozostaje napisana w XIII wieku Księga świerszczy, której autor, Jia Sidao, był ministrem pod koniec rządów dynastii Song. Raffles zaznacza, że ta praca - poprzedzająca o trzysta lat pierwsze europejskie książki entomologiczne ${ }^{22}$ - nie wyrasta z pragnienia skatalogowania świata owadów, ale ma charakter czysto praktyczny: zawiera opisy morfologii świerszczy mające pomóc w usprawnieniu widowiska. Dotyczą typów budowy i znaków waleczności wpisanych w anatomię owada, zawierają detaliczne wskazówki pielęgnacyjne, odnoszą się do warunków, w jakich zwierzę powinno się rozwijać. Księga świerszczy jest przejawem praktyki dyskursywnej, w ramach której na zwierzęcość nałożona zostaje złożona siatka pojęciowa nadająca owadom określone znaczenie i hierarchizująca je. To przykład konceptualnego zawłaszczenia, w którym to, co obce i pozaludzkie, zostaje przekute w rozpoznane i oswojone. Jak pokazał w swoim artykule Zwierzę, którym więc jestem Jacques Derrida, gest porządkowania, systematyzacji, a przede wszystkim nadawania nazwy jest dobitnym poświadczeniem pozycji władzy i strategią wytwarzającą antropocentryczne cięcie ${ }^{23}$. Z drugiej jednak strony warto zwrócić uwagę na koncepcję międzygatunkowej komunikacji, która według autora Księgi świerszczy jest niezbędnym elementem przygotowywania „zawodnika” do walki. Liczne wskazówki i uwagi techniczne podporządkowane są imperatywowi wsłuchiwania się w owada, w jego indywidualne potrzeby i konstytucję. „Mistrz świerszcza” powinien umieć odkryć wyjątkowość konkretnego zwierzęcia. Zauważmy, że jest to myślenie stojące w sprzeczności z tradycją Zachodu, w której owady często postrzegane są jako istoty abiektalne, budzące wstręt oraz lęk, rojące się i ukazujące pod postacią pulsującej masy. W chińskim widowisku owady przestają być anonimowe, wielu z nich nadawane są imiona i przydomki wskazujące na niepowtarzalne ich właściwości. Raffles wymienia następujące: Żelazny Grzbiet, Skrzydło Ying Yang, Siłacz, którego nikt nie skrzywdzi ${ }^{24}$. W myśl trzynastowiecznej Księgi świerszczy przygotowanie owada do walki ma być raczej wydobywaniem ukrytych w nim zdolności niż narzucaniem zewnętrznych, sprzecznych z naturą zachowań.

Niezbywalnym elementem widowisk zwierzęcych świata zachodniego jest tresura. To w pełnym tego słowa znaczeniu performanse poskramiania, które albo dzieją się na oczach publiczności, jak w przypadku rodeo czy corridy, albo już się dokonały, a widzowie oglądają sam efekt - potulne, ujarzmione zwierzęta, jak to ma miejsce podczas występów cyrkowych. Tresura jako akt okiełznania natury staje się procesem ustanawiania społecznego porządku nad tym, co żywiołowe i instynktowne. Tak postrzegane widowiska zwierzęce są dobitnym poświadczeniem wyższości człowieka oraz formą naturalizacji jego władzy. Walki świerszczy mocno komplikują ten model. Z jednej strony nałożenie na owady rozbudowanej siatki pojęciowej jest oczywiście formą zawłaszczenia zwierzęcia i wprzęgnięcia go w strukturę symboliczną, z drugiej - chińskie widowisko nie służy poświadczeniu ludzkiej dominacji, nie jest afirmacją prawa do podporządkowywania sobie natury. Człowiek jawi się tu raczej jako istota towarzysząca przemianie świerszcza w wojownika, której fundamentem jest wydobycie i wzmocnienie u owada cech uchodzących w kulturze chińskiej za idealne przymioty ludzkie. Jak twierdzi Master Fang, „mistrz świerszczy”, wtajemniczający autora Insectopedii w tajniki widowiska, gotowy do walki owad odznacza się pięcioma cnotami: wiarygodnością (bo kiedy przyjdzie właściwy czas, na pewno zaśpiewa, zwiastując tym samym rozpoczęcie pojedynku), odwagą (skonfrontowany z przeciwnikiem stanie do walki), lojalnością (nawet ranny, nie wycofa się z bitwy), poczuciem wstydu (pokonany świerszcz nie śpiewa) i mądrością (bo jest w stanie racjonalnie ocenić swoją sytuację) ${ }^{25}$. Taka interpretacja walczących świerszczy nie jest prostą antropomorfizacją, nie służy upodobnieniu zwierząt do ludzi. Owad zdaje się raczej lustrem, w którym człowiek chce się przejrzeć, jest upragnionym wzorcem, inspiracją do przekształcenia samego siebie. Jednak opisane przez Rafflesa wyobrażenia na temat świerszczy są w jakimś sensie pęknięte, nacechowane ambiwalencją. Dyskurs bliskości, w którym spotyka się świat ludzki i owadzi, zostaje skontrowany przymiotami świerszczy, które gruntownie odróżniają je od człowieka. Mister Fang wskazuje na trzy przeciwieństwa: pierwsze - pokonany owad odchodzi bez skargi i żalu; drugie - aktywność seksualna tuż przed walką sprzyja pobudzeniu sił żywotnych; trzecie - świerszcze kopulują w pozycji, w której samica znajduje się na grzbiecie 
samca ${ }^{26}$. Zarówno podobieństwa, jak i różnice są w tych wyobrażeniach nierozerwalnie ze sobą sprzęgnięte. Z ich połączenia wyłania się narracja, która ciąży ku antropomorfizmowi, a jednocześnie ten typ wyobrażeń zawiesza: „Pięć cnót odsłania głęboki, ontologiczny związek między ludźmi a świerszczami, wielowiekowe współistnienie, oparte na przywiązaniu i identyfikacji [...]; trzy przeciwieństwa wskazują na odmienny stan rzeczy, na głęboką przepaść rozdzielającą człowieka i owada"27.

Raffles podkreśla, że walki świerszczy mają bardzo gwałtowny przebieg. Zawodnicy umieszczeni zostają naprzeciwko siebie i cała widownia czeka w napięciu na ich dźwięki. Dopiero kiedy świerszcze zaczynają cykać, sędzia daje znak, że pojedynek może się rozpocząć. Owady najpierw zamierają, a następnie gwałtownie rzucają się na siebie. Ich starcie jest żywiołowe, niemal spazmatyczne. Amerykański antropolog opisuje niezwykłą intensywność walki, którą oglądał na żywo. Była ona dla niego eksplozją przemocy ${ }^{28}$. Starcie kończy się równie nieoczekiwanie, jak się zaczyna. Gdy jeden z owadów wycofuje się albo zostaje przewrócony, uznaje się go za pokonanego. Nigdy więcej nie wystawia się go do walki, bo mogłoby to oznaczać zranienie lub śmierć. Zostaje wypuszczony. Bezkrwawy finał widowiska w zestawieniu z jego gwałtownością budzi poczucie dysonansu. W tym krótkim starciu owadów spełniają się długie tygodnie przygotowań. Wszystkie starania i nadzieje zostają sprowadzone do kilku minut walki, poddane rytmowi owadziego sprzężenia oraz odpuszczenia, nagłego ataku i równie nagłej rezygnacji.

Może właśnie ambiwalencja najlepiej oddaje zmieniającą się rolę walk świerszczy w kulturze współczesnych Chin. Przejawem tego jest pęknięcie w społecznym postrzeganiu i celebrowaniu spektaklu. Przez niektórych Chińczyków walki świerszczy uważane są za aktywność duchową, w której odbijają się fundamentalne wartości ich kultury. Inni pasjonują się tym widowiskiem jako praktyką hazardową, stawiając na wybrane owady całkiem pokaźne sumy ${ }^{29}$. W dialekcie szanghajskim świerszcz to cai ji, co znaczy „gromadzenie fortuny”. Zwolennicy uwznioślenia walk świerszczy i oderwania ich od profitów finansowych twierdzą, że hazard degeneruje to widowisko oraz przyczynia się do jego upadku. Obecne w Insectopedii poczucie nostalgii, wrażenie obcowania z przemijającą formą kultury, wzmacniane jest przez fakt, że walki świerszczy kultywuje generacja urodzona pod koniec rewolucji kulturalnej, podczas której widowisko to było zakazane. Po jej zakończeniu nastąpił renesans zainteresowania pojedynkami świerszczy, które jednak nie znajdują upodobania wśród młodego pokolenia. Raffles zwraca też uwagę na genderowy wymiar widowiska ${ }^{30}$. Podobnie jak w przypadku walk kogutów na Bali w pojedynki świerszczy angażują się niemal wyłącznie mężczyźni. Podrzędna rola samic, które sprzedaje się w innym obiegu rynkowym razem z akcesoriami służącymi stymulacji samców przed walką, oraz militarna metaforyka czynią z walk świerszczy coś w rodzaju szkoły męskości; pochyleni nad pojedynkami owadów widzowie oglądają zintensyfikowaną rolę płciową, spełniającą się w pięciu bojowych cnotach.

Chińskie walki świerszczy nie poddają się łatwo problematyzacji. Sama idea walk zwierząt, która staje się wielopoziomowym lustrem dla społecznych praktyk człowieka, zdaje się formą opisanej przez Derridę dyskursywnej przemocy ${ }^{31}$. Jednocześnie jednak chińskie widowisko zwierzęce wyraźnie wyłamuje się z dualistycznego ujęcia, przywołuje wizję obdarzonej sprawczością i upodmiotowionej natury. Okazywany owadom szacunek, tresura oparta na wydobywaniu przyrodzonych przymiotów zwierzęcia, deklarowana przez „mistrzów świerszczy” wrażliwość na indywidualny charakter każdego owada budują sytuację ludzko-zwierzęcego współbycia. Obraz wspólnoty niepełnej, niedoskonałej, chwilowej - ale może jedynej, jaka jest możliwa? 


\section{PRZYPISY}

1 C. Geertz, Głęboka gra: walki kogutów na Bali, przeł. G. Godlewski, „Dialog” 2005, nr 7-8, s. 90

2 Zob. M. Leiris, Lustro tauromachii, przeł. M. Ochab, Gdańsk 1999.

3 Zob. G. Jennison, Animals for Show and Pleasure in Ancient Rome, Philadelphia 2005; D. Słapek, Venationes republiki rzymskiej. Sacrum czy profanum?, w: L. Kostuch, K. Ryszewska (red.), Zwierzę jako sacrum w pradziejach i starożytności, t. 2, Kielce 2006.

4 Zob. L. Kalof, Looking at Animals in Human History, London 2007

5 W. Gombrowicz, Dziennik 1957-1961, Kraków 1986, s. 34

6 J. Derrida, The Animal That Therefore I Am, przeł. D. Wills, New York 2008, s. 3-4.

7 A. Fitzgerald, L. Kalof (red.), The Animals Reader. The Essential Classic and Contemporary Writings, New York 2007, s. 247

8 Więcej na ten temat piszę w jednym z artykułów. Zob. M. Żółkoś, Teatr zwierzęcej śmierci, „Didaskalia” 2014, nr 119.

9 A. Jacobs, Chirps and Cheers: China's Crickets Clash, "New York Times”, 5.11.2011, https://www.nytimes. com/2011/11/06/world/asia/chirps-and-cheers-chinas-crickets-clash-and-bets-are-made.html (dostęp: 5.05.2018).

10 H. Raffles, Insectopedia, New York 2010, s. 76

11 Zob. tamże, s. 87-88.

12 Tamże, s. 87.

13 Tamże, s. 93-94

14 Najciekawszą pracą na ten temat w polskiej (post)humanistyce jest książka Ewy Bińczyk, która pokazuje historyczne i współczesne konteksty zjawiska, zbierając najważniejsze dyskursy powstałe wokół hipotezy o nowej epoce geologicznej. Zob. E. Bińczyk, Epoka człowieka. Retoryka i marazm antropocenu, Warszawa 2018.

15 M. Bakke, Bio-transfiguracje. Sztuka i estetyka posthumanizmu, Poznań 2012, s. 58-59.

16 Zob. B. Latour, Polityka natury. Nauki wkraczaja do demokracji, przeł. A. Czarnacka, Warszawa 2009.

17 Zob. E. Bińczyk, Epoka człowieka..., dz. cyt., s. 118.

18 J. Purdy, After Nature. A Politics for the Anthropocene, London 2015, s. 4.

19 Więcej na temat problematycznej obecności owadów w dyskursie animal studies pisze w tekście Mikro-formy i makro-lęki... Zob. M. Żółkoś, Mikro-formy i makro-lęki. Owady jako wyzwanie dla animal studies, w: A. Barcz, D. Łagodzka (red.), Zwierzęta i ich ludzie. Zmierzch antropocentrycznego paradygmatu?, Warszawa 2015, s. 34-45. Na temat kulturowych wizerunków owadów w perspektywie posthumanistycznej zob. A. Dodd, Minding Insects: Scale, Value, World, w: R.H. Lemelin (red.), The Management of Insects in Recreation and Tourism, Cambridge 2012; A. Dodd, Size is in the Eye of the Beholder: On the Cultural History of Microfaunae in Seventeenth-Century Europe, w: K. Aukrust (red.), Assigning Cultural Values, Frankfurt 2013; J. Parikka, Owady i media, przeł. M. Borowski, M. Sugiera, Kraków 2017; C. Hollingsworth, Poetics of the Hive. The Insect Metaphor in Literature, lowa 2001; E.C. Brown (red.), Insect Poetics, London 2006.

20 H. Raffles, Insectopedia, dz. cyt., s. 98.

21 Tamże, s. 82

22 Entomologia jako zinstytucjonalizowana nauka narodziła się w XIX wieku razem z pracami Williama Kirby'ego oraz Williama Spence'a, którzy wspólnie wydali czterotomowe dzieło Introduction to Entomology (1815-1826). Niemniej pierwsze naukowe prace poświęcone owadom zaczęły powstawać już w XVI wieku. Jednym z prekursorów był ilustrator Joris Hoefnagel, autor The Four Elements, książki poświęconej światu zwierzecemu, w której owady zajmują znaczące miejsce. Innym ważnym badaczem, który przetarł w zachodniej nauce ścieżke entomologii, był Thomas Moffet, autor pracy Insectorum sive minimorum animalium theatrum (1634). Na temat początków europejskiej entomologii, w szczególności dzieła Moffeta, zob. M. Żółkoś, Teatr owadów, "Didaskalia” 2019, nr 153.

23 J. Derrida, The Animal..., dz. cyt., s. 32.

24 Zob. H. Raffles, Insectopedia, dz. cyt., s. 84

25 Tamże, s. 78.

26 Tamże, s. 114

27 Tamże.

28 Zob. tamże, s. 100

29 Zob. A. Jacobs, Chirps and Cheers..., dz. cyt.

30 H. Raffles, Insectopedia, dz. cyt., s. 93.

31 J. Derrida, The Animal..., dz. cyt., s. 61. 


\section{Osy zaraz po wojnie. Owady na miejskim marginesie: realizm i widzialna obecność}

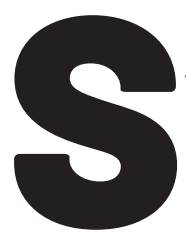

ytuacja finansowa Szczęsnego po opuszczeniu warsztatu stolarskiego majstra Czerwiaczka na Lesznie i przeniesieniu się do specjalizującego się w podrabianiu oraz poprawianiu mebli antycznych zakładu Wierzbickiego na Podwalu zmusiła go do zamieszkania na Starym Mieście. Znalazł się „w małej, pleśnią pociągniętej kamieniczce zwanej «Pekinem», u wylotu wąskiej ulicy z widokiem na Rybaki i Wisłę"1. Kamieniczka pozbawiona była wygód, nie było w niej prądu, miała wspólny wychodek. Lokale były przepełnione, a mieszkali w nich między innymi zbieracz butelek, tramwajarz, warzywiarka, wdowa po sterniku z „Vistuli”. Zaułek, w którym znalazł się bohater, zamieszkują jeszcze w Pamiq̨tce z Celulozy recydywiści i Chińczycy domokrążcy produkujący galanterię, stąd zapewne wspomniana nazwa rudery. W wolnych chwilach Azjaci grają w „karalucha”, wraz z Zochą, kochanką Szczęsnego, jesteśmy świadkami partii:

Chińczycy ustawili się dookoła stołu w równych odstępach, trzymając na krawędzi maleńkie pudełeczka jak do zapałek, oklejone zielonym papierem z czarnymi znaczkami na wierzchu.

Lituńczak cicho gwizdnął. Na to hasło gracze błyskawicznym ruchem wyrzucili z pudełek po karaluchu. Karaluchy pobiegły na wyścigi do monet, a spotkawszy się zaczęły się bić. Stół zamienił się w pole walki. Od czasu do czasu wyciągały się ręce z długimi paznokciami, chwytały monetę bezszelestnie - szeleściły tylko karaluchy po stole. Ta cisza dławiła. Żeby choć jeden odezwał się, coś zawołał! Ale usta graczy były zaciśnięte, twarze skamieniałe, tylko oczy płonęły coraz mocniej i ciemniejsze plamy wypieków występowały na zapadniętych policzkach -i to wszystko po stokroć bardziej podniecało niż wszelki hazard, jaki dotychczas Zocha widziała w kinie.

Szczęsny wytłumaczył jej, że gdy karaluch wywalczy sobie drogę do pieniędzy, to jego właściciel zabiera wszystko, na czym to obrzydlistwo stanie - monetę albo górkę, czyli cały „szan”2. 
Na pytania ciekawskiej Zochy Szczęsny odpowiada o sposobach trenowania owadów-główną tajemnicą jest trzymanie w pudełku i głodzenie, które sprawia, że karaluch na forsę leci. „To samo, co się robi ze złodziejem" - dodaje Szczęsny3. Mówi również, że Azjaci grają dość rzadko (najwyżej raz w miesiącu) i że głównym motorem napędowym tych zawodów hazardowych jest dla nich nostalgia. Pojawia się przy tym porównanie właścicieli do ich zawodników, jedzą oni bowiem „prawie tyle co karaluch”.

Powieść Newerlego jest realistyczna, jej akcja toczy się w latach 30. XX wieku. Chińczycy żyjący z handlu domokrążnego według prasy dwudziestolecia rzeczywiście pojawiają się na warszawskiej Starówce, chociaż to Mostowa miała być główną ulicą ich zamieszkania5 O króciutkiej, ślepej Samborskiej milczą w tej sprawie źródła, które dotychczas znalazłem, a tak naprawdę nie mają o niej za dużo do powiedzenia ${ }^{6}$. Sama nazwa ulicy pada w powieści zresztą dopiero pod koniec tego epizodu, jakby od niechcenia. We wspomnieniach Zygmunta Aksienowa, urodzonego w 1930 roku i mieszkającego jako dziecko na tejże ulicy, Samborska jawi się jako przeludniona, pełna dość biednych, pracujących fizycznie ludzi, o Chińczykach jednak nie ma tam ani słowa ${ }^{7}$. Być może epizod z karaluchami należy dostrzec w kilku kontekstach, na przykład orientalnych fascynacji Newerlego, które zaowocują w późniejszym okresie powieściami z akcją rozgrywającą się na Syberii (Wzgórze błękitnego snu) i w Mandżurii (Leśne morze), czy w metodzie pisarskiej autora, chętnie określającego siebie jako kogoś „między detektywem a złodziejem", tworzącego w konwencji realizmu, który nie utożsamia się ze średniością i z szarością, nie boi się jaskrawych plam, zmysłowych doznań oraz inności widzenia, toteż musi się mierzyć z oskarżeniami o egzotyzm, naturalizm czy impresjonizm ${ }^{8}$. Niezależnie od sporów estetycznych z początku lat 50. egzotyczny posmak całej sytuacji opisywanej w Pamiątce z Celulozy jest dotkliwie odczuwalny. Chociaż rzeczywiście Szczęsny zdaje się traktować i opisywać wszystko to jako oczywiste, to ekscytacja Zochy bierze górę. Pomijając porównanie potrzeb żywieniowych, samo zestawienie Chińczyków z owadami wzmacnia odmienność czy osobliwość obu grup. Podobnie jest z przenośnią karalucha jako złodzieja zamkniętego w więzieniu.

To zamknięcie jest kluczowe dla postrzegania owada w ogóle, dzięki niemu staje się on rzeczywistym przedmiotem zagrożenia, obrzydzenia, ale i zdwojonej uwagi czy właśnie fascynacji. Aleksander Wat wspomina w Moim wieku swoje obserwacje pluskiew z więzienia w Saratowie. Można powiedzieć, że jest to sytuacja przypominająca warunki laboratoryjne: w celi można obserwować współwięźniów, powtarzać pamiętane przez siebie zdania i formuły, opowiadać sobie wzajemnie historie, medytować nad sobą oraz innymi, podnosić dyskretnie „kruszynę chleba” w drodze na spacerniak. O tym wszystkim jest mowa w „mówionym pamiętniku” Wata; można też zwrócić uwagę na zachowania tych nieprzyjemnych owadów, zamkniętych wraz z ludźmi, porównywać je z pluskwami z innych więzień, studiować ich „psychikę”. Jednocześnie oczywiście trzeba je niszczyć, palić żywcem. To więźniowie stają się we wspomnieniu poety prześladowcami pasożytów, które nie robią ludziom wielkiej krzywdy, nie smakuje im ich krew, być może jest za bardzo rozwodniona - podejrzewa Wat. Owady stają się w tej opowieści wehikułem nawrócenia, niosą ze sobą ładunek niemal mistyczny, a na pewno filozoficzny. Ich inność zdaje się potwierdzać istnienie Boga, który musi istnieć, by znać ich sekret, a z pewnością poświadczają immanentne zło tkwiące w człowieku.

To zamknięcie owadów, które można rozumieć na wiele sposobów, wywołuje często konieczność podjęcia z nimi walki, ale drugą stroną tego medalu jest możliwość znęcania się nad nimi, bezmyślnego ich zabijania. Miejski zaułek zdaje się związany z owadami jakąś intymną relacją. W naturalistyczno-realistycznym tekście Wiktora Gomulickiego opublikowanym w „Kurierze Warszawskim” w 1874 roku autor odmalowuje w jednoznacznie czarnych barwach ślepą warszawską uliczkę w jej wczesnej, wielkokapitalistycznej formie. Jest to portret zaułka uogólniony, ale nie brak w nim detalicznych opisów. Takie miejsce cechują: brak ciszy, bałagan budowlany, rachityczna zieleń w postaci obdartej akacji, zaludniają zaś na stałe typowi bohaterowie: żebrak i bawiący się ze sobą ulicznicy. Jeden z nich, opisywany z ironią przez Gomulickiego, dręczy szczypawki: „trzeba widzieć, z jakim wysiłkiem podnosi kamienie nagromadzone w kącie zaułka i z jakim trudem nadziewa na tępą szpilkę wijącego się owada, ażeby dokładnie zrozumieć i ocenić jego gorącą miłość prawdy i nauki” ${ }^{10}$. Jest coś podwójnie nieprzyjemnego w tym obrazie i nie da się go zamknąć w formule puszczonego bez kontroli młodzieńca czy dziecka, które żywemu nie przepuści. Przypomina o obojętności ludzi wobec 
świata dziecięco-młodzieżowej przemocy, ale równocześnie sugeruje, że dochodzenie do wiedzy często oznacza torturowanie zwierząt.

Pozycja owadów w ludzkiej przestrzeni, a co za tym idzie - również w ludzkich narracjach, w imaginarium - jest dziwna i specyficzna, co było nieraz stwierdzane. Monika Żółkoś dokonała przeglądu tych różnych stanowisk lokujących owada poza podstawowymi ludzko-zwierzęcymi podziałami: nie są „ani udomowione, ani dzikie”, swobodnie przekraczają bariery odgradzające je od ludzi, choć są istotami niepożądanymi, abiektami, są bardzo blisko człowieka, a przecież są największą widzialną obcością w świecie zwierząt itd. ${ }^{11}$. Owady w mieście, a co za tym idzie - owady w narracjach dotyczących miasta - funkcjonują na jeszcze bardziej specjalnych prawach, na podwójnym marginesie. Z jednej strony jeszcze bardziej niechciane, gdy stają się intruzami, naruszając mir domowy, z drugiej jeszcze mniej zauważane. Miasto, zwłaszcza nowoczesne, to środowisko, które ma być odporne na zmienność przyrody pozostającej pod cywilizacyjną kontrolą. Zwierzęta zajmują w nim określoną niszę. Owady są tutaj oczywistością jako ludzkie pasożyty, które trzeba zlikwidować, a pozytywna strona ich istnienia jest rzadziej dostrzegana. Nawet tym nielicznym „dobrym” trudno się przebić do świadomości włodarzy czy mieszkańców miast. Miejskie pasieki, które są

Owady w mieście, a co za tym idzie owady w narracjach dotyczacych miasta - funkcjonuja na jeszcze bardziej specjalnych prawach, na podwójnym marginesie. Z jednej strony jeszcze bardziej niechciane, gdy stają się intruzami, naruszając mir domowy, z drugiej jeszcze mniej zauważane. ważną modą w ostatniej dekadzie w Polsce, stanowią dobry przykład wyjątku potwierdzającego regułę. Aby owady znalazły się w polu widzenia i uwagi mieszkańców miast, musi zdarzyć się „coś”. Najczęściej - poza jednostkowym wtargnięciem - jest tym ich widzialna nadobecność: „Pamiętam jak we wrześniu, w Paryżu, w latach zaraz po wojnie, było dużo os, o wiele więcej, wydaje się, niż obecnie”12. W zdaniu Georges’a Pereca pojawiają się owady codzienne w swojej niezwyczajnej postaci, która wryje się w pamięć pisarza na tyle, że po latach wspomnienie to zostanie przywołane i zapisane w książeczce, której projekt wykraczał poza horyzont osobisty, a miał być zaproszeniem do intersubiektywnej biografii pewnego pokolenia dorastającego w określonym miejscu. Jednocześnie Perec pisze: „wydaje się”, więc nie jest pewien, jest to sfera szczególnie narażona na niepamięć, subiektywizm, niepewność. Zdanie to jako jedno z niewielu nieopatrzone zostało przypisem z komentarzem polskiego tłumacza (odwołującego się do zgromadzonej wiedzy oraz do komentarzy francuskich), nie udało się więc nadmiarowej obecności os zweryfikować.

Jasne, że zwykle ta nadobecność jest łatwiejsza do stwierdzenia, gdy wywołuje strach przed owadami uważanymi za niebezpieczne czy nieprzyjemne (tak jak być może w przypadku os Pereca), w każdym razie w powszechnej świadomości zagrażające człowiekowi. W czerwcu 2019 roku po ciepłej i wilgotnej pogodzie pojawiły się w Warszawie komary, nieco liczniejsze w powszechnym odczuciu niż zwykle. Stały się więc przedmiotem lekkiego przerażenia ludzi, podsycanego, jak zwykle w takich przypadkach, przez publikacje prasowe - tutaj już przede wszystkim w wersji elektronicznej. „Pani Jadwiga opisała nietypową sytuację w tramwaju linii 17, którym jechała we wtorek około godziny 19.30 w kierunku Tarchomina. Na przystanku przy Lasku Bielańskim do pojazdu «wsiadły» komary. «Przez otwarte drzwi wdarły się do wnętrza pojazdu setki owadów, budząc popłoch wśród pasażerów» - pisze kobieta” - donosiła „Gazeta.pl”. Natomiast pod publikacją zatytułowaną trójdzielnie Komary w Warszawie. Do tramwaju wdarły się setki komarów. „Pasażerowie próbowali w panice uciekać” pojawiły się, 
jak zwykle w podobnej sytuacji, posty nie tylko bagatelizujące przeżycia mieszkańców i - jeszcze wyraźniej - mieszkanek (to kobiety przecież głównie histeryzują na widok owadów!), lecz także wyrażające sprzeciw wobec postulatów nawołujących do chemicznej eksterminacji tych krwiożerczych zwierzą ${ }^{13}$. Czytelnicy świadomi ekologicznych powikłań, do jakich mógłby doprowadzić oprysk, wsparci głosem eksperckim w artykule, protestowali na szczęście zdecydowanie. Nareszcie także komary trafiły do debaty politycznej nad wotum zaufania dla prezydenta miasta Rafała Trzaskowskiego, a radni z opozycyjnego klubu nie wahali się użyć ich jako argumentu przeciwko władzy, która nie zabezpiecza odpowiednio mieszkańców i nie chce stosować oprysków ${ }^{14}$. Słowa „plaga”, „chmara”, „popłoch” dobrze określają ten nieoczekiwany naddatek, jaki w oczach człowieka cywilizowanego, mającego prawo do poczucia bezpieczeństwa w jadącym przez miasto tramwaju, wywołują owady w zauważalnej liczbie. Popkulturowym wyrazem tych lęków są horrory i filmy katastroficzne, ze zrealizowanym w gwiazdorskiej obsadzie Rojem Irwina Allena (1978) na czele - symptomatyczne i nazbyt przejrzyste, że prawdziwe zagrożenie stanowią ukazane w nim zabójcze pszczoły, gdy zaatakować mają duże amerykańskie miasto (Houston).

Jeśli nie działają w roju, w nagromadzeniu, to efekt poczynań tych małych zwierząt polega na tkwiących w nich anegdotycznych niemal zdolnościach do nadzwyczajnych skoków, lotów, siłowania się z przeciwnikiem itp., przekraczających wyobraźnię człowieka przyzwyczajonego do możliwości zwierząt kręgowych. Te umiejętności są słabo uchwytne dla ludzkiej percepcji i do dziś trudne do eksponowania, do ukazania w akcji szerszemu audytorium, nie mówiąc o problemach z ewentualną tresurą owadów. Oczywiście współcześnie można je powiększyć, pokazać w odpowiednim dla ludzkiego oka formacie. Przed pawilonem bezkręgowców warszawskiego zoo stoją (luty 2020) przekraczające wielkością człowieka: pasikonik, komar, pająk, mrówka, osa i chrząszcz, na które nie wolno niestety siadać - możliwe, że te figury są dla większości odwiedzających bardziej atrakcyjne niż zgromadzone w pawilonie egzotyczne pająki, wije i karaczany (na piszącym te słowa największe wrażenie zrobiły karaczany tureckie, które przechadzają się po terrarium stylizowanym na wnętrze kuchenne, co wywołuje efekt wtargnięcia insekta; scenografia, jakiej się w zoo nie spodziewamy). Takie parki owadów gigantów, swoistych antyminiatur spotkać można obecnie w różnych umiejscowieniach, na przykład w wariantach mikro w sąsiedztwie lasów, często w miejscowościach mniejszych i wypoczynkowych, jako lokalna atrakcja rozrywkowa dla dzieci oraz turystów (w Polsce między innymi w pasie Podkarpacie-Małopolska: w Zatorze, w Wapowcach koło Przemyśla, oraz w pasie pojezierzy: w Starych Juchach na Mazurach, w Krągach koło Bornego Sulinowa, w Lubnicy pod Szczecinkiem). Przy okazji mogą one służyć wzbudzeniu dziecięcego zainteresowania owadami, ale jednocześnie swoistej gettoizacji, myśleniu o nich jako o istotach, dla których właściwym miejscem jest przestrzeń niezurbanizowana, wyłączona. Historycznie jednak takich urządzeń w postaci gigantoparków nie było, a na przykład cyrk opierał się na występach żywych zwierząt; z powodu wspomnianych wyżej trudności niełatwo było wprowadzić do niego owady. Jednocześnie możliwość przełamania tych trudności jest (czy raczej była) szczególnie efektowna, jak choćby w przypadku cyrków pcheł: widowisk wykorzystujących wyjątkowe zdolności tych zwierząt. Ważnym ich elementem jest napięcie między widzeniem a niewidzeniem będące spiritus movens przedstawienia $^{15}$, które, jak ujmuje to jedno z ogłoszeń z 1877 roku, „widzieć można bez aparatów”16. Poruszająca niewidoczność nie wyklucza bowiem możliwości obserwowania owadów przez lornetki, dzięki czemu widzimy, kto jest za ten ruch odpowiedzialny. Innym zastanawiającym przykładem byłby przypominany przez Aleksandra Łupienkę połykacz pluskiew, za niewielką opłatą zjadający je z chlebem. Miał on być oryginalną atrakcją podwórek - tak wynikałoby ze świadectwa Eryka Justa, na którym oparta jest informacja badacza dziewiętnastowiecznych warszawskich kamienic ${ }^{17}$. Ten nieco szokujący performans - oglądamy za oknem obrzydliwego owada, którego znamy codziennie z naszych tapet i łóżek, w nietypowej dla niego roli - wskazuje, że uwidocznienie rzeczywistych owadzich możliwości w równym stopniu co przełamanie dotyczącego ich stereotypu jest zwykle związane z teatralizacją, niezależnie od jej inscenizowanego czy też nieinscenizowanego charakteru ${ }^{18}$.

Swego rodzaju dopełnieniem kłopotów nowoczesnego człowieka metropolii z nadobecnością owadów (i pokrewnych im pajęczaków) jest wypuszczenie go poza bezpieczną przestrzeń cywilizacji, gdzieś, gdzie czai się właśnie groza robactwa. W literaturze pięknej często 
pokazywany jest on dla celów satyryczno-humorystycznych. Thomas Bernhard ukazuje w ten sposób jednego z bohaterów swojej dramoletki z lat 80. XX wieku ośmieszającej środowisko wiedeńskiego teatru miejskiego; czyni to zresztą w didaskaliach. „Naturalnie rozumiem pana”mówi naczelny dramaturg Hermann Beil do dyrektora Burgtheater Clausa Peymanna, gryząc kawałek sznycla, ale „równocześnie wzdryga się ze strachu przed kleszczami, ponieważ wie, że na Sulzwiese są miliony kleszczy, które wżerają się w ciało człowieka, powodując zapalenie opon mózgowych"19. Wyprawa do niezbyt oddalonej od miasta części Lasu Wiedeńskiego, położonego nawet fragmentarycznie w granicach administracyjnych stolicy Austrii, staje się okazją do wykpienia przyzwyczajeń, gustów, ciasnoty zainteresowań i stereotypów kulturalnych, do których obezwładniający strach przed kleszczami, znany w ostatnich dekadach dobrze i Polakom, pasuje jak ulał. W utworze z innej epoki, należącym do innej literatury, to jest w Lecie leśnych ludzi Marii Rodziewiczówny (1920), czytamy o przybyciu do mieszkającego w leśnej głuszy wuja miejskiego młodzieńca, który w swojej naiwności popełnia wiele gaf, nie umiejąc się poruszać po nowym terenie, nie potrafiąc rozpoznawać odgłosów zwierząt i ciągle pytając strachliwie: „co to?” (dlatego dostaje od leśnych ludzi przydomek Coto). Z jednego z przykładów qui pro quo dowiadujemy się, że bierze on robaczki świętojańskie za wilcze oczy, co być może odczuwamy już jako nazbyt przerysowaną karykaturę ${ }^{20}$. Jednocześnie jednak z rozmowy Cota z wujem dowiadujemy się, że dwudziestolatek w mieście zbierał „owady, marki pocztowe, monety”21. Być może, abstrahując od siły bezwładu podobnej figury przestraszonego mieszczucha, mówi nam ona również coś o separacji światów sztucznej kolekcji i żywych istot w leśnym biotopie, rozejściu się porządku estetycznego i ekologicznego w „nienaturalnej” przestrzeni miasta z przełomu wieków XIX i XX (pamiętać należy przy tym, że owady stały się jednym z głównych motywów dekoracyjnych secesji). Rodzą się przy tej okazji dodatkowe pytania: jakie owady mógł zbierać Coto oraz jak ma się opisywana przez Rodziewiczównę praktyka wypychania zwierząt, której poświęcają dużo czasu leśni ludzie, do wychwalanego życia w zgodzie z przyrodą?

Akcja opowieści z owadami jako ważnymi bohaterami toczy się zwykle na wsi, w lesie, na łące; miasto jest położone - jeśli w ogóle się o nim wspomina - w oddali. Trzeba je nawet porzucić, żeby zająć się entomofauną czy w ogóle się z nią spotkać. Doktor Muchołapski Erazma Majewskiego (1890) zaczyna się wprawdzie w kamienicy przy ulicy Miodowej w Warszawie, ważna dla losów tytułowego bohatera będzie wizyta w Łazienkach (pamiętajmy jednak, że ten park właściwie leżał wówczas na peryferiach miasta, tuż obok jego administracyjnej i rzeczywistej granicy), gdzie zajęty polowaniem na rzadki gatunek łowika zapomni o swoim ślubie, lecz prawdziwe mikroprzygody przeżywa się pod Tatrami22. Niewątpliwie poza miastem fauna bezkręgowców jest bogatsza, nieodkryta, można ją w większym spokoju obserwować - zdają nam się mówić losy również rzeczywistych badaczy, herosów dziewiętnastowiecznej entomologii, z kwaterującym w niedużej prowansalskiej miejscowości Jeanem-Henrim Fabre’em na czele. Do miasta jednak badacze stawonogów wrócą, i to nie tylko jako parazytolodzy. Już w 1922 roku Stanisław Sumiński pisał: „Aby dać pojęcie o liczebności owadów w Warszawie, wystarczy powiedzieć, że samych chrząszczy żyje w niej około 1000 gatunków”23, po czym spróbował wskazać te miejsca, gdzie warszawiacy mogli spotkać się częściej z konkretnymi rzędami, nie ograniczając się do mieszkań i przydomowych ogródków. Jednocześnie ten sam autor wraz z Szymonem Tenenbaumem wydał rok wcześniej Przewodnik zoologiczny po okolicach Warszawy, gdzie przystępnie omówił najważniejsze stanowiska faunistyczne w mieście i wokół niego, nie szczędząc czytelnikom owadów ${ }^{24}$. Analogii w obrazach i narracjach literackich próżno jednak szukać. Bardziej anegdotyczne i bardziej dokuczliwe są pasożyty. Symptomatyczne jest być może spojrzenie Ireny Krzywickiej, która w swoim eseju tylko pluskwy uczyniła godnymi stanięcia w szeregu z psami, kotami, końmi, wiewiórkami, gołębiami, wróblami i rybkami akwariowymi ${ }^{25}$. W jakiejś mierze powtarzający się u obojga przywołanych autorów - entomologa i publicystki - tytuł Fauna Warszawy dobrze oddaje skrajną przeciwstawność spojrzenia: specjalisty i mieszkanki miasta.

Jeśli pisarz wprowadza owady w większej liczbie do przestrzeni miasta, to zazwyczaj jest to sygnałem jakiegoś naddatku, zresztą zwykle nawiązującym do repertuaru znanych i ugruntowanych skojarzeń i symboli. W rozgrywającym się w Warszawie Wniebowstąpieniu Tadeusza Konwickiego (1967) mamy do czynienia z powracającym motywem spotykanych owadów - już w ekspozycji, gdy anonimowy bohater-narrator budzi się, leżąc w parku pod wiaduktem z twarzą przykrytą gazetą, i widzi wspinającą się po zadrukowanym papierze „bożą krówkę”26. Przemysław 
Kaniecki wpisywał tę biedronkę w szereg występujących w pisarstwie Konwickiego przedstawicielek coccinellidae, które wcześniej w Dziurze w niebie, Senniku współczesnym, a później w Nic albo nic, Kronice wypadków miłosnych, Małej Apokalipsie i Bohini ukazują się postaciom będącym u kresu życia. „Boży» owad we wszystkich wspomnianych scenach podkreśla bliskość śmierci - pisze Kaniecki - ale też w wielu wypadkach jakoś bohaterów pokrzepia, pomaga im stawić czoła trudnej rzeczywistości, pomaga na chwilę ją «obłaskawić», choćby emocjonalnie"27. Badacz wskazuje na kołatka i/lub kornika, które przejmują tę symboliczną rolę towarzysza okoliczności liminalnych w innych powieściach pisarza ${ }^{28}$. W świecie przedstawionym Wniebowstąpienia, czego Kaniecki nie zauważa, a w każdym razie szerzej nie analizuje, ta inicjalna biedronka uruchamia ciąg owadów i pajęczaków nawiązujących do topiki oraz symboliki wanitatywnej. Przede wszystkim już we wstępnej rozmowie z Lilkiem, informującym bohatera o sytuacji sprzed jego ocknięcia się pod wiaduktem, dowiadujemy się, że ten leżał tak, jakby był już martwy, ponieważ obsiadły go muchy. Do jego policzka przyczepia się również „długie pasmo babiego lata” (s. 7). Świadomość narratora w trakcie kilkunastu godzin akcji zarejestruje „chudego pająka z cienkimi jak włosy nogami” wspinającego się daremnie po szybie taksówki (s. 49), czerwoną mrówkę idącą w poprzek okienka w trumnie ze zmarłym Amerykaninem (s. 102), śpiące - czy też raczej umarłe - żółte motyle za szybą, w każdym razie „zastygłe o milimetr od wolności” (s. 114), w miejscu czuwania przy trumnie znajduje się „naderwana w kilku miejscach pajęczyna zgrubiała od kurzu” i „płomyki świec jak ogromne białe ćmy” (s. 115). Z kolei do czarnych motyli zostaną porównane liście lecące z drzew obok Cytadeli w trakcie autobusowej podróży z Bródna do Bristolu (s. 126), gdzie w barze narrator zauważa wspinającego się po butelce ajerkoniaku jakiegoś owada, żuczka czy muszkę - na początku nie jest pewien, okazuje się nim jednak „domowa pluskwa zagubiona wśród kosztownych alkoholi wytwornej knajpy nocnej” (s. 129). Potem następują dwie pajęcze figury - pierwsza w porównaniu ludzkiego życia do „cienkiego jak pajęczyna” „pasemka rozpiętego na niewielkim kartoflu planety” (s. 150), druga w uogólnionym opisie nieba, po którym „pędzą ciągle te same obłoki gubiące białe nitki babiego lata” (s. 170). Dopełnia je kolejny pajęczy produkt, czyli po raz kolejny „długie i splątane nici babiego lata”, które po pożegnaniu z robotnikami rozładowującymi mięso uczepiają się dłoni bohatera (s. 172). Wreszcie owady towarzyszą finalnej scenie w Pałacu Kultury - w skromnym bufecie znajdującym się w jego holu drzemią sobie muchy na kanapkach z serem (s. 182), a na tarasie widokowym pośród wszystkich znanych nam już osób narrator widzi Niemca, który „oglądał mrówkę biegnącą po jego dłoni, mrówkę na trzydziestym trzecim piętrze pałacu” (s. 187) na tyle uważnie, że nie odpowiada na pytanie, „zapatrzony w żyjątko, które wspinało się na pagór nasady kciuka i stale osuwało w dolinę dłoni” (s. 188).

Mamy więc przegląd owadów symbolizujących nietrwałość, przemijanie, rozkład, jak również bezcelowość działań i marność wysiłku. Trudno skonstatować połowicznie nawet konsolacyjny charakter spotkań z tymi zwierzętami, nie dodają one w żadnej mierze bohaterowi otuchy, raczej odwrotnie (niektóre z nich są w dodatku martwe). Współtworzą krąg czyśćcowo-apokaliptycznych skojarzeń i metafor, którymi przesycony jest świat przedstawiony Wniebowstąpienia ${ }^{29}$. Mimo problemów z określeniem pory roku, w której toczy się akcja powieści, najwięcej symptomów sprzyja identyfikacji jej z szeroko pojętym schyłkiem lata/wczesną jesienią (miasto szykuje się do dożynek, które mają odbyć się następnego dnia) - sygnały ze świata bezkręgowców zdają się je popierać, zwłaszcza klamra lecących nici babiego lata na początku i pod koniec tej historii. Babie lato to okres wyłączenia, swoistej dylatacji, pozwalającej na spowolnienie czy chwilowe zawieszenie czasu, nie tyle umożliwiające spojrzenie z boku czy z dystansu na rzeczywistość, ile raczej dające możliwość jej przybliżenia, powiększenia, studiowania. Ta szczególna cecha tej pory roku była zresztą w ówczesnej literaturze przedmiotem przynajmniej jednego znanego utworu prozatorskiego, to jest opowiadania Julia Cortázara z 1959 roku właśnie pod tytułem Babie lato. Niedzielna wizyta fotografa na odludnym placyku Wyspy św. Ludwika w Paryżu owocuje minifotoreportażem, którego tematem jest spotkanie miłosne młodego mężczyzny ze starszą od niego kobietą. Dopiero po jakimś czasie, w trakcie wywoływania zdjęć, ich autor orientuje się, jaki był właściwy charakter zdarzenia - niech nie umknie naszej uwadze fakt, że hiszpańskie określenie na tę porę i zjawisko, więc także oryginalny tytuł tego opowiadania, Las babas del diablo, brzmi dosłownie „diabelska ślina”30. Manifestem nieoczywistego realizmu był także znany obraz Józefa Chełmońskiego pod takim samym tytułem, który pomawiano nie tylko 
o antyestetyzm, lecz także o niedbalstwo techniczne ${ }^{31}$. Bardzo wiele elementów dotyczących czasu i miejsca w powieści Konwickiego jest celowo przez autora mistyfikowanych, by wytworzyć aurę fantastyczności, pewnego odrealnienia, nocy żywych trupów, ustanowić parabolę. Są to środki pozwalające na powiększenie zniekształcające, ale określone sprawy można dzięki niemu zobaczyć lepiej. Wobec takiej postawy autorskiej szczegóły techniczne mają mniejsze znaczenie albo inaczej: odnoszą się do innego rodzaju prozy, w której ważne jest to, by poszczególne wydarzenia mieściły się pod kątem czasoprzestrzennej zgodności w kolejnych partiach powieści. Powtarzana anegdota mówi, że Cortázar odwiedził Warszawę z francuskim wydaniem Wniebowstąpienia jako przewodnikiem po mieście pod pachą ${ }^{32}$, nie wiemy jednak, czy dobrze mu się ją zwiedzało i czy znalazł, czego szukał.

Należy wziąć pod uwagę jeszcze jeden trop tyleż miejski, ile właśnie owadzi, który nie unieważnia tego, co poprzednio napisałem. Znana figura ludzkiej społeczności jako mrowiska czy też po prostu owadziego mikrokosmosu przyjmuje tutaj - na poły realne - kształty Warszawy z czasów schyłku małej stabilizacji. Miasta wciąż jeszcze zrujnowanego i niepozbawionego drewnianej zabudowy, zawieszonego pomiędzy duchami przeszłości a współczesnymi marzeniami i snami o przyszłości, miasta kontrastów, z częściowo zapomnianymi, a częściowo zmitologizowanymi tradycjami, ale z wielkomiejskimi aspiracjami, miasta napięć, których symbolem jest powracający w powieści Pałac Kultury i Nauki ${ }^{33}$. „Mrowiu ludzi” zebranemu na placu pod tym gmachem w jednej z pierwszych scen powieści (s. 26) odpowiada ludzka dłoń, którą próbuje sforsować mrówka w ostatniej scenie rozgrywającej się na jego tarasie, gdy bohaterowie próbują na próżno zjechać na dół budowli (s. 188). Wspinające się bezskutecznie po szklanych powierzchniach lub próbujące się przez nie dostać: pająk, ćmy, pluskwa przywołują również metaforykę szkła z całą jej złożonością, szkła, które jest przecież materiałem dla myślenia o nowoczesnej metropolii konstytutywnym. Zostaje wreszcie uruchomiona perspektywa kosmiczna, o której wspomina Bernard w trakcie powrotu z Bródna („Nie tylko makrokosmos jest nieskończony. Mikrokosmos również. Ty mnie rozumiesz? Konkurencyjna nieskończoność” [s. 125]), choć wcześniej zostaje ona zasugerowana w różny sposób, może najsubtelniej w momencie, gdy główny bohater wybiega z domu czuwania i widzi między innymi „glinianki pełne drobin gwiazdozbiorów" (s. 116). Z pozoru wprowadzając temat natury (obecny również w powieści w formie lęków ekologicznych w monologach wewnętrznych narratora, próbującego zrekonstruować swój świat i swoją tożsamość), traci on sprzed oczu konkretne miasto, ale może warto pomyśleć o naturze jako o czymś, co dotyczy także Warszawy jako określonego ekosystemu. Nie tylko dlatego, że wszystkie te rozważania dzieją się w tym właśnie mieście, a glinianki to produkt określonej gospodarki miejskiej. Gwiazdozbiory rozumieć można intuicyjnie jako odbite w wodzie gwiazdy, po chwili wahania jako żyjący w niej świat drobnoustrojów, ale czemu nie światła i neony wielkiego miasta, które wciąż fiksują uwagę narratora przemierzającego nocną stolicę? O wielkiej przenośni egzystencjalnej dla tego obrazu wspominać nie potrzeba. Dodajmy także, że temat nieograniczonej rozciągłości wraca w finale na trzydziestym trzecim piętrze. „Tak wygląda początek nieskończoności” - mówi Bernard do narratora, a my nie możemy być pewni, czy chodzi tu tylko o przełamanie czasowości, czy także o przestrzeń. Warszawa jako miasto jest nieskończona w każdym możliwym sensie. Popularną komediową analogią do tych obrazów z Pałacem Kultury w roli głównej jest finał filmu znacznie późniejszego, bo nakręconego u kresu Polski Ludowej, to jest Kingsajzu Juliusza Machulskiego, podobnie operującego skalą mikro dla dopełnienia porównania. W tym przypadku dopełnieniem świata ludzkiego był świat krasnoludków, a bohaterowie znajdowali się w ostatniej scenie w modelu kolejki elektrycznej kręcącej się w kółko na trawniku przed Pałacem, której operatorem było dziecko.

Miasto owadów to temat, który wytwarza bardzo różne narracje i spojrzenia. Wniebowstąpienie Konwickiego należy do tego nurtu, który podnosi epizodyczność jako główną cechę potocznego doświadczania tych zwierząt, ale poprzez zwrócenie na nie uwagi, kolekcjonowanie przypadków jest w tych opowieściach wpisana deformacja świata. Nie zawsze tak jest. Taka deformacja może być naturalizowana w zależności od konwencji, na przykład w Pchle Szachrajce Jana Brzechwy (1946), która jest bajką dla dzieci, mieszkają w Warszawie tylko ludzie i zantropomorfizowane owady. Z kolei w wierszu Piosenka przeciw szarańczy Marcina Świetlickiego (2015) zapewne nie wzbudza niepokoju zestawienie „dziwnego ludu” wybierającego prezydenta miasta (w domyśle: Krakowa) na kolejną kadencję ze zjawiskami naturalnymi: zmierzchem i tytułową 
szarańczą ${ }^{34}$. Jest to temat do głębszego namysłu, który potrzebowałby z pewnością także obfitszego materiału badawczego. Niewątpliwie nie mówią owe narracje jednak niczego - albo bardzo mało - o rzeczywistych owadach żyjących w mieście czy o wpływie środowiska miejskiego na ekologię i ewolucję tych zwierząt. Najbardziej znanym, „podręcznikowym” przypadkiem tych procesów jest krępak nabrzozak, ćma, która zmieniła dwukrotnie barwę skrzydeł - z jasnej na ciemną, wtedy gdy wraz z zanieczyszczeniem wielkiego przemysłu sadze ściemniły korę drzew, oraz z powrotem, gdy w epoce postindustrialnej zaczęło być w miastach czyściej i znowu opłaciło się mieć jasne skrzydła ${ }^{35}$. W przykładach narracji, zapisów, które przywołałem, owady się ludziom przytrafiają. To przyzwyczajenie, z którym niełatwo polemizować, i dlatego siłą takich publikacji, jak świeżo wydana po polsku książka amerykańskiego biologa Roba Dunna Nie jesteś sam $w$ domu, jest próba przekonującego i popularnego opowiedzenia, że one się nie przytrafiają, tylko są. Nawet jeśli są niewidoczne czy niezauważalne. To gest podobny do tego, jaki robią badacze lub obserwatorki codzienności: uczynienie z przezroczystego nieprzezroczystego. Elżbieta Kozłowska w Przyrodzie miasta, książce dla młodego czytelnika wydanej w roku 1988, w niefortunnym dla wszelkich interesujących przedsięwzięć edytorskich okresie ${ }^{36}$, próbowała również wykonać taki właśnie gest, przywracając właściwe proporcje udziału w naszym wspólnym świecie bezkręgowcom ${ }^{37}$.

Chciałbym wrócić jeszcze do zdania Pereca o osach „zaraz po wojnie”. Wojna jako stan nienormalny nie pozostaje bez wpływu na miejski ekosystem. Różne zarządzenia władz okupacyjnych, specjalny tryb pracy, zmiany w gospodarce, przekształcenia zieleni, duża mobilność ludzi, nie mówiąc już o zniszczeniach, mają przełożenie na fluktuację entomofauny (a w przypadku II wojny światowej dodać należy ciąg bardzo ostrych zim na początku lat 40. opóźniających wegetację). Jeśli chodzi o Warszawę, to Stanisław Adamczewski w napisanym w grudniu 1945 roku artykule wymieniał charakterystyczne zdarzenia wojenne w świecie owadów i ich przyczyny: z powodu wczesnej godziny policyjnej rozmnożenie się ciem, których gąsienice żerują na drzewach rosnących w mieście; zasadnicze zubożenie fauny ciem z uwagi na zaciemnienie; wielkie wyrajania się chrząszczy w niesterylnie przechowywanych sucharach; zwiększenie się populacji komara z uwagi na budowę przez Niemców w Śródmieściu licznych betonowych zbiorników na wodę. Konsekwencją hekatomby z 1944 roku było pojawienie się nekrofauny: chrząszczy grabarzy oraz licznych, niewidywanych od dawna w Warszawie much. Stan po zniszczeniach wojennych sprzyjał pojawieniu się roślin ruderalnych, na polach wokół miasta Adamczewski stwierdzał stepowienie łąk, co pociągnęło za sobą obfitość koników polnych opanowujących ruiny i przedpola stolicy (na ugorach koło Łomianek oraz w okolicach Sulejówka notowano w tymże roku nawet osobniki szarańczy) ${ }^{38}$. W związku z odbudową większość tych zmian szybciej lub wolniej zniknęła, chociaż, sądząc zarówno z informacji prasowych, jak i publikacji naukowych, problem z nadmiarem much stał się głównym higienicznym wyzwaniem polskiej codzienności lat 40. i 5039. Wojna jako stan nadzwyczajny, oddziałujący także po ustaniu działań zbrojnych, powoduje wyostrzenie i poszerzenie pola widzenia człowieka, dzięki któremu owady mogą być zauważone, a jednocześnie potwierdza się ich marginalność w czasie zwyczajnym. „Rzadko nachodzą mnie myśli o nieskończenie małym, o nosie Kleopatry, o dziurach w serze gruyère lub o nietzscheańskich inspiracjach Maurice’a Leblanca czy Joego Shustera” - pisał Perec w jednym z esejów ${ }^{40}$. Owady pojawiają się w jego twórczości epizodycznie, spotkamy je w parodii tekstu naukowego, wypisanym cytacie ze Swifta, w drugorzędnych porównaniach, w daremnej wędrówce muchy obserwowanej przez człowieka, który śpi ${ }^{41}$.

Zdanie o osach zaraz po wojnie nabrało jeszcze jednego wymiaru ostatnio, tym bardziej wymownego w kontekście perekowskim. Perec był bowiem praktykiem i teoretykiem lipogramu, a więc gatunku, którego istotą jest pozbawienie wypowiedzi danej litery (względnie liter). Mniej lub bardziej zauważalne zniknięcie elementu konstytuuje świat, który jest zasadniczo inny, ułomny, choć niektórym z nas trudniej przychodzi dostrzeżenie tego faktu. Zdaje się, że nie może być lepszej metafory dla mniej lub bardziej uważnie obserwowanego wymierania owadów, z którym mamy do czynienia w ostatnich latach czy dekadach. Lipogram to forma, która godzi epizodyczność i anegdotyczność narracji o owadach z encyklopedyzmem oraz kolekcjonerstwem, pretensjami do całościowości. Wszystkie one dotyczą bezpowrotnie (?) minionej przeszłości. 


\section{PRZYPISY}

1 I. Newerly, Pamiątka z Celulozy, Warszawa 1988, s. 148.

2 Tamże, s. 150-151.

3 Tamże, s. 150

4. Tamże, s. 152

5 I.H., Warszawa egzotyczna. Wśród Chińczyków, „Kurier Warszawski” 1939, nr 159, s. 17

6 Samborska jest modelowym warszawskim zaułkiem również dlatego, że została ona w miejscu swojego dawnego istnienia przywrócona po latach do życia. Zniszczona w czasie wojny, w pewnym momencie zniknęła z planów Warszawy, chociaż wróciła i przez około trzydzieści lat po wojnie nazwa ta odnosiła się do jeszcze zupełnie innej uliczki, jeśli można użyć takiego słowa, a mianowicie położonego w bliskiej okolicy dawnej Samborskiej początkowego, patrząc od skarpy, fragmentu Wójtowskiej i/lub schodów prowadzących do zbiegu Rybaków i Sanguszki, odpowiadających mniej więcej przedwojennej Zakątnej. W 2010 roku niedostepna dotąd ślepa zatoczka ulicy Przyrynek została z inicjatywy ówczesnego burmistrza Śródmieścia Wojciecha Bartelskiego wyremontowana, ma mieć obecnie 22 metry i uchodzi za najkrótszą ulicę w Polsce. Znajduje się dokładnie w miejscu dawnej Samborskiej, chociaż jest krótsza, a i zabudowa nie ma nic wspólnego z opisywaną przez Newerlego. Otwarciu zaułka towarzyszyły wydarzenia, happeningi, próby wpisania w nią różnych tradycji wynalezionych czy po prostu fikcjonalizacji (np. przywoływany przez "Życie Warszawy" przewodnik opowiadający o Chopinie, który miał wymyślić Walca minutowego, spacerując po Samborskiej!) - w każdym razie karaluchy Newerlego nie zostały zainscenizowane. A. Sabała, Małe jest piękne, czyli najmniejsza ulica otwarta, http://www.zw.com.pl/artykul/469308_Male_jest_piekne__czyli_najmniejsza_ulica_otwarta.html (dostęp: 26.02.2020).

7 Warszawa zapamiętana. Dwudziestolecie międzywojenne, oprac. M. Szymańska, Warszawa 2018, s. 56-58.

8 J. Zieliński, Szkatułki Newerlego, Warszawa 2012, s. 279-281.

9 A. Wat, Mój wiek. Pamiętnik mówiony, cz. 2, rozmowy przeprowadził i przedmową opatrzył C. Miłosz, przygotowała do druku L. Ciołkoszowa, Warszawa 1998, s. 201-203.

10 W. Gomulicki, Zaułek, w: tenże, Warszawa wczorajsza, tekst zebrał i oprac. J.W. Gomulicki, Warszawa 1961, s. 44.

11 M. Żółkoś, Mikro-formy i makro-lęki. Owady jako wyzwanie dla animal studies, w: A. Barcz, D. Łagodzka (red.), Zwierzęta i ich ludzie. Zmierzch antropocentrycznego paradygmatu, Warszawa 2015, s. 36-39.

12 G. Perec, Pamiętam że, przeł. K. Zabłocki, Kraków 2013, s. 35

13 as, Komary w Warszawie. Do tramwaju wdarły się setki komarów. „Pasażerowie próbowali w panice uciekać”, https://metrowarszawa.gazeta.pl/metrowarszawa/7,141637,24894464,komary-w-warszawie-do-tramwaju-wdarly-sie-setki-komarow-pasazerowie.html (dostęp: 16.03.2020).

14 M. Wojtczuk, M. Śmigiel, Plaga komarów w Warszawie. Oprysków nie będzie, https://warszawa.wyborcza.pl/warszawa/7,54420,24901304,plaga-komarow-w-warszawie-opryskow-nie-bedzie.html (dostęp: 16.03.2020)

15 M. Żółkoś, Teatr owadów, „Didaskalia” 2019, nr 153, s. 77-79.

16 Ogłoszenie prasowe z "Gazety Toruńskiej” z 5 lipca 1877 roku za: D. Meller, Ponad sto lat temu równie atrakcyjne, co przedstawienia cyrkowe, były prasowe ogłoszenia zapraszajace na te występy, https://plus. nowosci.com.pl/ponad-sto-lat-temu-rownie-atrakcyjne-co-przedstawienia-cyrkowe-byly-prasowe-ogloszenia-zapraszajace-na-te-wystepy-album-rodzinny/ar/13355568 (dostęp: 27.03.2020).

17 Musiałoby to dotyczyć drugiej połowy XIX wieku (autor nie precyzuje danych dotyczących rękopiśmiennej relacji Justa). A. Łupienko, Kamienice czynszowe Warszawy 1864-1914, Warszawa 2015, s. 198.

18 Szerzej pisze o tym Monika Żółkoś w cytowanym artykule: M. Żółkoś, Teatr owadów, dz. cyt.

19 T. Bernhard, Claus Peymann i Hermann Beil na Sulzwiese, w: tegoż, Claus Peymann kupuje sobie spodnie i idzie ze mna na obiad. Trzy dramoletki, przeł. S. Lisiecka, Łódź 2019, s. 66.

20 M. Rodziewiczówna, Lato leśnych ludzi, Warszawa-Kraków-Łódź-Poznań 1921, s. 78-79.

21 Tamże, s. 88.

22 E. Majewski, Doktor Muchołapski. Fantastyczne przygody w świecie owadów, Warszawa 2013.

23 S. Sumiński, Fauna Warszawy, "Ziemia” 1922, nr 12, s. 333-334.

24 S. Sumiński, S. Tenenbaum, Przewodnik zoologiczny po okolicach Warszawy, Warszawa 1921.

25 I. Krzywicka, Fauna Warszawy, „Wiadomości Literackie” 1938, nr 52-53, s. 30.

26 T. Konwicki, Wniebowstapienie, Warszawa 1990, s. 5; następne cytaty według tego wydania

27 P. Kaniecki, Wniebowstapienia Konwickiego, Warszawa 2013, s. 168.

28 Tamże, przyp. 1

29 Tamże, s. 195-200, 205-207 
30 J. Cortázar, Babie lato, przeł. Z. Chądzyńska, w: tegoż, Opowiadania, przeł. Z. Chądzyńska, M. Jordan, t. 1, Warszawa 2009

31 K. Czarnocka, Chełmoński, Warszawa 1957, s. 36-41.

32 T. Konwicki, W pośpiechu rozmawia z Przemysławem Kanieckim, Wołowiec 2011, s. 68-69.

33 Tenże, W pośpiechu..., dz. cyt., s. 135; K. Niciński, „Wniebowstapienie”. Próba lektury topograficznej, w: A. Karpowicz i in. (red.), „Ułamek błękitu i chmur”. Warszawa Tadeusza Konwickiego, Warszawa 2017, s. $156-181$.

34 M. Świetlicki, Piosenka przeciw szarańczy, w: tenże, Delta Dietla. Wiersze z lat 2013-2015, Kraków 2015, s. 82.

35 M. Schilthuizen, Ewolucja w miejskiej dżungli. Jak zwierzęta i rośliny dostosowują się do życia wśród nas przeł. J. Wołk-Łaniewski, Łódź 2019, rozdz. 8: Legendy miejskie, s. 117-133. Autor omawia jeszcze kilka owadzich przypadków (m.in. komarów żyjących w londyńskim metrze; tamże s. 11-15). Cała książka oparta jest na wyjściowej analogii „inżynierów ekosystemu”: ludzie-miasta/mrowiska-mrówki (tamże, s. 32).

36 Z. Beszczyńska, Człowiek rujnuje, natura buduje, "Guliwer" 1995, nr 1, s. 40.

37 E. Kozłowska, Przyroda miasta, il. M. Mackiewicz, Warszawa 1988.

38 S. Adamczewski, Rzut oka na zmiany w faunie Warszawy i okolic wywołane przez wojnę, "Polskie Pismo Entomologiczne" 1939-1948, t. 18, z. 1-4, s. 268-275.

39 Np. (P-k), Zaniedbane śmietniki warszawskie wylęgarnia much, "Express Wieczorny" 1951, nr 197, s. 5 (Wś), Zaczyna się plaga much!, "Express Wieczorny” 1953, nr 142, s. 3; A. Jeziorańska, Rozmieszczenie muchy domowej na terenie Warszawy w 1949-1950 r., "Acta Parasitologica Polonica” 1954, t. 2, fasc. 1.

40 G. Perec, Myśleć/Klasyfikować, przeł. A. Rębkowska, w: tenże, Urodziłem się. Eseje, red. J. Olczyk, Kraków 2012, s. 101.

41 Tenże, Dyslokacja czasoprzestrzenna Coscinoscera Vitoria, Coscinoscera tigrata carpenteri, Coscinoscera punctata Barton i Coscinoscera nigrostriata z Iputupi, przeł. J. Gondowicz, w: tenże, Urodziłem się..., dz. cyt.; tenże, Przestrzenie, przeł. A. Daniłowicz-Grudzińska, Kraków 2019, s. 161; tenże, Człowiek, który śpi, przeł. A. Wasilewska, Kraków 2011, s. 18, 97 
Karolina Wróbel-Bardzik

\section{„Była to śmierć olbrzymia i liczna". Zwierzęta oraz bombardowanie Warszawy w czasie kampanii wrześniowej 1939 roku $^{1}$}

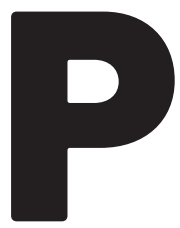

ierwsze bombardowania Warszawy zaczęły się już w dniu agresji Niemiec na Polskę 1 września 1939 roku i trwały niemal miesiąc, do ogłoszenia kapitulacji miasta. Kampania wrześniowa była wstępną fazą, niejako preludium zmasowanych nalotów powietrznych w czasie II wojny światowej ${ }^{2}$, ale już wówczas ze względu na skalę było to zdarzenie bez precedensu - „bombardowanie jest szczytowym momentem wojny totalnej”, które umożliwia „dostęp do technologii militarnej służącej masowemu zniszczeniu”. Śmierć ponosiła ludność cywilna, za cel obrano kościoły, szpitale i inne budynki użyteczności publicznej, co było jednoznacznym złamaniem przez Niemców art. 27 konwencji haskiej z 1907 roku, która tego zakazywała ${ }^{4}$. Jacek Leociak, pisząc o zjawisku i historii bombardowań, wskazuje, że należą one do doświadczeń granicznych, a ich efektem jest „makabryczna przemiana” miasta, gdy „W dziele zniszczenia uczestniczą [...] dwie siły: eksplozja i ogień”. Zdają się to potwierdzać opisy już z pierwszych dni kampanii. W relacji anonimowej kobiety z 2 września czytamy: „Część cmentarza [Powązkowskiego - K.W.B.] przedstawia makabryczny widok, nasuwając swym wyglądem na kliszę wyobraźni piekło Dantego, z jego okropnościami”. Halina Regulska w Dzienniku z oblężonej Warszawy odnotowała natomiast: „Ludzie opowiadają, że na szosach dzieją się dantejskie sceny [...]. Samoloty pochylają się ku ziemi, pikują z wyciem i rzucają bomby w tłum strzelając gęsto $\mathrm{z}$ broni pokładowej””.

Bilans strat z jednego dnia przedstawiał się następująco: naloty z 13 września wywołały na przykład 270 pożarów w centrum oraz w północnej części miasta, oficjalnie życie straciło 150 osób $^{8}$. Najintensywniejsze ostrzeliwania miasta nadeszły jednak 25 września - dzień ten, zapamiętany jako najcięższy w czasie całej kampanii, nazwany został „krwawym poniedziałkiem”. Miasto bombardowało bez ustanku 400 samolotów niemieckich: 100 Dornierów, 240 bombowców nurkujących i 30 ciężkich transportowych Junkersów oraz bombowce Heinkle. Zrzucono 560 ton bomb burzących oraz 72 tony bomb zapalających ${ }^{9}$. Był to „zmasowany, całodzienny atak z ziemi i z powietrza na Warszawę - wówczas największy w historii atak bombowy na miasto"10.

Po bombardowaniach miejskie krajobrazy zamieniały się w ruiny, pod gruzami ginęli nie tylko ludzie, lecz także zwierzęta, rzadko ujmowane jednak w statystykach. Ich śmierć nadal pozostaje tematem sytuującym się na obrzeżach dyskursu o działaniach wojennych. Bogata literatura na temat II wojny światowej w niedostatecznym stopniu poświęca im uwagę, dlatego należy skoncentrować się na tym, co zjawia się w polu widzenia okupowanego miasta - jest to między 
innymi los koni i zwierząt z ogrodów zoologicznych, co nie wyczerpuje oczywiście wszystkich kontekstów relacji ludzko-zwierzęcych w mieście ogarniętym wojną, ale pozwala dostrzec pewne kluczowe zależności. Warto przywołać wykłady zuryskie W.G. Sebalda zebrane w tomie Wojna powietrzna i literatura, w których pojawiają się wątki botaniczne i zoologiczne. Zdaje się on sugerować równorzędność śmierci podmiotów ludzkich i pozaludzkich podczas drugowojennych nalotów powietrznych w Niemczech, gdy dokonywała się „w ciągu kilku godzin śmierć całego miasta w płomieniach, z budynkami i drzewami, z mieszkańcami, zwierzętami domowymi, sprzętami i wszelkimi urządzeniami [...]"11. Podobne aspekty w odniesieniu do Warszawy podjęte zostały w Mieście niepokonanym Kazimierza Brandysa, gdzie opisana została stolica, w której wyniszczenie dotyczyło ludzi, zwierząt, roślin i infrastruktury: „Była to śmierć olbrzymia i liczna. Ginęły mury i ludzie, sprzęty, drzewa i latarnie, parkany, klomby, konie, tramwaje"12.

W czasie historycznych konfliktów zbrojnych szczególnie dużo trupów zwierzęcych znajdowało się wśród koni, dlatego często „postrzega się je jako symbol wojny” ${ }^{13}$. Èric Baratay, historyk zwierząt, stwierdza, że tego typu obrazy koni nie są jedynie kulturowymi konstruktami, i podkreśla materialność ich śmierci:

[...] Jest to także rzeczywistość wojny, która naznaczona została wszechobecnością koniowatych, ich wysoką śmiertelnością, obecnością trupów, niezbieranych, niegrzebanych, niczym nieprzykrywanych, lecz zostawianych na miejscu, choćby na środku drogi, przez co oddziały zmuszone są potykać się o nie, patrzeć na „trupie wydzieliny”, wdychać „zalewający odór”, „straszny smród”"14.

Należy odnotować, że w chwili wybuchu wojny w samej Warszawie znajdowało się ponad 8000 koni, z czego większość z nich zginęła ${ }^{15}$. Tak duża ich liczba w przedwojennym mieście może pozornie zaskakiwać, zważywszy na postępującą mechanizację transportu w dwudziestoleciu międzywojennym, upowszechnienie się tramwajów elektrycznych, a także taksówek samochodowych. Czynniki te nie przyczyniły się jednak do całkowitego wycofania koni z Warszawy, które wciąż pracowały przy dorożkach, dominowały ponadto w transporcie towarów ${ }^{16}$. Wojenna literatura wspomnieniowa zaświadcza niejako o śmierci koni, możemy dowiedzieć się z niej, że po wrześniowych bombardowaniach ulice zasłały się trupami zarówno ludzi, jak i koni. Zdzisław Żórawski, autor Dziennika obrońcy Warszawy, zanotował 19 września, że na ulicach miasta było dużo martwych zwierząt, ciała których służby porządkowe wówczas jeszcze sprawnie usuwały:

Mimo zniszczeń i strat spowodowanych bombardowaniem Warszawa jest utrzymywana we wzorowej czystości. Z nadejściem nocy wychodzą specjalne drużyny sprzątających, które usuwają z ulic trupy końskie i gruzy domów, oczyszczają jezdnie ze śladów walki. Ranek zastaje Warszawę znów czystą i świeżą ${ }^{17}$.

Natomiast w dniach późniejszych - wraz z nasileniem ataków powietrznych - wzrosła także śmiertelność: „Trupów końskich, których zawsze w ciągu dnia jest dość dużo na ulicach, służba miejska już nie nadąża uprzątać"18. W monumentalnej Kronicelat wojnyiokupacji Ludwika Landaua czytamy, że 27 września „ulice - pełne gruzu, potłuczonego szkła, trupów ludzkich i końskich, pod zwieszającymi się zerwanymi drutami elektrycznych przewodów tramwajowych zaroiły się od ludzi [...]"19. Żórawski zauważał, że wobec doskwierającego głodu ludzie zaczęli wyręczać służby porządkowe i ciąć martwe konie, porcjując je na mięso ${ }^{20}$. Jeden z mieszkańców Mokotowa tak to opisywał: „Dobrze się nam zaczęło powodzić pod względem aprowizacji: żona moja z nożem w ręku i koszykiem biegła rano, jakby na targ, na parcelę sąsiednią, na której leżały trupy koni, zabitych bombami w nocy”. I dalej dodaje: „- Głupi właściciel - śmiały się sąsiadkizamiast konie uchronić przed okiem lotnika w stajni wypuścił je na pastwisko, gdzie zamknięte ogrodzeniem tak długo galopowały w kółko, rżąc ze strachu, aż zobaczył je z góry niemiecki lotnik. Wkrótce boki końskich trupów były obnażone aż do żeber"21.

W owym czasie w mieście pootwierane zostały jatki z koniną. Na rzeź poszły także konie artyleryjskie - „zbyteczne już wobec ustawień baterii na stałych stanowiskach”22. Działania 
wojenne we wrześniu przyniosły zatem śmierć nie tylko koni przebywających w mieście, lecz także w znacznym stopniu tych frontowych, kawaleryjskich, biorących udział w obronie Warszawy. Wiele z nich padło na polu walki z wycieńczenia, podczas przemarszów bądź w wyniku odniesionych ran w trakcie ostrzałów i bombardowań. Historie te jednak pozostają w dużej mierze nierozpoznane - „Po klęsce wrześniowej w roku 1939 o dalszym losie ludzi wiadomo dużo [...], natomiast o tym, co się stało z końmi, właściwie niewiele”23.

\section{„Korowód" ludzi i zwierząt}

Naloty wywoływały chaos wśród ludzi i powodowały dezintegrację przestrzeni miasta. W pierwszych dniach września, kiedy niemieckie oddziały pancerne nacierały z zachodu na Warszawę, zaczął się gorączkowy ruch ludności. Mieszkańcy zabierali swój dobytek i kierowali się ku mostom na Wiśle, by przedostać się następnie na szosę lubelską. Warszawa była wówczas miastem w ruchu, tranzytowym, o ogromnym zagęszczeniu ludzi oraz zwierząt. Konie ciągnące obładowane wozy odgrywały w transporcie istotną rolę, dlatego warto przyjrzeć się im bliżej. Zdzisław Żórawski odnotował w Dzienniku, że „niesamowity widok przedstawiało Śródmieście", gdzie:
\end{abstract}

[...] z długimi szeregami chłopskich wozów, często wiozących skromny dobytek - mieszają się staroświeckie landary folwarczne, powyciągane z zapadłych kątów prowincji, eleganckie powoziki, i gdzieniegdzie nawet samochód, ciągnięty przez konie, by zaoszczędzić benzynę $e^{24}$.

Przez miasto przetaczał się orszak ludzi i zwierząt, „tłumy uciekinierów szły bez końca”, dookoła „rozlegał się stukot kopyt końskich”25. Żórawski dostrzegł także w tym „korowodzie” stado koni - pochodzących najprawdopodobniej z dobrej hodowli - prowadzonych przez młodą kobietę i kilku stajennych. Przybyli oni aż z okolic Poznania, „uciekając to spod ognia karabinów maszynowych, to spod bomb lotniczych", i udawali się w stronę Wisły, by szukać schronienia dla koni ${ }^{26}$.

Stolica stała się epicentrum zniszczenia, ale nie była izolowaną przestrzenią bombardowania, należy spojrzeć na Warszawę także przez pryzmat bezpośrednich okolic, ma-

\title{
Po bombardowaniach miejskie krajobrazy
} zamieniały się w ruiny, pod gruzami ginęli nie tylko ludzie, lecz także zwierzęta, rzadko ujmowane jednak w statystykach. Ich śmierć nadal pozostaje tematem sytuującym się na obrzeżach dyskursu o działaniach wojennych. zowieckich miasteczek i wsi. Żórawski, udając się do Lublina, na kartach swojego Dziennika zabiera czytelnika w podróż przez „krajobraz po bitwie”, gdzie ofiarami były również zwierzęta. Dowiadujemy się, że od tej pory przejazd był utrudniony: „Jedziemy z wolna szosą, niejednokrotnie z trudem mijając ciągnące wozy, uciekinierów, gęsto spotykając po drodze rozbite samochody, poprzewracane wozy, trupy koni i popalone domy dróżników"27. Drogi były pokryte martwymi zwierzętami, a spalone bądź palące się wioski, miasteczka oraz lasy ciągnęły się na przestrzeni stu kilometrów aż do samego Lublina. Podobny obraz przedstawiała w Dziennikach czasu wojny Zofia Nałkowska. Opisała ona drogę, jaką przebyła w przeciwnym kierunku, z Lublina do Warszawy, już po kapitulacji stolicy. Wiele miejsca poświęciła koniom oraz trudom podróży, jakie znosiły: 
Małe chłopskie koniki, wózki, wyładowane po wierzch rupieciami, tobołkami i ludźmi, musiały przekopywać się przez piach bocznej dróżki. Tworzyły się zatory, gdy jeden zmordowany koń przystanął, nie można go było bowiem wyminąć, nie wjeżdżając na kamienny pas szosy ${ }^{28}$.

Zdarzało się, że konie musiały ciągnąć obładowane wozy przez pola, by ustąpić miejsca wojskom przechodzącym główną drogą. Poruszanie się po piaszczystym, miękkim podłożu zwiększało ich wysiłek, co dostrzegała również sama pisarka:

Konie skręcają wprost w wyjeżdżony już rów, koła obracają się w powietrzu, ludzie zeskakują w biegu, przytrzymując lecące toboły, podpierając przechylone wozy. Koniki kopią się grząską drogą w poprzek zagonów, wloką swój ciężar przez mokre łączki, całymi kilometrami jadąc tak wzdłuż wysokiej szosy, na którą w jakimś miejscu będzie znów wolno powrócić. Idziemy piechotą za wozem, na którym została tylko doktorowa ${ }^{29}$.

W pochodzie wozów zaprzężonych w często zmęczone konie mijała ona wsie, w których spalone zostały nie tylko zabudowania wraz z drzewami, lecz także zwierzęta. Makabryczny widok wyłaniał się z opisu mazowieckiej osady, nad którą unosił się zapach martwych zwierząt:

Tu i owdzie ocalały domek jeszcze stoi w swoim ogródku. Drzewa osmalone, zwarzone liście, jakaś brzoza ma pień zupełnie czarny i rude listki. Zgliszcza bez komina pośrodku oznaczają zabudowania gospodarskie. W jednym czarnym prostokącie dziobią coś kury, zalatuje padliną, widać jakieś czarno-czerwone wzniesienie. To spalony w zamkniętej stajni koń. Gdzieś dalej to, co zostało, podobne jest raczej do krowy. Osmalone ogrodzenie uratowano od pożaru, wyłamując płonące paliki. To jednak, co pozostało, nie ochrania już nic ${ }^{30}$.

Ten zatrważający opis uświadamia natomiast, jak mało wiemy o śmierci zwierząt gospodarskich w samej Warszawie, gdzie znajdowały się rzeźnie, krowiarnie czy przydomowe hodowle. Według statystyk w dniu wybuchu wojny w granicach Warszawy było bowiem 8000 koni, 3000 krów, 1000 świń i 1000 kóz $z^{31}$.

\section{Wojenna egzotyzacja ulic}

Podczas nalotów poważnie ucierpiał warszawski ogród zoologiczny. Przebywające w nim zwierzęta były całkowicie uzależnione od ludzkiej opieki. Antonina Żabińska, żona dyrektora zoo, wspomina, że wojna wywoływała w niej strach, gdyż martwiła się o podopiecznych, „chodziło o los istot żywych, zdanych na człowieka, zależnych od niego w stopniu

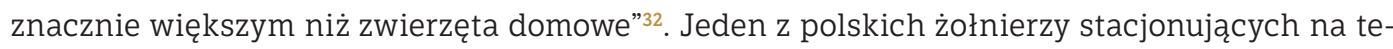
renie ogrodu odnotował: „Żal mi było zwierząt, tych naszych «młodszych braci» ponoszących niezawinione konsekwencje ludzkich walk. Głodne to było, poranione, cierpiące, bezradne" ${ }^{33}$. Tak opisuje on zachowanie niedźwiedzia:

Podczas nalotu na baterie, gdy skoczyliśmy do rowu, z rozbitej klatki wypadł oszalały ze strachu malajski niedźwiedź, szukał biedak dziury, by się schować przed tym, co się działo, a czego nie mógł pojąć. Wpadł do naszego rowu tarmosząc stojących przed nim kanonierów, szczęściem chwytał za torby masek przeciwgazowych $[\ldots]^{34}$.

Inny żołnierz wspominał, że „przykrym też obrazem dla nas żołnierzy był smutny los koni głodnych, pokaleczonych lub zabitych"35. Zakopywali oni na terenie ogrodu zoologicznego martwe konie, które „leżały z brzuchami wzdętymi, z wyszczerzonymi zębami; w szeroko otwartych oczach miały zastygły wyraz przerażenia" ${ }^{36}$. 
Zdaniem Żabińskiej po kapitulacji Warszawy zrobiło się „tragicznie pusto bez zwierząt”. Przed wybuchem wojny w ogrodzie zoologicznym przebywało ich bowiem około 1000 , z czego zginęło blisko $800 \mathrm{z}$ nich ${ }^{38}$. W trakcie nalotów bombowych szympansy i ptaki egzotyczne spłonęły razem z pawilonem, śmierć poniosła także część małp, antylop, słoni oraz białych niedźwiedzi. Jedna z żyraf została zabita, druga się uratowała. Osły i kuce padły na szosie w czasie przeprawy na Bielany zainicjowanej przez jednego z urzędników zarządu miasta. Ocalały natomiast hipopotamy, niedźwiedzie, żubry, bizony, łosie i rysie. Co ciekawe, wydry i bobry pozostały w swoich basenach, natomiast foki uciekły ${ }^{39}$. Jak relacjonował Jan Żabiński w piśmie „Stolica”, dostały się one lądem do Wisły i spłynęły do Bałtyku ${ }^{40}$. Wiele też zwierząt się zgubiło, jak borsuki i srebrne lisy. Ponadto jelenie, lamy oraz wielbłądy błąkały się później nad Wisłą. Kazimierz Albert, żołnierz z batalionu odpowiedzialnego za obronę miasta, widział na wysokości mostu Poniatowskiego egzotyczne ptaki pochodzące z zoo:

Po raz pierwszy zetknąłem się ze zwierzętami z ZOO w rejonie mostu Poniatowskiego (po lewej stronie, patrząc w kierunku zachodnim). Zauważyłem wówczas kilkadziesiąt sztuk ptaków brodzących jak flamingi, czaple, żurawie, bociany i inne, które musiały pochodzić z ZOO. Ptactwo żerowało nad brzegiem Wisły, nie wykazując zaniepokojenia obecnością ludzi ${ }^{41}$.

Innym razem ten sam żołnierz zauważył na jednej z praskich ulic wystraszone antylopy uciekające przed ludźmi i hukiem wybuchów:

Drugi obraz, który mi utkwił w pamięci, to przebiegające ulicą Zygmuntowską ${ }^{42}$ dwie piękne antylopy. Zwierzęta miotały się tam i z powrotem przestraszone widokiem ludzi i hukiem wybuchających pocisków artylerii. Na terenie ZOO, gdzie mieściła się część mego taboru i innych oddziałów, widziałem różne zwierzęta (nie drapieżniki - uprzednio już zgładzone), które przeważnie swobodnie się poruszały i były dokarmiane przez żołnierzy z oddziałów tam przebywających ${ }^{43}$.

Jan Żabiński miał już wcześniej przygotowaną na wypadek wojny listę zwierząt do odstrzału, które mogły stanowić zagrożenie dla ludzi. W ramach racjonalnego, strategicznego planowania część z nich została zabita w celu zapewnienia mieszkańcom bezpieczeństwa i ochrony przed zwierzętami drapieżnymi. Egzekucje na około pięćdziesięciu z nich zostały wykonane na samym początku oblężenia, do 3 września 1939 roku. Tragizm tego typu decyzji oddany został między innymi w opowiadaniu Kornela Filipowicza Egzekucja w zoo oraz filmie na jego podstawie w reżyserii Jana Rutkiewicza o tym samym tytule, które bazują na autentycznych wydarzeniach. Za pomocą oszczędnych środków przedstawiono nieuchronny, dramatyczny los zwierząt z wrocławskiego ogrodu zoologicznego pod koniec wojny i kapitulacji miasta, gdy musiały zostać uśmiercone. Dyrektor zoo w rozmowie z dowództwem SS próbował, choć bezskutecznie, odwołać się od rozkazu, by ratować zwierzęta. Padają wówczas znamienne słowa: „- Pan mówi o zwierzętach, kiedy giną ludzie? Człowieku. - Ale zwierzęta, zwierzęta są niewinne. - A ludzie są winni, tak?". Tego typu historie pokazują wyraźnie, że definicja ofiar wojennych wymaga rozszerzenia, uwzględnienia istot pozaludzkich oraz kontekstów relacji międzygatunkowych.

Wojenne wywrócenie porządku i wydostanie się zwierząt egzotycznych na ulice bądź przeciwnie, zabijanie ich, pokazuje, jak nie przystają one do rzeczywistości miejskiej. Dekontekstualizacja zwierząt, osadzenie ich w innej przestrzeni, gdy nagle opuszczają zaprojektowany i zamknięty teren, ujawnia w istocie sztuczność idei ogrodu zoologicznego. Zwierzęta te wydają się „nie na swoim miejscu” w przestrzeni miasta, gdzie na wolności stanowią zagrożenie dla ludzi, tak tłumnie przybywających przed wojną do ogrodu, by podziwiać je z bezpiecznej pozycji obserwatora.

Około stu zwierząt różnych gatunków, które przetrwały oblężenie - uznanych za najcenniejsze przez nazistów z Lutzem Heckiem na czele, odpowiadającym w Trzeciej Rzeszy za „całokształt zagadnień przyrodniczo-łowiecko-zoologicznych"44 - wywieziono do ogrodów na terenie Niemiec. W taki też sposób słonica Tuzinka trafiła do Królewca, wielbłądy i lamy do Hanoweru, 
konie Przewalskiego do Wiednia, rysie i żubry do Schorfheide, a hipopotamy do Norymbergi ${ }^{45}$. Z kolei ptaki z warszawskiego ogrodu zoologicznego zostały rozstrzelane przez niemieckich żołnierzy, którzy na jego terenie urządzili polowanie. W ten sposób zginęły między innymi orzeł i dwa sępy. Przez kilka miesięcy po kapitulacji Warszawy krążyły jeszcze nad zwierzyńcem, „mimo odzyskanej wolności nie chciały porzucić swej siedziby” ${ }^{46}$. Ci „ostatni Mohikanie” - jak określiła je Antonina Żabińska - przylatywali po pozostawione w ogrodzie ochłapy końskiego mięsa do czasu, aż w noc sylwestrową 1939 roku stali się trofeami myśliwskimi dla Niemców.

W.G. Sebald, piszący z kolei o bombardowaniu zoo w Berlinie oraz o makabrycznych obrazach i opisach martwych lub rannych zwierząt utrwalonych w literaturze wspomnieniowej, stwierdza, że mogą one wzbudzać grozę, ponieważ „[...] przełamują poniekąd z góry cenzurowane, stereotypowe relacje o cierpieniach ludzi”. Dodaje także, że przyczyną może być „pamięć o tym, że ogrody zoologiczne, które w całej Europie wywodzą się z potrzeby demonstrowania książęcej i imperialnej potęgi, miały zarazem na swój sposób odzwierciedlać ogród rajski”"47. Wojna zmienia jednak dotychczasowe wyobrażenia, obnaża względność ludzkich założeń i kategoryzacji. Skonfiskowana przez Niemców część zwierząt, uznanych za najważniejsze ze względu na ich wartość hodowlaną czy wystawienniczą, stała się zdobyczą wojenną, wzbogacającą kolekcje ogrodów Trzeciej Rzeszy ${ }^{48}$. Świadczy to zatem o żywotności dawnej funkcji zwierzyńców, na przykład pierwszych menażerii królewskich, które miały stanowić o sile i prestiżu danego państwa. Wraz z rozwojem ogrodów zoologicznych idea ta była wypierana, zmieniały się oficjalne zadania, jakie miały one spełniać - od drugiej połowy XIX wieku podkreślano bowiem ich rolę edukacyjną i naukową ${ }^{49}$. Innym z kolei przykładem rekontekstualizacji, sytuowania zwierząt z zoo bliżej komercyjnej i cyrkowej roli, jest historia wielbłąda Grzesia. W trakcie oblężenia został on zabrany z terenu warszawskiego ogrodu przez jednego z pielęgniarzy. Widywany był później na ulicach miasta w czasie okupacji,wynajmowano go firmie reklamującej różne towary.

\section{Ikoniczne obrazy. Podsumowanie}

Martwe zwierzęta wśród gruzów pojawiają się w ikonografii Warszawy z czasów kampanii wrześniowej, ale nie wpisały się w dominujący obraz zniszczonego miasta. Jak podkreśla Łukasz Gorczyca, jeden z redaktorów albumu Ruiny Warszawy, „chociaż wszystkie zburzone miasta wydają się na swój sposób podobne, kontekst ich obrazowania bywał bardzo różny”50. I tak na przykład wyszczególnia on warszawskie ruiny triumfalne, traumatyczne i sentymentalne. Obrazy zniszczonej Warszawy z okresu Wielkiej Wojny związane były z bezpośrednim odzyskaniem przez Polskę niepodległości, towarzyszyły im pozytywne emocje, odmiennie niż w przypadku ruin będących skutkiem II wojny światowej. Bombardowanie miasta okazało się traumatycznym doświadczeniem dla ludzi, dlatego „od czasów ostatniej wojny w fotografie stołecznych ruin wpisane są tragizm i poczucie dramatycznej straty - zagłady ludności i tkanki materialnej miasta. Ta klisza rzutuje również na widok współczesnych ruin [...]”11. Zwierzęta rzadko są jednak przywoływane w kontekście bombardowań, mimo to jedne z najbardziej rozpoznawalnych fotografii wojennej Warszawy przedstawiają chłopca z kanarkiem w klatce na gruzach miasta. Serię zdjęć wykonał Julien Bryan, amerykański dokumentalista, a chłopiec to, jak się udało później ustalić, dziewięcioletni wówczas Zygmunt Aksenow, mieszkający w okolicy Starego Miasta, gdzie też zostały zrobione fotografie ${ }^{52}$. Obraz dziecka oraz uratowanego przez niego ptaka jawi się jako wyjątkowy pośród innych przedstawień miasta, wiąże się także z silnym przekazem emocjonalnym. Odsyła bowiem do zniszczenia i niezawinionego cierpienia, jakie było udziałem ludzi, oraz skłania do refleksji nad losem zwierząt w czasie bombardowań. Jak można przeczytać w literaturze dokumentu osobistego, często podkreślano bezbronność i bezradność zwierząt wobec sytuacji zewnętrznej, całkowicie od nich niezależnej. Należy więc mówić o wojennym doświadczeniu zarówno ludzi, jak i zwierząt, bo bez wątpienia także one, choć nie mamy do tego dostępu, odczuwały zmianę, stres czy lęk. 


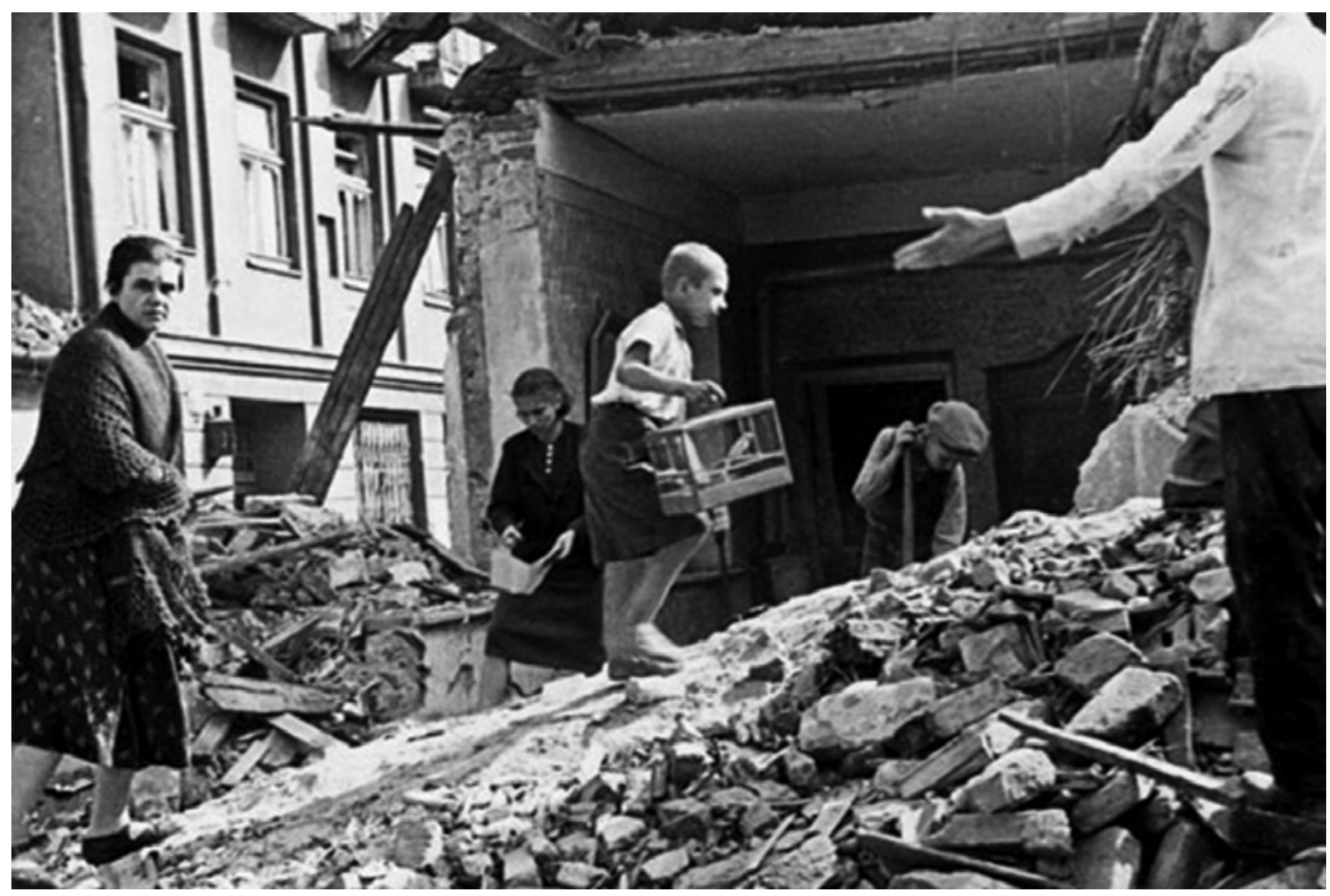

Chłopiec z kanarkiem, wrzesień 1939 roku. Fot. Julien Bryan ŹRÓDŁO: WIKIMEDIA COMMONS

Cała historia udomowienia i hodowli zwierząt jest złożonym zjawiskiem, ale bez wątpienia jednym z jego wymiarów było uzależnianie istot pozaludzkich od ludzkich ${ }^{53}$. Wojna tym bardziej odsłania mechanizmy kulturowe i wyostrza silne przywiązanie zwierząt do człowieka. Będąc dotychczas przedmiotem jego troski, w sytuacji wojennej, kiedy nie mogą otrzymać należytej opieki, stają się zagrożone. Zapis niepokoju o zwierzęta w czasie kampanii wrześniowej odnajdziemy między innymi w Dzienniku Zofii Nałkowskiej. Przed opuszczeniem Warszawy we wrześniu zmuszona została ona do przekazania przez służącą swoich papug do sklepu, gdzie je wcześniej zakupiła. Później zanotowała: „Myślę, jak wygląda zwalony dom, obnażone ściany, przedmioty pod gołym niebem. W tej wielkiej klęsce rzecz drobna, o której nie śmiem myśleć, tak jest straszna: ptaszki” ${ }^{4}$. Po powrocie do stolicy w październiku zwierzała się natomiast: „Na próżno stukałam i pytałam u sąsiadów. [...] Nie dowiedziałam się więc niczego o ptakach, nie wiem, czy żyją"55.

Wojnę można zdefiniować za Ludwikiem Stommą jako „zabójczą, przerażającą grę, jej zasady mają się nijak do cywilno-pokojowych dekalogów, praw człowieka i obywatela zawartych w tamtym odległym, przedwojennym czasie umów, przysiąg, zobowiązań" ${ }^{6}$. Podobnie jest ze zwierzętami, które w trakcie konfliktów zbrojnych wystawione na działania wojenne, pozbawione są często podstawowych praw, także tych wynikających z konkretnych aktów normatywnych. Chociażby warszawskie Towarzystwo Opieki nad Zwierzętami na czas okupacji znacznie ograniczyło swoją działalność, jego członkowie zajmowali się ratowaniem bezdomnych psów i kotów oraz udzielali pomocy wyniszczonym koniom na tyle, na ile było to możliwe ${ }^{57}$. Wojna przynosiła niejako równość wobec śmierci, gdy ginęli ludzie oraz ich zwierzęta, jak i nieco przesuwała akcenty - ginęły zwierzęta i ich ludzie, którzy nie zawsze potrafili zapewnić im należytą opiekę ${ }^{58}$. Przed bombardowaniami nie można było się uchronić, ofiary były masowe. Naloty powietrzne przynosiły śmierć cywilów, kobiet i dzieci. Podział na front został zniesiony, umierali lub odnosili rany już nie tylko żołnierze i zwierzęta zwerbowane do wojska, wykorzystywane na polu walki, lecz także ludność cywilna oraz zwierzęta pozawojskowe na ulicach, podwórzach czy w ogrodach zoologicznych. Była to niewątpliwie zmiana, jaka dokonała się w czasie II wojny światowej, stanowi ona jeden z pomijanych jak dotąd argumentów potwierdzających jej totalność. 


\section{PRZYPISY}

1 Artykuł powstał w ramach realizacji projektu badawczego "Historia środowiskowa okupowane i powojennej Warszawy (1939-1947)", finansowanego przez Narodowe Centrum Nauki (nr 2018/31/N/ HS3/02127)

2 J. Leociak, Doświadczenia graniczne. Studia o dwudziestowiecznych formach reprezentacji, Warszawa 2008, s. 133

3 Tamże, s. 145-146

4 T. Szarota, Naloty na Warszawę podczas II wojny światowej, w: tenże, Karuzela na placu Krasińskich. Studia i szkice z lat wojny i okupacji, Warszawa 2007, s. 339.

5 J. Leociak, Doświadczenia graniczne..., dz. cyt., s. 155

6 NN, Warszawa w ogniu. Kronika dni wrześniowych, zestawił Nemo (Halszka Buczyńska), Warszawa 1942 s. 5. Cyt. za T. Szarota, Naloty na Warszawę..., dz. cyt., s. 337. W publikacji zebrano materiały przesłane na konkurs pamiętnikarski „Biuletynu Informacyjnego”.

7 H. Regulska, Dziennik z oblężonej Warszawy, Warszawa 1978, s. 21, 35. Cyt. za T. Szarota, Naloty na Warszawę..., dz. cyt., s. 337.

8 T. Szarota, Naloty na Warszawę..., dz. cyt., s. 349.

9 Tamże.

10 J. Leociak, Doświadczenia graniczne..., dz. cyt., s. 133-134

11 W.G. Sebald, Wojna powietrzna i literatura, przeł. M. Łukasiewicz, Warszawa 2012, s. 36

12 K. Brandys, Miasto niepokonane. Opowieść o Warszawie, Warszawa 1947, s. 278

13 È. Baratay, Zwierzęcy punkt widzenia. Inna wersja historii, przeł. P. Tarasewicz, Gdańsk 2014, s. 275. Zob. także inną książkę tego autora: Zwierzęta w okopach. Zapomniane historie, przeł. B. Brzezicka, Gdańsk 2017.

14 Tamże.

15 Konie w Warszawie. Katalog wystawy 5 marca-30 sierpnia 2015, oprac. H. Polańska, Warszawa 2015, s. 17.

16 Zob. Ł. Sobechowicz, Konie Warszawy - historia w liczbach „Almanach Muzealny” 2014, t. 8; tenże. Konie i pojazdy mechaniczne w Warszawie do 1939 roku, "Przegląd Historyczny” 2013, t. CIV, z. 2

17 Z. Żórawski, Dziennik obrońcy Warszawy. Wrzesień 1939 r., wstęp. T. Szarota, Warszawa 2011, s. 85.

18 Tamże, s. 89.

19 L. Landau, Kronika lat wojny i okupacji, t. 1: Wrzesień 1939-listopad 1940, Warszawa 1962, s. 17

20 Z. Żórawski, Dziennik obrońcy..., dz. cyt., s. 89.

21 A. Wrońska (red.), Nieba i ziemi nie widać. Warszawiacy o wrześniu 1939, Warszawa 2019, s. 55. Fragment ze wspomnień Stanisława Poraya-Wilczyńskiego przesłanych na konkurs Pamiętnik warszawiaka zorganizowany w 1948 roku. Na stronie tytułowej: Pamiętnik adwokata warszawskiego od dnia 28 sierpnia 1939 do połowy 1945 roku.

22 Z. Żórawski, Dziennik obrońcy..., dz. cyt., s. 85.

23 P. Jaźwiński, Oficerowie i konie. Przyjaźń na śmierć i życie. Kawalerzyści Drugiej Rzeczpospolitej o koniach - swoich towarzyszach broni, Warszawa 2012, s. 183

24 Z. Żórawski, Dziennik obrońcy..., dz. cyt., s. 56.

25 Tamże, s. 57.

26 Tamże, s. 56.

27 Tamże, s. 65.

28 Z. Nałkowska, Dzienniki czasu wojny, oprac. H. Kirchner, Warszawa 1972, 4.10.1939.

29 Tamże, s. 72.

30 Tamże, s. 66.

31 Raport o stratach wojennych Warszawy, Miasto Stołeczne Warszawa, Warszawa 2004.

32 A. Żabińska, Ludzie i zwierzęta, Kraków 2017, s. 24

33 Ludzie i zwierzęta pod pociskami, „Stolica” 1968, nr 1, s. 5. Wspomnienia por. Borkowskiego.

34 Tamże.

35 Tamże. Wspomnienia mjr. Kazimierza Alberta. 
36 A. Żabińska, Ludzie i zwierzęta, dz. cyt., s. 37-38.

37 Tamże, s. 37.

38 W. Sachs, Warszawski ogród zoologiczny, "Stolica” 1950, nr 43, s. 3.

39 A. Żabińska, Ludzie i zwierzęta, dz. cyt., s. 31.

40 Ludzie i zwierzęta..., dz. cyt., s. 5. Relacja Jana Żabińskiego.

41 Tamże. Wspomnienia mjr. Kazimierza Alberta.

42 Dziś aleja Solidarności, odcinek od mostu do ulicy Targowej.

43 Ludzie i zwierzęta..., dz. cyt., s. 5. Wspomnienia mjr. Kazimierza Alberta.

44 Tamże, s. 42.

45 Tamże, s. 45.

46 Tamże.

47 W.G. Sebald, Wojna powietrzna..., dz. cyt., s. 110.

48 Na temat stosunku Trzeciej Rzeszy do zwierząt zob. B. Sax, Animals in the Third Reich: Pets, Scapegoats, and the Holocaust, London-New York 2000.

49 O ogrodach zoologicznych i historycznych zmianach ich funkcji na przykładzie warszawskiego zoo piszę w artykule: "Zielone miasto” atrakcji, zwierzęta i nowoczesność. Powstanie warszawskiego ogrodu zoologicznego w odrodzonej Polsce, „Adeptus" 2018, nr 12

50 Ł. Gorczyca, Wstęp w: Ruiny Warszawy. Fotografie z lat 1915-2016, oprac. Ł. Gorczyca, M. Kaczyński, Warszawa 2016, s. 8

\section{Tamże.}

52 Zob. Chłopiecz kanarkiem, https://whu.org.pl/2019/09/08/chlopiec-z-kanarkiem/(dostep:10.03.2020). Jako kontekst warto wskazać jedno z najbardziej rozpoznawalnych zdjęć z getta warszawskiego, zamieszczone w raporcie Jürgena Stroopa. Przedstawia ono żydowskiego chłopca z uniesionymi rękami w geście poddania się niemieckim żołnierzom w czasie powstania w dzielnicy zamkniętej w 1943 roku.Na temat powojennej historii tego zdjęcia i próbie ustalenia tożsamości chłopca zob. Frédéric Rousseau, Żydowskie dziecko z Warszawy. Historia pewnej fotografii, przeł. T. Swoboda, Warszawa 2012.

53 Zob. A. Lasota-Moskalewska, Zwierzęta udomowione w dziejach ludzkości, Warszawa 2005.

54 Z. Nałkowska, Dzienniki czasu wojny, dz. cyt., 22.09.1939.

55 Tamże, 10.10.1939.

56 L. Stomma, Antropologia wojny, Warszawa 2014, s. 13

57 Strona warszawskiego Oddziału Towarzystwa Opieki nad Zwierzętami w Polsce, http://www.warszawa.toz.pl/o_nas.html (dostęp: 18.02.2020).

58 Por. tytuł książki: A. Barcz, D. Łagodzka (red.), Zwierzęta i ich ludzie. Zmierzch antropocentrycznego paradygmatu, Warszawa 2015 



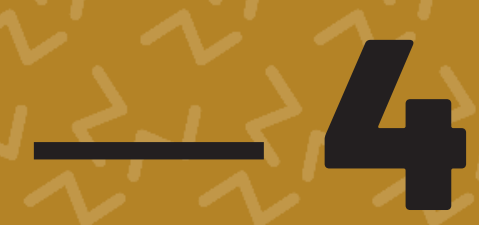

Recenzje

i omówienia 


\section{Justyna Schollenberger}

\section{Niebezpieczne związki - Tora Holmberg o miejskich zwierzętach}

Tora Holmberg ${ }^{1}$, Urban Animals. Crowding in Zoocities, London-New York 2015, ss. 164.

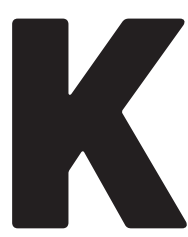

eith Thomas w klasycznym opracowaniu Man and the Natural World dotyczącym przemian zachodniego stosunku do zwierząt i natury pisze o pożałowania godnym losie współczesnego psa sprowadzonego do roli ukochanego pupila (pet). Oto wy-

kastrowany, zostawiany samotnie na wiele godzin, pozbawiony możliwości swobodnego ruchu oraz towarzystwa pobratymców i skazany na ścisłe więzi z człowiekiem, żyjący nie wśród lasów i łąk, ale w środku „miejskiej dżungli, wymownie świadczy o stanie zatomizowanego zachodniego społeczeństwa"2. Cóż z tego, że ma zapewnione wszelkie wygody, regularnie podawane posiłki, obdarzany jest wysokim statusem członka rodziny i gorącymi uczuciami swoich ludzkich opiekunów, skoro płaci za to wysoką cenę utraty swojej zwierzęcej (a więc, w domyśle, dzikiej lub wolnej) natury. Myśl zachodnia, jak pisze Kari Weil, podchodzi do zwierząt domowych (szczególnie do psów) z programową nieufnością. Zbyt blisko związały się z człowiekiem, by mogły być traktowane jak zwierzęta autentyczne ${ }^{3}$. Ich domniemana prawdziwa natura została skutecznie zagłaskana na śmierć przez stęsknionych bezinteresownej miłości właścicieli, którzy z kolei sami utracili zdolność do nawiązania pełnych i bliskich relacji z drugim człowiekiem. Nie wiadomo w gruncie rzeczy, czyj los jest smutniejszy: psa w ciasnym mieszkaniu czy osamotnionego człowieka, którego bliskim towarzyszem stało się zwierzę.

Tora Holmberg w wydanej w 2015 roku książce Urban Animals zajmuje się właśnie skomplikowanymi związkami ludzi oraz zwierząt w tak zwanej miejskiej dżungli. Skupia się na przypadkach, które z łatwością mogłyby zostać potraktowane jako ilustracje wyżej zaprezentowanego obrazu zwierząt towarzyszących i ich właścicieli. Bada oblicza konfliktu o psią plażę, problem miejskich bezdomnych kotów i ich opiekunów, by następnie przejść do „szalonych kociar” [crazy cat lady] i „zbieraczek zwierząt” [animal hoarders]. Holmberg proponuje jednak o wiele ciekawszy, a także prowokujący do namysłu obraz relacji pomiędzy ludźmi i zwierzętami. Nie pisze więc de facto o żadnej miejskiej dżungli, ale o tytułowych „zoomiastach” [zoocities]. Zwierzęta w mieście w pewnym sensie są nie na swoim miejscu; dopuszczamy je do przebywania w wyznaczonej przestrzeni miejskiej na ściśle określonych zasadach albo po prostu, jeśli uznamy je za szkodniki, wyganiamy, tępimy. Zwierzęta towarzyszące, ściśle związane z człowiekiem, funkcjonujące nawet na prawach członka rodziny, zaburzają zaś tradycyjną dychotomię kultura-natura; równie dobrze mogą być potraktowane jako niemal pełnoprawni użytkownicy przestrzeni miejskiej lub jako istoty dzikie, zagrażające społecznemu ładowi. Badaczka pokazuje między 
innymi, w jaki sposób liminalny status psów i kotów prowokuje określone praktyki społeczne oraz więzi ludzko-zwierzęce, jakim regulacjom prawnym podlega, a przede wszystkim, jakie społeczne wyobrażenia uznawanej za poprawną relacji człowiek-zwierzę ujawnia i w jaki sposób może je podważać.

Łączenie namysłu nad przestrzenią miejską i relacjami ludzko-zwierzęcymi jest znakiem firmowym szwedzkiej badaczki. Tora Holmberg pracuje na Wydziale Socjologii na Uniwersytecie w Uppsali. Jej dotychczasowe prace, dostępne w języku szwedzkim i angielskim, sytuują się na przecięciu studiów miejskich, socjologii, studiów nad nauką i technologią, animal studies, kulturoznawstwa i feminizmu. Urban Animals jest doskonałym przykładem na to, że namysł nad relacjami międzygatunkowymi wymaga języka interdyscyplinarnego. Rzeczywistość, którą pragniemy tu opisać, z trudem bowiem można oddać w dostępnych nam tradycyjnych dualizmach człowiek-zwierzę, dzikieoswojone, kultura-natura. Holmberg zdecydowanie opowiada się za namysłem pozbawionym „dywizów”, to znaczy takim, który stara się już na poziomie użytej terminologii podkreślać przenikanie się tego, co ludzkie i zwierzęce, naturalne i kulturowe. Posługuje się więc pojęciami takimi jak „naturokultura” za Donną Haraway ${ }^{4}$ czy

Przestrzeń miejska każe nam, ludziom i zwierzętom, tłoczyć się razem, walczyć o miejsce, wchodzić ze sobq w konflikty, ale też pozwala wypracowywać nowe modele współistnienia, w których, co istotne, sprawczość przypisywana jest także zwierzętom. „ludzkozwierzęce” [humanimal], a w wyjątkowo ciekawych analizach statusu kotów w szwedzkich miastach zachęca, by raczej mówić o „kot-egoriach” [cat-egories] niż „kategoriach” (oczywiście widać tu, że gest rezygnacji z dywizów należy traktować bardziej symbolicznie niż dosłownie).

Urban Animals składa się z trzech części i siedmiu rozdziałów. Pierwszy z nich pełni rolę teoretyczno-metodologicznego wstępu. Pozostałych sześć rozdziałów składa się na trzy główne części książki, które są zatytułowane kolejno Animals in the City (Zwierzęta w mieście), Humanimal Transgressions (Ludzkozwierzęce transgresje) oraz The Promises of Crowding in Zoocities (Obietnice płynące ze stłoczenia w zoomiastach) ${ }^{5}$. Holmberg pokazuje, dlaczego zjawisko stłoczenia oraz sam tłum, nieodłącznie związane z miastem, mogą okazać się tak owocne w badaniach relacji międzygatunkowych. W jej analizach pejoratywny charakter stłoczenia w miastach jako zjawisko niepożądane i jednocześnie nieuniknione łączy się z namysłem nad potencjałem politycznym międzygatunkowych kolektywów. Przestrzeń miejska każe nam, ludziom i zwierzętom, tłoczyć się razem, walczyć o miejsce, wchodzić ze sobą w konflikty, ale też pozwala wypracowywać nowe modele współistnienia, w których, co istotne, sprawczość przypisywana jest także zwierzętom.

Pierwszy rozdział zatytułowany Urban Animals (Miejskie zwierzęta) wprowadza czytelnika w przedstawianą problematykę oraz przyjętą metodę badawczą autorki. Holmberg zainteresowana jest podejściem hybrydalnym, w centrum stawiającym namysł nad tym, co „więcej-niż-ludzkie" [more-than-human]. Uznając, że namysł nad zwierzętami skazany jest na antropocentryzm (nie wyzbędziemy się bowiem własnej perspektywy poznawczej), autorka decyduje się na pisanie nie tyle o zwierzętach, ile „w pobliżu” zwierząt [„,nearby” animals]. Przyjęcie takiej metodologii oznacza swoiste pogodzenie się z nieuchronną porażką związaną z niemożliwością pełnego przedstawienia zwierząt (takiego, jakie rzeczywiście zdawałoby sprawę ze „zwierzęcego punktu widzenia”), które jednak nie prowadzi do porzucenia kwestii zwierzęcej. Autorka pisze, że chce dążyć do przedstawienia zwierząt poprzez „[...] skupienie się na relacyjności ludzi i innych zwierząt”. Jak wskazuje: 
[...] jeśli humanizm oznacza odrzucenie wszystkiego, co nie-ludzkie, to więcej-niż-ludzkie opiera się nie na wykluczaniu ludzi lub ludzkich doświadczeń, ale na de-centralizowaniu ich na rzecz gatunkowej relacyjności. [...] Nie wylewam człowieka z kąpielą, ale utrzymuję empiryczne skupienie na ludzkim działaniu i doświadczeniu, a ludzkozwierzęce (humanimal) relacje stanowią punkt dojścia analiz ${ }^{6}$.

Kluczowa dla jej namysłu nad międzygatunkowymi relacjami jest koncepcja Donny Haraway, która podkreśla, że naszą tożsamość zyskujemy wyłącznie dzięki wchodzeniu w relacje z innymi (również zwierzętami i innymi bytami pozaludzkimi). Wszyscy, ludzie i nie-ludzie, jesteśmy dla siebie nawzajem „bytami-w-spotkaniu” [beings-in-encounter], „gatunkami towarzyszącymi" [companion species]. W tym sensie człowiek rozumiany jako autonomiczny i oddzielony od porządku naturalnego podmiot nie istnieje, nie zajmuje też w świecie pozycji centralnej. Nie da się więc myśleć o nim, ale też o społeczeństwie, abstrahując od naszych relacji z innymi gatunkami. Taki, już posthumanistyczny, a nie humanistyczny, namysł powinien uwzględniać sieć skomplikowanych więzi, interakcji, związków pomiędzy „gatunkami towarzyszącymi”.

Holmberg interesuje to, jak przestrzeń miejska oraz zjawisko ludzkozwierzęcego stłoczenia [humanimal crowding] reguluje i prowokuje międzygatunkowe relacje i nowe ludzkozwierzęce tożsamości. W swoich analizach łączy klasyczne teorie z zakresu socjologii miasta spod znaku Georga Simmela czy Henriego Lefebvre'a z refleksją posthumanistyczną.

Odnosząc się do myśli Lefebvre’a, badaczka traktuje przestrzeń miejską raczej jako „[...] proces i punkt węzłowy wielogatunkowych polityk [multi-species politcs] niżjako konkretną formę"” . Te wielogatunkowe polityki bada w kontekście zjawiska stłoczenia (crowding), uzupełniając tę znanąz badań urbanistycznych kategorię o znaczenie „,kolektywu”, wyzyskiwane w teoriach posthumanistycznych inspirowanych myślą Donny Haraway czy teorią Gilles’a Deleuze'a i Félixa Guattariego). Chodzi jej o uchwycenie miasta jako przestrzeni dynamicznie wpływającej na tożsamości zamieszkujących je podmiotów (ludzkich i zwierzęcych), wywołującej zarówno konflikty na linii społeczeństwo-jednostka, jak i stwarzającej nowe formy więzi międzygatunkowych.

W Urban Animals Holmberg podąża właśnie za przypadkami kontrowersyjnymi, wywołującymi konflikty sąsiedzkie i społeczne. Swoją argumentację opiera przede wszystkim na samodzielnie przeprowadzonych badaniach terenowych i wywiadach etnograficznych, którym towarzyszą analizy przepisów prawnych oraz programów telewizyjnych. Przyjmuje stanowisko etnometodologiczne, interesuje ją więc przede wszystkim to, w jaki sposób badani ludzie rozumieją i zarazem wytwarzają porządek społeczny.

Część pierwsza książki, Animals in the City, bada relacje międzygatunkowe w przestrzeni miasta: rozdział drugi, Bodies on the Beach: Allowability and the Politics of Place (Ciała na plaży: dostępność i polityki przestrzeni), skupia się na walce o prawo do spuszczania psów ze smyczy na plaży w Santa Cruz w Kalifornii; rozdział trzeci, Stranger Cats: Homelessness and Ferality in the City (Obce koty: bezdomność i dzikość w mieście), stanowi pogłębioną analizę statusu kotów w szwedzkich miastach. Koty wyraźnie dominują zresztą w książce jako najbardziej popularne w Szwecji zwierzęta towarzyszące, paradoksalnie jednak mające stosunkowo niski status (co widać w analizach losu tych uznanych za „dzikie” lub „bezdomne”). Warto od razu podkreślić rzucające się w oczy polskiemu czytelnikowi różnice (wynikające między innymi z obowiązujących przepisów) losów szwedzkich i polskich zwierząt. Jak czytamy, w Szwecji problem bezdomnych psów w zasadzie nie istnieje, dopiero na przykładzie kotów Holmberg może badać interesujące ją przejawy działania - rozumianego za Michelem Foucaultem - powiązania wiedzy/władzy, kształtującego zarówno oddolnie, jak i w postaci odgórnych regulacji prawnych status zwierzęcia w mieście.

Opisywany w rozdziale drugim przypadek kalifornijskiej psiej plaży jest bardzo ciekawy ze względu na wyróżnione przez Holmberg dwa rodzaje liminalności: zarówno plaża, jak i pies sytuują się pomiędzy kulturą a naturą. Autorka bada odsłony konfliktu, skupiając się na potencjalnie wywrotowym statusie psów i ich ludzi: „kusi mnie, by interpretować psy i ich ludzi jako «transgatunkowy miejski tłum» [trans-species urban crowd], który porusza się swobodnie [...] i budzi strach u niektórych bardziej skłonnych do porządku obywateli”" We wszystkich kolejnych analizach Holmberg wskazuje właśnie na różnie realizujące się międzygatunkowe 
wspólnoty, które tyleż zagrażają porządkowi społecznemu, ile wskazują na możliwości wyjścia ku nowym modelom relacji.

Rozdział trzeci, w którym Holmberg bada reguły „za-kot-egoryzowania” (cat-egorization) kotów przebywających w przestrzeni miejskiej jako „zagubionych”, „bezdomnych” lub „dzikich”, stanowi wstęp do analiz w dalszych częściach książki. Koty definiuje zarazem ich relacja z ludźmi, jak i miejsce, w którym przebywają. Od tego, czy kot mieszka w domu, czy przypadkiem zabłąkał się na ulicy lub na stałe żyje poza jakimkolwiek domostwem, może, całkiem dosłownie, zależeć jego życie. Jednym z głównych problemów okazuje się bowiem kwestia bezdomności, która wprost wskazuje na pewien założony społeczny ideał domu. Koty dzikie lub bezdomne uosabiają obcość, która zagraża społecznemu porządkowi (w myśl obowiązujących w Szwecji przepisów koty dzikie, nierokujące nadziei na oswojenie, po wyłapaniu są usypiane). Jeśli mają szansę przeżyć, to tylko dzięki obywatelskiemu nieposłuszeństwu grup karmicieli, którzy w tajemnicy przed służbami roztaczają nad nimi opiekę. Holmberg wskazuje na alternatywny wobec dominującego modelu jeden właściciel-jeden kot (one-owner-one-cat model) model kolektywnej opieki nad zwierzętami, w którym grupa ludzi oddolnie się organizuje, by pomagać wolno żyjącym kotom.

Część druga książki, Humanimal Transgressions, każe nam bliżej przyjrzeć się dramatycznym niekiedy obliczom opieki nad zwierzętami. Holmberg zwraca uwagę przede wszystkim na zazwyczaj bezlitośnie egzekwowane przez społeczeństwo normy dotyczące przestrzeni domu oraz relacji między człowiekiem a zwierzęciem. Rozdział czwarty, Verminizing: Making Sense of Urban Animal Hoarding (Zmieniane w szkodniki: nadawanie sensu miejskiemu zbieractwu zwierzą ${ }^{9}$ ), podejmuje temat tak zwanych zbieraczy zwierząt (animal hoarders), a więc osób, przede wszystkim kobiet, dotkniętych syndromem zbieractwa, które kompulsywnie gromadzą w swoich domach zwierzęta. Badaczka skupia się na dyskursie psychologicznym oraz na narracjach popularnych telewizyjnych serii (produkowanych między innymi przez kanał Animal Planet), wskazuje na zakładany ideał prawidłowej więzi między człowiekiem a zwierzęciem, która opierałaby się na pewnym dystansie emocjonalnym, na unikaniu takiego zaangażowania uczuciowego, które może istnieć wyłącznie w kontakcie z drugim człowiekiem. Zbieraczka traci kontrolę nad swoim życiem i nad swoim domem, który w posiadanie biorą zwierzęta - brudzące, śmierdzące. Taką wizję zwierząt jako pasożytów lub szkodników Holmberg określa ciężkim do przełożenia na język polski terminem verminizing, bliskim znaczeniowo - może paradoksalnie - dehumanizacji. Zauważa, że choć wizja ta mija się z rzeczywistością - zwierzęta zbieraczy cierpią z powodu rażących zaniedbań - służy jednak regulowaniu i egzekwowaniu wizji społecznego ładu.

W rozdziale piątym, zatytułowanym Feline Feminity: Emplacing Cat Ladies (Kocia kobiecość: umiejscowienie kociar), Holmberg między innymi na podstawie telewizyjnych seriali oraz filmów dokumentalnych analizuje figurę „szalonej kociary” [crazy cat lady] lub „kociej matki” (catmother). Jest to, jak czytamy, typowe szwedzkie określenie na „kociarę"10 - a więc samotnej kobiety, która swoje życie dzieli wyłącznie z kotami. Fenomen „kociar”, co chyba nie dziwi, odczytuje nie tylko poprzez namysł nad relacjami człowiek-zwierzę, lecz także w kluczu feministycznym. Kobieta-kociara jest przede wszystkim samotna, a więc, podobnie jak zbieraczka, nie jest w stanie (lub co gorsza nie chce) nawiązać bliskich więzi z drugim człowiekiem.

Ostatnia, trzecia część, The Promises of Crowding in Zoocities, ma charakter otwartego podsumowania. Rozdział szósty, Beyond Crowd Control (Poza kontrolą tłumu), w zasadzie streszcza dotychczasową argumentację, wskazując na wagę opisywanych zjawisk, rozgrywających się gdzieś na obrzeżach życia społecznego. Holmberg pisze: „Obietnice, jakie niesie ze sobą stłoczenie w zoomiastach, leżą nie tyle w pokojowym porozumieniu, ile w potencjalnych rozdarciach i przeciekach [leakages], na które agonistyczna heterogeniczność naraża ideały hegemonicznej czystości”11. Rozdział siódmy, Open Endings (Otwarte zakończenia), jest zaś zapisem rozmowy między autorką oraz artystką Katją Aglert, autorką okładki książki, poruszającym rozpatrywane w niej problemy, często zresztą w sposób bardziej pogłębiony i wzbogacony o szersze konteksty.

Urban Animals z całą pewnością jest dziełem istotnym, poruszającym problemy, które wymagają wnikliwych i subtelnych analiz wyczulonych na kwestię zwierzęcą. Z założenia interdyscyplinarna książka może przydać się zarówno badaczom animal studies, studiów miejskich, jak i socjologom czy kulturoznawcom. Omawia tematy wydawałoby się marginalne, ale 
niezwykle ciekawe i prowokujące do dalszych analiz. Można na przykład zadać pytanie, jakim typom relacji człowiek-zwierzę sprzyja funkcjonująca choćby w Warszawie regulowana przepisami ochrona kotów wolno żyjących oraz gwarantowana pomoc dla ich karmicielek. Jakie założenia towarzyszą toczącej się w polskich miastach dyskusji o konieczności wyznaczenia osobnych psich parków?

Trzeba jednak przyznać, że całość pozostawia uczucie pewnego niedosytu. Autorka opowiada się za wartością tego, co obce, i należałoby widzieć w tym odzwierciedlenie etycznego przekonania o konieczności obrony inności przed wpływem ujednolicających i totalizujących norm. Holmberg dowartościowuje relacje i podmioty uznawane za „brudne”, „nieuporządkowane”, „chaotyczne”, „niedające się zdyscyplinować”, wskazuje na ich twórczy i więziotwórczy potencjał. Przestrzeń miasta, mimo że porządkowana (przynajmniej w założeniu) przez człowieka, okazuje się polem doświadczalnym nowych, niedających się tak łatwo regulować form ludzko-zwierzęcych więzi. Nie sposób jednak przeoczyć paradoksalnej nieobecności perspektywy zwierzęcia w dziele. Holmberg zastrzega, że celowo nie sięga do literatury etologicznej, że świadomie skupia się wyłącznie na ludzkich sposobach rozumienia i praktykowania relacji ze zwierzętami. Można to stanowisko zrozumieć; wyjaśnienia etologiczne mogą dawać iluzję zrozumienia i przekazania zwierzęcej perspektywy, która nadal wypowiadana jest w naszym, antropocentrycznym języku. Jednak wydaje się, że nieprzypadkowo Holmberg w rozdziale poświęconym „zbieraczkom” co jakiś czas podkreśla, że jej analizy, niuansujące zjawisko zbieractwa, nie mają na celu przesłonięcia problemu cierpienia zwierząt i zajmowanej przez nie pozycji ofiary. Zwierzęcy punkt widzenia jest bowiem w nich nieobecny, a w związku z tym może nawet, wbrew intencjom autorki, wydawać się nieważny.

Holmberg próbuje podważyć humanistyczne przekonanie o przyrodzonej wyjątkowości człowieka i idącą za nim wizję wyższości relacji międzyludzkich nad międzygatunkowymi. Dokonuje tego, przyglądając się uważnie tym relacjom, które łatwo zaklasyfikować jako patologiczne lub co najmniej dziwne czy niepokojące. Wykazuje, że więź ze zwierzęciem (lub wieloma zwierzętami) może być traktowana jako wartościowa sama w sobie, a nie wyłącznie jak substytut więzi z drugim człowiekiem. Problemem jednak pozostaje sytuacja zwierząt; wydaje się, że jeśli nie podejmiemy próby może nie tyle dotarcia do nich, ile uwzględnienia ich perspektywy, ryzykujemy ich uprzedmiotowienie.

Książka wzbogacona jest fotografiami miejskich zwierząt. Co ciekawe, nie są one przedmiotem analiz, pełnią wyłącznie funkcje ilustracyjne. Może to nawet wywoływać pewną irytację, sprawiają bowiem wrażenie dość przypadkowych. Przedstawiają po prostu jakieś zwierzęta w miejskich lub domowych przestrzeniach - kota siedzącego na murku, zadowolonego psa trzymającego piłkę w pysku, kociaka przechadzającego się po zatłoczonej ulicy. Można zaryzykować stwierdzenie, że fotografie te pozwalają czytelnikowi skonfrontować się z tym, czego czasem brakuje w analizach szwedzkiej badaczki, a więc z niedającą się łatwo opisać, a domagającą się zauważenia zwierzęcą innością. Jednocześnie lektura Urban Animals sprawia, że w sfotografowanych psach i kotach dostrzeżemy pełnoprawnych aktorów społecznych, uwikłanych w rozmaite ludzko-zwierzęce dramaty.

\section{PRZYPISY}

1 Tora Holmberg - socjolożka, pracuje jako wykładowczyni na Wydziale Socjologii Uniwersytetu w Uppsali. Autorka prac z zakresu socjologii miasta, animal studies, studiów nad nauką i technologią (STS) oraz kulturoznawstwa.

2 K. Thomas, Man and the Natural World. A History of Modern Sensibility, New York 1983, s. 119 (wszystkie tłumaczenia, o ile nie zaznaczono inaczej, własne JS).

3 Por. K. Weil, Thinking Animals. Why Animal Studies Now?, New York 2012, s. 56.

4 Por. D. Haraway, Manifest gatunków stowarzyszonych, przeł. J. Bednarek, w: A. Gajewska (red.), Teorie wywrotowe. Antologia przekładów, Poznań 2012

5 Zdecydowałam się na tłumaczenie terminu crowding jako "stłoczenie", alternatywą byłoby chyba bardzo podobne "zatłoczenie". Holmberg przypomina, że pierwsze eksperymenty nad konsekwencjami przebywania w zatłoczonej przestrzeni odbywały się na szczurach, którym pozwalano na niekontrolowane roz mnażanie się, a następnie badano ich zachowanie oraz umieralność. Por. tamże, s. 48. 
6 T. Holmberg, Urban Animals. Crowding in Zoocities, London-New York 2015, s. 57. Wszystkie przypisy odsyłają do wydania e-book.

7 Tamże, s. 45.

8 Tamże, s. 106-107.

9 Termin verminizing tłumaczę opisowo, a przez to w sposób na pewno nie dość satysfakcjonujący. Może dałoby się zaryzykować neologizm „werminizacja”.

10 Por. tamże, s. 233

11 Tamże, s. 275 
Sara Herczyńska

\section{Mleko, tężec i słoń Jumbo. Kanadyjskie zwierzęta miejskie}

Joanna Dean, Darcy Ingram, Christabelle Sethna ${ }^{1}$ (red.), Animal Metropolis: Histories of Human-Animal Relations in Urban Canada, Ottawa 2017, ss. 358.

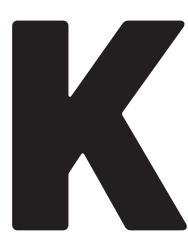

anada jest niezwykle ciekawym przykładem do analizy tematu zwierząt w mieście, czy może raczej połączenia tego, co zwierzęce, z tym, co miejskie. Redaktorki tomu Animal Metropolis: Histories of Human-Animal Relations in Urban Canada zwra-

cają uwagę na typowe wyobrażenia na temat tego kraju, związane z rozbuchaną roślinnością, majestatycznymi pejzażami i wieloma egzotycznymi gatunkami dzikich zwierząt, które jednocześnie kontrastują z wysokim poziomem zurbanizowania kraju (obecnie ponad 80 procent Kanadyjczyków mieszka w miastach). Badanie miejskich zwierząt, zwłaszcza gatunków synantropijnych, wydaje się efektywnym sposobem na mapowanie nadal pokutującego w wyobrażeniach społecznych podziału na „naturę” i „kulturę” (w ramach którego zwierzęta byłyby w pierwszej, a miasto w drugiej kategorii), a także na wydobywanie ideologii stojących za tym podziałem. W tym celu autorzy i autorki Animal Metropolis badają bardzo różne miejskie zwierzęta: domowe, dzikie, ale też zamieszkujące specjalnie dla nich przeznaczone przestrzenie, takie jak cyrki, akwaria i ogrody zoologiczne.

Książka Animal Metropolis została wydana w cyklu Canadian History and Environment poświęconym historii środowiskowej, w ramach którego wcześniej ukazały się publikacje o między innymi kanadyjskich parkach, górnictwie i ekologicznych aspektach kontrkultury. I znowu Kanada stanowi fascynujący obiekt badań dla specjalistów od historii środowiskowej. Już sama wizja tego kraju jako rezerwuaru „dziewiczej przyrody” jest silnie związana z historią tego regionu i towarzyszącymi jej narracjami politycznymi. Jak zauważają redaktorki Animal Metropolis, jej korzenie tkwią w rasistowskich wyobrażeniach o Ameryce Północnej jako terra nullius - dziewiczej ziemi niczyjej². Rdzenni mieszkańcy tego kontynentu należą w tej wizji do sfery natury, zredukowani do roli dzikiego lub zwierzęcia.

Na publikację Animal Metropolis składa się dziesięć esejów, uporządkowanych mniej więcej chronologicznie, różniących się od siebie tematyką i podejściem badawczym. Spięte są one łączącym je wstępem oraz epilogiem. Autorzy i autorki zajmują się miejscami, w których przecinają się historie zwierząt (jednostek i gatunków) z historiami kanadyjskich miast. Z poszczególnych rozdziałów wyłania się wytworzona przez nich wizja rozwoju miast, który był współtworzony przez ludzi i zwierzęta (albo, jak konsekwentnie piszą autorki oraz autorzy zgromadzonych w tomie esejów, „ludzkie i nie-ludzkie zwierzęta”). Zwierzęta współtworzyły i podtrzymywały życie miast, czasem będąc dostarczycielem niezbędnych surowców, a czasem źródłem rozrywki. 
Miasto jako hybryda ludzko-zwierzęca szczególnie uwidacznia się w perspektywie historycznej, w świetle czasów końskich tramwajów i miejskich hodowli. Eseje zgromadzone w Animal Metropolis dotykają tych kwestii poprzez badanie konkretnych przypadków, takich jak historia bobrów w Stanley Park w Vancouver albo wystawy ryb tworzone przez Samuela Wilmota. Publikacja dotyczy zarówno prawdziwych zwierząt, jak i ich obrazów (które wbrew Bergerowskiemu podejściu ${ }^{3}$ nie są traktowane jak puste symulakrum).

Część autorek zebranych w książce esejów stosuje podejście intersekcjonalne, zderzając badania z historii środowiskowej lub animal studies z pojęciami kluczowymi dla teorii krytycznej, takimi jak rasa czy płeć. Do nich należy Christabelle Sethna, która w tekście The Memory of an Elephant: Savagery, Civilization, and Spectacle przytacza historię afrykańskiego słonia Jumbo wzoru dla słynnego Dumbo - a także źródła angielskiego słowa jumbo oznaczającego „wielki”4. Jumbo urodził się około 1860 roku w Sudanie. Został schwytany i przewieziony do Europy, przez pewien czas był wystawiany jako okaz w Jardin des Plantes, potem w londyńskim zoo, aż w końcu został wywieziony do Ameryki Północnej. Zginął w wypadku kolejowym w kanadyjskim mieście St. Thomas w prowincji On-

W ramach założeń przyjmowanych przez autorów i autorki esejów zwierzęta faktycznie sq aktywnymi czynnikami pozaludzkimi, jednak $w$ podobny sposób, jak są nimi wspomniane wyżej laseczki tężca. tario. Sethna analizuje hi-

storię Jumbo w kontekście europejskiego i amerykańskiego rasizmu: z jednej strony czarni niewolnicy byli traktowani jak zwierzęta, z drugiej zwierzęta były traktowane jak niewolnicy. Autorka pokazuje, jak na ciało słonia nakładano wyobrażenia o czarności i jak jego afrykańskie pochodzenie wpływało na reakcje widzów. Związki zwierzęcia z historią miast opierają się z jednej strony na miejskim charakterze cyrku, a z drugiej na funkcjonowaniu Jumbo jako atrakcji turystycznej miasta St. Thomas. Został on upamiętniony przez wielki pomnik (w roli atrakcji przydrożnej), a mieszkańcy długo żywili nadzieję, że dzięki promocji „na słonia” St. Thomas rozkwitnie ekonomicznie.

Inną autorką, która korzysta z zaplecza teorii krytycznej, jest Carla Hustak, która w rozdziale Got Milk? Dirty Cows, Unfit Mothers, and Infant Mortality, 1880-1940 pisze o krowim mleku w kontekście rasy, kobiecości i macierzyństwa 5 . Przywołuje feministyczne dyskusje dotyczące kwestii karmienia piersią. Tu również pojawia się aspekt kolonialny, na przykład w przypadku skandalu wokół firmy Nestlé, której kampania promująca preparaty do żywienia początkowego w Indiach i w niektórych krajach afrykańskich doprowadziła do chorób i śmierci wielu niemowląt (głównie ze względu na niedostosowanie produktu do lokalnych warunków sanitarnych). Na przykładzie miasta Hamilton w prowincji Ontario Hustak bada warunki funkcjonowania krów na terenach miejskich oraz towarzyszące im obawy dotyczące kwestii sanitarnych i zdrowia publicznego. Interesuje ją też wpływ tych zwierząt na praktyki związane z macierzyństwem (zwłaszcza na dyskurs wokół karmienia piersią) w procesie „unaukawiania” opieki nad dziećmi. Jednocześnie zwraca ona uwagę na historyczne i aktualne analogie w mechanizmach zarządzania ciałami kobiet oraz krów.

Te dwa przykłady pokazują rozmach, a także różnorodność metodologii przyjętych przez autorki i autorów. Animal Metropolis to książka świetnie napisana i dotycząca ważnych tematów, do tego zilustrowana niezwykle ciekawym materiałem wizualnym. Każdy z dziesięciu esejów może być czytany jako oddzielny tekst, a razem składają się na zróżnicowaną opowieść o historii Kanady. Należy też docenić różnorodność teorii zastosowanych w analizach i ich trafne dobranie do konkretnych przypadków: teoria feministyczna i krowie mleko, teoria postkolonialna i słoń Jumbo, teoria asamblaży i laseczki tężca... Wychodząc poza kwestie merytoryczne, na uznanie zasługuje też dostępność publikacji. Animal Metropolis 
to książka dostępna do pobrania za darmo w formacie PDF na stronie wydawnictwa University of Calgary Press ${ }^{6}$.

Pewne wątpliwości może jednak budzić ochocze przypisywanie zwierzętom przez redaktorki podmiotowego statusu i zapewnianie o ich roli we współtworzeniu miasta, wynikające z przyjętych przez autorów i autorki teorii. Jak pisze w epilogu książki Sean Kheraj: „Zwierzęta aktywnie powodowały zmiany, a ich zachowania pobudzały i wymuszały różne ludzkie reakcje. W rzeczywistości ludzie i zwierzęta wspólnie rozwinęli miasta jako hybrydyczne ludzko-zwierzęce środowiska”. W podobne tony wpadają redaktorki tomu we wstępie: „[...] rozszerzenie sprawczości na inne gatunki [...] może mieć reperkusje dla pisania historii, jak wtedy, kiedy ludzie tracą centralną pozycję, gdy wieloryby kształtują nasze działania lub gdy pożerają nas wilki i lwy, zamiast my je"8. Jednocześnie z zebranych esejów wyłania się obraz zwierząt wyzyskiwanych przez ludzi, traktowanych przedmiotowo, bitych i pozbawionych możliwości swobodnego działania. Trudno znaleźć przykład, który świadczyłby o skuteczności autonomicznie podejmowanych zwierzęcych działań. Czy zatem podkreślanie aktywnej roli zwierząt w tworzeniu miasta nie jest przesadzone? W ramach założeń przyjmowanych przez autorów i autorki esejów zwierzęta faktycznie są aktywnymi czynnikami pozaludzkimi, jednak w podobny sposób, jak są nimi wspomniane wyżej laseczki tężca. Redaktorki tomu miejscami przekraczają granicę między konsekwentnym trzymaniem się teorii posthumanistycznych a antropomorfizacją zwierząt. Problem jednak tkwi w scalających tom wstępie i epilogu, a nie w głównych dziesięciu esejach, w których w trafny sposób omówiono konkretne przypadki.

\section{PRZYPISY}

1 Kanadyjskie badaczki związane z takimi uczelniami jak Carleton University, Selkirk College oraz University of Ottawa. Joanna Dean specjalizuje się głównie w historii środowiskowej i historii zwierząt, Darcy Ingram zajmuje się historią oraz socjologią w kontekście ekologicznym, a Christabelle Sethna historią seksualności czy studiami postkolonialnymi.

2 D. Ingram, C. Sethna, J. Dean, Introduction: Canamalia Urbanis, w: też same (red.), Animal Metropolis: Histories of Human-Animal Relations in Urban Canada, Ottawa 2017, s. 10-11.

3 J. Berger, Po cóż patrzeć na zwierzęta?, w: tenże, O patrzeniu, przeł. S. Sikora, Warszawa 2005.

4 C. Sethna, The Memory of an Elephant: Savagery, Civilization, and Spectacle, w: D. Ingram, C. Sethna, J. Dean (red.), Animal Metropolis..., dz. cyt., s. 29-56.

5 C. Hustak, Got Milk? Dirty Cows, Unfit Mothers, and Infant Mortality, 1880-1940, w: D. Ingram, C. Sethna, J. Dean (red.), Animal Metropolis..., dz. cyt., s. 189-218.

6 https://press.ucalgary.ca/books/9781552388648 (dostęp: 10.11.2019).

7 S. Kheraj, Epilogue: Why Animals Matter in Urban History, or Why Cities Matter in Animal History, w: D. Ingram, C. Sethna, J. Dean (red.), Animal Metropolis..., dz. cyt., s. 314

8 D. Ingram, C. Sethna, J. Dean, Introduction: Canamalia Urbanis, dz. cyt., s. 8. 
Zofia Jakubowicz-Prokop

\section{Polityki nie-ludzkiego miasta. The City Is More Than Human Fredericka L. Browna}

Frederick L. Brown ${ }^{1}$, The City Is More Than Human. An Animal History of Seattle, Seattle-London 2016, ss. 331.

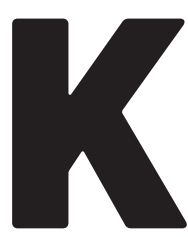

siążka Fredericka L. Browna The City Is More Than Human jest pracą o historii Seattle, będącej zarazem historią stopniowego wypierania zwierząt poza granice miasta $\mathrm{w}$ imię idei nowoczesności i postępu. Brown opowiada o Seattle, od przybycia pierwszych białych osadników nad zatokę Puget na początku XIX wieku aż po czasy współczes$n^{2}$. Chociaż dzieje miasta, przynajmniej na pierwszy rzut oka, są historią ekspansji i dominacji białych euroamerykańskich (ludzkich) osadników oraz ich potomków, Brownowi dzięki wnikliwej analizie ogromnej liczby źródeł historycznych udaje się wydobyć spod dominującej narracji jej wielopoziomową złożoność. Przede wszystkim koncentruje się on na ukazaniu roli, jaką w powstawaniu i kształtowaniu się miasta odegrały zwierzęta, od samego początku pokazuje jednak, że ich historia nie daje się oddzielić od historii konfliktów rasowych, klasowych czy genderowych. Nie oznacza to bynajmniej, że zwierzęta po raz kolejny okazują się jedynie pretekstem do opowiedzenia o czym innym - wręcz przeciwnie, przemyślana narracja książki ukazuje, jak losy pojedynczych ludzi oraz całych społeczności są nierozerwalnie splecione z działaniami nie-ludzkich aktorów i od nich zależne.

Główną tezą Browna jest to, że konstruowanie przestrzeni miejskiej opiera się w dużej mierze na wyznaczaniu granic pomiędzy tym, co „ludzkie” i „zwierzęce” oraz, co za tym idzie, „cywilizowane” i „dzikie”. Tożsamość miasta jako przestrzeni nowoczesnej i postępowej budowana jest poprzez wykluczanie tego, co z bieżącym wyobrażeniem nowoczesności i postępu stoi w sprzeczności. Jednocześnie - co badacz nieustannie podkreśla - kategoryzowanie oraz dzielenie miasta i jego mieszkańców [sorting] zawsze pociąga za sobą przekraczanie, a także zacieranie wyznaczanych granic [blending] $]^{3}$. Jak zauważa we wstępie:

Dekady ustalania, gdzie które zwierzęta przynależały w mieście, za pomocą środków zarówno prawnych, jak i społecznych, nie zmieniły faktu, że Seattle jest miastem wymieszanym [blended] - miejscem, w którym zwierzęta pozostają niedoskonale posortowane, ponieważ ludzie nie są ze sobą zgodni w kwestii kategorii i zasad, jakie na nie nakładają, i ponieważ zwierzęta często chodzą tam, gdzie chcą, niezależnie od ludzkich wyobrażeń4. 
Wizje nowoczesnego miasta i panujących w nim stosunków zmieniały się w czasie zależnie od aktualnych warunków środowiskowych, ekonomicznych, politycznych i społecznych, silnie wpływając na status i kulturowe znaczenie zwierząt. Autor dowodzi, że kształtowanie przestrzeni miejskiej skorelowane było z pozycją zajmowaną przez poszczególne gatunki zwierząt, ta z kolei wynikała z takich rozróżnień, jak „udomowione-dzikie”, „własne-niczyje”, „przydatne-nieprzydatne”, „o wartości użytkowej” i „o wartości sentymentalnej”.

Niezwykle ciekawa pod tym względem jest opisywana przez Browna historia bydła w Seattle. Pierwsze zwierzęta gospodarskie pojawiły się nad Elliot Bay w nowo założonej osadzie, przekształconej wkrótce w miasto Seattle, na początku lat 50. XIX wieku. Bydło - jak podkreśla autor - podobnie jak ideały ludzko-zwierzęcych stosunków opartych na jasnym podziale oraz dominacji jednych nad drugimi, zostało przywiezione przez osadników z Europy i miało odegrać zasadniczą rolę kolonizacyjną. Posiadanie zwierząt hodowlanych, będących źródłem pożywienia i pomocą przy uprawie ziemi, oznaczało efektywniejszą ekspansję, a także szybsze gromadzenie dóbr; z kolei na poziomie symbolicznym w oczach białych osadników stanowiło dowód na wyższość europejskiej kultury wobec kultur autochtonicznych. Hodowanie zwierząt, władza nad przyrodą i zaprzęgnięcie jej do realizacji ludzkich celów wyznaczało granicę między cywilizacją a tym, co dzikie. Jednocześnie, jak podkreśla Brown, zwierzęta te bynajmniej nie były tak podporządkowane, jak tego od nich oczekiwano. Krowy oraz woły chodziły wolno po okolicznych terenach, wymykały się spod kontroli i dziczały ${ }^{5}$. To z kolei skłaniało osadników do budowania ogrodzeń, które z jednej strony miały służyć kontrolowaniu zwierząt, z drugiej natomiast stawały się sposobem na zawłaszczanie ziemi. Niektórzy Saliszowie pomagali osadnikom w budowaniu płotów, chlewów i obór, inni jednak, w aktach protestu przeciwko ekspansji nowo przybyłych, dokonywali zamachów na ich własność, atakując i zabijając hodowane zwierzęta.

Hodowanie krów, owiec i koni na nowych, niezagospodarowanych dotąd przez osadników ziemiach oznaczało co innego niż na Starym Kontynencie. Odmienne okoliczności wymagały od nich rewidowania zakorzenionych w europejskiej kulturze przekonań i adaptacji do nowych warunków. Chodziło z jednej strony o warunki środowiskowe, o zachowania zwierząt dzikich i udomowionych, z drugiej natomiast o reakcje i działania autochtonicznych społeczności, z którymi nowi osadnicy musieli nawiązywać różnorodne relacje. Dlatego każda działalność kolonizacyjna, każdy etap budowania miasta, choć związane z przemocą i wykluczeniem, w jakiejś mierze wymagały kompromisów oraz wzajemnego dostosowywania się wszystkich podmiotów, które były w jakiś sposób w nie włączone. Oczywiście kompromisy te zależały ostatecznie od bieżących relacji władzy, Brown jednak nieustannie przypomina, że opór stawiany kolonizatorom, nawet jeśli nie do końca skuteczny, odgrywał istotną rolę w kształtowaniu się miasta.

Jak pokazuje historyk, początkowa rozbudowa Seattle była ściśle związana z ludzko-nieludzkimi relacjami w tym sensie, że stanowiła sposób zarządzania zwierzętami. Kształt miasta wynikał jednak również z tego, że osadnicy, których los często zależał od dobrostanu zwierząt gospodarskich, żyli z nimi, dbali o nie i - o czym świadczą między innymi przytaczane przez badacza fragmenty listów oraz dzienników - obdarzali je uczuciami. Jednak bydło, świnie, konie i inne zwierzęta zaprzęgane przez osadników do pracy, których posiadanie długo świadczyło o majątkowym i społecznym statusie, w miarę rozwoju miasta stawały się coraz większym obciążeniem dla dominującej białej klasy średniej. Z symbolu cywilizacji i nowoczesności zaczęły przekształcać się w symbol biedy i zacofania, przez co ich obecność w mieście stała się niepożądana. Zwierzęta zaczęto klasyfikować zgodnie z nowym podziałem - na te, które przedstawiają dla ludzi wartość użytkową, i te, z którymi ludzie nawiązują relacje emocjonalne i „bezinteresowne”. Życie krów i świń, przypisanych do pierwszej kategorii, zostało przeniesione poza miasto i podporządkowane wielopoziomowym systemom masowej produkcji.

Opowieść Browna jest historią o narastającej kontroli i nasilającej się potrzebie kategoryzacji, które szły w parze z bieżącą wizją nowoczesności i miejskiego postępu. Najlepiej widać to na przykładzie takich zwierząt jak krowy, owce czy świnie, jednak w The City Is More Than Human jest ich znacznie więcej. Pojawiają się tu kuguary, bobry oraz łososie, których obecność była szczególnie istotna dla euroamerykańskich osadników we wczesnej fazie kolonizacji zatoki Puget. Dzikie zwierzęta stanowiły dla nich realne zagrożenie lub źródło dochodu (pierwsze osadnictwo w zatoce związane było z polowaniami na bobry i futrzarstwem), ale były też ważnymi aktorami w spotkaniach nowo przybyłych i autochtonicznych społeczności. Są tu również 
koty i psy, które długo uznawano za zwierzęta pracujące - jako zaganiacze bydła, ochroniarze, opiekunowie dzieci - które jednak z czasem, częściowo ze względu na tę ostatnią funkcję, zaczęły pełnić przede wszystkim rolę zwierząt towarzyszących. To z kolei wiązało się z narastającą kontrolą ich populacji i podporządkowywaniem ich sposobu życia wizji nowoczesnego miasta, co dobrze pokazują opisywane przez badacza debaty dotyczące smyczy w latach 30. i 50. XX wieku. Najczęściej pojawiające się argumenty za wprowadzeniem obowiązku prowadzenia psów na smyczach były związane z poczuciem zagrożenia, jakie swobodnie poruszające się po mieście zwierzęta stanowiły dla ludzi, miejskiego porządku i własności prywatnej ${ }^{6}$.

Brown wskazuje na trzy podziały, które odegrały kluczową rolę w kształtowaniu się przestrzeni miejskiej w historii Seattle i wiązały się ze zmieniającą się w niej rolą zwierząt: podział na ludzi oraz zwierzęta, na to, co oswojone, i to, co dzikie, oraz na zwierzęta towarzyszące i żywy inwentarz. Autor uzmysławia także, że zwierzęta, same poddawane w obrębie miasta segregacji, były jednocześnie wykorzystywane $\mathrm{w}$ ustanawianiu innych podziałów. Los poszczególnych gatunków nieustannie przeplatał się ze społecznymi konfliktami: wyznaczanie zwierzętom odpowiednich przestrzeni, ale też nadawanie im znaczeń symbolicznych przeważnie wiązało się z ustalaniem społecz-

Los poszczególnych gatunków nieustannie przeplatał się ze społecznymi konfliktami: wyznaczanie zwierzętom odpowiednich przestrzeni, ale też nadawanie im znaczeń symbolicznych przeważnie wiq̨zało się z ustalaniem społecznej hierarchii w mieście czy rozgrywaniem klasowych i rasowych sporów. nej hierarchii w mieście czy rozgrywaniem klasowych i rasowych sporów. Strategie oparte na segregacji oraz porządkowaniu przeważnie stosowane były przez dominujące grupy społeczne, które wykorzystywały swoją władzę, by organizować życie zwierząt w obrębie miasta, co często silnie wpływało na życie związanych z nimi ludzi. Przykładowo, wspierany przez białą klasę średnią zakaz posiadania w mieście zwierząt gospodarskich istotnie obniżył status ludzi, którzy utrzymywali się z ich hodowli. Z drugiej strony strategie związane z przekraczaniem narzuconych podziałów czy mieszaniem kategorii często wykorzystywane były przez grupy o słabszej pozycji społecznej Brown wymienia dzieci, kobiety, klasę robotniczą, mniejszości rasowe i imigrantów. Tu przykładem może być większe zaangażowanie we wczesne ruchy na rzecz praw zwierząt kobiet, dla których przez jakiś czas stanowiło to jedyną dostępną aktywność polityczną.

Zarazem Brown pokazuje, że gdy upraszczająca narracja o ludzko-zwierzęcych podziałach w dużej mierze (choć nie tylko) była strategią uprzywilejowanych mieszkańców, praktyki mniejszości często sprzyjały mieszaniu i przekraczaniu wytyczanych przez elity granic - czego najprostszym przykładem mogą być feminizujące się przez lata ruchy prozwierzęce. Jednocześnie kategorie klasowe czy genderowe były często przenoszone z relacji między ludźmi na zwierzęta, co skutkowało między innymi przekonaniem, że ograniczanie psiej i kociej populacji najlepiej egzekwować poprzez kontrolę seksualności samic albo - by wskazać bardziej pozytywny przykład - przez traktowanie zwierząt domowych jak ludzkich dzieci.

Brownowi udaje się z powodzeniem stworzyć w książce niezwykle złożony i zróżnicowany obraz miasta, w dużej mierze dzięki uważnym oraz imponującym rozmachem badaniom źródeł historycznych. W przywoływanej przez siebie lokalnej historii pokazuje, jak istotne jest w przemyśliwaniu ludzko-zwierzęcych relacji i współzależności rozpatrywanie konkretnych przypadków, doświadczeń, interakcji i działań, często podważających upraszczające, totalizujące wizje rzeczywistości. Wyraża to zresztą strategia badawcza autora, który decyduje się pozostać blisko 
historycznych dokumentów i ostrożnie je analizować, bez wyciągania pochopnych czy uogólniających wniosków na temat miasta jako takiego. Efektem jest praca o dość ograniczonym aparacie teoretycznym (chociaż z pokaźną bibliografią), co nie jest jednak jej wadą. Dzięki temu Brown unika nadinterpretacji, nie uniwersalizuje swoich konkluzji i przynajmniej na tyle, na ile to możliwe, dopuszcza do głosu ludzkie i nie-ludzkie mieszkanki oraz mieszkańców Seattle.

Bez wątpienia jednak książka Browna ukazuje także bardziej ogólne mechanizmy. Na przykładzie Seattle widać dobrze tendencje dynamicznie rozwijającego się kapitalistycznego społeczeństwa, które konstruuje się i przekształca poprzez coraz bardziej złożone systemy segregacji, produkcji i władzy. Z pewnością, jak z - nieco monotonnym - uporem powtarza Brown, tworzenie granic w obrębie miasta zawsze pociąga za sobą różnorodne strategie ich przekraczania, jednak w miarę jego rozrastania się panujące między jego mieszkankami i mieszkańcami relacje oraz podziały stają się coraz bardziej złożone i niejasne. Autor pozostaje wyczulony na te komplikacje, a jego zdolność do ich wychwytywania i relacjonowania bez popadania w redukcjonizm imponuje. Nieco zbyt ogólny charakter głównej, powtarzanej wielokrotnie tezy, że strategie oparte na segregacji i stawianiu granic są zawsze sprzężone ze strategiami opartymi na podważaniu podziałów i zacieraniu różnic, może jednak pozostawiać niedosyt.

\section{PRZYPISY}

1 Książka powstała na podstawie pracy doktorskiej, którą Frederick L. Brown obronił na Uniwersytecie Waszyngtońskim w 2010 roku. Autor związany jest z National Park Service, instytucją zarządzającą parkami narodowymi w Stanach Zjednoczonych, dla której jako historyk prowadził badania m.in. nad pomnikiem narodowym Lava Beds, poświęcając mu swoją pierwszą większą publikację The Center of the World, The Edge of the World: A History of Lava Beds National Monument, Seatle 2011. Współprowadził także badania historyczne i kulturowe nad Rezerwatem Narodowym Mojave, Parkiem Narodowym Canyon Kings, Parkiem Narodowym Redwoods i innymi.

2 Obszary położone pomiędzy zatoką Puget a jeziorem Washington, gdzie znajduje się obecnie Seattle, zamieszkane pierwotnie przez plemiona Saliszów, zaczęły przyciągać osadników z południa i z Europy na początku XIX wieku. Zatokę ogłoszono częścią Stanów Zjednoczonych w 1846 roku, natomiast miasto Seattle założono oficjalnie parę lat później. Początkowo utrzymywało się ono z przemysłu drzewnego, na przełomie XIX i XX wieku stało się istotnym portem handlowym, dziś natomiast jest największym i jednym z najprężniej rozwijających się miast w tej części Stanów Zjednoczonych.

3 Teza ta skądinąd w dużej mierze przywodzi na myśl koncepcję Brunona Latoura, który zostaje jednak wspomniany przez Browna zaledwie w jednym przypisie.

4 F.L. Brown, The City Is More Than Human. An Animal History of Seattle, Seattle-London 2016, s. 6 (tłumaczenie własne).

5 Brown pisze wręcz: "Stawały się dzikie jak jelenie. Trzeba było raczej na nie polować, niż je paść", tamże, s. 23.

6 Zob. tamże, s. 170-180 
Prof. Peter Atkins - emerytowany profesor geografii na Durham University. Zajmuje się historią zwierząt w miastach oraz geografią żywności w perspektywie historycznej. Redaktor tomu zbiorowego Animal Cities. Beastly Urban Histories (2012) oraz wielu artykułów i monografii, m.in. Liquid Materialities: A History of Milk, Science and the Law (2010).

Michalina Augusiak - studentka historii, kulturoznawstwa i filozofii w Kolegium Międzyobszarowych Studiów Humanistycznych i Społecznych Uniwersytetu Warszawskiego. Zajmuje się historią płci oraz seksualności, ruchów kobiecych, a także wiedzy eksperckiej i nauki w Europie Wschodniej. W Instytucie Historycznym Uniwersytetu Warszawskiego przygotowuje pracę magisterską o historiografii kobiet i polityce pamięci organizacji kobiecych w Polsce Ludowej.

Mgr Joanna Gellner - absolwentka historii i archeologii Uniwersytetu Jagiellońskiego, adiunkt w Dziale Fotografii Krakowskiej Muzeum Krakowa; współkurator wystawy czasowej Jak pies z kotem (2016). Tematyką historii zwierząt i ich obecności w życiu człowieka zainteresowana od kilku lat, obecnie szczególnie historią opieki nad zwierzętami w Krakowie.

Mgr Sara Herczyńska - doktorantka w Instytucie Kultury Polskiej Uniwersytetu Warszawskiego. Publikowała w „Przeglądzie Humanistycznym” i w tematycznych monografiach naukowych. Członkini redakcji „małej kultury współczesnej” oraz polskiej redakcji „Globalnego Dialogu” wydawanego przez Międzynarodowe Stowarzyszenie Socjologiczne (ISA). Obecnie przygotowuje pracę doktorską na temat polskich muzeów biograficznych.

Mgr Zofia Jakubowicz-Prokop - doktorantka w Międzydziedzinowej Szkole Doktorskiej Uniwersytetu Warszawskiego. Obroniła pracę magisterską poświęconą opowiadaniom o zwierzętach Zofii Nałkowskiej w Instytucie Kultury Polskiej. Publikowała m.in. w „Tekstach Drugich”, „Res Publice Nowej” i „małej kulturze współczesnej”.

Mgr Anna Jaroszuk - doktorantka w Instytucie Kultury Polskiej Uniwersytetu Warszawskiego. Publikowała m.in. w „Przeglądzie Humanistycznym”, „Adeptusie” i „Almanachu Historycznym". Prowadziła m.in. badania dotyczące obecności zwierząt oraz relacji ludzko-zwierzęcych w przestrzeni Warszawy przełomu XIX i XX wieku.

Dr hab. Igor Piotrowski - adiunkt w Zakładzie Historii Kultury Instytutu Kultury Polskiej Uniwersytetu Warszawskiego, członek i (od 2017 roku) kierownik Pracowni Studiów Miejskich działającej w Instytucie Kultury Polskiej. Zajmuje się historią kultury polskiej od czasów dawnych do współczesnych, kulturowymi reprezentacjami przestrzeni, długim trwaniem wątków i instytucji. Artykuły poświęcone relacjom biografii oraz twórczości pisarzy ostatnich dwustu lat z Warszawą publikował m.in. w „Tekstach Drugich”, „Kulturze Popularnej”, „Białostockich Studiach Literaturoznawczych” czy tomach z serii Topo-Grafie.

Dr Justyna Schollenberger - kulturoznawczyni i filozofka; zatrudniona w Instytucie Kultury Polskiej Uniwersytetu Warszawskiego. Zajmuje się przede wszystkim zagadnieniem relacji człowiek-zwierzę w kontekście namysłu posthumanistycznego. Autorka rozprawy o konceptualizacji granicy między człowiekiem a zwierzęciem w dziełach Karola Darwina, nagrodzonej I miejscem w VII edycji konkursu im. Inki Brodzkiej-Wald. Publikowała m.in. w „Tekstach Drugich”, „Przeglądzie Humanistycznym”, „Kulturze Popularnej”, „Zoophilologica. Polish Journal of Animals Studies" i innych. 
Dr Stephanie Weismann - absolwentka komparatystyki, germanistyki i rusycystyki. Studiowała na uniwersytetach w Wiedniu i Sankt Petersburgu. Ukończyła kolegium doktoranckie Austriacka Galicja i jej multikulturowe dziedzictwo na uniwersytecie w Wiedniu i obroniła rozprawę doktorską pod tytułem Das Potenzial der Peripherie. Leopold von Sacher-Masoch (1836-1895) und Galizien (opublikowaną w 2017 roku). Obecnie pracuje nad historią olfaktoryczną Lublina (historia Polski XX wieku przez pryzmat zapachów na przykładzie Lublina). Interesuje się historią zmysłową oraz historią codzienności Europy Środkowo-Wschodniej oraz Rosji w XIX i XX wieku, a także historią emocji oraz kulturą popularną komunizmu i transformacji.

Dr hab. Justyna Włodarczyk - amerykanistka, pracuje w Instytucie Anglistyki Uniwersytetu Warszawskiego, absolwentka Międzywydziałowych Indywidualnych Studiów Humanistycznych na Uniwersytecie Warszawskim i Ośrodka Studiów Amerykańskich Uniwersytetu Warszawskiego. W ramach stypendiów oraz grantów prowadziła badania na różnych uniwersytetach w USA (Indiana University, University of Illinois at Urbana-Champaign, Wesleyan University, Harvard University). Interesuje się konceptualizacją zmian w relacji ludzie-zwierzęta (zwłaszcza, choć nie wyłącznie, ludzie-psy) w kontekście szerszych zmian społeczno-kulturowych. Fascynują ją również technologie wykorzystywane do kształtowania życia zwierząt (od biotechnologii do szkolenia psów) oraz wyobrażenia zwierząt jako „technologii” (od gołębi pocztowych do psów asystujących). Autorka książki Genealogy of Obedience: Reading North American Dog Training Literature, 1850s-2000s (2018) oraz redaktorka i współredaktorka licznych pozycji z zakresu animal studies i posthumanizmu (np. wraz z Michałem Pręgowskim Free-Market Dogs: The Human-Canine Bond in Post-Communist Poland, 2016).

Prof. Jennifer Wolch - dyrektorka College of Environmental Design na University of California (Berkeley). Jedna z pierwszych badaczek zajmujących się relacjami ludzko-zwierzęcymi w przestrzeni miejskiej - autorka propozycji koegzystowania ludzi i zwierząt w miastach. Badała również miejską bezdomność; obecnie interesuje się przede wszystkim zdrowiem publicznym w perspektywie planowania miast. Opublikowała ponad sto artykułów w czasopismach, autorka monografii oraz redaktorka tomów zbiorowych, m.in. Animal Geographies: Place, Politics and Identity in the Nature/Culture Borderlands (1998).

Dr hab. Aleksander Wójtowicz - historyk literatury, edytor, adiunkt w Zakładzie Literatury XX i XXI Wieku Instytutu Filologii Polskiej na Uniwersytecie Marii Curie-Skłodowskiej. Zajmuje się dziejami europejskich ruchów awangardowych, współczesną sztuką eksperymentalną oraz edytorstwem literatury XX wieku. Autor książek Cogito i „sejsmograf podświadomości”. Proza Pierwszej Awangardy (2010) oraz Nowa Sztuka. Poczq̨tki (i końce) (2017); współredaktor monografii, edycji krytycznych i popularnych. Publikował m.in. w „Pamiętniku Literackim”, „Ruchu Literackim”, „Przeglądzie Humanistycznym”, „Kwartalniku Filmowym”.

Mgr Karolina Wróbel-Bardzik - doktorantka w Zakładzie Historii Kultury Instytutu Kultury Polskiej Uniwersytetu Warszawskiego, członkini Zespołu Badań Pamięci o Zagładzie oraz Sztuk Społecznych w IKP UW. Kieruje projektem badawczym Preludium „Historia środowiskowa okupowanej i powojennej Warszawy (1939-1947)" przyznanym przez Narodowe Centrum Nauki.

Dr Monika Żółkoś - adiunktka w Zakładzie Teorii Literatury i Krytyki artystycznej Instytutu Filologii Polskiej Uniwersytetu Gdańskiego. Autorka artykułów poświęconych humanistyce postantropocentrycznej oraz problematyce genderowej, w szczególności feministycznej historii polskiego teatru (członkini zespołu HyPaTia). Publikuje w „Didaskaliach”, „Dialogu” oraz książkach zbiorowych. 



\section{Redaktorzy naukowi}

Anna Jaroszuk

Igor Piotrowski

Karolina Wróbel-Bardzik

\section{Recenzent}

Prof. dr hab. Piotr Krupiński

\section{Redaktor prowadząca}

Katarzyna Bielawska-Drzewek

\section{Redakcja}

Jerzy Lewiński

\section{Korekta}

Klaudia Kulmińska

Publikacja współfinansowana ze środków Dziekana Wydziału Polonistyki oraz Instytutu Kultury Polskiej UW

Publikacja współfinansowana ze środków Fundacji Uniwersytetu Warszawskiego
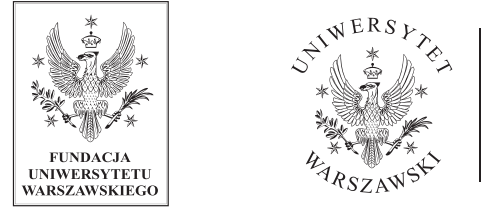

INSTYTUT

KULTURY

POLSKIEJ

(c) Copyright by Wydawnictwa Uniwersytetu Warszawskiego, Warszawa 2021

Anna Jaroszuk ORCID 0000-0001-7496-1099

Igor Piotrowski ORCID 0000-0001-6130-652X

Karolina Wróbel-Bardzik ORCID 0000-0002-6395-9118

ISBN 978-83-235-4872-0 (druk)

ISBN 978-83-235-4880-5 (pdf online)

ISBN 978-83-235-4888-1 (e-pub)

ISBN 978-83-235-4896-6 (mobi)

Wydawnictwa Uniwersytetu Warszawskiego

00-838 Warszawa, ul. Prosta 69

e-mail:wuw@uw.edu.pl

księgarnia internetowa: www.wuw.pl

Wydanie 1, Warszawa 2021

\section{Projekt graficzny, projekt okładki i skład}

\section{R RZECZYOBRAZKOWE}

Uprzejmie dziękujemy Muzeum Historii Krakowa za udostępnienie fotografii. 



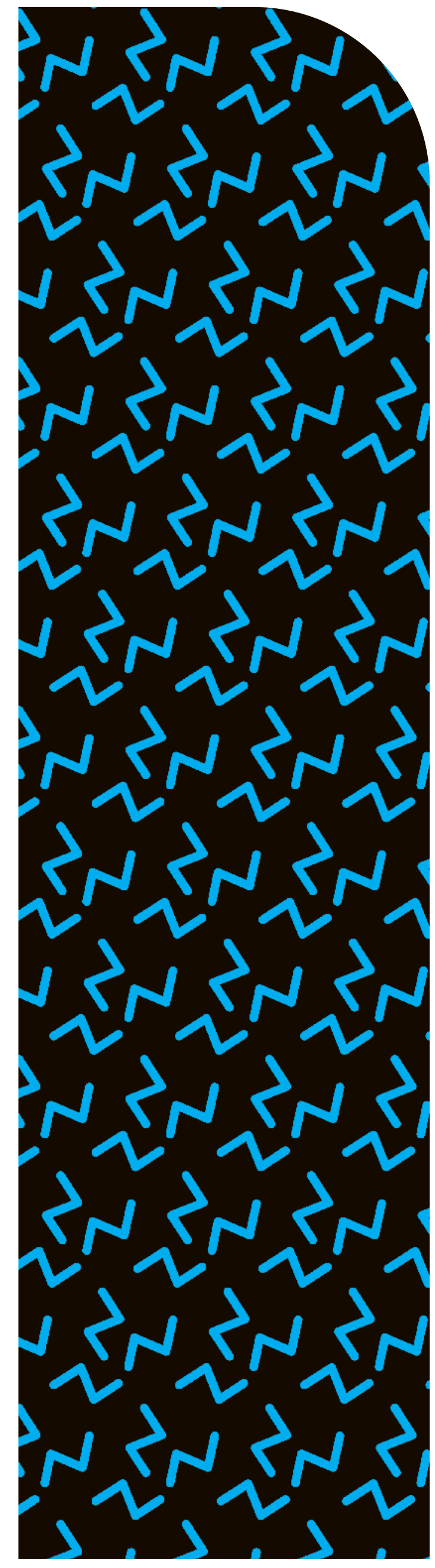

Mimo nieuniknionej heterogeniczności zagadnień, podejmowanych przez autorów tomu, zgromadzone teksty nie przypominaja swobodnej mozaiki poszczególnych case studies, ale układają się w nader spójna całość.

Gwarancją tej koherencji jest wspólne dla przyjętej przez autorów perspektywy nałożenie na siebie dwóch krajobrazów, dowodne wykazanie, że krajobraz miejski powinien być w większym niż dotąd zakresie krajobrazem moralnym, obejmującym całość ludzko-zwierzęco-roślinnej wspólnoty, zanurzonej w miejski kontekst. Kwestionując ludzka dominację oraz brak podmiotowości i sprawczości zwierząt, tym samym dokonywalibyśmy głębokiej korekty naszego - siłą rzeczy antropocentrycznego-sposobu myślenia o mieście. Zbliżalibyśmy się do przekształcenia Metropolis w Zoopolis, przestrzeń w równym stopniu przyjaznq dla ludzi oraz dla zwierząt i innych podmiotów nie-ludzkich.

dr hab. Piotr Krupiński, prof. US 